\title{
Volatility Shocks and Investment Behavior
}

\author{
Christoph Huber ${ }^{1}$, Jürgen Huber ${ }^{2}$, and Michael Kirchler ${ }^{\dagger} 2$ \\ ${ }^{1}$ Institute for Markets and Strategy, WU Vienna University of Economics and Business, \\ Welthandelsplatz 1, 1020 Vienna, Austria \\ ${ }^{2}$ Department of Banking and Finance, University of Innsbruck, \\ Universitätsstrasse 15, 6020 Innsbruck, Austria
}

November 27, 2021

\begin{abstract}
We investigate how volatility shocks affect investors' risk-taking, risk perception and forecasts. We run artefactual field experiments with two participant pools (finance professionals and students), differing in (i) the direction of the shock (down, up, or a neutral case) and (ii) the presentation format of the time series (prices or returns). Professionals' investments are negatively associated with the price change and performance of the stock and their perceived risk increases to a similar extent following shocks of all directions. Students' risk perception, in contrast, is more closely related to the frequency of negative returns rather than an increase in volatility.
\end{abstract}

JEL: C91, G11, G41

Keywords: Risk taking, risk perception, experimental finance, finance professionals, volatility shocks

We thank Christian König-Kersting, Michel Maréchal, Elise Payzan-LeNestour, and Matthias Stefan for comments on previous versions of this paper. Financial support from the Austrian Science Fund FWF (P29362-G27 J. Huber, STARTgrant Y617-G11 Kirchler, and SFB F63) is gratefully acknowledged. The pre-registration for this study following the AsPredicted.org protocol can be found under this DOI: 10.17605/OSF.IO/W87KT. The experimental software, data, and replication materials are posted on the Open Science Framework (OSF): osf.io/9chg8. This study was ethically approved by the Institutional Review Board at the University of Innsbruck.

${ }^{\dagger}$ Email addresses: christoph.huber@wu.ac.at (C. Huber), juergen.huber@uibk.ac.at (J. Huber), michael.kirchler@uibk.ac.at (M. Kirchler). 


\section{Introduction}

Nassim Nicolas Taleb (2007) famously coined the term "black swan" to describe rare and unpredictable outlier events, which have an extreme impact. Applied to financial markets, such tail events, such as a major crash, can wipe out years of accumulated returns and can influence people's beliefs, perceptions, and behavior for a long time (e.g., Cogley \& Sargent, 2008; Graham \& Narasimhan, 2005; Guiso et al., 2018; Malmendier \& Nagel, 2011). It is indeed the big price surges and crashes that most vividly come to mind when thinking of financial markets; these events can have long-lasting effects on the outcome of an investment, as it may take years to make up a substantial loss, for instance. Often, mainstream finance theory, however, assumes stationary, normally distributed asset returns (e.g., Black \& Scholes, 1973, in the context of option pricing). This is at odds with empirical observation. First, return distributions are leptokurtic, i.e., they have "fat tails" as tail events occur considerably more often than a normal distribution would suggest. And, second, return volatility (the standard deviation of returns) varies over time as "normal," tranquil times are interrupted by high-volatility clusters (e.g., Andersen \& Bollerslev, 1997; Alizadeh et al., 2002; Mandelbrot \& Hudson, 2008): ${ }^{1}$ Negative tail events are often followed by positive tail events and together constitute periods of high volatility on financial markets. ${ }^{2}$

In this study we investigate investors' reactions to volatility shocks-i.e., to changes in an asset's underlying return distribution (a shift in volatility, in particular). Our approach differs from previous, related work by inducing shocks to asset return volatility, in contrast to shocks to one asset returns, as is common in investment experiments. We thus incorporate periods of high volatility, which are characterized by very high (positive and negative) returns. In a novel experimental setup applying a $2 \times 3$ factorial treatment design, we vary the presentation format (returns or prices) and the "direction" of the shock (mostly positive returns, mostly negative returns, or a neutral case). Hence, we examine whether and how different types of volatility shocks affect how investors (i) take risk, (ii) perceive risk, and (iii) forecast prices and returns.

\footnotetext{
${ }^{1}$ In addition to empirical research, a number of theoretical models applying time-varying volatility have appeared. Heston (1993), for example, provides a stochastic volatility model in the context of option pricing.

${ }^{2}$ To illustrate this proposition, consider the S\&P 500 stock index in the last six decades. The largest daily returns in this time period all occurred after the index suffered record-high losses on the previous days. The S\&P 500 surged by $9.10 \%$ on October 21,1987 after having lost $20.5 \%$ two days earlier; it surged by $11.6 \%$ on October 13,2008 after having lost $1.2 \%$ and $7.6 \%$ in the two previous days; and it surged by $9.3 \%$ on March 13, 2021 after having lost $9.5 \%$ and $4.9 \%$ on the two previous days, only to drop by another $12.0 \%$ on March 16 .
} 
Consider investment decisions, i.e., how much risk investors take, first. Classical finance theory suggests that an investor's optimal allocation between risky and risk-free assets is determined by her individual risk attitude (Tobin, 1958; Merton, 1969; Samuelson, 1969). With stable risk attitudes over time, an increase in an asset's risk—defined as an increase in volatility—should ceteris paribus lead to a decrease in risk-taking and vice versa.

More recent contributions postulate that an investor's risk-taking is a function not only of her risk attitude and the asset's volatility, but also of her perceived risk and her expected return (see Nosić \& Weber, 2010, for example). ${ }^{3}$ Crucially, investors' risk perception is not necessarily related to the variance of returns, but is rather driven by the frequency of negative returns (Holzmeister et al., 2020; Zeisberger, 2020); a characteristic which can lead to over-pessimistic decisions when investors evaluate their portfolios frequently (myopic loss aversion; see Benartzi \& Thaler, 1995; Thaler et al., 1997). Following this intuition, a volatility shock would only affect risk-taking when it comes with a drop or a surge in returns, such that investors update their beliefs about the probability of positive/negative returns and, in turn, also their risk perception. In a related fashion, Corgnet et al. (2020) demonstrate that, under both Expected Utility Theory (with limited liability) and Prospect Theory, investors who suffer losses due to a negative tail event increase their bids for a risky asset. With respect to the present study, these results would translate into investors increasing their risk-taking following a negative volatility shock and potentially decreasing their risk-taking following a positive volatility shock.

Besides an investor's risk attitude and her perceived risk, her future expected asset return is also a natural candidate in determining investment behavior. How do investors update their beliefs when faced with a volatility shock that comes with mostly positive returns, mostly negative returns, or a net-zero development? We conjecture that volatility per se does not affect investor's point predictions of future asset returns. Rather, investors would adapt to realized prices, and a sudden increase or decrease thus drives their expectations up or down, respectively. In comparing presentation formats—-showing returns and eliciting return forecasts vs. showing prices and eliciting price forecasts—, previous studies suggest higher responses when asking for return forecasts (e.g., Glaser et al., 2019).

\footnotetext{
${ }^{3}$ Nosić \& Weber (2010) decompose an investment decision as Risk Taking = $f$ (Perceived Return, Risk Attitude, Risk Perception). Holzmeister et al. (2021) also provide a critical discussion on how the inter-relationship between risk attitude, risk-taking, and risk perception is conceptualized in experimental finance.
} 
Taking all such factors into consideration, we propose a novel experimental setup to address the following research questions:

RQ1(a). Does a change in a stock's underlying return distribution (a shock to volatility) affect participants' investment behavior?

RQ1(b). Does a change in a stock's underlying return distribution (a shock to volatility) affect participants' perceptions about a stock's risk?

$R Q 1$ (c). Does a change in a stock's underlying return distribution (a shock to volatility) affect participants' expectations about its future price/return development?

RQ2. Do the behavioral patterns observed in RQ1 depend on the particular nature of the shock, i.e., whether a surge in volatility comes along with a price downturn, a price upturn, or with a price development where the net return is close to zero?

RQ3. Do the behavioral patterns observed in RQ1 depend on the presentation format, i.e., whether the stock development is presented as a return bar chart or as a price chart?

RQ4. Are there systematic differences between finance professionals and students on RQ1 to RQ3?

We recruit 202 finance professionals, predominantly working as portfolio and investment managers, financial advisors, and traders, as well as 282 students to participate. During the experiment, all participants are confronted with a series of portfolio decisions in an environment that is characterized by changes in the underlying return distribution with shifts (shocks) in volatility. Participants are sequentially presented with 100 daily returns of a risky stock, whose returns are based on historical data. Every 0.5 seconds, one return is realized and is added to the price or return chart. Every 20 return draws, i.e., five times in total, participants decide which percentage of their experimental wealth to invest in the risky stock, with the remainder being held in cash. In addition, we elicit participants' satisfaction, their beliefs about future prices or returns, and how risky they perceive the stock to be. To induce volatility shocks, one of the five periods consist of returns drawn from a different distribution with considerably higher volatility (i.e., from a volatility cluster in the historical data). In a $2 \times 3$ factorial treatment design, we vary the presentation format (returns or prices) and the "direction" of the shock (mostly positive returns, mostly negative returns, or a neutral case) to address our research questions. Experiments are uniquely 
well-suited for this purpose, as they allow for the direct observation of behavior and beliefs when inducing a volatility shock, while controlling all available information.

We find that finance professionals and students exhibit, for the most part, qualitatively similar reactions to volatility shocks, but also show some important differences. First, we show that investment propensity is negatively associated with the direction of the shock, and that students tend to invest less in general. Second, we observe that finance professionals' and students' investment satisfaction is positively correlated with the direction of the shock. Third, we find that finance professionals perceive all induced volatility shocks (no matter whether prices move up, down, or remain almost unchanged) to increase perceived risk to a similar extent. This differs from the students' results, as students perceive upward-trending shocks not to increase the stock's riskiness. Finally, whereas professionals do not show differences in forecasts between presentation formats, students exhibit more extreme price forecasts in the returns condition following net-zero and upward shocks.

With this study, we contribute to a number of research strands in financial decision-making. First, by exposing not only laypeople, but also highly experienced finance professionals to the experience of volatility shocks, we address the often-raised question of the external validity of finance experiments, which are usually mostly conducted with students. Especially to understand financial decision making, financial professionals are the most relevant subject pool. With out results we add to the growing body of research on professionals' investment behavior, risk assessments, and return expectations (see e.g., Haigh \& List, 2005; Glaser et al., 2007; Kaustia \& Knüpfer, 2008; Cohn et al., 2015; Kirchler et al., 2018; Huber et al., 2019; Holzmeister et al., 2020; Weitzel et al., 2020).

Second, this study relates to findings on the impact of the display format (showing returns or prices) and the framing of investment decisions in general. In a series of experiments with both students, general population samples, and finance professionals, Grosshans \& Zeisberger (2018) and Schwaiger et al. (2019) demonstrate that the sequence of returns-i.e., the shape of a price path—has a systematic effect on investors' satisfaction. Participants prefer an initial downturn with a subsequent price increase (down-up stocks) to an initial surge with a subsequent price decrease (up-down stocks), given identical prices at the end. Moreover, Borsboom \& Zeisberger 
(2020) identify salient features, such as a price paths' highs and lows, as well as short-term crashes as main drivers of risk perception and, in turn, of investment decisions.

A number of related studies addressing framing effects also compare return and price representations in charts and find that asking for return forecasts as opposed to price forecasts results in higher expectations, whereas showing participants historical returns instead of historical prices yields lower expectations (Glaser et al., 2007, 2019). With respect to the present study-analyzing investment behavior and beliefs after negative or positive shocks-one might expect differential effects for different presentation formats, as different characteristics are salient in return bar charts compared to price line charts. We extend this line of literature by analyzing behavioral reactions to crashes in combination with charts that develop over time in a dynamic environment. Hence, in our approach, we show how "experiencing" a crash or a positive shock (prominent examples include stock price reactions after earnings announcements, among others) changes investment behavior of finance professionals and laypeople (e.g., students).

Through this way of "experiencing" we also touch the literature on "learning from experience" (Hertwig et al., 2004). Comparing decisions from descriptions and decisions from experience, previous work identifies a description-experience gap in risky choice situations (for an overview, see Hertwig \& Erev, 2009). In the context of financial investment decisions, Bradbury et al. (2015) show that simulated experience-i.e., sampling a number of returns from a given distributionimproves people's calibration regarding a stock's risk and their investment decisions compared to decisions purely based on description. We extend this literature to a more commonly occurring setting in financial markets, where the underlying return distribution is not known exactly and is subject to random, unexpected shocks. In contrast to "experience-sampling" from a known distribution, we thus let investors in the experiment "experience" a distribution over time by revealing financial returns sequentially as a time series of either returns or prices.

In our setting ambiguity prevails, and this might be perceived differently by professionals and students, especially if the former believe they can identify the financial time series. The presence of ambiguity in stock markets is often associated with higher levels of volatility (Dow \& da Costa Werlang, 1992; Epstein \& Wang, 1994), hence, one can argue that our design features ambiguity and volatility shocks. Recently, Kostopoulos et al. (2021) show that investors respond to ambiguity shocks by reducing risk-taking. We add to this literature by showing that especially 
financial professional react differently, depending on whether a shock overall leads to higher or lower prices.

Finally, we contribute to the growing literature on volatility and risk perception as outcome variables. ${ }^{4}$ Huber \& Huber (2019), Holzmeister et al. (2020), and Zeisberger (2020), for example, find that investors perceive return distributions as more risky when the probability of a loss is higher (while a higher variance in the underlying distributions does not play a major role). In particular, while we replicate previous findings on financial professionals and lay people of Holzmeister et al. (2020)-i.e., for whom a negative return or the probability of a loss tend to be driving risk perception-we also find differences. The authors report that professionals' and lay people's risk perception does not vary with volatility (i.e., the standard deviation of returns). We extend this line of literature by showing that professionals indeed associate shocks in volatility with higher perceived risk. The differences between our study and the one of Holzmeister et al. (2020), however, could potentially be driven by the different experimental frameworks. ${ }^{5}$

Considering portfolio allocations, Ehm et al. (2014) report that people tend to suffer from an inabilitity to adapt their portfolios to different volatilities between stocks, i.e., they invest similar percentages into a risky stock regardless of the given return volatilities. However, the closest study to ours with regard to inducing volatility as a stimulus is the one by Payzan-LeNestour et al. (2016). The authors explore "variance after-effects," exposing participants to either low-variance or high-variance trajectories of a stock market index, which is represented as a dynamically moving line plot. They observe that perceived volatility is smaller after exposure to high volatility and vice versa, and propose variance as constituting an independent cognitive property distinct from sensory effects, which can distort risk perception. Similarly, making use of the neuroscience theory of efficient coding, Payzan-LeNestour et al. (2021) find that people systematically underestimate risk after prolonged exposure to high risk, as they seem to get accustomed to high volatility and consider it "normal." We contribute to this line of literature in a different experimental framework

\footnotetext{
${ }^{4}$ In recent years, a number of studies have looked into framing effects in risk perception and financial decisionmaking analysing, among other things, presenting return charts vs. presenting price charts; e.g., Weber et al. (2005), Diacon \& Hasseldine (2007), Kaufmann et al. (2013), Ehm et al. (2014), and Huber \& Huber (2019).

${ }^{5}$ The experimental frameworks differ in important aspects, as Holzmeister et al. (2020) show histograms of the return distribution of an asset, while in our study—as in real financial markets-participants do not know the distribution of the risky asset's returns ex ante and we present price and return charts dynamically evolving over time. Hence, for future research and for the comparison of studies, it is important to distinguish whether one considers a dynamic or static setting and whether the return distribution is known/visible or unknown, leading to ambiguity in the latter case. See also a recent study by Corgnet et al. (2021), which shows that presenting information statically vs. dynamically in a forecasting task engages different cognitive skills.
} 
in a financial markets setting, examining situations with changing volatilities within a stock's historical returns. Importantly, our experimental design also allows one to distinguish investment behavior (i.e., risk taking) from risk perception as well as from price and return expectations.

\section{The Experiment}

\subsection{The Investment Task}

In a controlled online experiment with a sample of financial professionals and a standard student sample, we sequentially present 100 daily returns of a risky stock, whose returns are based on historical data from the NASDAQ and DAX indices. Every 0.5 seconds, one of the 100 returns is realized and is added either to a return bar chart or to a price line chart, depending on the treatment. We model the volatility shock in the following way: DOWN, UP, and STRAIGHT refer to a downwardtrending shock, an upward-trending shock, and a net-zero shock, respectively. The DowN-shock is either the NASDAQ-crash from April to May of 2000 or the DAX-crash from September to October of 2008, the UP-shock contains the mirrored returns from the DOWN-shock, ${ }^{6}$ and STRAIGHT contains a sample of returns from UP- and DOWN-returns selected to minimize the total period's absolute return with the same standard deviation as in the other two shock paths. ${ }^{7}$ Returns in non-shock periods are taken from more tranquil times from the same index as the respective shock. Using two distinct time series for each of the three shocks (based on either NASDAQ or DAX returns) mitigates the risk of artifacts affecting our results and thus increases internal validity. All time series presented as price and return charts are shown in Figure B1 and Figure B2 in Online Appendix B.

Figure 1 shows the return distributions of the tranquil and turbulent periods for the three different shock (treatment) conditions (DOWN, STRAIGHT, UP), respectively. Figure 2 shows the representative sequence of action for one of the Down time series. In all time series we model a pre-shock

\footnotetext{
${ }^{6}$ Naturally occurring examples of comparable UP-shocks on financial markets can be found in price developments after earnings announcements that exceed expectations or major technological breakthroughs, for example (e.g., the stocks of Tesla, an electric vehicle company, surged by $39.2 \%$ in one month after exceeding analysts expectations in October 2019, and the stocks of CureVac, a company developing vaccines against COVID-19, more than doubled in November 2020 after reporting successful results from a Phase I-II clinical trial.)

${ }^{7}$ The standard deviation of returns is 0.93 percent in non-shock periods vs. 4.99 percent in shock periods. This five-fold increase in volatility is comparable to recent extreme shocks on financial markets but also in line with more commonly occurring events. The своЕ Volatility Index (VIX) increased almost six-fold in March 2020, more than fourfold in October 2008, but also saw similar developments in August 2011, August 2015, and February 2018, for example.
} 
phase in periods 1 and 2, the shock in the third period, and a post-shock phase in periods 4 and

5.
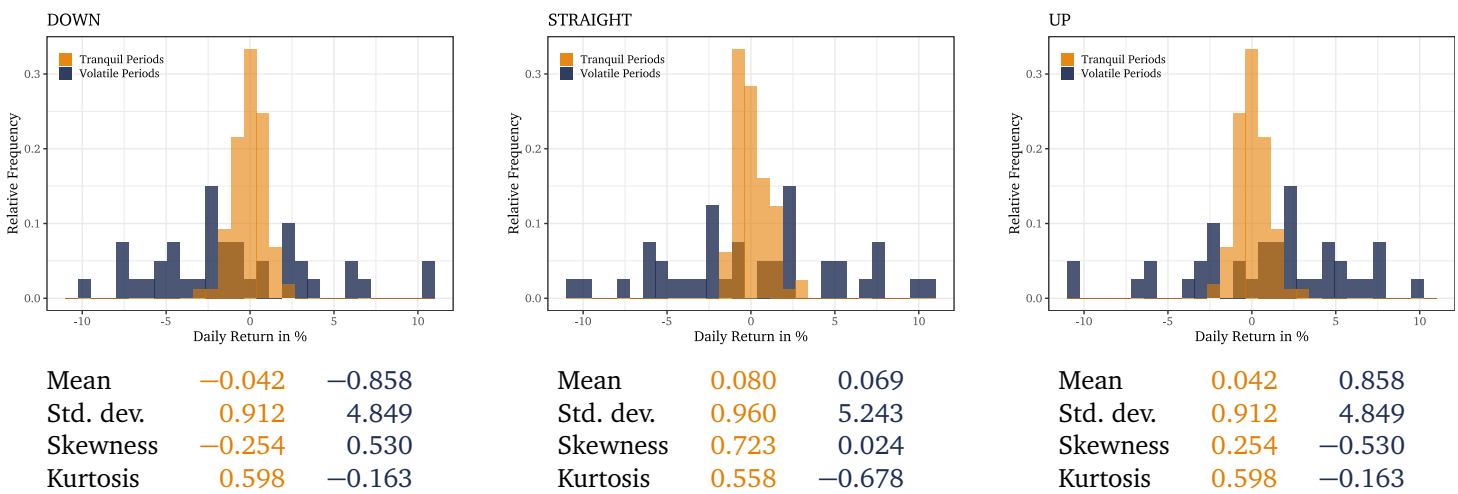

Figure 1: Daily returns in shock and non-shock periods across treatments: This figure shows histograms of the time series' daily returns used in the experiment for all three treatments. The returns from the volatile periods (blue) represent the shock period (period 3), and the returns from the calm (tranquil) periods (orange) were used in the periods preceding and following the shock. Below each histogram we show the corresponding mean and standard deviation (in percent) as well as skewness and kurtosis parameters for each distribution of daily returns.

Every 20 return draws (every 20 trading days, referred to as one trading month in the experiment), i.e., five times in total, participants have to make a number of decisions, allowing us to elicit the following variables (also see the experimental instructions in Online Appendix A for further details): ${ }^{8}$

- InVEstment: Percentage invested in the (risky) stock ("What percentage of your wealth do you want to invest in the risky stock in the next month?" [from $0 \%$ to $100 \%$ ]).

- Recommendation: Trading recommendation for the stock ("If you were an analyst, would your recommendation for the stock be SELL, HOLD or BUY?" [Likert scale ranging from "strong sell" (1) to "strong buy" (5)]).

- SATISFACTION: Satisfaction with the stock ("Please state your satisfaction with the stock on a scale ranging from -3 to 3 , where -3 indicates 'very unsatisfied' and 3 indicates 'very satisfied." ").

\footnotetext{
${ }^{8}$ In the experiment, we also elicited participant's optimistic and pessimistic forecast for the stock price (e.g., "What is your optimistic/pessimistic estimate for the price at the end of the next month? (only in $5 \%$ of cases the actual price will be above/below this price)") for price or return predictions. To keep the paper short and concise, we report results for the recommendations and for the difference between a participant's optimistic and pessimistic forecasts in the Online Appendix only.
} 
- RISK PERCEPTION: Perception of the stock's risk ("How risky do you perceive this stock on the basis of its past returns?" [Likert scale ranging from "not risky at all" (1) to "very risky" (7)]).

- PRICE FORECAST ("What is your estimate of the most likely price at the end of next month?" [only if prices are displayed]).

- RETURN FORECAST ("What is your estimate of the most likely monthly return in the next month?" [only if returns are displayed]).

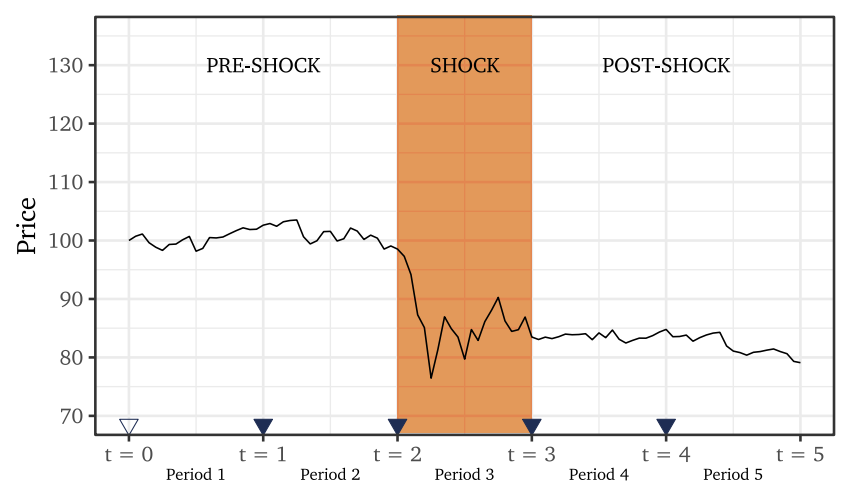

Figure 2: Sample sequence of action in one of the experimental time series used. The pre-shock period is the time up to $t=2$, the shock happens in period 3, and the post-shock phase runs from periods 4 to 5 . At $t=1, t=2, t=3$, and $t=4$, participants had to answer a number of questions in addition to deciding which percentage of their endowment to invest in the risky stock; at $t=0$, participants only decide which percentage of their endowment to invest.

\subsection{Treatments}

In a $2 \times 3$ design, we vary the "presentation format" (RETURNS or PRICES) and the "shock" of the stock (mostly negative returns, mostly positive returns, or net-zero returns during the shock). In a between-subjects design, participants are randomly assigned to one of two presentation format conditions: participants are either presented with price line charts or with return bar charts. In addition, we randomly vary the second treatment variable, the underlying shock (DOWN, STRAIGHT, or UP), within subjects. Thus, each participant experiences all three paths (either in the return or the price chart condition) but in a random order. We restricted this randomization in order to avoid learning by participants seeing mirror-images of the same time series; i.e., if a participant is 
presented with the DOWN-series based on NASDAQ data, then she is presented with the UP-series based on DAX data, and vice versa.

Table 1: Between- and within-participants treatment structure with a $2 \times 3$ factorial design. The treatment variable "presentation format" was implemented such that participants were either presented with charts composed of PRICES or RETURNS. The treatment variable "shock" (DOWN, STRAIGHT, and UP) was implemented within-participants such that each participant experienced all three paths (either in the return or the price chart condition) but in a randomized order.

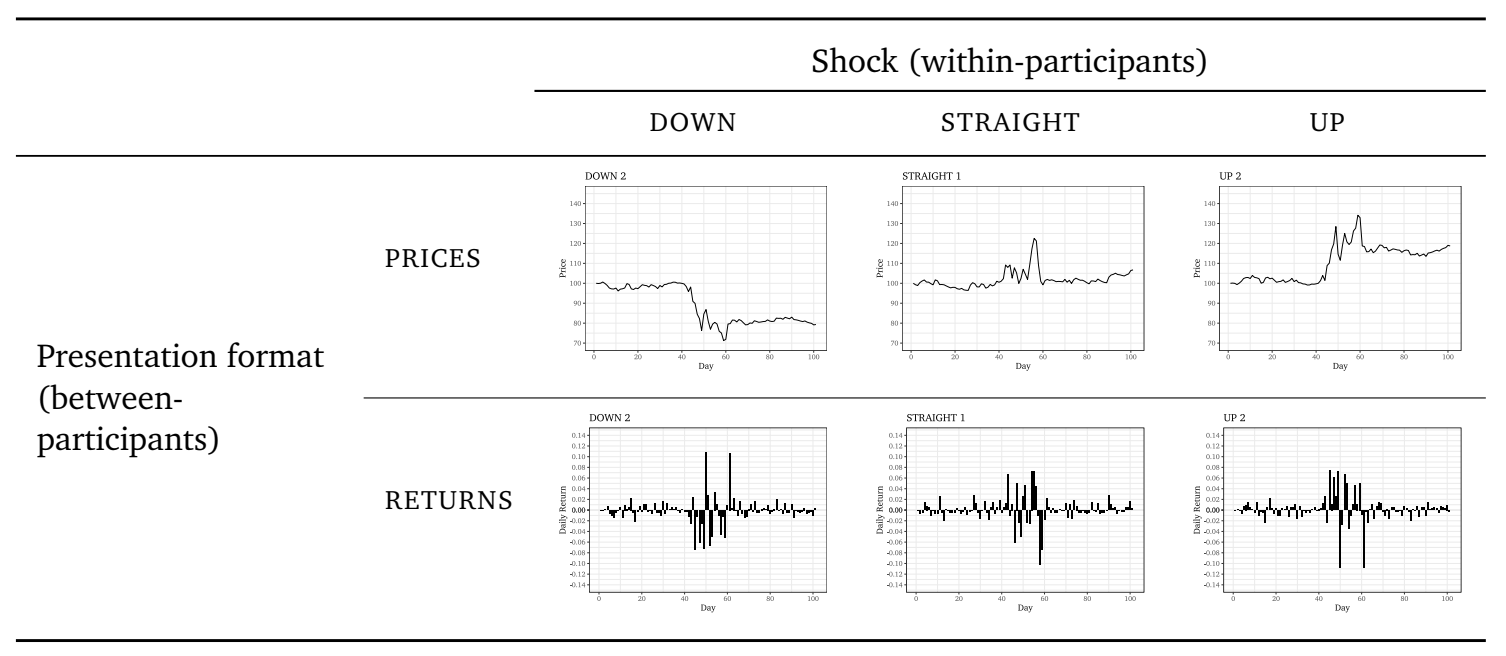

Summing up the sequence of the experiment, each participant is presented with all three shock paths, DOWN, STRAIGHT, and UP, of the same presentation format in random order. In each path (i.e., for each stock), 100 returns are revealed over time, each lasting for 0.5 seconds, with decisions to make after every 20 price/return draws. Consequently, each participant makes five decisions per stock and, thus, 15 decisions overall. For a treatment overview, see Table 1.

\subsection{Experimental Procedure}

We invited financial professionals from before.world, some of whom have already participated in different types of lab-in-the-field or online experiments (e.g., Kirchler et al., 2018; Schwaiger et al., 2019; Weitzel et al., 2020). In total, 202 financial professionals completed the experiment. Table $\mathrm{C} 1$ in the Online Appendix outlines demographic information and job functions of the experimental participants. On average, professionals were 37.9 years of age at the time of the experiment $(S D=8.5)$, the fraction of female participants among all professionals was 12.9 percent, and the fraction of professionals with a university degree was 89.6 percent. Moreover, approximately 30 percent of professionals selected investment- or portfolio management as their primary job 
description, followed by financial advice, and trading. In addition, 282 economics and business students from the Innsbruck EconLab's participant pool at the University of Innsbruck, recruited with hroot (Bock et al., 2014), completed the experiment.

After the main experiment, we elicited participants' general and financial risk attitudes with two survey questions from the German Socio-Economic Panel (GSoEP; see Dohmen et al., 2011), their cognitive reflection abilities using two (not well-known) cognitive reflection test (CRT) questions from Toplak et al. (2014), and a number of demographics (age, gender, education, profession). Table C1 in the Online Appendix outlines that professionals answered 1.38 CRT questions correctly, which is 0.32 questions more than students (Mann-Whitney $U$-test, $N=484, p<0.005$ ). Moreover, professionals' self-reported general and financial risk tolerances were significantly higher than the ones reported by students (General: 6.6 (professionals) vs. 5.7 (students), Mann-Whitney $U$-test, $N=484, p<0.005$; Financial: 6.8 vs. 4.5 , Mann Whitney $U$-test, $N=484, p<0.005$ ). At the end of the experiment, one of the five periods (i.e., investment decisions) from one of the three paths was randomly selected for payment. A participant's percentage return from this randomly selected period multiplied by 3 was added to an endowment of EUR 20 for professionals. ${ }^{9}$ Student participants' endowment was EUR 5. Financial professionals earned on average EUR 20.47 with a standard deviation of EUR 4.00 (5.45 and 0.84 for students, respectively) and minimum and maximum payments of EUR 8 and EUR 32 ( 2 and 8 for students). The median duration of the experiment was 20.4 minutes for professionals and 19.4 minutes for students.

About three months after we conducted this experiment, in March 2020, the COVID-19 pandemic unfolded and led to stock markets crashing around the world. We took the opportunity to repeat this experiment and to run a second wave with the identical experimental protocol but with a new sample of 113 finance professionals and 216 students from the same participant pools. In Huber et al. (2021), a companion paper to the present study, we examine how the experience of extreme events affects risk-taking behavior by investigating potential level-effects between the first wave conducted in December 2019 and reported in this study (WAVE 1 in the companion paper),

\footnotetext{
${ }^{9}$ That is, if a participant invested $70 \%$ of her wealth in the risky stock in the randomly selected month and the stock's return in this month was $15 \%$, then the return from this month was $70 \% \times 15 \%=10.5 \%$. The payment from the experiment was EUR $20 \times(1+10.5 \% \times 3)=$ EUR 26.30 . Any money not invested generated neither profits nor losses, equivalent to a savings account with $0 \%$ interest. As overnight interest rates on deposits from households in the Euro area have been below $0.10 \%$ since 2016 , we apply comparable $0 \%$ interest in the experiment for simplicity. We decided to only incentivize the investment task, as most of the other tasks cannot easily be incentivized in a similar way (e.g., RISK PERCEPTION, RECOMMENDATION, SATISFACTION).
} 
and the second wave conducted in March 2020 during the naturally occurring stock market crash (WAVE 2). In Section 4, below, we briefly report on some results of WAVE 2, which acts a replication of our initial results, and we refer to Huber et al. (2021) for further details. ${ }^{10}$

\section{Results}

The results section is structured as follows. First, we examine how volatility shocks in the experiment affect both professionals' and students' investment behavior as well as related variables, i.e., INVESTMENT, SATISFACTION, and RECOMMENDATION. Next, we look into the respective shocks' effects on how participants perceive risk (RISK PERCEPTION); finally, we look into how people's beliefs about future prices and returns are affected (PRICE FORECAST and RETURN FORECAST).

For each variable, we plot fitted values from ordinary least squares regressions with period dummies for $t \in\{2,3,4\}$ for the presentation formats RETURNS and PRICES, the experimental shocks DOWN, STRAIGHT, and UP, and the respective interaction terms. The experimental shock always occurred during period 3 . We denote $t \in\{2,3,4\}$ in the regressions and figures as the end of the respective period, at which point participants entered their decisions (see Figure 2). $t=2$ thus refers to the last decision before the shock, $t=3$ refers to the first decision after the shock.

In addition, we run ordinary least squares regression analyses for each participant pool (financial professionals and students) and for both presentation formats (RETURNS and PRICES) separately, and we measure differences in the dependent variables (INVESTMENT, SATISFACTION, RECOMMENDATION, RISK PERCEPTION, PRICE FORECAST, and RETURN FORECAST) before and after the volatility shock. In particular, we run the following regression model(s):

$$
\begin{aligned}
y_{i, t}=\beta_{0} & +\beta_{1} \text { POST_SHOCK }+\beta_{2} \text { PRE_SHOCK } \times \text { DOWN }+\beta_{3} \text { POST_SHOCK } \times \text { DOWN } \\
& +\beta_{4} \text { PRE_SHOCK } \times \text { UP }+\beta_{5} \text { POST_SHOCK } \times \text { UP. } .
\end{aligned}
$$

Here, $y_{i, t}$ is a generic placeholder representing the respective dependent variable described above for participant $i$ in period $t$. POST_SHOCK is a dummy variable taking the value 1 for periods after

\footnotetext{
${ }^{10}$ Huber et al. (2021) report results comparing finance professionals' investment behavior and risk perception in WAVE 2 in March 2020 relative to WAVE 1 in December 2019, while the present study is concerned with how experimental volatility shocks affect investment behavior and beliefs. The analyses in this study are distinct from and complementary to those in Huber et al. (2021); there is no direct overlap in the reported results.
} 
the volatility shock (i.e., decisions at $t=3$ and $t=4$ ), zero otherwise, and PRE_SHOCK denotes a dummy variable taking the value 1 for periods before the shock (i.e., decisions at $t=0, t=1$, and $t=2$ for InVESTMENT, and decisions at $t=1$ and $t=2$ for all other variables), zero otherwise. The interaction terms (e.g., POST_SHOCK $\times$ UP) measure the combined effects of the shock phase (i.e., before or after the shock) and the respective treatment (i.e., UP or DOWN). Hence, the effects of treatment STRAIGHT are incorporated in the dummy POST_SHOCK for decisions at $t=3$ and $t=4$ after the shock and can directly be compared to the pre-shock decisions at $t=0, t=1$ and $t=2$ in treatment STRAIGHT, measured with the constant. The pre- and post-shock effects of the other treatments are measured through the interaction terms. Moreover, we run all specifications with control variables such as a participant's risk attitude, CRT score, age, and gender. We cluster standard errors at the participant level and apply a 0.5\%- and 5\%-significance level, respectively, following Benjamin et al. (2018). We also run a number of additional model specifications with separate regressions for each path and binary dummy variables for each presentation format (PRICES and RETURNS) as outlined in the pre-registration (DOI:10.17605/OSF.IO/W87KT); as well as specifications only considering the first occurrence of each within-subjects treatment. ${ }^{11}$ The respective results are identical in their qualitative nature but provide some additional insights about potentially differential effects when presenting return or price charts. To keep the paper focused and concise, we present these supplementary analyses in the Online Appendix but refer to the relevant figures when discussing the respective results in the main text.

\subsection{Investment Behavior}

We examine investment behavior first, for which Figure 3 and Table 2 show our main results. Figure 3 presents fitted values from regressions with period dummies for the presentation formats RETURNS (triangles) and PRICES (dots), and the shocks DOWN (blue), STRAIGHT (orange), and UP (red). ${ }^{12}$ Table 2 shows the regression estimates with binary pre- and post-shock variables for each participant pool and each presentation format separately.

\footnotetext{
${ }^{11}$ Note that estimating analogous random effects models produces almost identical results than the ordinary results estimates reported in this study; detailed results are available upon request.

${ }^{12}$ See also Figures B6 to B9 in the Online Appendix that outline more detailed time trends for all variables. The corresponding regression models with coefficient estimates and standard errors are provided in Tables C4 through C6 in the Online Appendix. For the fitted values presented in Figure 3, we use the specifications including all covariates.
} 
Result 1: Finance professionals' investment levels are negatively associated with the direction of the experimental shock. Students, in comparison, show lower investment levels in general, and change their investment behavior following the experimental shocks to a smaller degree.

Support: Professionals' fraction invested in the stock increases (decreases) statistically significantly after a negative (positive) experimental shock in both presentation formats. In particular, professionals invest between 5.0 and 6.5 percentage points more in the stock following a downward shock, and between 5.9 and 7.7 percentage points less following an upward shock, compared to the investment levels after a straight shock (see the first row in Figure 3 and columns 1 and 2 of Table 2, $p<0.005)$.

Result 1 points to a behavioral pattern that is in line with the disposition effect (Odean, 1998), indicating that professionals have a stronger preference for realizing winning rather than losing stocks. This also is consistent with a belief in mean reversion of prices, in line with Shefrin \& Statman (1985) and Jiao (2017), for example.

Students, in contrast, do not change their investment behavior following a downward shock, but reduce their invested fraction statistically significantly following an upward shock in both presentation formats by 3.2 to 4.5 percentage points, compared to the levels in the condition STRAIGHT (see the first row in Figure 3 and columns 7 and 8 of Table 2, $p<0.05$ ).

Importantly, we find no substantial differences in post-shock reactions between presentation formats, i.e., between presenting return bar charts and price line charts. While investment levels with RETURNS tend to be slightly above those with PRICES, this difference in post-shock investments is only statistically significant for finance professionals in Treatment Down (see Table C18 in the Online Appendix).

Our data also allow us to distinguish between investors' reactions, depending on how severely they were affected by the shock in terms of their wealth, following the framework put forward in a recent study by Corgnet et al. (2020) to examine investors' reactions to negative tail events. There, they demonstrate that, under Expected Utility Theory (with limited liability) and Prospect Theory, investors who observe but do not suffer a tail event are more likely to reduce their auction bids for a risky asset, while those who suffer a tail event and thereby incur substantial losses subsequently increase their bids. As an exploratory test for this proposition, we compare participants' changes 
PROF: Investment

Fitted values before $(t=2)$ and after $(t>2)$ the shock

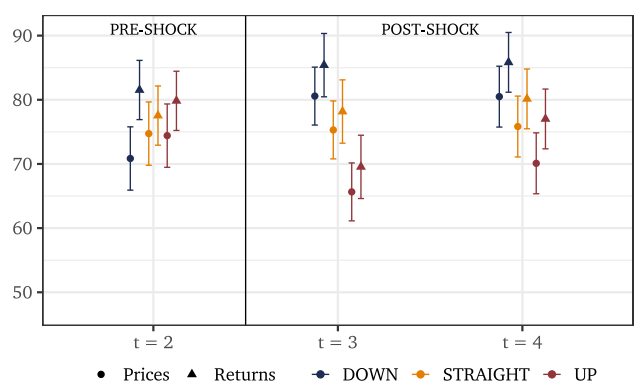

PROF: Recommendation

Fitted values before $(t=2)$ and after $(t>2)$ the shock

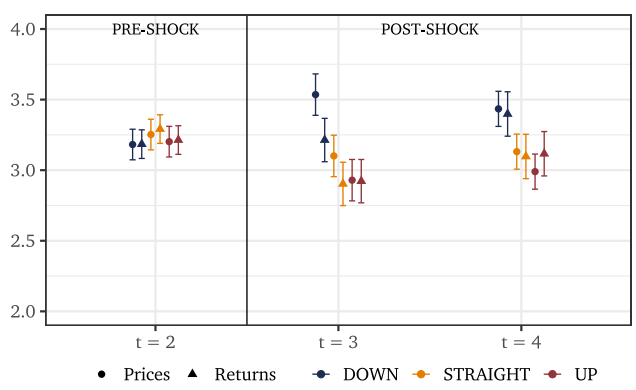

PROF: Satisfaction

Fitted values before $(t=2)$ and after $(t>2)$ the shock

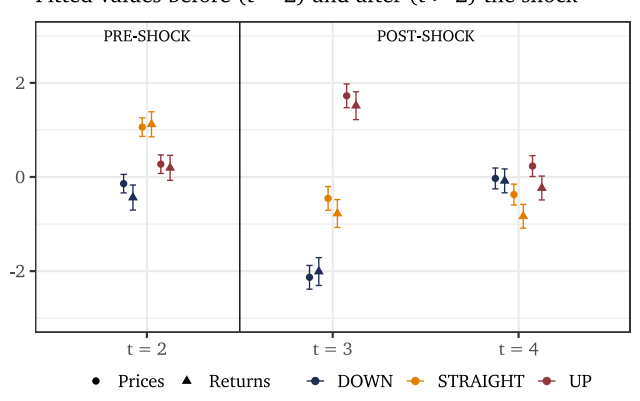

STUD: Investment

Fitted values before $(t=2)$ and after $(t>2)$ the shock

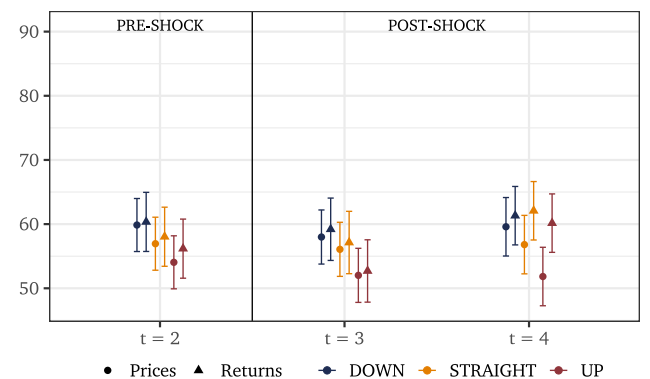

STUD: Recommendation

Fitted values before $(t=2)$ and $\operatorname{after}(t>2)$ the shock

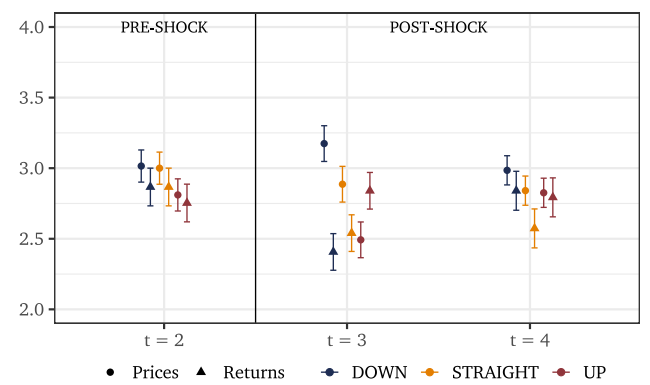

STUD: Satisfaction

Fitted values before $(t=2)$ and after $(t>2)$ the shock

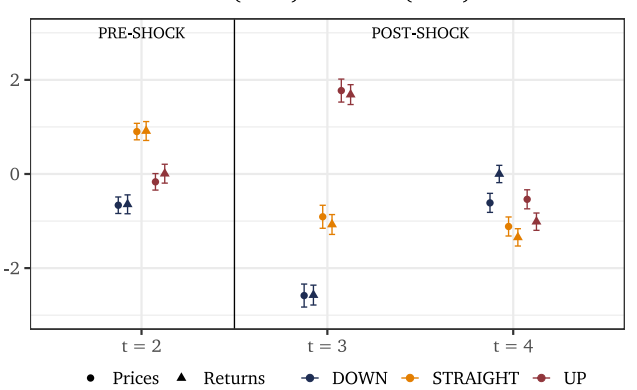

Figure 3: Fitted values of investment, recommendation, and satisfaction before $(t=2)$, at $(t=3)$, and one period after the shock $(t=4)$ for both presentation formats RETURNS (triangles) and PRICES (dots) and the shock types UP (blue), DOWN (red), and STRAIGHT (green). The corresponding regression models with coefficient estimates and standard errors are provided in Tables C4 through C6 in the Online Appendix. Fitted values are calculated, including all covariates. Return forecasts are converted into price forecasts for better comparability. The whiskers indicate the $95 \%$ confidence intervals. 
Table 2: Ordinary least squares regressions on INVESTMENT, RECOMMENDATION, and SATISFACTION, for each participant pool (financial professionals and students) and each presentation format (RETURNS or PRICES). POST_SHOCK is a dummy variable taking the value 1 for periods after the volatility shock (i.e., $t=3$ and $t=4$ ), zero otherwise, and PRE_SHOCK stands for a dummy variable taking the value 1 for periods before the shock (i.e., $t=1$ and $t=2$ ), zero otherwise. The interaction terms (e.g., POST_SHOCK $\times$ UP) measure the combined effects of the shock phase (i.e., before or after the shock) and the respective treatment (i.e., UP or DOWN). All specifications are run with a participant's risk attitude, CRT score, age, and gender as control variables. Estimates only considering the first occurrence of each shock-treatment and estimates with and without controls are shown in Table C2 and Tables C11 to C13, respectively, in the Online Appendix. Clustered standard errors at the participant-level are in parentheses. ${ }^{*}$ and ${ }^{* *}$ indicate the $5 \%$ - and $0.5 \%$-significance levels, respectively.

\begin{tabular}{|c|c|c|c|c|c|c|}
\hline \multirow[b]{2}{*}{ Finance Professionals } & \multicolumn{2}{|c|}{ Investment } & \multicolumn{2}{|c|}{ Recommendation } & \multicolumn{2}{|c|}{ Satisfaction } \\
\hline & $\begin{array}{l}\text { Prices } \\
\text { (1) }\end{array}$ & $\begin{array}{l}\text { Returns } \\
\text { (2) }\end{array}$ & $\begin{array}{l}\text { Prices } \\
\text { (3) }\end{array}$ & $\begin{array}{l}\text { Returns } \\
\text { (4) }\end{array}$ & $\begin{array}{l}\text { Prices } \\
\text { (5) }\end{array}$ & $\begin{array}{l}\text { Returns } \\
\text { (6) }\end{array}$ \\
\hline POST_SHOCK & $\begin{array}{c}0.630 \\
(1.395)\end{array}$ & $\begin{array}{c}1.015 \\
(1.415)\end{array}$ & $\begin{array}{c}-0.106 \\
(0.062)\end{array}$ & $\begin{array}{c}-0.204^{* *} \\
(0.070)\end{array}$ & $\begin{array}{c}-0.490^{* *} \\
(0.075)\end{array}$ & $\begin{array}{c}-0.899^{* *} \\
(0.117)\end{array}$ \\
\hline PRE_SHOCK $\times$ DOWN & $\begin{array}{c}-3.381 \\
(1.881)\end{array}$ & $\begin{array}{c}2.061 \\
(1.343)\end{array}$ & $\begin{array}{c}-0.020 \\
(0.052)\end{array}$ & $\begin{array}{c}0.029 \\
(0.045)\end{array}$ & $\begin{array}{c}-0.061 \\
(0.069)\end{array}$ & $\begin{array}{r}-0.147 \\
(0.080)\end{array}$ \\
\hline POST_SHOCK $\times$ DOWN & $\begin{array}{c}4.966^{* *} \\
(1.690)\end{array}$ & $\begin{array}{c}6.462^{* *} \\
(1.909)\end{array}$ & $\begin{array}{c}0.369^{* *} \\
(0.076)\end{array}$ & $\begin{array}{c}0.306^{* *} \\
(0.084)\end{array}$ & $\begin{array}{c}-0.673^{* *} \\
(0.094)\end{array}$ & $\begin{array}{r}-0.245^{*} \\
(0.113)\end{array}$ \\
\hline PRE_SHOCK $\times$ UP & $\begin{array}{c}0.581 \\
(1.479)\end{array}$ & $\begin{array}{c}2.421 \\
(1.555)\end{array}$ & $\begin{array}{c}-0.035 \\
(0.048)\end{array}$ & $\begin{array}{c}-0.019 \\
(0.051)\end{array}$ & $\begin{array}{c}0.086 \\
(0.061)\end{array}$ & $\begin{array}{r}-0.099 \\
(0.086)\end{array}$ \\
\hline POST_SHOCK $\times$ UP & $\begin{array}{c}-7.694^{* *} \\
(2.392)\end{array}$ & $\begin{array}{r}-5.874^{*} \\
(2.247)\end{array}$ & $\begin{array}{r}-0.157^{*} \\
(0.073)\end{array}$ & $\begin{array}{c}0.019 \\
(0.092)\end{array}$ & $\begin{array}{c}1.390^{* *} \\
(0.117)\end{array}$ & $\begin{array}{c}1.450^{* *} \\
(0.129)\end{array}$ \\
\hline Constant & $\begin{array}{c}36.104^{*} \\
(15.213)\end{array}$ & $\begin{array}{c}58.334^{* *} \\
(16.907)\end{array}$ & $\begin{array}{c}3.106^{* *} \\
(0.262)\end{array}$ & $\begin{array}{c}3.063^{* *} \\
(0.279)\end{array}$ & $\begin{array}{c}-0.660 \\
(0.521)\end{array}$ & $\begin{array}{c}0.628 \\
(0.523)\end{array}$ \\
\hline Controls & Yes & Yes & Yes & Yes & Yes & Yes \\
\hline Observations & 1,485 & 1,545 & 1,188 & 1,236 & 1,186 & 1,227 \\
\hline $\mathrm{R}^{2}$ & 0.178 & 0.123 & 0.070 & 0.050 & 0.173 & 0.115 \\
\hline Adjusted $\mathrm{R}^{2}$ & 0.172 & 0.117 & 0.062 & 0.042 & 0.165 & 0.108 \\
\hline Students & (7) & (8) & (9) & (10) & (11) & (12) \\
\hline POST_SHOCK & $\begin{array}{c}0.988 \\
(1.287)\end{array}$ & $\begin{array}{c}0.542 \\
(1.325)\end{array}$ & $\begin{array}{r}-0.144^{*} \\
(0.060)\end{array}$ & $\begin{array}{c}-0.240^{* *} \\
(0.064)\end{array}$ & $\begin{array}{c}-0.738^{* *} \\
(0.096)\end{array}$ & $\begin{array}{c}-0.929^{* *} \\
(0.080)\end{array}$ \\
\hline PRE_SHOCK $\times$ DOWN & $\begin{array}{c}2.844 \\
(1.457)\end{array}$ & $\begin{array}{c}0.351 \\
(1.451)\end{array}$ & $\begin{array}{c}-0.008 \\
(0.059)\end{array}$ & $\begin{array}{c}0.030 \\
(0.053)\end{array}$ & $\begin{array}{c}-0.161 \\
(0.082)\end{array}$ & $\begin{array}{c}-0.264^{* *} \\
(0.085)\end{array}$ \\
\hline POST_SHOCK $\times$ DOWN & $\begin{array}{c}2.350 \\
(1.949)\end{array}$ & $\begin{array}{c}0.651 \\
(1.635)\end{array}$ & $\begin{array}{c}0.216^{* *} \\
(0.072)\end{array}$ & $\begin{array}{c}0.067 \\
(0.067)\end{array}$ & $\begin{array}{c}-0.587^{* *} \\
(0.098)\end{array}$ & $\begin{array}{r}-0.077 \\
(0.083)\end{array}$ \\
\hline PRE_SHOCK $\times$ UP & $\begin{array}{c}0.190 \\
(1.649)\end{array}$ & $\begin{array}{c}-1.945 \\
(1.459)\end{array}$ & $\begin{array}{c}-0.095 \\
(0.059)\end{array}$ & $\begin{array}{c}0.027 \\
(0.056)\end{array}$ & $\begin{array}{c}-0.037 \\
(0.091)\end{array}$ & $\begin{array}{c}-0.044 \\
(0.065)\end{array}$ \\
\hline POST_SHOCK $\times$ UP & $\begin{array}{r}-4.514^{*} \\
(2.028)\end{array}$ & $\begin{array}{r}-3.180^{*} \\
(1.592)\end{array}$ & $\begin{array}{r}-0.205^{*} \\
(0.075)\end{array}$ & $\begin{array}{c}0.260^{* *} \\
(0.075)\end{array}$ & $\begin{array}{c}1.629^{* *} \\
(0.130)\end{array}$ & $\begin{array}{c}1.533^{* *} \\
(0.100)\end{array}$ \\
\hline Constant & $\begin{array}{c}13.916 \\
(13.977)\end{array}$ & $\begin{array}{c}41.026^{*} \\
(17.081)\end{array}$ & $\begin{array}{c}2.761^{* *} \\
(0.167)\end{array}$ & $\begin{array}{c}2.551^{* *} \\
(0.308)\end{array}$ & $\begin{array}{c}-0.911^{*} \\
(0.371)\end{array}$ & $\begin{array}{c}-0.501 \\
(0.476)\end{array}$ \\
\hline Controls & Yes & Yes & Yes & Yes & Yes & Yes \\
\hline Observations & 1,980 & 2,250 & 1,584 & 1,800 & 1,580 & 1,794 \\
\hline $\mathrm{R}^{2}$ & 0.168 & 0.141 & 0.037 & 0.031 & 0.167 & 0.107 \\
\hline Adjusted $\mathrm{R}^{2}$ & 0.164 & 0.137 & 0.031 & 0.026 & 0.161 & 0.102 \\
\hline
\end{tabular}


in investments in $t=3$ (i.e., directly after the volatility shock) between those with below-median losses and those with above-median losses in Treatment Down, and between those with belowmedian gains and those with above-median gains in Treatment UP. As we can see from Figure 4, in line with Corgnet et al.'s (2020) results for negative tail events, participants who suffered more severe losses during the DOWN-crash indeed increased their risk-taking, as they subsequently invested roughly 10 percentage points more in the risky asset $(p<0.01, N=202$ for PROF and $N=282$ for STUD, two-sided $t$-tests for each subject pool). Moreover, with our experimental setup we can run analogue analyses for reactions to price surges in UP: here, we find that those who experience above-median gains significantly decrease their investments compared to those with below-median gains ( $p<0.01$, two-sided $t$-tests for each subject pool). Thus, Prospect Theory is suitable to explain increased risk taking after negative shocks and decreased risk taking after positive shocks in our setting.
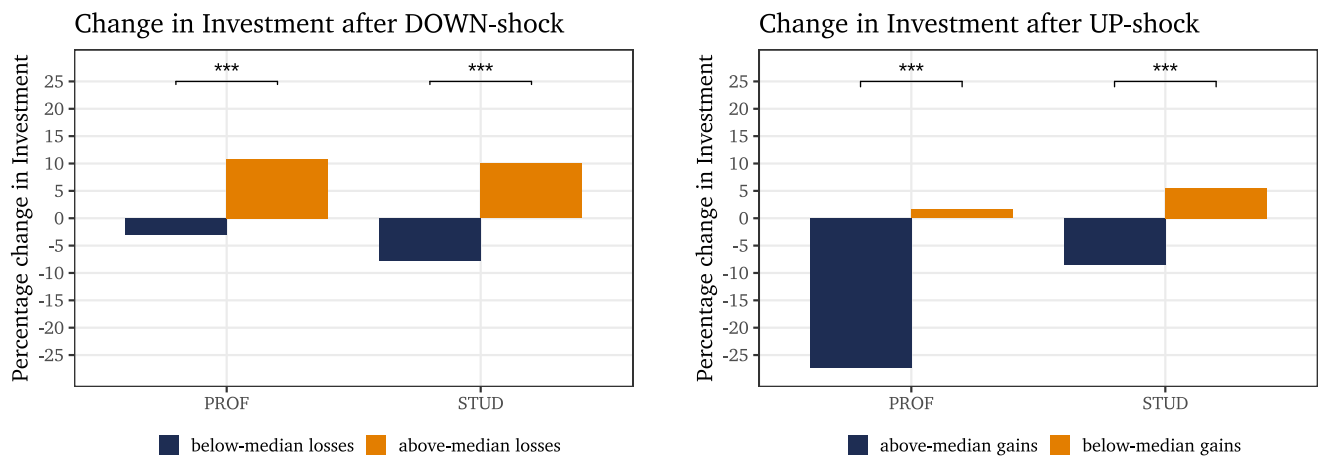

Figure 4: Change in INVESTMENT in $t=3$ (i.e., directly after the volatility shock) in treatments DOWN (left panel) and UP (right panel) across subject pools (PROF and STUD), depending on above- and below-median losses and gains, respectively. Median losses after a DowN-shock were $13.2 \%$; median gains after an UP shock were $9.28 \%$.

As a closely related variable to participants' own investment levels, we also examine their respective trading recommendations for other participants on a scale commonly used by analysts, ranging from "strong sell" (1) to "strong buy" (5). One can easily see from the second row of Figure 3 and columns 3 and 4 of Table 2 that, on average, the positions participants recommend correlate with their own investment behavior: as professionals increase their investment directly after a negative price shock, they also tend to shift their recommendation upwards towards recommending to "buy" and vice versa. Note, however, that, on average, professionals in our sample tend to recommend comparatively more risk-averse behavior after the shock: while they shift 
their recommendations towards "buy" after a downward shock and towards "sell" after an upward shock, they also move towards a "sell" recommendation in the neutral, net-zero shock-in contrast to their own investment behavior. This suggests a "cautious shift," i.e., more risk aversion when investing for others than when investing for oneself, which has also been found in the loss domain of risky gambles (e.g., Zhang et al., 2017). Also note that finance professionals, in particular, appear to be averse to directional recommendations for others, as most of these analyst recommendations are at or very close to recommending no positional change-that is, they tend to give a "hold" recommendation. More generally, these results relate to risky decision-making for others and to financial advice, in particular. ${ }^{13}$

Next, we examine how the induced volatility shocks affect investors' satisfaction. Grosshans \& Zeisberger (2018) and Schwaiger et al. (2019) report that price paths with up- and down-swings have a profound effect on satisfaction levels, a variable that might be an important factor in explaining subsequent investment decisions. Results are presented in the last row of Figure 3 and in columns 5 and 6 of Table 2.

Result 2: Finance professionals' investment satisfaction is positively correlated with the direction of the experimental shock, but drops to pre-shock levels in the final period. Students show qualitatively similar results.

Support: Professionals' satisfaction levels drop significantly after a downward shock (even after a shock of the category STRAIGHT) and increase significantly after an upward shock (see Figure 3 and columns 5 and 6 of Table 2; $p<0.05$ for return charts in Down, $p<0.005$ for all other treatments). For instance, compared to the pre-shock treatment phase, satisfaction levels drop by approximately 1.2 points (on the 7-point Likert scale) following a downward shock and increase by close to 1 point after an upward shock. Also note that satisfaction levels significantly decrease between 0.5 and 0.9 points in STRAIGHT (i.e., with increasing volatility but close to net-zero returns), suggesting that a surge in volatility decreases participants satisfaction levels although their wealth is not affected. One could argue that volatility, and, more generally, uncertainty, make participants feel uneasy and evoke discomfort even without monetary consequences. Moreover, we show that shifts in satisfaction are short-term, as satisfaction reaches approximately pre-shock lev-

\footnotetext{
${ }^{13}$ Polman \& Wu (2020) provide a recent review and meta-analysis of the literature on decision-making for others in risky choices.
} 
els again in $t=4$. These findings similarly hold for both presentation formats and for the student sample (see Table C20 in the Online Appendix).

\subsection{Risk Perception}

Next to participants' investment behavior, we are interested in whether their risk perception shifts in light of the experimental shocks. Huber \& Huber (2019), Holzmeister et al. (2020), and Zeisberger (2020) show that, in abstract settings, investor risk perception is correlated with the probability of a loss rather than with volatility per se. This leads us to expect an increase in risk perception only after a downward price shock (DOWN) but not after prices have increased (UP) or remained constant (STRAIGHT). Related to this notion, we conjecture that risk perception is differentially affected by shocks with different presentation formats: in return charts, volatility is very salient while the price change is not; in price charts, volatility is less salient while the price change is very prominent. Hence, we expect a potential effect of losses in the shock-period on participants' risk perception to be larger for price chart representations.

Result 3: Finance professionals perceive all volatility shocks in the experiment (i.e., DOWN, STRAIGHT, or UP) to increase risk similarly, independent of the presentation format. Students show partly similar patterns, but do not perceive an upward price or return shock to increase the riskiness of the stock.

Support: None of the interaction terms of the post-shock phase with the direction of the shock (DOWN, STRAIGHT, or UP) among finance professionals are statistically significant, pointing at no difference in risk perception between different directions of the experimental shock. Compared to pre-shock levels of risk perception, the experimental shocks increase risk perception by approximately one point on the 7-point Likert scale in all treatments $(p<0.005$, see the first row in Figure 5 and columns 1 and 2 in Table 3). However, students show different levels of risk perception of the stock in a downward shock. Columns 7 and 8 in Table 3 indicate a statistically significantly lower (higher) risk perception of an upward (downward) shock in both presentation formats and in both waves compared to straight shocks ( $p<0.005$ for prices, $p<0.05$ for returns). Thus, it seems that financial professionals' training and experience brings their risk assessments more in line with theory, which, measuring risk as volatility/standard deviation, detects volatility clusters 
as increasing volatility, irrespective of whether the overall price change is positive, negative, or close to zero.

Notably, we also report that participants' reactions to shocks of different types (directions) hold similarly for price and return charts in both participant pools, i.e., for finance professionals as well as for students (see the interaction term POST_SHOCK $\times$ RETURNS, testing for differences after the shock between the presentation formats in Table C21 in the Online Appendix).

\subsection{Price and Return Forecasts}

Finally, we look into how participants' expectations about future prices and returns adapt to the severe volatility shocks in the experiment. Results are presented in the second and third row of Figure 5 and in columns 3 to 6 of Table 3. Note that participants in treatment RETURNS were asked about future returns only, and participants in treatment PRICES where asked about future prices only. For consistency and comparability, we convert all forecasts to expectations about both returns and prices.

Result 4: Finance professionals' price forecasts are in the direction of the experimental shock and do not systematically differ between the presentation formats. Students exhibit similar patterns, but show more extreme predictions when returns are presented.

Support: We find that finance professionals exhibit significantly higher (lower) price forecasts after an upward (downward) experimental shock compared to price shocks, without clear directional movement of type STRAIGHT. In particular, professionals' price predictions following an upward shock are 15.3 higher than in the treatment with net-zero shocks, and 13.9 lower in the case of downward shocks when presenting price charts $(p<0.005$; the respective values when presenting return charts are 15.7 and 16.8). Note that prices actually change by +16.0 with an upward shock and -17.6 with a downward shock. Thus, price expectations adapt well to changes in realized prices, but they under-react mildly in the downward case. A belief in (and hope for) a mean reversion of prices may be the most important factor for these predictions, also leading to increasing investments after a negative shock (and decreasing investments after a positive shock); see Figure 5 and columns 3 to 6 of Table 3. 
PROF: Risk perception

Fitted values before $(t=2)$ and after $(t>2)$ the shock

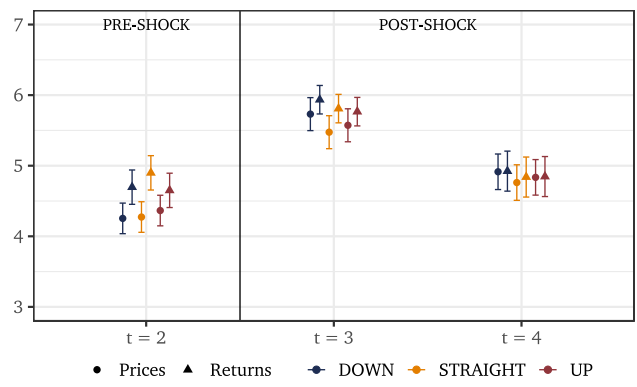

PROF: Price Forecast

Fitted values before $(t=2)$ and after $(t>2)$ the shock

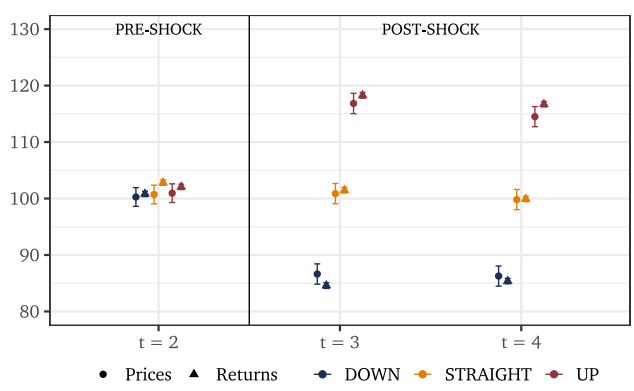

PROF: Return Forecast

Fitted values before $(t=2)$ and after $(t>2)$ the shock

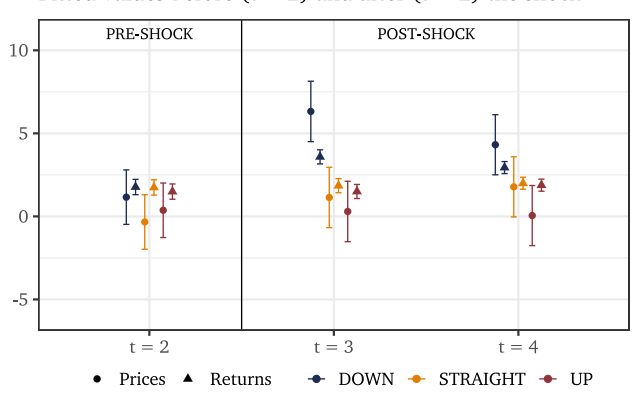

STUD: Risk perception

Fitted values before $(t=2)$ and after $(t>2)$ the shock

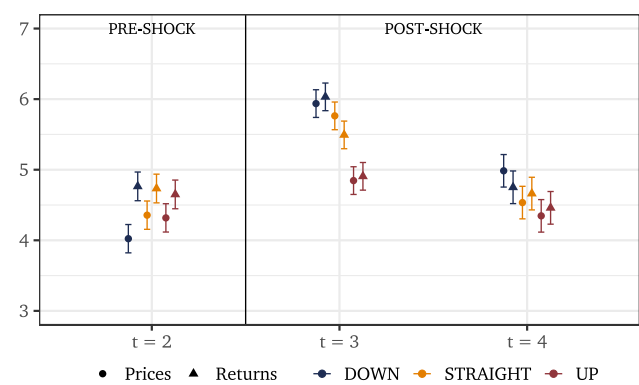

STUD: Price Forecast

Fitted values before $(t=2)$ and after $(t>2)$ the shock

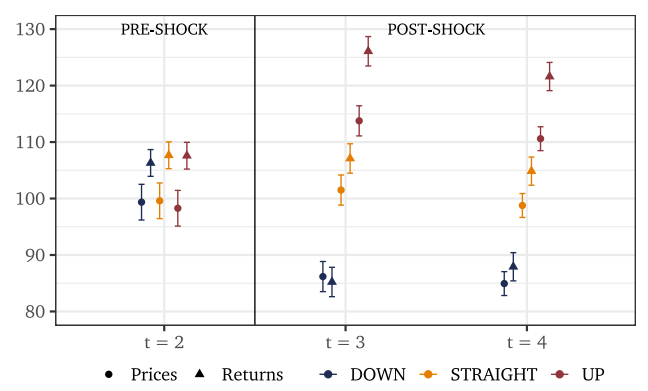

STUD: Return Forecast

Fitted values before $(t=2)$ and after $(t>2)$ the shock

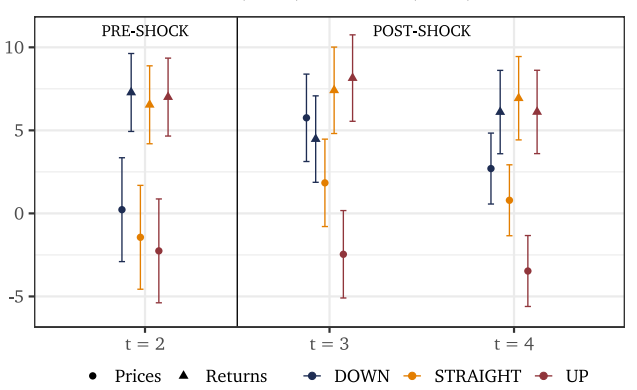

Figure 5: Fitted values of risk perception and price and return forecasts before $(t=2)$, at $(t=3)$, and one period after the shock $(t=4)$ for both presentation formats RETURNS (triangles) and PRICES (dots) and the shock types UP (blue), DOWN (red), and STRAIGHT (green). The corresponding regression models with coefficient estimates and standard errors are provided in Tables C7 through C9 in the Online Appendix. Fitted values are calculated, including all covariates. Return forecasts are converted into price forecasts for better comparability. The whiskers indicate the $95 \%$ confidence intervals. 
Table 3: Ordinary least squares regressions on RISK PERCEPTION, PRICE FORECAST, and RETURN FORECAST, for each participant pool (financial professionals and students) and each presentation format (RETURNS or PRICES). POST_SHOCK is a dummy variable taking the value 1 for periods after the volatility shock (i.e., $t=3$ and $t=4$ ), zero otherwise, and PRE_SHOCK stands for a dummy variable taking the value 1 for periods before the shock (i.e., $t=1$ and $t=2$ ), zero otherwise. The interaction terms (e.g., POST_SHOCK $\times$ UP) measure the combined effects of the shock phase (i.e., before or after the shock) and the respective treatment (i.e., UP or Down). All specifications are run with a participant's risk attitude, CRT score, age, and gender as control variables. Estimates only considering the first occurrence of each shock-treatment and estimates with and without controls are shown in Table C3 and Tables C14 to C16, respectively, in the Online Appendix. Clustered standard errors at the participant-level are in parentheses. ${ }^{*}$ and ${ }^{* *}$ indicate the $5 \%$ - and $0.5 \%$-significance levels, respectively.

\begin{tabular}{|c|c|c|c|c|c|c|}
\hline \multirow[b]{2}{*}{ Finance Professionals } & \multicolumn{2}{|c|}{ Risk perception } & \multicolumn{2}{|c|}{ Price forecast } & \multicolumn{2}{|c|}{ Return forecast } \\
\hline & $\begin{array}{l}\text { Prices } \\
\text { (1) }\end{array}$ & $\begin{array}{l}\text { Returns } \\
\text { (2) }\end{array}$ & $\begin{array}{l}\text { Prices } \\
\text { (3) }\end{array}$ & $\begin{array}{l}\text { Returns } \\
\text { (4) }\end{array}$ & $\begin{array}{l}\text { Prices } \\
\text { (5) }\end{array}$ & $\begin{array}{l}\text { Returns } \\
\text { (6) }\end{array}$ \\
\hline POST_SHOCK & $\begin{array}{c}0.868^{* *} \\
(0.085)\end{array}$ & $\begin{array}{c}0.518^{* *} \\
(0.101)\end{array}$ & $\begin{array}{c}1.415 \\
(0.724)\end{array}$ & $\begin{array}{c}-0.161 \\
(0.237)\end{array}$ & $\begin{array}{c}1.697^{*} \\
(0.729)\end{array}$ & $\begin{array}{c}0.211 \\
(0.186)\end{array}$ \\
\hline PRE_SHOCK $\times$ DOWN & $\begin{array}{c}-0.064 \\
(0.096)\end{array}$ & $\begin{array}{c}-0.158 \\
(0.113)\end{array}$ & $\begin{array}{c}1.006 \\
(0.874)\end{array}$ & $\begin{array}{c}0.721^{* *} \\
(0.166)\end{array}$ & $\begin{array}{c}0.448 \\
(0.881)\end{array}$ & $\begin{array}{c}0.044 \\
(0.141)\end{array}$ \\
\hline POST_SHOCK $\times$ DOWN & $\begin{array}{c}0.204 \\
(0.110)\end{array}$ & $\begin{array}{c}0.094 \\
(0.099)\end{array}$ & $\begin{array}{c}-13.892^{* *} \\
(1.460)\end{array}$ & $\begin{array}{r}-15.722^{* *} \\
(0.389)\end{array}$ & $\begin{array}{c}3.858^{*} \\
(1.550)\end{array}$ & $\begin{array}{c}1.341^{* *} \\
(0.331)\end{array}$ \\
\hline PRE_SHOCK $\times$ UP & $\begin{array}{c}0.126 \\
(0.092)\end{array}$ & $\begin{array}{c}-0.113 \\
(0.098)\end{array}$ & $\begin{array}{c}1.632 \\
(1.204)\end{array}$ & $\begin{array}{c}0.589^{* *} \\
(0.164)\end{array}$ & $\begin{array}{c}0.891 \\
(1.231)\end{array}$ & $\begin{array}{c}-0.211 \\
(0.151)\end{array}$ \\
\hline POST_SHOCK $\times$ UP & $\begin{array}{c}0.085 \\
(0.092)\end{array}$ & $\begin{array}{c}-0.026 \\
(0.104)\end{array}$ & $\begin{array}{c}15.325^{* *} \\
(0.837)\end{array}$ & $\begin{array}{c}16.785^{* *} \\
(0.338)\end{array}$ & $\begin{array}{c}-1.286 \\
(0.691)\end{array}$ & $\begin{array}{c}-0.232 \\
(0.222)\end{array}$ \\
\hline Constant & $\begin{array}{c}2.676^{* *} \\
(0.569)\end{array}$ & $\begin{array}{c}4.387^{* *} \\
(0.636)\end{array}$ & $\begin{array}{l}99.350^{* *} \\
(3.420)\end{array}$ & $\begin{array}{c}98.732^{* *} \\
(0.990)\end{array}$ & $\begin{array}{c}0.439 \\
(3.492)\end{array}$ & $\begin{array}{c}0.044 \\
(0.995)\end{array}$ \\
\hline Controls & Yes & Yes & Yes & Yes & Yes & Yes \\
\hline $\begin{array}{l}\text { Observations } \\
\mathrm{R}^{2}\end{array}$ & $\begin{array}{l}1,172 \\
0.181\end{array}$ & $\begin{array}{l}1,220 \\
0.096\end{array}$ & $\begin{array}{l}1,188 \\
0.345\end{array}$ & $\begin{array}{l}1,236 \\
0.906\end{array}$ & $\begin{array}{l}1,188 \\
0.063\end{array}$ & $\begin{array}{l}1,236 \\
0.087\end{array}$ \\
\hline Adjusted $\mathrm{R}^{2}$ & 0.174 & 0.089 & 0.340 & 0.905 & 0.055 & 0.080 \\
\hline Students & (7) & (8) & (9) & (10) & (11) & (12) \\
\hline POST_SHOCK & $\begin{array}{c}0.683^{* *} \\
(0.093)\end{array}$ & $\begin{array}{c}0.183^{*} \\
(0.088)\end{array}$ & $\begin{array}{c}1.681^{*} \\
(0.741)\end{array}$ & $\begin{array}{c}-0.0003 \\
(0.455)\end{array}$ & $\begin{array}{c}2.019^{*} \\
(0.747)\end{array}$ & $\begin{array}{c}0.300 \\
(0.437)\end{array}$ \\
\hline PRE_SHOCK $\times$ DOWN & $\begin{array}{c}-0.432^{* *} \\
(0.114)\end{array}$ & $\begin{array}{r}-0.183^{*} \\
(0.083)\end{array}$ & $\begin{array}{c}0.984 \\
(1.140)\end{array}$ & $\begin{array}{c}1.081 \\
(0.678)\end{array}$ & $\begin{array}{c}0.423 \\
(1.142)\end{array}$ & $\begin{array}{c}0.390 \\
(0.673)\end{array}$ \\
\hline POST_SHOCK $\times$ DOWN & $\begin{array}{c}0.310^{* *} \\
(0.098)\end{array}$ & $\begin{array}{c}0.310^{* *} \\
(0.090)\end{array}$ & $\begin{array}{c}-14.575^{* *} \\
(1.039)\end{array}$ & $\begin{array}{c}-19.406^{* *} \\
(0.620)\end{array}$ & $\begin{array}{r}2.913^{*} \\
(1.069)\end{array}$ & $\begin{array}{c}-1.885^{\text {** }} \\
(0.576)\end{array}$ \\
\hline PRE_SHOCK $\times$ UP & $\begin{array}{c}-0.154 \\
(0.110)\end{array}$ & $\begin{array}{c}-0.171 \\
(0.089)\end{array}$ & $\begin{array}{c}-0.558 \\
(0.972)\end{array}$ & $\begin{array}{c}0.478 \\
(0.473)\end{array}$ & $\begin{array}{c}-1.362 \\
(0.981)\end{array}$ & $\begin{array}{c}-0.401 \\
(0.470)\end{array}$ \\
\hline POST_SHOCK $\times$ UP & $\begin{array}{c}-0.551^{* *} \\
(0.111)\end{array}$ & $\begin{array}{c}-0.396^{* *} \\
(0.099)\end{array}$ & $\begin{array}{l}12.042^{* *} \\
(1.115)\end{array}$ & $\begin{array}{l}17.867^{* *} \\
(0.584)\end{array}$ & $\begin{array}{c}-4.280^{* *} \\
(0.997)\end{array}$ & $\begin{array}{c}-0.045 \\
(0.516)\end{array}$ \\
\hline Constant & $\begin{array}{c}4.188^{* *} \\
(0.683)\end{array}$ & $\begin{array}{c}4.199^{* *} \\
(0.563)\end{array}$ & $\begin{array}{l}93.048^{* *} \\
(8.098)\end{array}$ & $\begin{array}{c}119.501^{* *} \\
(9.964)\end{array}$ & $\begin{array}{c}-5.751 \\
(8.203)\end{array}$ & $\begin{array}{c}20.459^{*} \\
(10.113)\end{array}$ \\
\hline Controls & Yes & Yes & Yes & Yes & Yes & Yes \\
\hline Observations & 1,560 & 1,776 & 1,584 & 1,800 & 1,584 & 1,800 \\
\hline $\mathrm{R}^{2}$ & 0.123 & 0.043 & 0.238 & 0.354 & 0.063 & 0.064 \\
\hline Adjusted $\mathrm{R}^{2}$ & 0.118 & 0.037 & 0.234 & 0.350 & 0.057 & 0.059 \\
\hline
\end{tabular}


Moreover, we show in Table C22 in the Online Appendix that professionals' reactions to shocks of different types do not differ between the presentation formats. Students, however, do exhibit differences in forecasts between prices and returns. Although the forecast patterns following upward and downward shocks are qualitatively similar to what we observe with professionals, students show more extreme behavior in the presentation format RETURNS. In $t=2$, before the induced shock, predictions from return charts are significantly above those from price charts. While predictions from return charts do not move much after a downward shock, those from price charts increase significantly. Moreover, forecasts are significantly higher with returns than with prices after straight and upward shocks ( $p<0.005$, see Table C22 in the Online Appendix). This is largely in line with Glaser et al. (2007), who report higher (lower) forecasts in upward- (downward-) sloping time series when asking about future returns instead of asking about future prices. More generally, we corroborate the findings by Glaser et al. (2019) that asking for return forecasts as opposed to price forecasts results in higher expectations. ${ }^{14}$

\section{Robustness and Replication: Evidence from WAVE 2}

As stated in Section 2, we replicated the experiment in March 2020, at the peak of the COVID-19 stock market crash, and we briefly report on results from this WAVE 2 here. In the realm of the present study, this second wave, in principle, acts as a direct replication (Schmidt, 2009) of the original study, which we employ as an additional robustness check for the results and treatment differences reported above. This is a valuable exercise as the particular effects identified in this study could be a result of, for instance, the particular time period during which we conducted the experiment (see Nosek \& Errington, 2020, for example): a tranquil, "bullish" boom period on financial markets. Risk taking (e.g., Cohn et al., 2015), risk perception (e.g., Payzan-LeNestour et al., 2021), but also participants' expectations have been shown to adapt and to be distorted when faced with more volatile, "bearish" bust markets.

Figures B10 and B11 as well as Tables C32 and C33 in the Online Appendix mirror the analyses discussed above, with the new data from WAVE 2. Overall, we largely replicate our initial results of

\footnotetext{
${ }^{14}$ Note that Glaser et al. (2019) also report that showing return charts leads to lower expectations in contrast to showing price charts. In the current study, we ask about returns when showing returns and ask about prices when showing prices. Treading carefully, one could interpret our result of higher expectations with returns as the "task effect" (asking for return/price forecasts) being stronger than the "stimuli effect" (showing return/price charts) in this particular framework.
} 
WAVE $1 .{ }^{15}$ With regard to participants' investment behavior, we find finance professionals to invest approximately 5 percentage points more in the experimental stock following a downward shock compared to following a straight shock in WAVE 1 ; the corresponding increase in WAVE 2 is 10 percentage points. If at all, participants' reactions to the volatility shocks in the investment game thus appear to be larger in the second wave. Students, however, only reduce their investments following an upward shock by 3.2 to 3.4 percentage points compared to the net-zero shock, but this finding is only statistically significant in WAVE 1 . Next, consider investor satisfaction in WAVE 2 . As in the original experiment, unsurprisingly both students and finance professionals become more (less) satisfied after an upward (downward) shock.

Examining participants' perception of the risky asset, our WAVE 2 results confirm the findings from above: the experimental shocks increase professionals' risk perception by approximately one point regardless of the presentation format and regardless of the direction of the price change. Students, however, lower their risk perception following an upward shock and increase it following a downward shock. Lastly, expectation adaptions following experimental shocks are also very similar between WAVE 1 and WAVE 2. Professionals' price forecasts are strongly correlated with the realized price change in all treatments but under-react mildly after downward shocks. For students, we observe qualitatively similar patterns but an over-reaction to shocks when presenting return charts.

Thus, we conclude that the behavioral patterns observed with experimental shocks appear to be robust, both for the finance professionals and the students.

\section{Conclusion}

In this study, we presented results from a novel artefactual field experiment with 202 finance professionals and 282 students from economics and business to investigate participants' reactions to volatility shocks, i.e., to a change in the underlying return distribution in an investment experiment with sequential price and return realizations.

\footnotetext{
${ }^{15}$ We observe that that finance professionals' investments in the experiment were 12 percent lower in March 2020 than in December 2019, although their price expectations had not changed, and although they considered the experimental asset less risky during the crash than before. See Huber et al. (2021) for the full study including all hypotheses, detailed analyses, and discussions thereof.
} 
Our key findings from this experiment are that (1) investment propensity among finance professionals is negatively associated with the direction of the shock (consistent with Prospect Theory and with a belief in mean reversion of prices) and that (2) students tend to invest less in a risky stock in general. Moreover, (3) finance professionals' trading recommendations for others are largely in line with their own investment behavior, albeit they tend to be more cautious with the recommendations, pointing to prudence as investment advisors. Next, we showed that (4) finance professionals' and students' investment satisfaction is positively correlated with the direction of the shock in both presentation formats. Here, we find that satisfaction shifts are short-term, as they reach pre-shock levels already one period after the shock. Next, we found that (5) finance professionals perceived shocks of different directions to increase risk in similar ways. (6) Students differed in one important aspect from the decisions of professionals: they did not perceive upwardly-trending shocks to increase the riskiness of the stock, but considered higher levels of risk primarily with downwardly-trending or straight shocks. Finally, we reported that (7) finance professionals' price or return forecasts were in the direction of the shock. Whereas professionals did not show differences in forecasts between presentation formats, students showed more extreme price forecasts in the returns condition following straight and upward shocks.

Considering real-world implications, it is comforting to see that finance professionals-in contrast to students-saw that a volatility cluster points to increased risk, even in cases in which the main direction of price changes is positive, i.e., when prices rise. It is crucial for financial advisors to understand and interpret risks and shifts in volatility correctly, in order to adapt clients' portfolios and to give appropriate expert advice. While we did report some differences between finance professionals and students, most patterns are very similar between these two participant pools. 


\section{References}

Alizadeh, S., Brandt, M. W., \& Diebold, F. X. (2002). Range-based estimation of stochastic volatility models. Journal of Finance, 57(3), 1047-1091.

Andersen, T. G., \& Bollerslev, T. (1997). Heterogeneous Information Arrivals and Return Volatility Dynamics: Uncovering the Long-Run in High Frequency Returns. The Journal of Finance, 52(3), 975-1005.

Benartzi, S. D., \& Thaler, R. (1995). Myopic loss aversion and the equity premium puzzle. The Quarterly Journal of Economics, 110(1), 73-92.

Benjamin, D. J., Berger, J. O., Johannesson, M., Nosek, B. A., Wagenmakers, E.-J., Berk, R., Bollen, K. A., Brembs, B., Brown, L., Camerer, C. F., Cesarini, D., Chambers, C. D., Clyde, M., Cook, T. D., De Boeck, P., Dienes, Z., Dreber, A., Easwaran, K., Efferson, C., Fehr, E., Fidler, F., Field, A. P., Forster, M., George, E. I., Gonzalez, R., Goodman, S., Green, E., Green, D. P., Greenwald, A. G., Hadfield, J. D., Hedges, L. V., Held, L., Hua Ho, T., Hoijtink, H., Hruschka, D. J., Imai, K., Imbens, G., Ioannidis, J. P. A., Jeon, M., Jones, J. H., Kirchler, M., Laibson, D., List, J., Little, R., Lupia, A., Machery, E., Maxwell, S. E., McCarthy, M., Moore, D. A., Morgan, S. L., Munafó, M., Nakagawa, S., Nyhan, B., Parker, T. H., Pericchi, L., Perugini, M., Rouder, J., Rousseau, J., Savalei, V., Schönbrodt, F. D., Sellke, T., Sinclair, B., Tingley, D., Van Zandt, T., Vazire, S., Watts, D. J., Winship, C., Wolpert, R. L., Xie, Y., Young, C., Zinman, J., \& Johnson, V. E. (2018). Redefine statistical significance. Nature Human Behaviour, 2(1), 6-10.

Black, F., \& Scholes, M. (1973). The Pricing of Options and Corporate Liabilities. Journal of Political Economy, 81(3), 637-654.

Bock, O., Baetge, I., \& Nicklisch, A. (2014). hroot: Hamburg Registration and Organization Online Tool. European Economic Review, 71, 117-120.

Borsboom, C., \& Zeisberger, S. (2020). What makes an investment risky? An analysis of price path characteristics. Journal of Economic Behavior \& Organization, 169, 92-125.

Bradbury, M. A., Hens, T., \& Zeisberger, S. (2015). Improving investment decisions with simulated experience. Review of Finance, 19(3), 1019-1052.

Cogley, T., \& Sargent, T. J. (2008). The market price of risk and the equity premium: A legacy of the Great Depression? Journal of Monetary Economics, 55(3), 454-476.

Cohn, A., Engelmann, J., Fehr, E., \& Maréchal, M. A. (2015). Evidence for Countercyclical Risk Aversion: An Experiment with Financial Professionals. American Economic Review, 105(2), 860-885.

Corgnet, B., Cornand, C., \& Hanaki, N. (2020). Tail events, emotions and risk taking. Working Paper.

Corgnet, B., Deck, C., Desantis, M., \& Porter, D. (2021). Forecasting skills in experimental markets: Illusion or reality? Management Science. Forthcoming.

Diacon, S., \& Hasseldine, J. (2007). Framing effects and risk perception: The effect of prior performance presentation format on investment fund choice. Journal of Economic Psychology, 28(1), 31-52.

Dohmen, T., Falk, A., Huffman, D., Sunde, U., Schupp, J., \& Wagner, G. G. (2011). Individual risk attitudes: Measurement, determinants, and behavioral consequences. Journal of the European Economic Association, $9(3), 522-550$.

Dow, J., \& da Costa Werlang, S. R. (1992). Excess volatility of stock prices and Knightian uncertainty. European Economic Review, 36(2), 631-638.

Ehm, C., Kaufmann, C., \& Weber, M. (2014). Volatility inadaptability: Investors care about risk, but cannot cope with volatility. Review of Finance, 18(4), 1387-1423. 
Epstein, L., \& Wang, T. (1994). Intertemporal asset pricing under knightian uncertainty. Econometrica, 62(2), 283-322.

Glaser, M., Iliewa, Z., \& Weber, M. (2019). Thinking about Prices versus Thinking about Returns in Financial Markets. The Journal of Finance, 74(6), 2997-3039.

Glaser, M., Langer, T., Reynders, J., \& Weber, M. (2007). Framing effects in stock market forecasts: The difference between asking for prices and asking for returns. Review of Finance, 11(2), 325-357.

Graham, J. R., \& Narasimhan, K. (2005). Corporate Survival and Managerial Experiences During the Great Depression. Working Paper.

Grosshans, D., \& Zeisberger, S. (2018). All's well that ends well? On the importance of how returns are achieved. Journal of Banking \& Finance, 87, 397-410.

Guiso, L., Sapienza, P., \& Zingales, L. (2018). Time varying risk aversion. Journal of Financial Economics, 128(3), 403-421.

Haigh, M. S., \& List, J. A. (2005). Do Professional Traders Exhibit Myopic Loss Aversion? An Experimental Analysis. The Journal of Finance, 60(1), 523-534.

Hertwig, R., Barron, G., Weber, E. U., \& Erev, I. (2004). Decisions from experience and the effect of rare events in risky choice. Psychological Science, 15(8), 534-539.

Hertwig, R., \& Erev, I. (2009). The description-experience gap in risky choice. Trends in Cognitive Sciences, 13(12), 517-523.

Heston, S. L. (1993). A closed-form solution for options with stochastic volatility with applications to bond and currency options. The Review of Financial Studies, 6(2), 327-343.

Holzmeister, F., Huber, C., \& Palan, S. (2021). A critical perspective on the conceptualization of risk in behavioral and experimental finance. In S. Füllbrunn, \& E. Haruvy (Eds.) Handbook of Experimental Finance. Edward Elgar Publishing.

Holzmeister, F., Huber, J., Kirchler, M., Lindner, F., Weitzel, U., \& Zeisberger, S. (2020). What drives risk perception? A global survey with financial professionals and laypeople. Management Science, 66(9), 3977-4002.

Huber, C., \& Huber, J. (2019). Scale matters: risk perception, return expectations, and investment propensity under different scalings. Experimental Economics, 22(1), 76-100.

Huber, C., Huber, J., \& Hueber, L. (2019). The effect of experts' and laypeople's forecasts on others' stock market forecasts. Journal of Banking and Finance, 109, 105662.

Huber, C., Huber, J., \& Kirchler, M. (2021). Market shocks and professionals' investment behavior - Evidence from the COVID-19 crash. Journal of Banking \& Finance, 133, 106247.

Jiao, P. (2017). Belief in mean reversion and the disposition effect: An experimental test. Journal of Behavioral Finance, 18(1), 29-44.

Kaufmann, C., Weber, M., \& Haisley, E. (2013). The Role of Experience Sampling and Graphical Displays on One's Investment Risk Appetite. Management Science, 59(2), 323-340.

Kaustia, M., \& Knüpfer, S. (2008). Do Investors Overweight Personal Experience? Evidence from IPO Subscriptions. The Journal of Finance, 63(6), 2679-2702.

Kirchler, M., Lindner, F., \& Weitzel, U. (2018). Rankings and Risk-Taking in the Finance Industry. The Journal of Finance, 73(5), 2271-2302. 
Kostopoulos, D., Meyer, S., \& Uhr, C. (2021). Ambiguity about volatility and investor behavior. Journal of Financial Economics. Forthcoming.

Malmendier, U., \& Nagel, S. (2011). Depression Babies: Do Macroeconomic Experiences Affect Risk Taking? The Quarterly Journal of Economics, 126(1), 373-416.

Mandelbrot, B. B., \& Hudson, R. L. (2008). The (Mis)Behaviour of Markets: A Fractal View of Risk, Ruin and Reward. Profile Books.

Merton, R. C. (1969). Lifetime Portfolio Selection under Uncertainty: The Continuous-Time Case. The Review of Economics and Statistics, 51(3), 247.

Nosek, B. A., \& Errington, T. M. (2020). What is replication? PLOS Biology, 18(3), e3000691.

Nosić, A., \& Weber, M. (2010). How riskily do i invest? The role of risk attitudes, risk perceptions, and overconfidence. Decision Analysis, 7(3), 282-301.

Odean, T. (1998). Are Investors Reluctant to Realize Their Losses? The Journal of Finance, 53(5), 17751798.

Payzan-LeNestour, E., Balleine, B. W., Berrada, T., \& Pearson, J. (2016). Variance After-Effects Distort Risk Perception in Humans. Current Biology, 26(11), 1500-1504.

Payzan-LeNestour, E., Pradier, L., \& Putninšs, T. J. (2021). The "Waterfall Illusion" in the Perception of Risk. Working Paper.

Polman, E., \& Wu, K. (2020). Decision making for others involving risk: A review and meta-analysis. Journal of Economic Psychology, 77, 102184.

Samuelson, P. A. (1969). Lifetime portfolio selection by dynamic stochastic programming. The Review of Economics and Statistics, (pp. 239-246).

Schmidt, S. (2009). Shall we Really do it Again? The Powerful Concept of Replication is Neglected in the Social Sciences. Review of General Psychology, 13(2), 90-100.

Schwaiger, R., Kirchler, M., Lindner, F., \& Weitzel, U. (2019). Determinants of investor expectations and satisfaction. A study with financial professionals. Journal of Economic Dynamics and Control, 110, 103675.

Shefrin, H., \& Statman, M. (1985). The disposition to sell winners too early and ride losers too long: Theory and evidence. Journal of Finance, 40(4), 777-790.

Taleb, N. N. (2007). The Black Swan. Random House.

Thaler, R. H., Tversky, A., Kahneman, D., \& Schwartz, A. (1997). The effect of myopia and loss aversion on risk taking: An experimental test. The quarterly journal of economics, 112(2), 647-661.

Tobin, J. (1958). Liquidity preference as behavior towards risk. The Review of Economic Studies, 25(2), 65-86.

Toplak, M. E., West, R. F., \& Stanovich, K. E. (2014). Assessing miserly information processing: An expansion of the Cognitive Reflection Test. Thinking and Reasoning, 20(2), 147-168.

Weber, E. U., Siebenmorgen, N., \& Weber, M. (2005). Communicating asset risk: How name recognition and the format of historic volatility information affect risk perception and investment decisions. Risk Analysis, 25(3), 597-609.

Weitzel, U., Huber, C., Huber, J., Kirchler, M., Lindner, F., \& Rose, J. (2020). Bubbles and financial professionals. The Review of Financial Studies, 33(6), 2659-2696. 
Zeisberger, S. (2020). What is Risk? How Investors Perceive Risk in Return Distributions. Working Paper.

Zhang, X., Liu, Y., Chen, X., Shang, X., \& Liu, Y. (2017). Decisions for Others Are Less Risk-Averse in the Gain Frame and Less Risk-Seeking in the Loss Frame Than Decisions for the Self. Frontiers in Psychology, 8 . 


\title{
Online Appendix to Volatility Shocks and Investment Behavior
}

\author{
Christoph Huber, Jürgen Huber, Michael Kirchler ${ }^{\dagger}$
}

\section{A Instructions of the Experiment}

Dear participant,

Thank you very much for accepting our invitation to take part in this short online experiment. It takes approximately 15 minutes. The experiment has real monetary incentives and the payoff will vary depending on your decisions.

All data will be anonymous and no individual results will be disclosed publicly or to other participants of the experiment.

Please do not use your mobile phone or tablet-visibility is much better on a computer screen.

The experiment is open for the upcoming 4 weeks. If the maximum number of participants has been reached before this deadline, we will close the experiment.

Thank you very much for your contribution to science and good luck in the experiment!

(new page)

\section{The Experiment}

The following experiment consists of three parts. In each of the three parts, you will make investment decisions in a financial market. In each part, you have to decide in each of five months/rounds, which percentage of your wealth you want to invest in the risky stock shown in this part. The wealth not invested is held in cash.

The risky stocks' returns in all parts are based on a distribution of returns from actual historical data of large stock indices from the last 20 years. During this time, the stock indices' development was characterized by fluctuations. The distribution of daily returns for the risky stocks corresponds to earning an average daily return of $0.03 \%$ (that corresponds to an average yearly return of $6.44 \%$ ) with a standard deviation of daily returns of $2.36 \%$.

Here are some examples on the likelihood of various price fluctuations:

- In 50 out of 100 cases, the daily return is between $-0.60 \%$ and $0.73 \%$.

- In 90 out of 100 cases, the daily return is between $-2.77 \%$ and $2.77 \%$.

- In 95 out of 100 cases, the daily return is between $-6.06 \%$ and $6.32 \%$.

(new page)

Procedure

Each of the three parts consists of five months. At the start of each month you can invest between $0 \%$ and

${ }^{\dagger}$ All materials of the experiment (e.g., source codes, data files) are publicly available in the Open Science Framework (OSF) repository osf.io/9chg8. 
$100 \%$ of your wealth in the respective risky stock. If you invest less than $100 \%$ of your wealth in the risky stock, the amount not invested in the risky stock is held in cash.

Each month consists of 20 trading days and therefore contains 20 daily returns. Every 0.5 seconds, one daily return from the distribution described above is realized and displayed on the screen.

$$
\text { (new page) }
$$

Payment

At the end of the experiment, one of the five months from one of the three parts will be randomly selected to determine your payment. Your percentage return from this randomly selected month times three is then added to an endowment of EUR 20.

Example: If you invest $70 \%$ of your wealth in the risky stock in the randomly selected month and the stock's return in this month is $15 \%$, then your return from this month will be $70 \% \times 15 \%=10.5 \%$. Your payment from this experiment is then EUR $20 \times(1+10.5 \% \times 3)=$ EUR 26.30 . 


\section{Part 1 | Month 1 / 5}

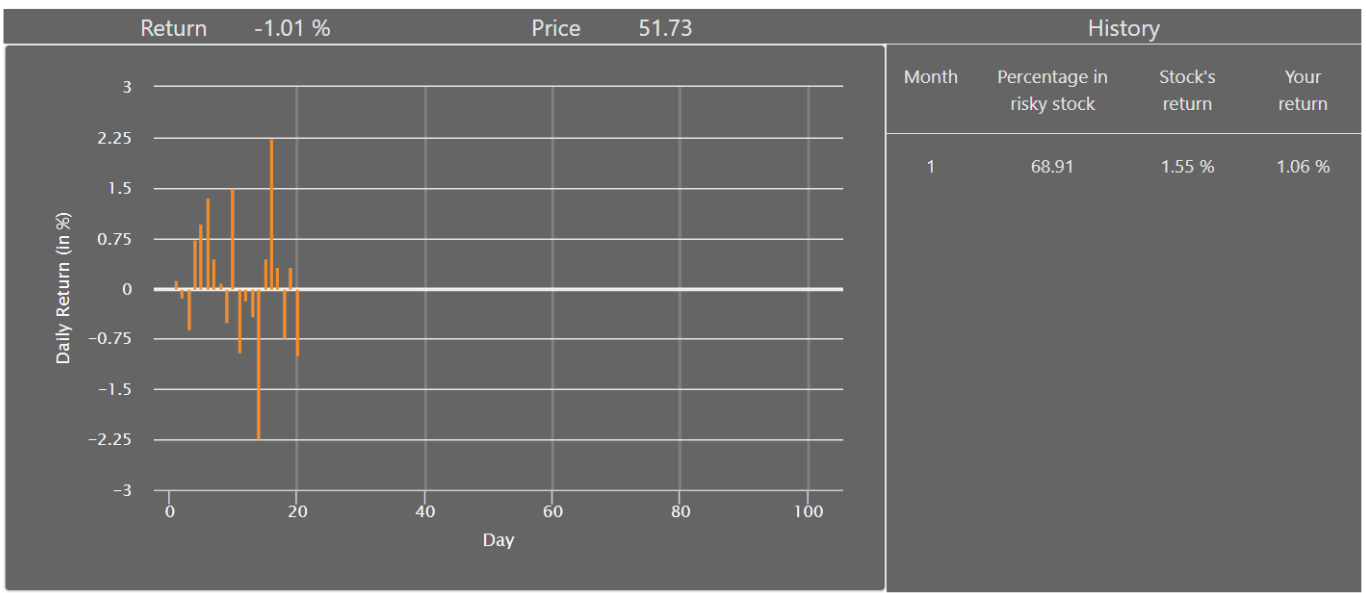

Please enter your decisions.

Please state your satisfaction with the stock on a scale ranging from -3 to 3 , where -3 indicates 'very unsatisfied' and 3 indicates 'very satisfied'.

$\begin{array}{ccccccc}0 & 0 & 0 & 0 & 0 & 0 & 0 \\ -3 & -2 & -1 & 0 & 1 & 2 & 3 \\ \begin{array}{c}\text { very } \\ \text { unsatisfied }\end{array} & & & & & & \\ \text { very } \\ \text { satisfied }\end{array}$

If you were an analyst, would your recommendation for the stock be SELL, HOLD or BUY?

$\begin{array}{ccccc}0 & 0 & \bigcirc & 0 & 0 \\ 1 & 2 & 3 & 4 & 5 \\ \begin{array}{c}\text { strong } \\ \text { sell }\end{array} & & \text { hold } & & \begin{array}{c}\text { strong } \\ \text { buy }\end{array}\end{array}$

How risky do you perceive this stock on the basis of its past returns?

$\begin{array}{ccccccc}0 & 0 & 0 & 0 & 0 & 0 & 0 \\ 1 & 2 & 3 & 4 & 5 & 6 & 7 \\ \begin{array}{c}\text { not risky } \\ \text { at all }\end{array} & & & & & & \text { very } \\ & & & & & & \text { risky }\end{array}$

What is your estimate of the most likely monthly return in the next month?

What is your pessimistic estimate for the monthly return in the next month? (only in $5 \%$ of cases the actual monthly return will be below this return)

What is your optimistic estimate for the monthly return in the next month? (only in $5 \%$ of cases the actual monthly return will be above this return)

\section{Your allocation:}

What percentage of your wealth do you want to hold in the risky stock in the next month?
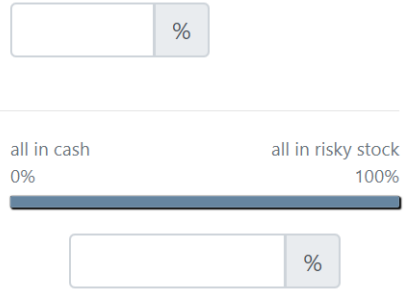

Figure A1: Screenshot of the decision screen with a RETURN chart. 


\section{Part 1 | Month 1 / 5}

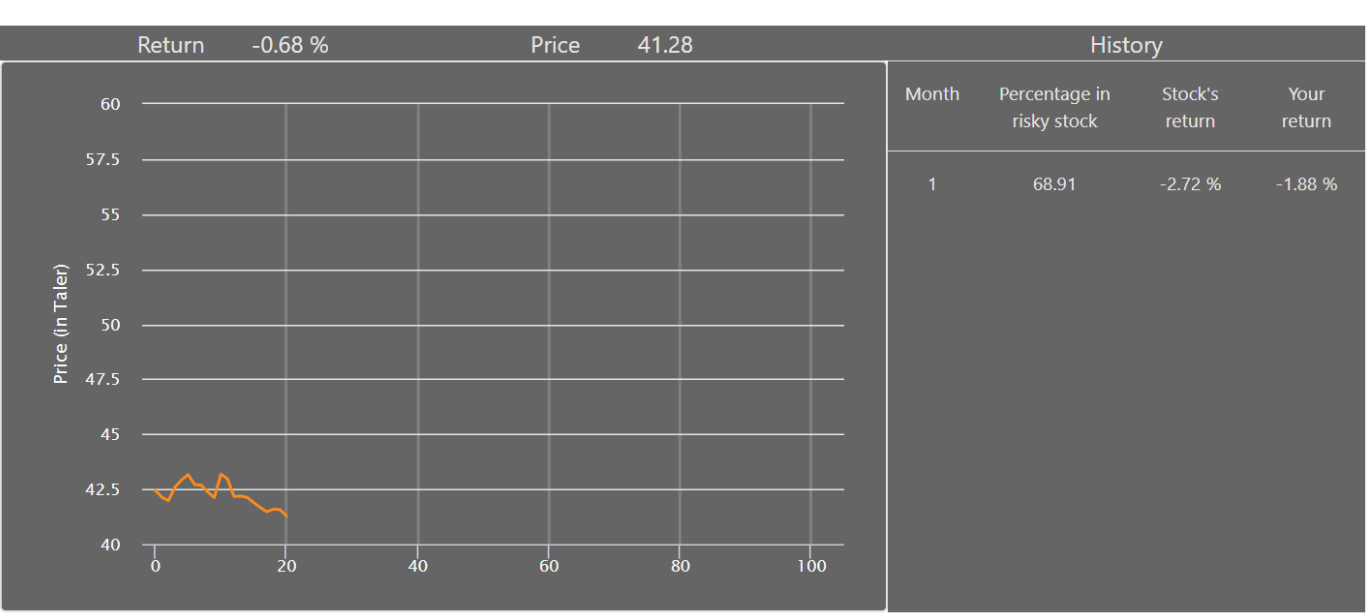

Please enter your decisions.

Please state your satisfaction with the stock on a scale ranging from -3 to 3 , where -3 indicates 'very unsatisfied' and 3 indicates 'very satisfied'.

$\begin{array}{ccccccc}0 & 0 & 0 & 0 & 0 & 0 & 0 \\ -3 & -2 & -1 & 0 & 1 & 2 & 3 \\ \begin{array}{c}\text { very } \\ \text { unsatisfied }\end{array} & & & & & & \\ \text { very } \\ \text { satisfied }\end{array}$

If you were an analyst, would your recommendation for the stock be SELL, HOLD or BUY?

$\begin{array}{ccccc}\bigcirc & \bigcirc & \bigcirc & \bigcirc & \bigcirc \\ 1 & 2 & 3 & 4 & 5 \\ \begin{array}{c}\text { strong } \\ \text { sell }\end{array} & \text { sell } & \text { hold } & \text { buy } & \begin{array}{c}\text { strong } \\ \text { buy }\end{array}\end{array}$

How risky do you perceive this stock on the basis of its past returns?

$$
\begin{array}{ccccccc}
0 & 0 & 0 & 0 & 0 & 0 & 0 \\
1 & 2 & 3 & 4 & 5 & 6 & 7 \\
\begin{array}{c}
\text { not risky } \\
\text { at all }
\end{array} & & & & & & \text { very } \\
& & & & & & \text { risky }
\end{array}
$$

What is your estimate of the most likely stock price at the end of the next month?

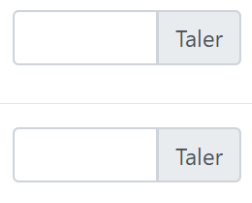

What is your pessimistic estimate for the stock price at the end of the next month?

(only in $5 \%$ of cases the stock price will be below this price)

What is your optimistic estimate for the stock price at the end of the next month?

(only in $5 \%$ of cases the stock price will be above this price)

Your allocation:

What percentage of your wealth do you want to hold in the risky stock in the next month?
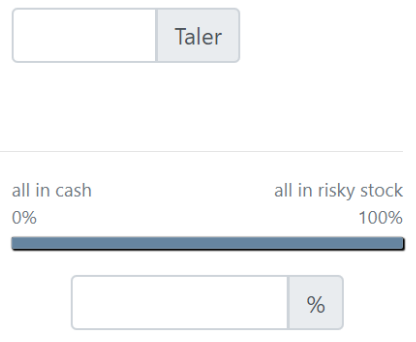

Figure A2: Screenshot of the decision screen with a PRICE chart. 


\section{B Additional Figures}
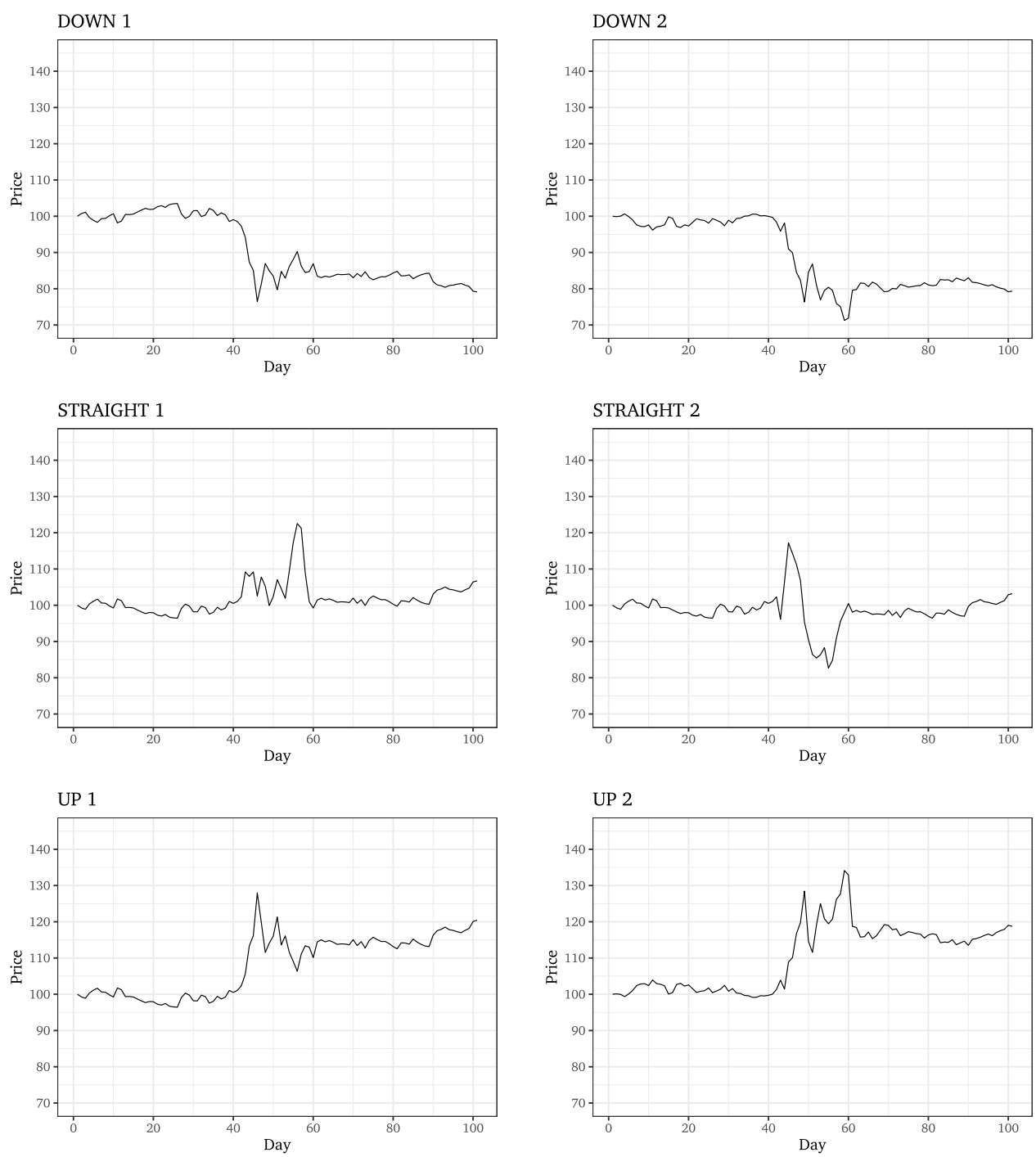

Figure B1: Price Charts. Overview over the six price paths run in the experiment. The shocks are modeled in period three. Each participant is presented with each of the path-types DOWN, STRAIGHT, and UP in random order in such a way that a participant either sees DOWN 1 and UP 2 or vice versa. 



Figure B2: Return Charts. Overview over the six return paths run in the experiment. The shocks are modeled in period three. Each participant is presented with each of the path-types Down, STRAIGHT, and UP in random order in such a way that a participant either sees DOWN 1 and UP 2 or vice versa. 

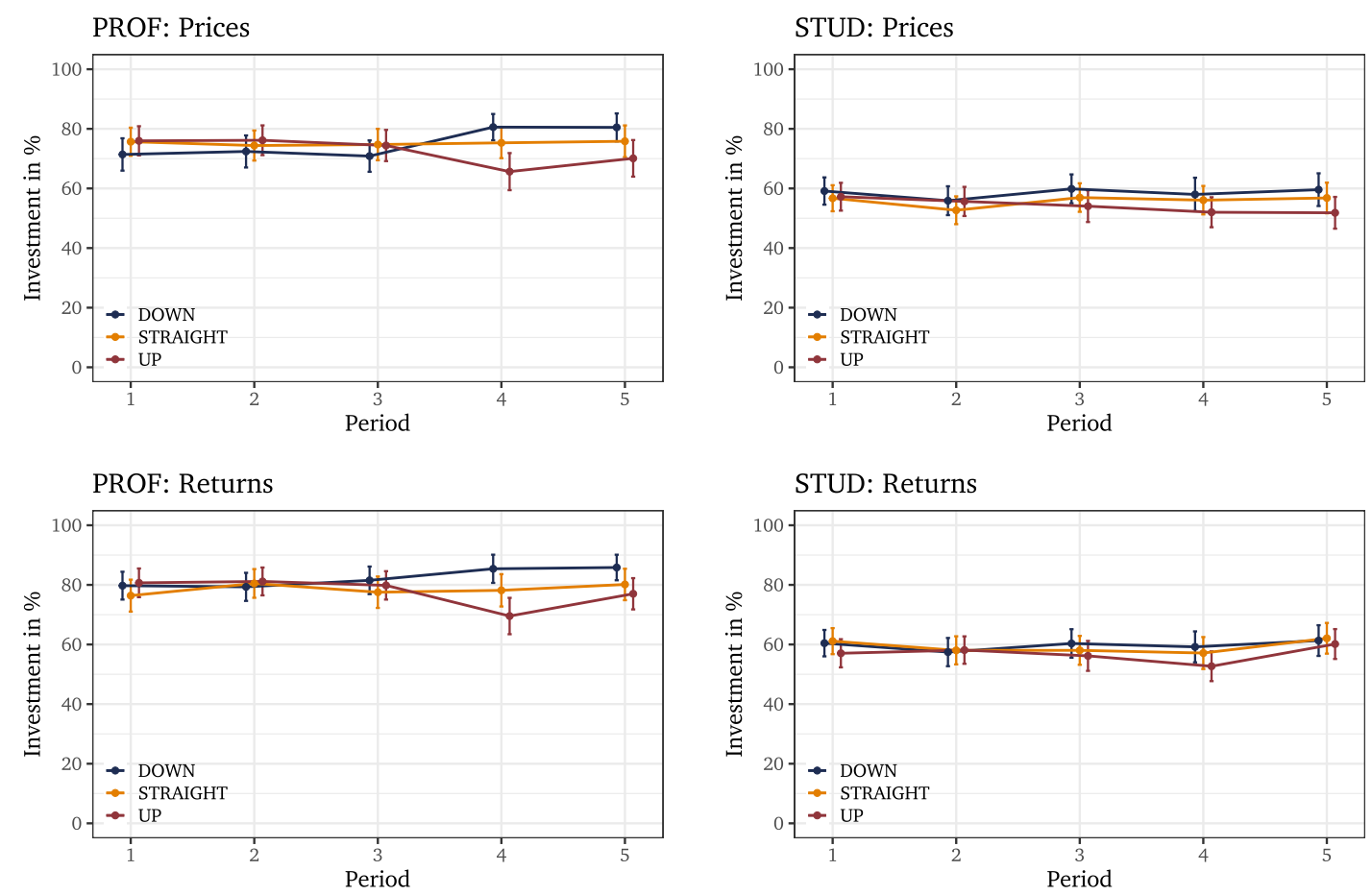

Figure B3: INVESTMENT: percentage invested over time for DOWN, STRAIGHT, UP volatility shocks. The whiskers indicate the 95\% confidence intervals. Results for the professionals (PROF) are shown in the left column, those of the students (STUD) in the right column.
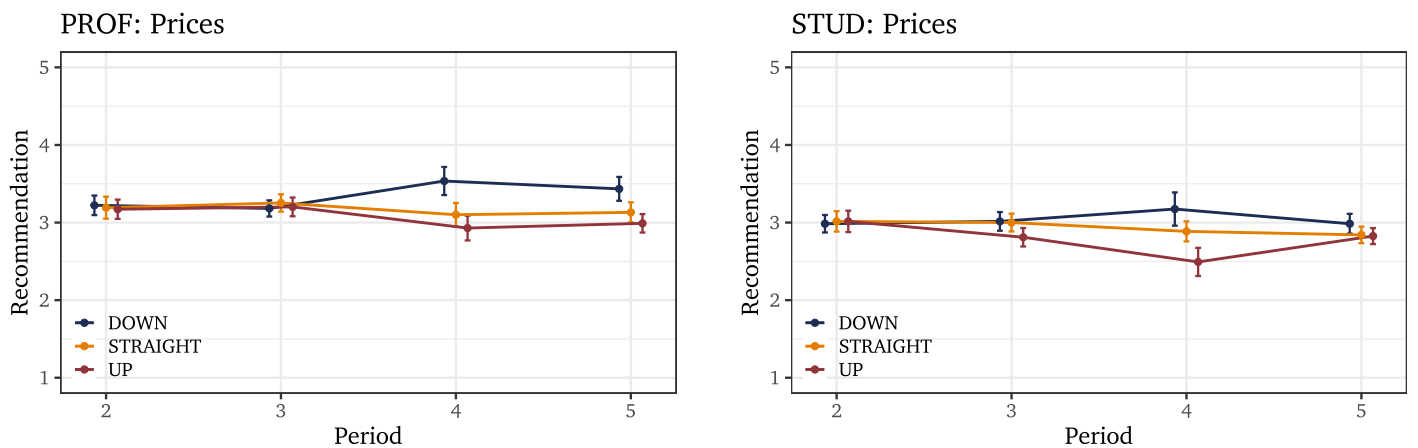

PROF: Returns

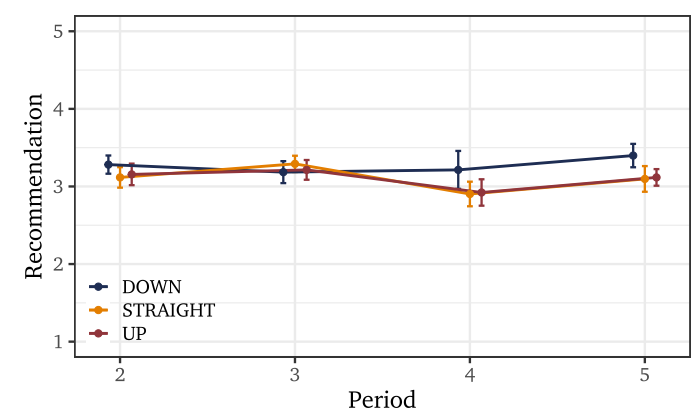

STUD: Returns

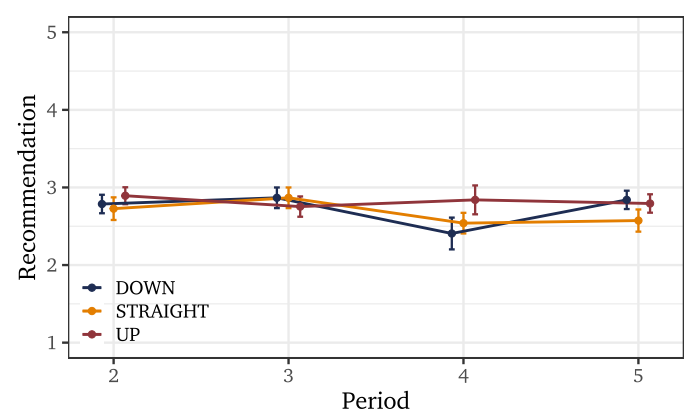

Figure B4: RECOMMENDATION (1: strong sell; 5: strong buy) over time for DOWN, STRAIGHT, UP volatility shocks. The whiskers indicate the 95\% confidence intervals. Results for the professionals (PROF) are shown in the left column, those of the students (STUD) in the right column. 

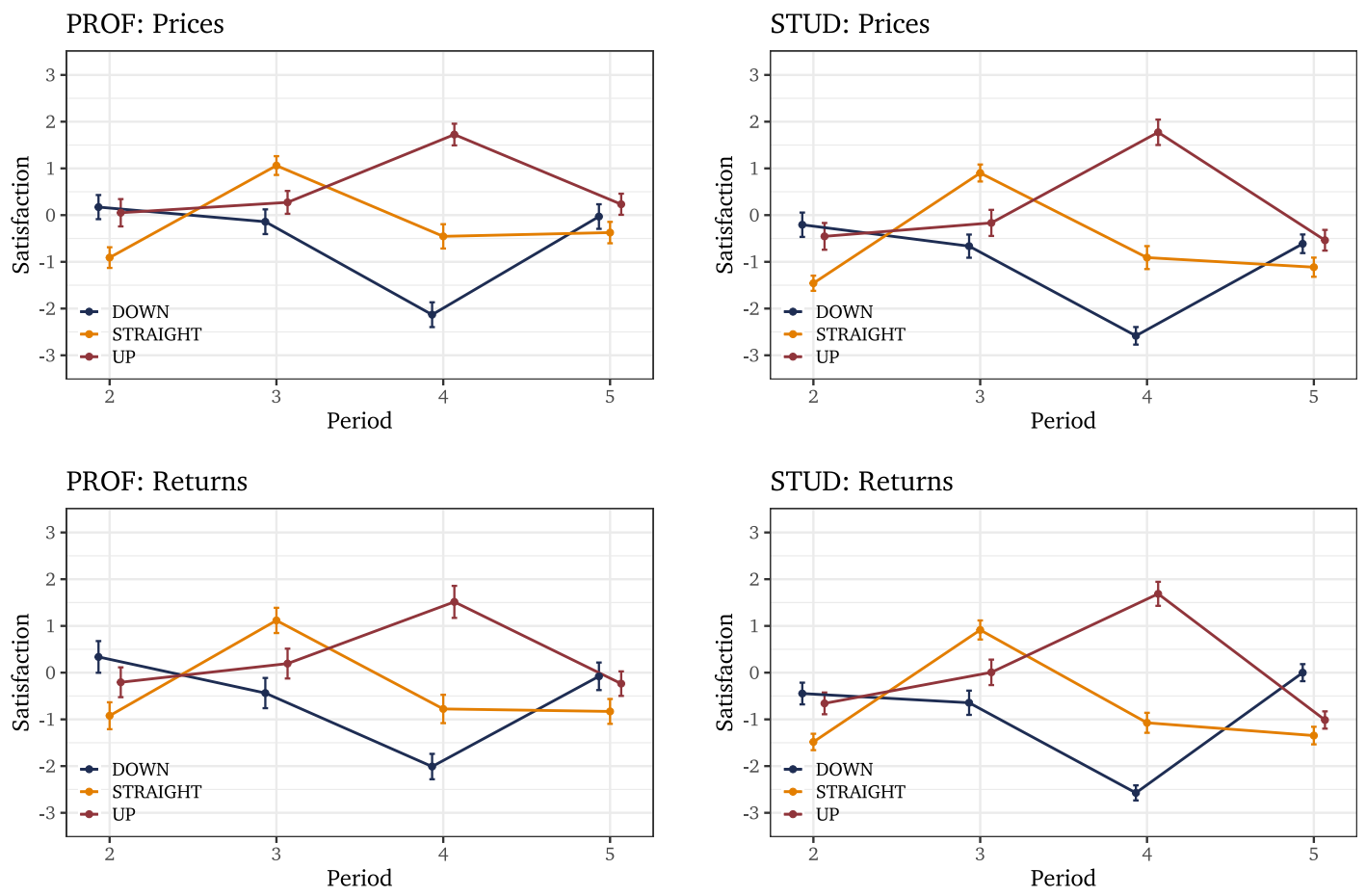

Figure B5: SATISFACTION over time for DOWN, STRAIGHT, UP volatility shocks. The whiskers indicate the 95\% confidence intervals. Results for the professionals (PROF) are shown in the left column, those of the students (STUD) in the right column.
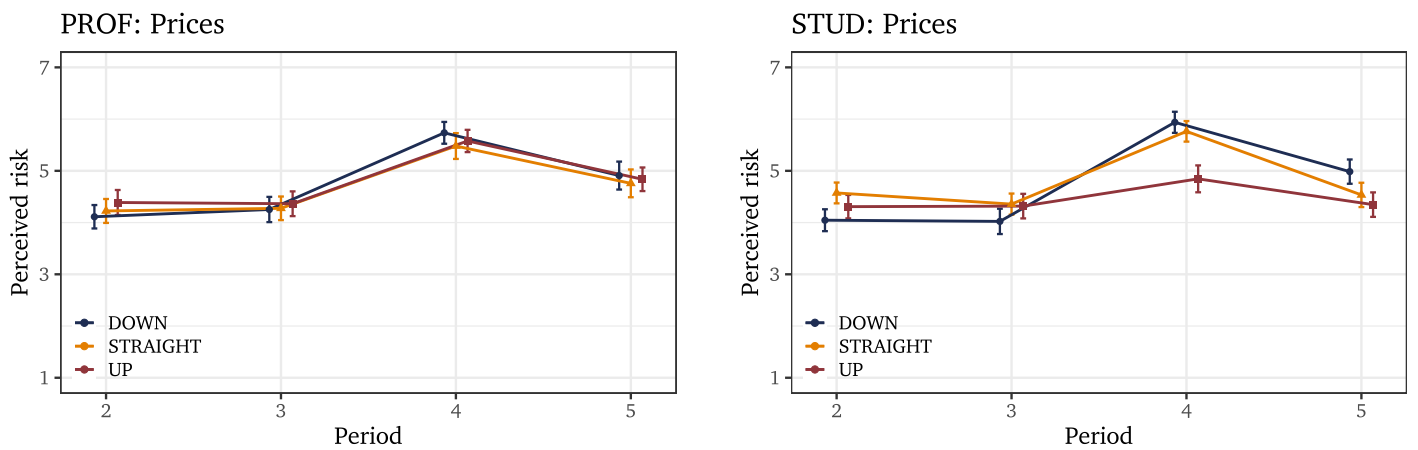

PROF: Returns

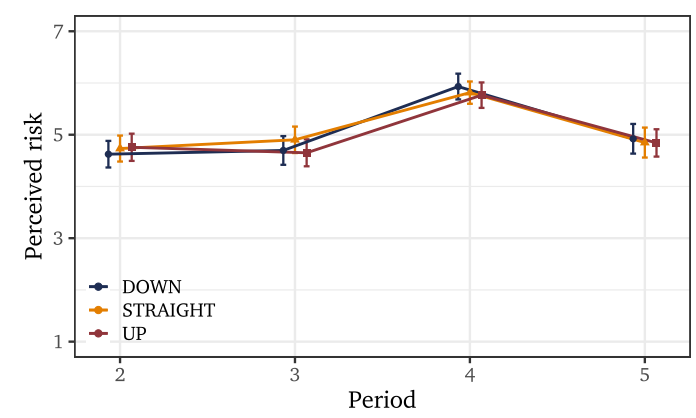

STUD: Returns

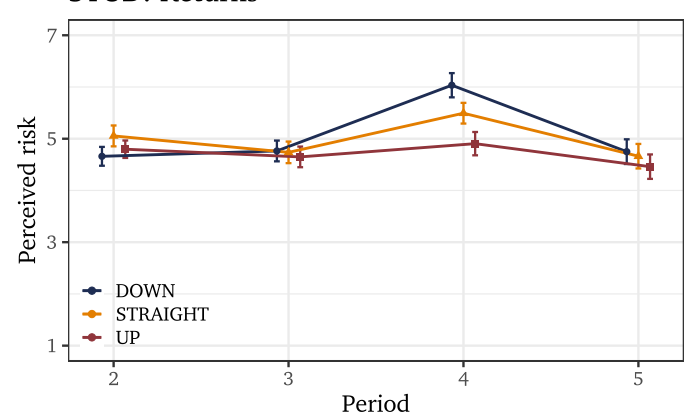

Figure B6: RISK PERCEPTION: perceived risk over time for DOWN, STRAIGHT, UP volatility shocks. The whiskers indicate the 95\% confidence intervals. Results for the professionals (PROF) are shown in the left column, those of the students (STUD) in the right column. 

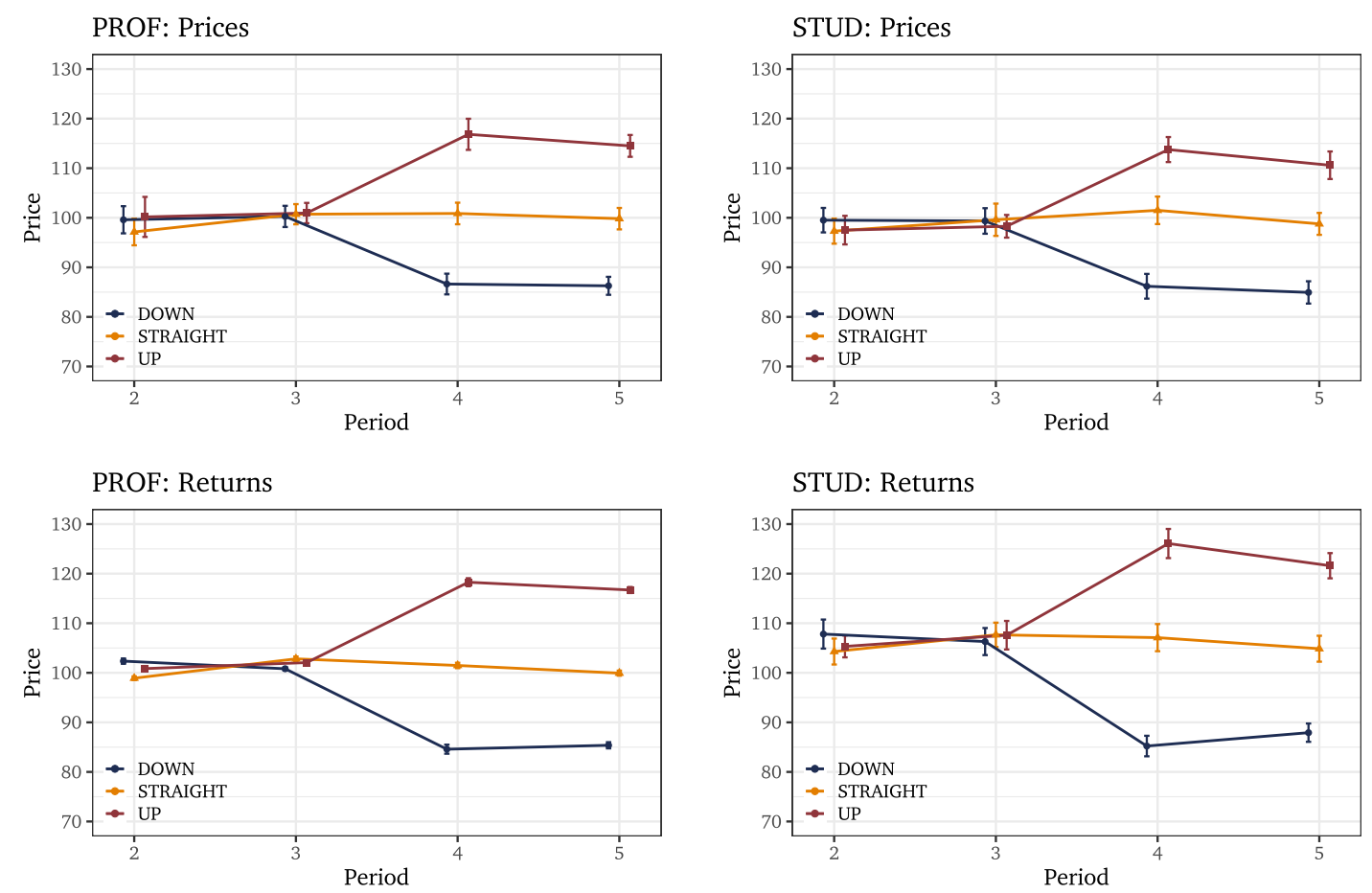

Figure B7: PRICE FORECAST over time for DOWN, STRAIGHT, UP volatility shocks. The whiskers indicate the 95\% confidence intervals. Results for the professionals (PROF) are shown in the left column, those of the students (STUD) in the right column.
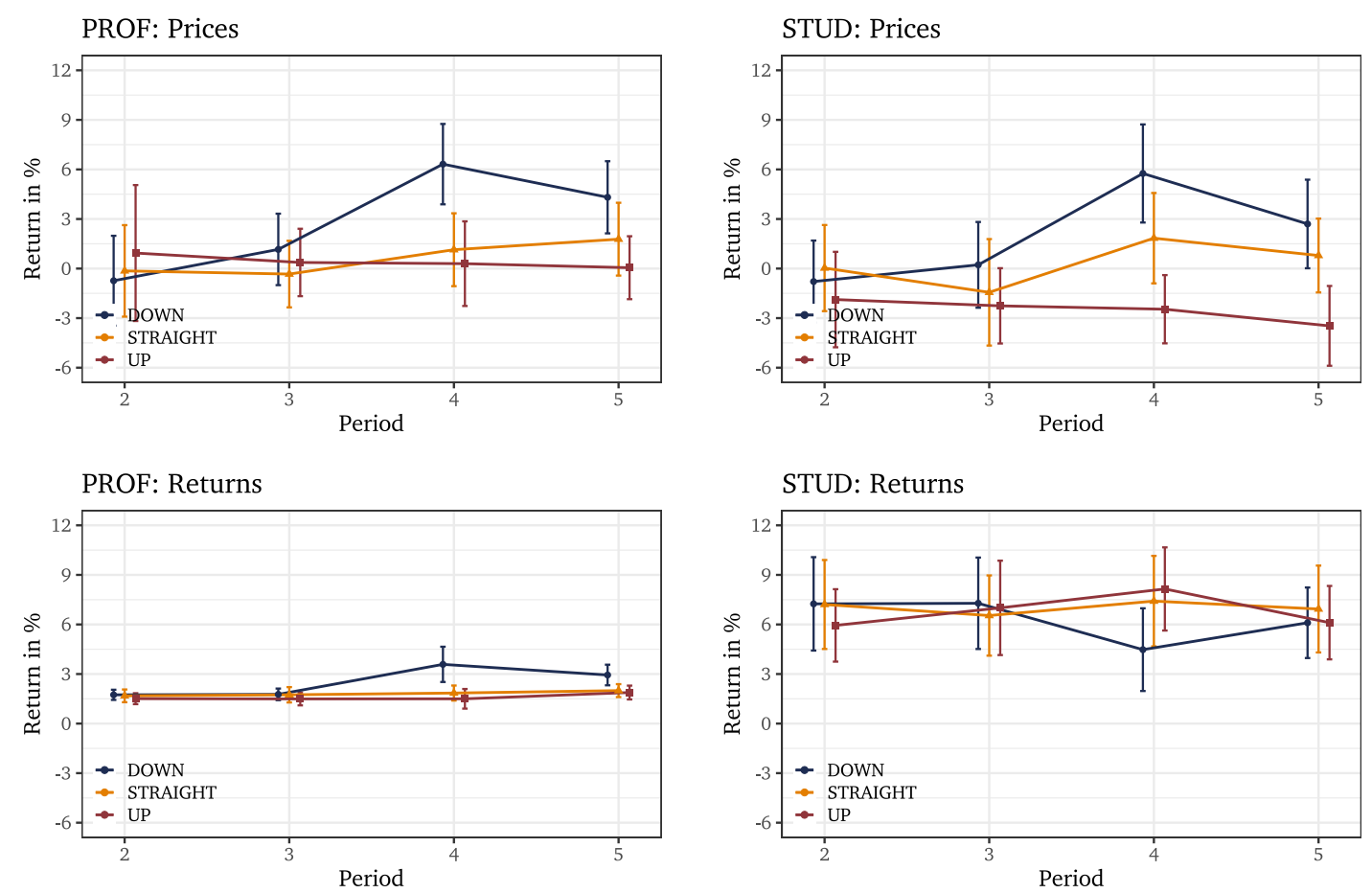

Figure B8: PRICE FORECAST over time for DOWN, STRAIGHT, UP volatility shocks. The whiskers indicate the 95\% confidence intervals. Results for the professionals (PROF) are shown in the left column, those of the students (STUD) in the right column. 
PROF: Prices

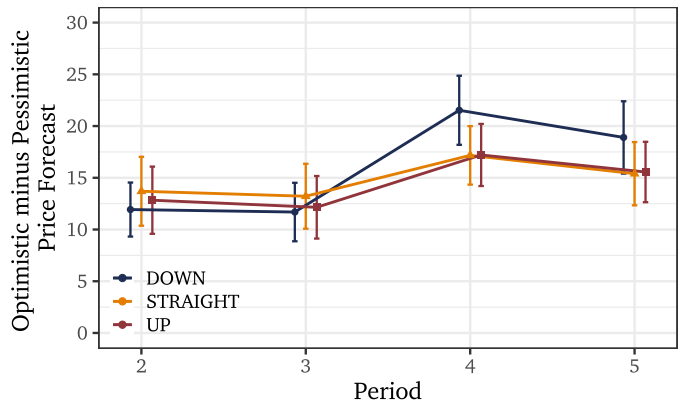

PROF: Returns

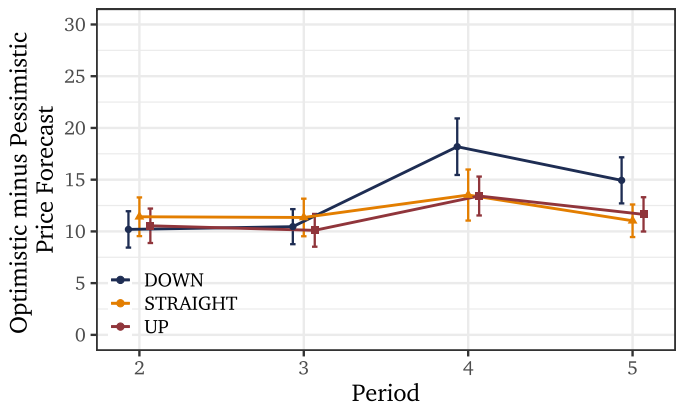

STUD: Prices

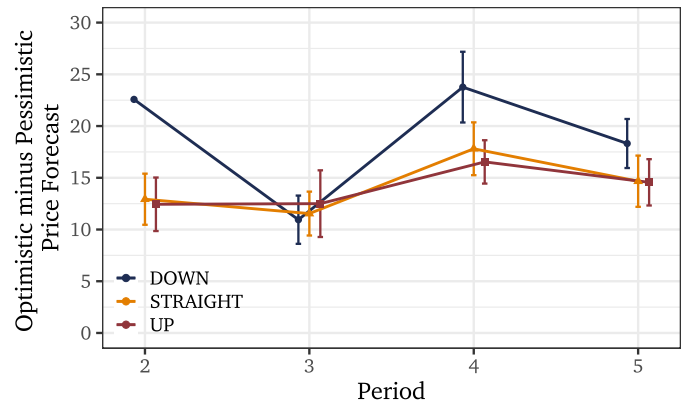

STUD: Returns

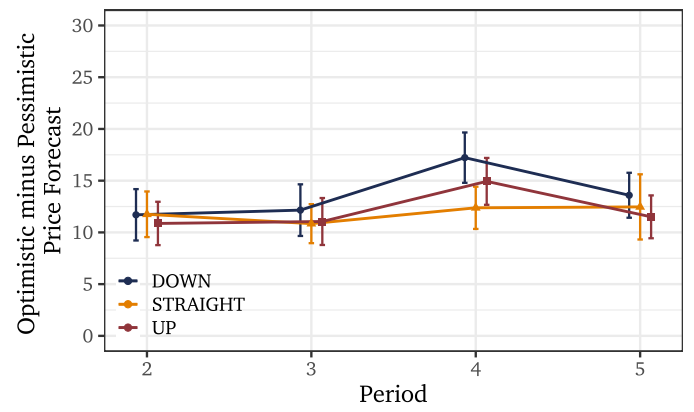

Figure B9: Optimistic minus Pessimistic Forecast: Average difference between the $95^{\text {th }}$ quantile and the $5^{\text {th }}$ quantile (divided by the stock price (return) forecast) over time for DOWN, STRAIGHT, UP volatility shocks. Price forecasts measure the expected price level in Taler (experimental currency unit). Results for the professionals (PROF) are shown in the left column, those of the students (STUD) in the right column. 
PROF: Investment

Fitted values before $(t=2)$ and after $(t>2)$ the shock

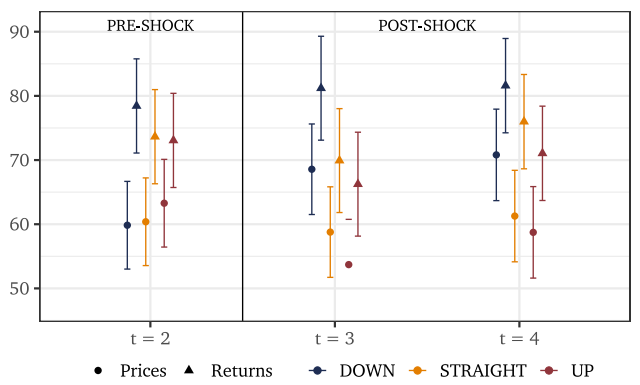

PROF: Recommendation

Fitted values before $(t=2)$ and after $(t>2)$ the shock

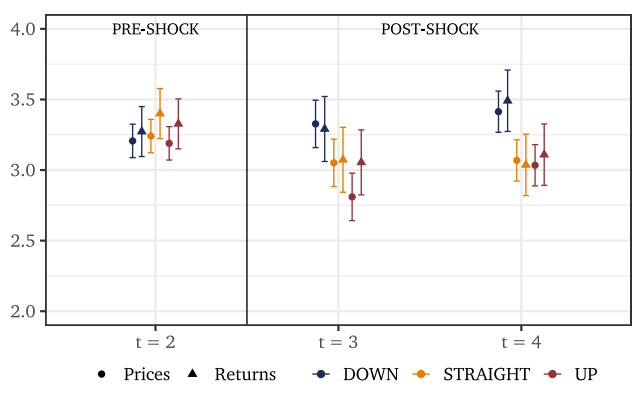

PROF: Satisfaction

Fitted values before $(t=2)$ and after $(t>2)$ the shock

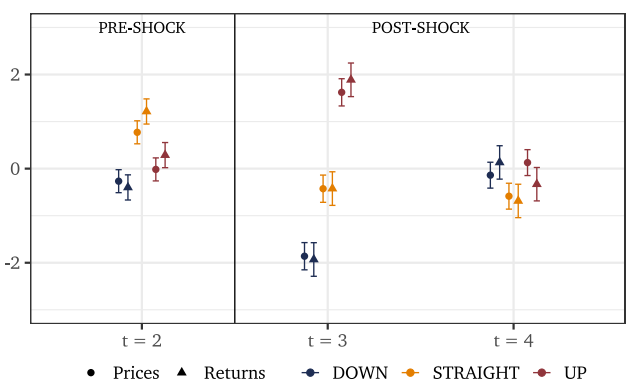

STUD: Investment

Fitted values before $(t=2)$ and after $(t>2)$ the shock

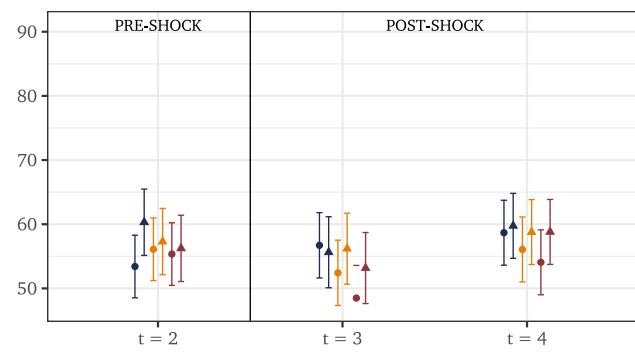

- Prices $\triangle$ Returns $\rightarrow$ DOWN $\rightarrow$ STRAIGHT $\rightarrow$ UP

STUD: Recommendation

Fitted values before $(t=2)$ and after $(t>2)$ the shock

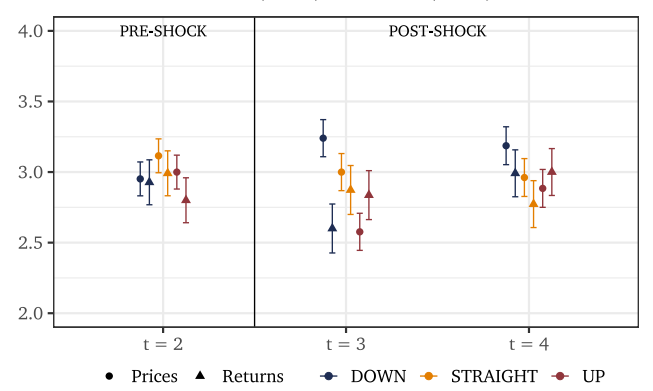

STUD: Satisfaction

Fitted values before $(t=2)$ and after $(t>2)$ the shock

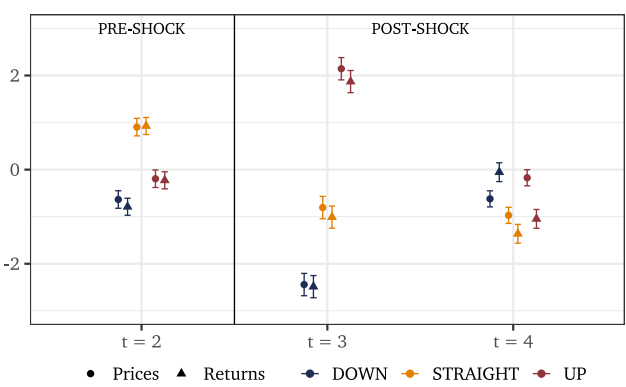

Figure B10: WAVE 2. Fitted values of investment, recommendation, and satisfaction before $(t=2)$, at $(t=3)$, and one period after the shock $(t=4)$ for both presentation formats RETURNS (triangles) and PRICES (dots) and the shock types UP (blue), DOWN (red), and STRAIGHT (green). Fitted values are calculated, including all covariates. Return forecasts are converted into price forecasts for better comparability. The whiskers indicate the $95 \%$ confidence intervals. 
PROF: Risk perception

Fitted values before $(t=2)$ and after $(t>2)$ the shock

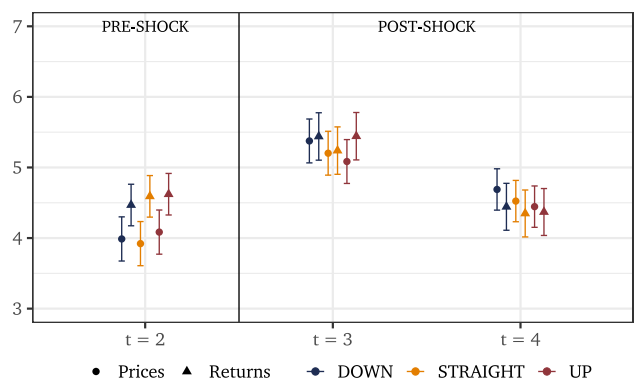

PROF: Price Forecast

Fitted values before $(t=2)$ and after $(t>2)$ the shock

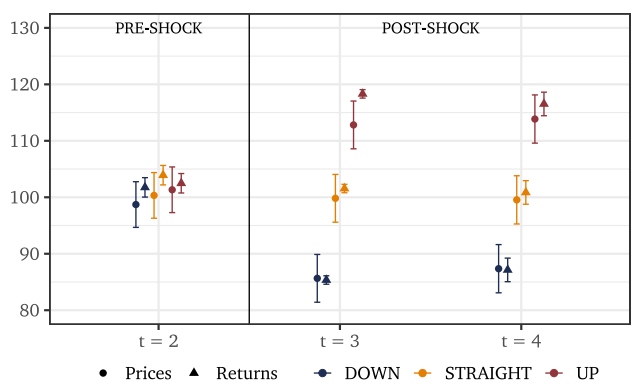

PROF: Return Forecast

Fitted values before $(t=2)$ and after $(t>2)$ the shock

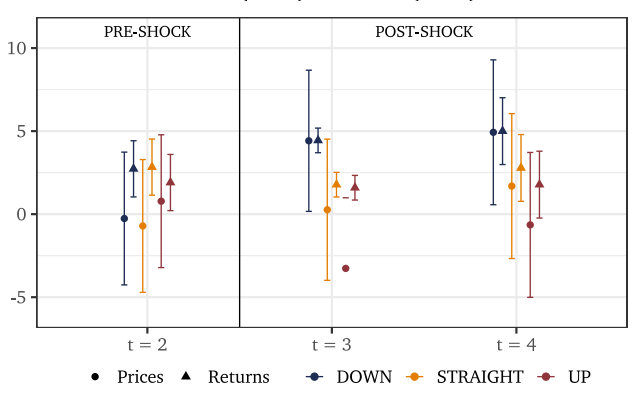

STUD: Risk perception

Fitted values before $(t=2)$ and after $(t>2)$ the shock

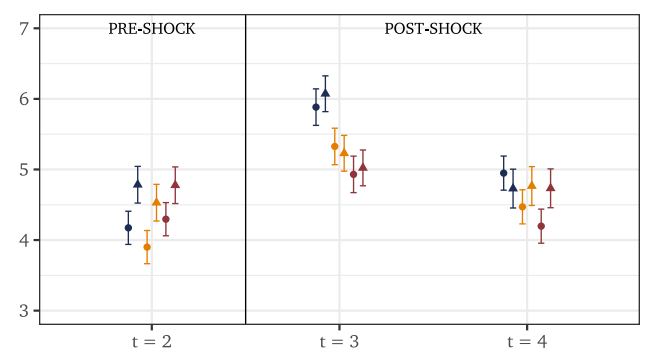

- Prices $\triangle$ Returns $\bullet$ DOWN $\bullet$ STRAIGHT $\bullet$ UP

STUD: Price Forecast

Fitted values before $(t=2)$ and after $(t>2)$ the shock

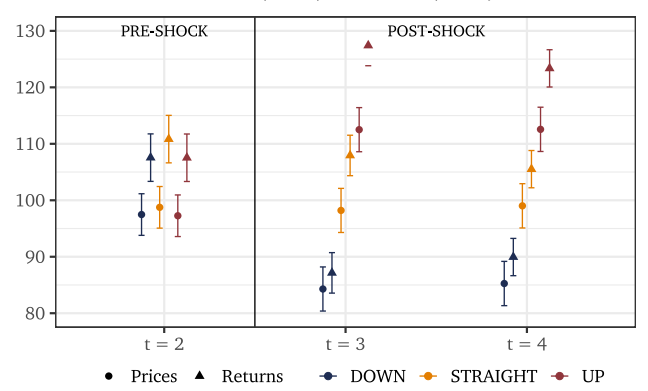

STUD: Return Forecast

Fitted values before $(t=2)$ and after $(t>2)$ the shock

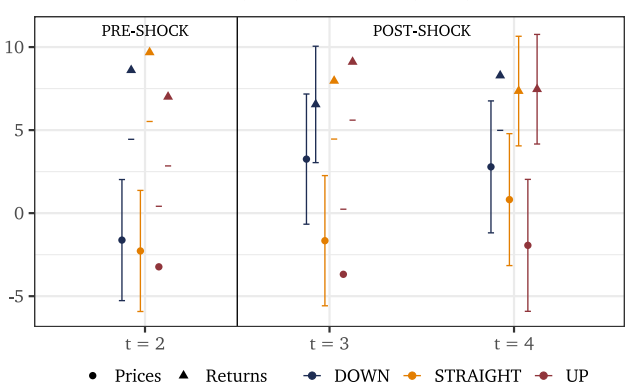

Figure B11: WAVE 2. Fitted values of risk perception and price and return forecasts before $(t=2)$, at $(t=3)$, and one period after the shock $(t=4)$ for both presentation formats RETURNS (triangles) and PRICES (dots) and the shock types UP (blue), DOWN (red), and STRAIGHT (green). Fitted values are calculated, including all covariates. Return forecasts are converted into price forecasts for better comparability. The whiskers indicate the $95 \%$ confidence intervals. 


\section{Additional Tables}

Table C1: Demographic statistics of financial professionals (left column) and student participants (right column). "Risk tolerance (general)" measures participants' risk taking by using the general risk question from the German Socio-Economic Panel on a Likert-scale from 0 ("not willing to take risk") to 10 ("very willing to take risk")—(GSOEP; see Dohmen et al., 2011); "Risk tolerance (financial)" measures participants' risk taking in financial matters taken from GSOEP as well; "CRT2" measures how many out of two cognitive reflection test (CRT) questions from Toplak et al. (2014) were answered correctly (Question 1: "If John can drink one barrel of water in 6 days, and Mary can drink one barrel of water in 12 days, how long would it take them to drink one barrel of water together?" Question 2: "Jerry received both the 15th highest and the 15th lowest mark in the class. How many students are in the class?"); "Investment in financial products" indicates the fraction of participants that have invested in financial products during the past five years. Values in column " $t$ " indicate the respective test statistics from $t$-tests between WAVE 1 (December 2019) and WAVE 2 (March 2020); none of the differences between WAVE 1 and WAVE 2 are statistically significant at the 5\% level.

\begin{tabular}{|c|c|c|c|c|c|c|c|c|c|c|}
\hline \multirow[b]{3}{*}{ Variable } & \multicolumn{5}{|c|}{ Financial Professionals } & \multicolumn{5}{|c|}{ Students } \\
\hline & \multicolumn{2}{|c|}{ WAVE 1} & \multicolumn{2}{|c|}{ WAVE 2} & \multirow[b]{2}{*}{$t$} & \multicolumn{2}{|c|}{ WAVE 1} & \multicolumn{2}{|c|}{ WAVE 2} & \multirow[b]{2}{*}{$t$} \\
\hline & Mean & (s.d.) & Mean & (s.d.) & & Mean & (s.d.) & Mean & (s.d.) & \\
\hline Age & 37.90 & $(8.49)$ & 39.23 & $(9.49)$ & 1.24 & 22.70 & $(3.06)$ & 23.19 & (3.34) & 1.70 \\
\hline Female & 0.13 & & 0.18 & & 1.08 & 0.46 & & 0.49 & & 0.57 \\
\hline Risk tolerance (general) & 7.60 & $(2.03)$ & 7.35 & $(2.20)$ & 1.01 & 6.69 & $(2.42)$ & 6.59 & $(2.34)$ & 0.47 \\
\hline Risk tolerance (financial) & 7.77 & $(2.06)$ & 7.61 & $(2.17)$ & 0.65 & 5.54 & $(2.44)$ & 5.45 & $(2.51)$ & 0.38 \\
\hline CRT2 & 1.38 & $(0.75)$ & 1.27 & $(0.71)$ & 1.30 & 1.06 & $(0.80)$ & 1.06 & $(0.86)$ & 0.06 \\
\hline Investment in fin. prod. & & & & & & 0.33 & & 0.33 & & \\
\hline \multicolumn{11}{|l|}{ Highest lev. of education: } \\
\hline Compulsory school & 0.00 & & 0.01 & & & 0.01 & & 0.01 & & \\
\hline Apprenticeship & 0.00 & & 0.03 & & & 0.00 & & 0.00 & & \\
\hline Technical college & 0.01 & & 0.00 & & & 0.02 & & 0.02 & & \\
\hline High school & 0.07 & & 0.16 & & & 0.55 & & 0.46 & & \\
\hline University & 0.90 & & 0.78 & & & 0.40 & & 0.47 & & \\
\hline Prefer not to say & 0.01 & & 0.03 & & & 0.01 & & 0.04 & & \\
\hline \multicolumn{11}{|l|}{ Job function: } \\
\hline Chief-Level Executive & 0.02 & & 0.01 & & & & & & & \\
\hline Consultant & 0.09 & & 0.14 & & & & & & & \\
\hline Financial Advisor & 0.12 & & 0.08 & & & & & & & \\
\hline Fund Manager & 0.06 & & 0.04 & & & & & & & \\
\hline Investment Management & 0.10 & & 0.12 & & & & & & & \\
\hline Portfolio Manager & 0.19 & & 0.15 & & & & & & & \\
\hline Research Analyst & 0.05 & & 0.06 & & & & & & & \\
\hline Trader & 0.10 & & 0.14 & & & & & & & \\
\hline \multirow[t]{2}{*}{ Other } & 0.26 & & 0.26 & & & & & & & \\
\hline & \multicolumn{2}{|c|}{$N=202$} & \multicolumn{2}{|c|}{$N=113$} & & \multicolumn{2}{|c|}{$N=282$} & \multicolumn{2}{|c|}{$N=216$} & \\
\hline
\end{tabular}


Table C2: Ordinary least squares regressions on INVESTMENT, RECOMMENDATION, and SATISFACTION, for each participant pool (financial professionals and students) and each presentation format (RETURNS Or PRICES) for the first occurrence of a shock only. POST_SHOCK is a dummy variable taking the value 1 for periods after the volatility shock (i.e., $t=3$ and $t=4$ ), zero otherwise, and PRE_SHOCK stands for a dummy variable taking the value 1 for periods before the shock (i.e., $t=1$ and $t=2$ ), zero otherwise. The interaction terms (e.g., POST_SHOCK $\times$ UP) measure the combined effects of the shock phase (i.e., before or after the shock) and the respective treatment (i.e., UP or DowN). All specifications are run with a participant's risk attitude, CRT score, age, and gender as control variables. Clustered standard errors at the participant-level are in parentheses. ${ }^{*}$ and ${ }^{* *}$ indicate the $5 \%$ - and 0.5\%-significance levels, respectively.

\begin{tabular}{|c|c|c|c|c|c|c|}
\hline \multirow[b]{2}{*}{ Finance Professionals } & \multicolumn{2}{|c|}{ Investment } & \multicolumn{2}{|c|}{ Recommendation } & \multicolumn{2}{|c|}{ Satisfaction } \\
\hline & $\begin{array}{l}\text { Prices } \\
\text { (1) }\end{array}$ & $\begin{array}{c}\text { Returns } \\
\text { (2) }\end{array}$ & $\begin{array}{l}\text { Prices } \\
\text { (3) }\end{array}$ & $\begin{array}{l}\text { Returns } \\
\text { (4) }\end{array}$ & $\begin{array}{l}\text { Prices } \\
\text { (5) }\end{array}$ & $\begin{array}{c}\text { Returns } \\
\text { (6) }\end{array}$ \\
\hline POST_SHOCK & $\begin{array}{c}1.524 \\
(1.888)\end{array}$ & $\begin{array}{c}2.063 \\
(1.164)\end{array}$ & $\begin{array}{c}-0.149 \\
(0.082)\end{array}$ & $\begin{array}{r}-0.179 \\
(0.108)\end{array}$ & $\begin{array}{c}-0.527^{* *} \\
(0.106)\end{array}$ & $\begin{array}{c}-0.987^{\text {*** }} \\
(0.185)\end{array}$ \\
\hline PRE_SHOCK $\times$ DOWN & $\begin{array}{c}-1.669 \\
(4.965)\end{array}$ & $\begin{array}{l}10.622^{*} \\
(4.721)\end{array}$ & $\begin{array}{c}-0.058 \\
(0.117)\end{array}$ & $\begin{array}{c}-0.162 \\
(0.113)\end{array}$ & $\begin{array}{r}-0.465^{*} \\
(0.196)\end{array}$ & $\begin{array}{c}-0.408 \\
(0.269)\end{array}$ \\
\hline POST_SHOCK $\times$ DOWN & $\begin{array}{c}3.182 \\
(5.223)\end{array}$ & $\begin{array}{l}14.176^{* *} \\
(4.641)\end{array}$ & $\begin{array}{c}0.419^{*} \\
(0.168)\end{array}$ & $\begin{array}{c}0.064 \\
(0.216)\end{array}$ & $\begin{array}{c}-1.157^{* *} \\
(0.243)\end{array}$ & $\begin{array}{c}-0.329 \\
(0.319)\end{array}$ \\
\hline PRE_SHOCK $\times$ UP & $\begin{array}{c}-0.036 \\
(4.886)\end{array}$ & $\begin{array}{c}3.668 \\
(5.161)\end{array}$ & $\begin{array}{c}-0.089 \\
(0.113)\end{array}$ & $\begin{array}{c}-0.090 \\
(0.098)\end{array}$ & $\begin{array}{c}0.028 \\
(0.184)\end{array}$ & $\begin{array}{c}-0.121 \\
(0.230)\end{array}$ \\
\hline POST_SHOCK $\times$ UP & $\begin{array}{c}-7.999 \\
(5.163)\end{array}$ & $\begin{array}{c}-3.891 \\
(5.771)\end{array}$ & $\begin{array}{c}-0.024 \\
(0.135)\end{array}$ & $\begin{array}{c}-0.051 \\
(0.158)\end{array}$ & $\begin{array}{c}1.305^{* *} \\
(0.243)\end{array}$ & $\begin{array}{c}1.491^{\text {** }} \\
(0.262)\end{array}$ \\
\hline Constant & $\begin{array}{c}38.842^{*} \\
(14.671)\end{array}$ & $\begin{array}{c}57.545^{* *} \\
(16.498)\end{array}$ & $\begin{array}{c}2.816^{* *} \\
(0.338)\end{array}$ & $\begin{array}{c}3.018^{* *} \\
(0.290)\end{array}$ & $\begin{array}{r}-0.551 \\
(0.673)\end{array}$ & $\begin{array}{c}0.617 \\
(0.615)\end{array}$ \\
\hline Controls & Yes & Yes & Yes & Yes & Yes & Yes \\
\hline Observations & 495 & 515 & 396 & 412 & 396 & 410 \\
\hline $\mathrm{R}^{2}$ & 0.223 & 0.198 & 0.077 & 0.040 & 0.199 & 0.127 \\
\hline Adjusted $\mathrm{R}^{2}$ & 0.207 & 0.182 & 0.053 & 0.016 & 0.179 & 0.105 \\
\hline Students & (7) & (8) & (9) & (10) & (11) & (12) \\
\hline POST_SHOCK & $\begin{array}{c}3.848 \\
(2.036)\end{array}$ & $\begin{array}{c}2.976 \\
(2.322)\end{array}$ & $\begin{array}{c}-0.044 \\
(0.081)\end{array}$ & $\begin{array}{r}-0.255^{*} \\
(0.099)\end{array}$ & $\begin{array}{c}-0.816^{* *} \\
(0.144)\end{array}$ & $\begin{array}{c}-0.950^{* *} \\
(0.129)\end{array}$ \\
\hline PRE_SHOCK $\times$ DOWN & $\begin{array}{c}4.979 \\
(4.180)\end{array}$ & $\begin{array}{c}3.802 \\
(4.629)\end{array}$ & $\begin{array}{c}-0.106 \\
(0.091)\end{array}$ & $\begin{array}{c}0.074 \\
(0.121)\end{array}$ & $\begin{array}{c}-0.465^{* *} \\
(0.158)\end{array}$ & $\begin{array}{c}-0.232 \\
(0.183)\end{array}$ \\
\hline POST_SHOCK $\times$ DOWN & $\begin{array}{c}1.655 \\
(4.810)\end{array}$ & $\begin{array}{c}0.922 \\
(5.296)\end{array}$ & $\begin{array}{c}-0.051 \\
(0.137)\end{array}$ & $\begin{array}{c}0.158 \\
(0.140)\end{array}$ & $\begin{array}{c}-0.831^{* *} \\
(0.186)\end{array}$ & $\begin{array}{c}0.070 \\
(0.200)\end{array}$ \\
\hline PRE_SHOCK $\times$ UP & $\begin{array}{c}-8.533 \\
(4.410)\end{array}$ & $\begin{array}{c}1.310 \\
(4.581)\end{array}$ & $\begin{array}{c}-0.148 \\
(0.111)\end{array}$ & $\begin{array}{c}-0.043 \\
(0.111)\end{array}$ & $\begin{array}{r}-0.125 \\
(0.201)\end{array}$ & $\begin{array}{c}-0.035 \\
(0.164)\end{array}$ \\
\hline POST_SHOCK $\times$ UP & $\begin{array}{c}-18.153^{* *} \\
(5.375)\end{array}$ & $\begin{array}{c}0.418 \\
(4.976)\end{array}$ & $\begin{array}{c}-0.378^{* *} \\
(0.126)\end{array}$ & $\begin{array}{c}0.335^{*} \\
(0.125)\end{array}$ & $\begin{array}{c}1.643^{* *} \\
(0.225)\end{array}$ & $\begin{array}{c}1.488^{* *} \\
(0.207)\end{array}$ \\
\hline Constant & $\begin{array}{c}25.081 \\
(12.985)\end{array}$ & $\begin{array}{c}37.196 * \\
(16.918)\end{array}$ & $\begin{array}{c}2.925^{* *} \\
(0.287)\end{array}$ & $\begin{array}{c}2.641^{* *} \\
(0.409)\end{array}$ & $\begin{array}{c}-0.350 \\
(0.526)\end{array}$ & $\begin{array}{r}-0.278 \\
(0.606)\end{array}$ \\
\hline Controls & Yes & Yes & Yes & Yes & Yes & Yes \\
\hline Observations & 660 & 750 & 528 & 600 & 527 & 596 \\
\hline $\mathrm{R}^{2}$ & 0.228 & 0.122 & 0.046 & 0.044 & 0.188 & 0.085 \\
\hline Adjusted $\mathrm{R}^{2}$ & 0.216 & 0.110 & 0.027 & 0.028 & 0.173 & 0.070 \\
\hline
\end{tabular}


Table C3: Ordinary least squares regressions on RISK PERCEPTION, PRICE FORECAST, and RETURN FORECAST, for each participant pool (financial professionals and students) and each presentation format (RETURNS or PRICES) for the first occurrence of a shock only. POST_SHOCK is a dummy variable taking the value 1 for periods after the volatility shock (i.e., $t=3$ and $t=4$ ), zero otherwise, and PRE_SHOCK stands for a dummy variable taking the value 1 for periods before the shock (i.e., $t=1$ and $t=2$ ), zero otherwise. The interaction terms (e.g., POST_SHOCK $\times$ UP) measure the combined effects of the shock phase (i.e., before or after the shock) and the respective treatment (i.e., UP or DOWN). All specifications are run with a participant's risk attitude, CRT score, age, and gender as control variables. Clustered standard errors at the participant-level are in parentheses. * and ${ }^{* *}$ indicate the 5\%- and $0.5 \%$-significance levels, respectively.

\begin{tabular}{|c|c|c|c|c|c|c|}
\hline \multirow[b]{2}{*}{ Finance Professionals } & \multicolumn{2}{|c|}{ Risk perception } & \multicolumn{2}{|c|}{ Price forecast } & \multicolumn{2}{|c|}{ Return forecast } \\
\hline & $\begin{array}{l}\text { Prices } \\
\text { (1) }\end{array}$ & $\begin{array}{l}\text { Returns } \\
\text { (2) }\end{array}$ & $\begin{array}{l}\text { Prices } \\
\text { (3) }\end{array}$ & $\begin{array}{l}\text { Returns } \\
\text { (4) }\end{array}$ & $\begin{array}{l}\text { Prices } \\
\text { (5) }\end{array}$ & $\begin{array}{l}\text { Returns } \\
\text { (6) }\end{array}$ \\
\hline POST_SHOCK & $\begin{array}{c}0.673^{* *} \\
(0.154)\end{array}$ & $\begin{array}{c}0.869^{* *} \\
(0.168)\end{array}$ & $\begin{array}{c}0.604 \\
(0.542)\end{array}$ & $\begin{array}{c}-0.237 \\
(0.307)\end{array}$ & $\begin{array}{c}0.925 \\
(0.574)\end{array}$ & $\begin{array}{c}0.236 \\
(0.186)\end{array}$ \\
\hline PRE_SHOCK $\times$ DOWN & $\begin{array}{c}-0.341 \\
(0.239)\end{array}$ & $\begin{array}{c}0.062 \\
(0.312)\end{array}$ & $\begin{array}{c}-3.066 \\
(2.873)\end{array}$ & $\begin{array}{c}0.294 \\
(0.397)\end{array}$ & $\begin{array}{c}-3.488 \\
(2.798)\end{array}$ & $\begin{array}{r}-0.353 \\
(0.355)\end{array}$ \\
\hline POST_SHOCK $\times$ DOWN & $\begin{array}{c}0.161 \\
(0.270)\end{array}$ & $\begin{array}{c}0.006 \\
(0.269)\end{array}$ & $\begin{array}{c}-17.889^{* *} \\
(2.454)\end{array}$ & $\begin{array}{c}-15.977^{* *} \\
(0.762)\end{array}$ & $\begin{array}{c}-0.470 \\
(2.773)\end{array}$ & $\begin{array}{c}0.999 \\
(0.784)\end{array}$ \\
\hline PRE_SHOCK $\times$ UP & $\begin{array}{c}-0.197 \\
(0.288)\end{array}$ & $\begin{array}{c}0.512 \\
(0.265)\end{array}$ & $\begin{array}{c}-2.158 \\
(4.370)\end{array}$ & $\begin{array}{c}0.555 \\
(0.317)\end{array}$ & $\begin{array}{c}-2.799 \\
(4.451)\end{array}$ & $\begin{array}{r}-0.233 \\
(0.273)\end{array}$ \\
\hline POST_SHOCK $\times$ UP & $\begin{array}{c}0.278 \\
(0.259)\end{array}$ & $\begin{array}{c}0.424 \\
(0.241)\end{array}$ & $\begin{array}{l}13.501^{* *} \\
(3.676)\end{array}$ & $\begin{array}{l}16.908^{* *} \\
(0.701)\end{array}$ & $\begin{array}{c}-2.924 \\
(3.223)\end{array}$ & $\begin{array}{r}-0.226 \\
(0.555)\end{array}$ \\
\hline Constant & $\begin{array}{c}3.048^{* *} \\
(0.634)\end{array}$ & $\begin{array}{c}4.517^{* *} \\
(0.685)\end{array}$ & $\begin{array}{l}97.863^{* *} \\
(6.694)\end{array}$ & $\begin{array}{l}98.560^{* *} \\
(1.183)\end{array}$ & $\begin{array}{c}-0.420 \\
(6.680)\end{array}$ & $\begin{array}{r}-0.011 \\
(0.986)\end{array}$ \\
\hline Controls & Yes & Yes & Yes & Yes & Yes & Yes \\
\hline Observations & 387 & 410 & 396 & 412 & 396 & 412 \\
\hline $\mathrm{R}^{2}$ & 0.174 & 0.142 & 0.284 & 0.910 & 0.070 & 0.098 \\
\hline Adjusted $\mathrm{R}^{2}$ & 0.152 & 0.121 & 0.265 & 0.908 & 0.046 & 0.075 \\
\hline Students & (7) & (8) & (9) & (10) & (11) & (12) \\
\hline POST_SHOCK & $\begin{array}{c}0.685^{* *} \\
(0.140)\end{array}$ & $\begin{array}{c}0.214 \\
(0.137)\end{array}$ & $\begin{array}{c}3.355^{*} \\
(1.222)\end{array}$ & $\begin{array}{r}-0.334 \\
(1.114)\end{array}$ & $\begin{array}{c}3.513^{* *} \\
(1.233)\end{array}$ & $\begin{array}{c}0.023 \\
(1.130)\end{array}$ \\
\hline PRE_SHOCK $\times$ DOWN & $\begin{array}{r}-0.553^{*} \\
(0.225)\end{array}$ & $\begin{array}{c}0.046 \\
(0.201)\end{array}$ & $\begin{array}{c}4.695 \\
(3.147)\end{array}$ & $\begin{array}{c}5.460 \\
(3.948)\end{array}$ & $\begin{array}{c}4.000 \\
(3.156)\end{array}$ & $\begin{array}{c}4.823 \\
(3.967)\end{array}$ \\
\hline POST_SHOCK $\times$ DOWN & $\begin{array}{c}-0.018 \\
(0.219)\end{array}$ & $\begin{array}{l}0.651^{\text {** }} \\
(0.209)\end{array}$ & $\begin{array}{c}-13.560^{* *} \\
(2.403)\end{array}$ & $\begin{array}{c}-16.210^{* *} \\
(3.050)\end{array}$ & $\begin{array}{c}4.021 \\
(2.715)\end{array}$ & $\begin{array}{c}1.803 \\
(3.540)\end{array}$ \\
\hline PRE_SHOCK $\times$ UP & $\begin{array}{c}-0.092 \\
(0.233)\end{array}$ & $\begin{array}{c}0.040 \\
(0.178)\end{array}$ & $\begin{array}{c}0.091 \\
(2.869)\end{array}$ & $\begin{array}{c}-0.996 \\
(2.598)\end{array}$ & $\begin{array}{c}-0.615 \\
(2.905)\end{array}$ & $\begin{array}{r}-1.753 \\
(2.577)\end{array}$ \\
\hline POST_SHOCK $\times$ UP & $\begin{array}{c}-0.408 \\
(0.252)\end{array}$ & $\begin{array}{c}-0.291 \\
(0.200)\end{array}$ & $\begin{array}{l}12.206^{* *} \\
(2.145)\end{array}$ & $\begin{array}{l}17.032^{* *} \\
(2.493)\end{array}$ & $\begin{array}{c}-3.663 \\
(1.986)\end{array}$ & $\begin{array}{r}-0.548 \\
(2.353)\end{array}$ \\
\hline Constant & $\begin{array}{c}4.480^{* *} \\
(0.692)\end{array}$ & $\begin{array}{c}4.361^{* *} \\
(0.696)\end{array}$ & $\begin{array}{c}90.094^{* *} \\
(10.172)\end{array}$ & $\begin{array}{c}120.447^{* *} \\
(9.597)\end{array}$ & $\begin{array}{c}-8.126 \\
(10.496)\end{array}$ & $\begin{array}{r}22.072^{*} \\
(10.297)\end{array}$ \\
\hline Controls & Yes & Yes & Yes & Yes & Yes & Yes \\
\hline Observations & 515 & 590 & 528 & 600 & 528 & 600 \\
\hline $\mathrm{R}^{2}$ & 0.112 & 0.060 & 0.208 & 0.302 & 0.063 & 0.072 \\
\hline Adjusted $\mathrm{R}^{2}$ & 0.094 & 0.043 & 0.192 & 0.290 & 0.045 & 0.056 \\
\hline
\end{tabular}


Table C4: Ordinary least squares regressions on INVESTMENT for each participant pool (financial professionals and students) and each presentation format (RETURNS or PRICES). $t$ indicates time period and UP and DOWN stand for the direction of the shock in the respective treatment. $t=2$ and the STRAIGHT path act as the reference categories. Controls include a participant's risk tolerance, CRT score, age, and gender. Clustered standard errors on the participant-level are in parentheses. ${ }^{*}$ and ${ }^{* *}$ indicate the 5\%- and the $0.5 \%$-significance levels, respectively.

\begin{tabular}{|c|c|c|c|c|c|c|c|c|}
\hline & \multicolumn{8}{|c|}{ Dependent variable: INVESTMENT } \\
\hline & \multicolumn{4}{|c|}{ Financial Professionals } & \multicolumn{4}{|c|}{ Students } \\
\hline & \multicolumn{2}{|c|}{ PRICES } & \multicolumn{2}{|c|}{ RETURNS } & \multicolumn{2}{|c|}{ PRICES } & \multicolumn{2}{|c|}{ RETURNS } \\
\hline & (1) & (2) & (3) & (4) & (5) & (6) & (7) & (8) \\
\hline$t=1$ & $\begin{array}{c}-0.324 \\
(2.080)\end{array}$ & $\begin{array}{c}-0.324 \\
(2.084)\end{array}$ & $\begin{array}{c}2.947 \\
(2.263)\end{array}$ & $\begin{array}{c}2.947 \\
(2.268)\end{array}$ & $\begin{array}{r}-4.259^{*} \\
(1.620)\end{array}$ & $\begin{array}{r}-4.259^{*} \\
(1.623)\end{array}$ & $\begin{array}{c}0.006 \\
(1.922)\end{array}$ & $\begin{array}{c}0.006 \\
(1.925)\end{array}$ \\
\hline$t=3$ & $\begin{array}{c}0.575 \\
(2.110)\end{array}$ & $\begin{array}{c}0.575 \\
(2.114)\end{array}$ & $\begin{array}{c}0.630 \\
(1.633)\end{array}$ & $\begin{array}{c}0.630 \\
(1.637)\end{array}$ & $\begin{array}{c}-0.876 \\
(1.298)\end{array}$ & $\begin{array}{c}-0.876 \\
(1.300)\end{array}$ & $\begin{array}{c}-0.901 \\
(1.965)\end{array}$ & $\begin{array}{c}-0.901 \\
(1.968)\end{array}$ \\
\hline$t=4$ & $\begin{array}{c}1.104 \\
(2.551)\end{array}$ & $\begin{array}{c}1.104 \\
(2.557)\end{array}$ & $\begin{array}{c}2.601 \\
(2.036)\end{array}$ & $\begin{array}{c}2.601 \\
(2.041)\end{array}$ & $\begin{array}{c}-0.140 \\
(1.732)\end{array}$ & $\begin{array}{c}-0.140 \\
(1.734)\end{array}$ & $\begin{array}{c}4.046^{*} \\
(2.012)\end{array}$ & $\begin{array}{r}4.046^{*} \\
(2.015)\end{array}$ \\
\hline$t=2 \times$ DOWN & $\begin{array}{c}-3.877 \\
(2.880)\end{array}$ & $\begin{array}{c}-3.877 \\
(2.886)\end{array}$ & $\begin{array}{r}3.985^{*} \\
(1.997)\end{array}$ & $\begin{array}{c}3.985^{*} \\
(2.001)\end{array}$ & $\begin{array}{c}2.913 \\
(1.839)\end{array}$ & $\begin{array}{c}2.913 \\
(1.842)\end{array}$ & $\begin{array}{c}2.311 \\
(2.296)\end{array}$ & $\begin{array}{c}2.311 \\
(2.299)\end{array}$ \\
\hline$t=1 \times$ DOWN & $\begin{array}{c}-1.990 \\
(2.699)\end{array}$ & $\begin{array}{c}-1.990 \\
(2.705)\end{array}$ & $\begin{array}{c}-1.147 \\
(2.005)\end{array}$ & $\begin{array}{r}-1.147 \\
(2.010)\end{array}$ & $\begin{array}{c}3.205 \\
(2.101)\end{array}$ & $\begin{array}{c}3.205 \\
(2.104)\end{array}$ & $\begin{array}{c}-0.585 \\
(2.244)\end{array}$ & $\begin{array}{r}-0.585 \\
(2.247)\end{array}$ \\
\hline$t=3 \times$ DOWN & $\begin{array}{c}5.273^{* *} \\
(1.836)\end{array}$ & $\begin{array}{c}5.273^{* *} \\
(1.840)\end{array}$ & $\begin{array}{c}7.229^{*} \\
(2.584)\end{array}$ & $\begin{array}{c}7.229^{*} \\
(2.590)\end{array}$ & $\begin{array}{c}1.919 \\
(2.503)\end{array}$ & $\begin{array}{c}1.919 \\
(2.507)\end{array}$ & $\begin{array}{c}2.066 \\
(2.429)\end{array}$ & $\begin{array}{c}2.066 \\
(2.432)\end{array}$ \\
\hline$t=4 \times$ DOWN & $\begin{array}{c}4.659^{*} \\
(2.227)\end{array}$ & $\begin{array}{c}4.659^{*} \\
(2.232)\end{array}$ & $\begin{array}{c}5.694^{*} \\
(2.210)\end{array}$ & $\begin{array}{c}5.694^{*} \\
(2.215)\end{array}$ & $\begin{array}{c}2.781 \\
(2.107)\end{array}$ & $\begin{array}{c}2.781 \\
(2.110)\end{array}$ & $\begin{array}{c}-0.764 \\
(1.882)\end{array}$ & $\begin{array}{c}-0.764 \\
(1.885)\end{array}$ \\
\hline$t=2 \times \mathrm{UP}$ & $\begin{array}{c}-0.315 \\
(2.269)\end{array}$ & $\begin{array}{c}-0.315 \\
(2.274)\end{array}$ & $\begin{array}{c}2.296 \\
(2.538)\end{array}$ & $\begin{array}{c}2.296 \\
(2.543)\end{array}$ & $\begin{array}{c}-2.900 \\
(2.521)\end{array}$ & $\begin{array}{c}-2.900 \\
(2.525)\end{array}$ & $\begin{array}{c}-1.857 \\
(2.289)\end{array}$ & $\begin{array}{c}-1.857 \\
(2.292)\end{array}$ \\
\hline$t=1 \times \mathrm{UP}$ & $\begin{array}{c}1.757 \\
(2.366)\end{array}$ & $\begin{array}{c}1.757 \\
(2.371)\end{array}$ & $\begin{array}{c}0.670 \\
(1.856)\end{array}$ & $\begin{array}{c}0.670 \\
(1.860)\end{array}$ & $\begin{array}{c}2.959 \\
(2.343)\end{array}$ & $\begin{array}{c}2.959 \\
(2.346)\end{array}$ & $\begin{array}{c}0.087 \\
(1.870)\end{array}$ & $\begin{array}{c}0.087 \\
(1.873)\end{array}$ \\
\hline$t=3 \times \mathrm{UP}$ & $\begin{array}{c}-9.656^{* *} \\
(2.743)\end{array}$ & $\begin{array}{c}-9.656^{* *} \\
(2.749)\end{array}$ & $\begin{array}{r}-8.624^{*} \\
(3.158)\end{array}$ & $\begin{array}{r}-8.624^{*} \\
(3.164)\end{array}$ & $\begin{array}{c}-4.054 \\
(2.259)\end{array}$ & $\begin{array}{c}-4.054 \\
(2.262)\end{array}$ & $\begin{array}{r}-4.434^{*} \\
(2.251)\end{array}$ & $\begin{array}{r}-4.434^{*} \\
(2.255)\end{array}$ \\
\hline$t=4 \times \mathrm{UP}$ & $\begin{array}{r}-5.732^{*} \\
(2.686)\end{array}$ & $\begin{array}{r}-5.732^{*} \\
(2.692)\end{array}$ & $\begin{array}{c}-3.124 \\
(2.559)\end{array}$ & $\begin{array}{c}-3.124 \\
(2.564)\end{array}$ & $\begin{array}{r}-4.973^{*} \\
(2.351)\end{array}$ & $\begin{array}{r}-4.973^{*} \\
(2.354)\end{array}$ & $\begin{array}{c}-1.926 \\
(1.819)\end{array}$ & $\begin{array}{c}-1.926 \\
(1.821)\end{array}$ \\
\hline Constant & $\begin{array}{l}74.727^{* *} \\
(2.669)\end{array}$ & $\begin{array}{r}35.968^{*} \\
(15.529)\end{array}$ & $\begin{array}{c}77.539^{* *} \\
(2.669)\end{array}$ & $\begin{array}{c}61.851^{\text {** }} \\
(16.582)\end{array}$ & $\begin{array}{l}56.946^{* *} \\
(2.425)\end{array}$ & $\begin{array}{c}11.364 \\
(14.122)\end{array}$ & $\begin{array}{l}58.034^{* *} \\
(2.460)\end{array}$ & $\begin{array}{r}42.416^{*} \\
(18.402)\end{array}$ \\
\hline Controls & No & Yes & No & Yes & No & Yes & No & Yes \\
\hline Observations & 1,188 & 1,188 & 1,236 & 1,236 & 1,584 & 1,584 & 1,800 & 1,800 \\
\hline $\mathrm{R}^{2}$ & 0.023 & 0.185 & 0.024 & 0.131 & 0.008 & 0.176 & 0.006 & 0.156 \\
\hline Adjusted $\mathrm{R}^{2}$ & 0.013 & 0.174 & 0.015 & 0.119 & 0.001 & 0.167 & 0.00003 & 0.148 \\
\hline
\end{tabular}


Table C5: Ordinary least squares regressions on RECOMMENDATION for each participant pool (financial professionals and students) and each presentation format (RETURNS or PRICES). $t$ indicates time period and UP and DOWN stand for the direction of the shock in the respective treatment. $t=2$ and the STRAIGHT path act as the reference categories. Controls include a participant's risk tolerance, CRT score, age, and gender. Clustered standard errors on the participant-level are in parentheses. ${ }^{*}$ and ${ }^{* *}$ indicate the 5\%- and the $0.5 \%$-significance levels, respectively.

\begin{tabular}{|c|c|c|c|c|c|c|c|c|}
\hline & \multicolumn{8}{|c|}{ Dependent variable: RECOMMENDATION } \\
\hline & \multicolumn{4}{|c|}{ Financial Professionals } & \multicolumn{4}{|c|}{ Students } \\
\hline & \multicolumn{2}{|c|}{ PRICES } & \multicolumn{2}{|c|}{ RETURNS } & \multicolumn{2}{|c|}{ PRICES } & \multicolumn{2}{|c|}{ RETURNS } \\
\hline & (1) & (2) & (3) & (4) & (5) & (6) & (7) & (8) \\
\hline$t=1$ & $\begin{array}{c}-0.061 \\
(0.076)\end{array}$ & $\begin{array}{c}-0.061 \\
(0.076)\end{array}$ & $\begin{array}{r}-0.175^{*} \\
(0.066)\end{array}$ & $\begin{array}{r}-0.175^{*} \\
(0.066)\end{array}$ & $\begin{array}{c}0.015 \\
(0.086)\end{array}$ & $\begin{array}{c}0.015 \\
(0.086)\end{array}$ & $\begin{array}{c}-0.140 \\
(0.100)\end{array}$ & $\begin{array}{c}-0.140 \\
(0.100)\end{array}$ \\
\hline$t=3$ & $\begin{array}{r}-0.152^{*} \\
(0.077)\end{array}$ & $\begin{array}{c}-0.152^{*} \\
(0.077)\end{array}$ & $\begin{array}{c}-0.388^{* *} \\
(0.087)\end{array}$ & $\begin{array}{c}-0.388^{* *} \\
(0.087)\end{array}$ & $\begin{array}{c}-0.114 \\
(0.085)\end{array}$ & $\begin{array}{c}-0.114 \\
(0.085)\end{array}$ & $\begin{array}{c}-0.327^{* *} \\
(0.092)\end{array}$ & $\begin{array}{c}-0.327^{* *} \\
(0.092)\end{array}$ \\
\hline$t=4$ & $\begin{array}{c}-0.121 \\
(0.073)\end{array}$ & $\begin{array}{c}-0.121 \\
(0.073)\end{array}$ & $\begin{array}{c}-0.194^{*} \\
(0.088)\end{array}$ & $\begin{array}{r}-0.194^{*} \\
(0.088)\end{array}$ & $\begin{array}{r}-0.159^{*} \\
(0.081)\end{array}$ & $\begin{array}{r}-0.159^{*} \\
(0.081)\end{array}$ & $\begin{array}{c}-0.293^{* *} \\
(0.092)\end{array}$ & $\begin{array}{c}-0.293^{* *} \\
(0.092)\end{array}$ \\
\hline$t=2 \times$ DOWN & $\begin{array}{c}-0.071 \\
(0.071)\end{array}$ & $\begin{array}{c}-0.071 \\
(0.071)\end{array}$ & $\begin{array}{c}-0.107 \\
(0.071)\end{array}$ & $\begin{array}{c}-0.107 \\
(0.071)\end{array}$ & $\begin{array}{c}0.015 \\
(0.086)\end{array}$ & $\begin{array}{c}0.015 \\
(0.086)\end{array}$ & $\begin{array}{c}0.000 \\
(0.091)\end{array}$ & $\begin{array}{c}0.000 \\
(0.091)\end{array}$ \\
\hline$t=1 \times$ DOWN & $\begin{array}{c}0.030 \\
(0.077)\end{array}$ & $\begin{array}{c}0.030 \\
(0.077)\end{array}$ & $\begin{array}{c}0.165^{*} \\
(0.076)\end{array}$ & $\begin{array}{c}0.165^{*} \\
(0.076)\end{array}$ & $\begin{array}{r}-0.030 \\
(0.086)\end{array}$ & $\begin{array}{c}-0.030 \\
(0.086)\end{array}$ & $\begin{array}{c}0.060 \\
(0.084)\end{array}$ & $\begin{array}{c}0.060 \\
(0.085)\end{array}$ \\
\hline$t=3 \times$ DOWN & $\begin{array}{c}0.434^{* *} \\
(0.097)\end{array}$ & $\begin{array}{c}0.434^{* *} \\
(0.097)\end{array}$ & $\begin{array}{c}0.311^{*} \\
(0.122)\end{array}$ & $\begin{array}{c}0.311^{*} \\
(0.122)\end{array}$ & $\begin{array}{c}0.288^{*} \\
(0.113)\end{array}$ & $\begin{array}{c}0.288^{*} \\
(0.114)\end{array}$ & $\begin{array}{c}-0.133 \\
(0.103)\end{array}$ & $\begin{array}{c}-0.133 \\
(0.104)\end{array}$ \\
\hline$t=4 \times$ DOWN & $\begin{array}{c}0.303^{* *} \\
(0.091)\end{array}$ & $\begin{array}{c}0.303^{* *} \\
(0.091)\end{array}$ & $\begin{array}{c}0.301^{* *} \\
(0.094)\end{array}$ & $\begin{array}{c}0.301^{* *} \\
(0.094)\end{array}$ & $\begin{array}{c}0.144^{*} \\
(0.067)\end{array}$ & $\begin{array}{c}0.144^{*} \\
(0.067)\end{array}$ & $\begin{array}{c}0.267^{* *} \\
(0.084)\end{array}$ & $\begin{array}{c}0.267^{* *} \\
(0.084)\end{array}$ \\
\hline$t=2 \times \mathrm{UP}$ & $\begin{array}{c}-0.051 \\
(0.065)\end{array}$ & $\begin{array}{c}-0.051 \\
(0.065)\end{array}$ & $\begin{array}{c}-0.078 \\
(0.070)\end{array}$ & $\begin{array}{c}-0.078 \\
(0.070)\end{array}$ & $\begin{array}{r}-0.189^{*} \\
(0.080)\end{array}$ & $\begin{array}{r}-0.189^{*} \\
(0.080)\end{array}$ & $\begin{array}{c}-0.113 \\
(0.088)\end{array}$ & $\begin{array}{c}-0.113 \\
(0.088)\end{array}$ \\
\hline$t=1 \times \mathrm{UP}$ & $\begin{array}{c}-0.020 \\
(0.074)\end{array}$ & $\begin{array}{c}-0.020 \\
(0.074)\end{array}$ & $\begin{array}{c}0.039 \\
(0.068)\end{array}$ & $\begin{array}{c}0.039 \\
(0.068)\end{array}$ & $\begin{array}{c}0.000 \\
(0.086)\end{array}$ & $\begin{array}{c}0.000 \\
(0.086)\end{array}$ & $\begin{array}{c}0.167^{*} \\
(0.077)\end{array}$ & $\begin{array}{c}0.167^{*} \\
(0.077)\end{array}$ \\
\hline$t=3 \times \mathrm{UP}$ & $\begin{array}{c}-0.172 \\
(0.104)\end{array}$ & $\begin{array}{c}-0.172 \\
(0.104)\end{array}$ & $\begin{array}{c}0.019 \\
(0.116)\end{array}$ & $\begin{array}{c}0.019 \\
(0.116)\end{array}$ & $\begin{array}{c}-0.394^{* *} \\
(0.124)\end{array}$ & $\begin{array}{c}-0.394^{* *} \\
(0.125)\end{array}$ & $\begin{array}{c}0.300^{*} \\
(0.122)\end{array}$ & $\begin{array}{r}0.300^{*} \\
(0.122)\end{array}$ \\
\hline$t=4 \times \mathrm{UP}$ & $\begin{array}{c}-0.141 \\
(0.076)\end{array}$ & $\begin{array}{c}-0.141 \\
(0.077)\end{array}$ & $\begin{array}{c}0.019 \\
(0.093)\end{array}$ & $\begin{array}{c}0.019 \\
(0.093)\end{array}$ & $\begin{array}{c}-0.015 \\
(0.059)\end{array}$ & $\begin{array}{c}-0.015 \\
(0.059)\end{array}$ & $\begin{array}{c}0.220^{* *} \\
(0.078)\end{array}$ & $\begin{array}{c}0.220^{* *} \\
(0.078)\end{array}$ \\
\hline Constant & $\begin{array}{c}3.253^{* *} \\
(0.057)\end{array}$ & $\begin{array}{c}3.137^{* *} \\
(0.264)\end{array}$ & $\begin{array}{c}3.291^{* *} \\
(0.053)\end{array}$ & $\begin{array}{c}3.151^{* *} \\
(0.285)\end{array}$ & $\begin{array}{c}3.000^{* *} \\
(0.058)\end{array}$ & $\begin{array}{c}2.754^{* *} \\
(0.165)\end{array}$ & $\begin{array}{c}2.867^{* *} \\
(0.068)\end{array}$ & $\begin{array}{c}2.621^{* *} \\
(0.309)\end{array}$ \\
\hline Controls & No & Yes & No & Yes & No & Yes & No & Yes \\
\hline Observations & 1,188 & 1,188 & 1,236 & 1,236 & 1,584 & 1,584 & 1,800 & 1,800 \\
\hline $\mathrm{R}^{2}$ & 0.051 & 0.072 & 0.031 & 0.060 & 0.041 & 0.050 & 0.027 & 0.043 \\
\hline Adjusted $\mathrm{R}^{2}$ & 0.043 & 0.059 & 0.022 & 0.048 & 0.034 & 0.040 & 0.021 & 0.035 \\
\hline
\end{tabular}


Table C6: Ordinary least squares regressions on SATISFACTION for each participant pool (financial professionals and students) and each presentation format (RETURNS or PRICES). $t$ indicates time period and UP and DOWN stand for the direction of the shock in the respective treatment. $t=2$ and the STRAIGHT path act as the reference categories. Controls include a participant's risk tolerance, CRT score, age, and gender. Clustered standard errors on the participant-level are in parentheses. ${ }^{*}$ and ${ }^{* *}$ indicate the $5 \%$ - and the $0.5 \%$-significance levels, respectively.

\begin{tabular}{|c|c|c|c|c|c|c|c|c|}
\hline & \multicolumn{8}{|c|}{ Dependent variable: SATISFACTION } \\
\hline & \multicolumn{4}{|c|}{ Financial Professionals } & \multicolumn{4}{|c|}{ Students } \\
\hline & \multicolumn{2}{|c|}{ PRICES } & \multicolumn{2}{|c|}{ RETURNS } & \multicolumn{2}{|c|}{ PRICES } & \multicolumn{2}{|c|}{ RETURNS } \\
\hline & (1) & (2) & (3) & (4) & (5) & (6) & (7) & (8) \\
\hline$t=1$ & $\begin{array}{c}-1.970^{* *} \\
(0.138)\end{array}$ & $\begin{array}{c}-1.970^{* *} \\
(0.138)\end{array}$ & $\begin{array}{c}-2.040^{* *} \\
(0.197)\end{array}$ & $\begin{array}{c}-2.042^{* *} \\
(0.197)\end{array}$ & $\begin{array}{c}-2.360^{* *} \\
(0.135)\end{array}$ & $\begin{array}{c}-2.359^{* *} \\
(0.135)\end{array}$ & $\begin{array}{c}-2.397^{* *} \\
(0.133)\end{array}$ & $\begin{array}{c}-2.397^{* *} \\
(0.133)\end{array}$ \\
\hline$t=3$ & $\begin{array}{c}-1.515^{* *} \\
(0.132)\end{array}$ & $\begin{array}{c}-1.515^{* *} \\
(0.133)\end{array}$ & $\begin{array}{c}-1.894^{* *} \\
(0.190)\end{array}$ & $\begin{array}{c}-1.896^{* *} \\
(0.190)\end{array}$ & $\begin{array}{c}-1.811^{* *} \\
(0.147)\end{array}$ & $\begin{array}{c}-1.811^{* *} \\
(0.147)\end{array}$ & $\begin{array}{c}-1.987^{* *} \\
(0.123)\end{array}$ & $\begin{array}{c}-1.987^{* *} \\
(0.124)\end{array}$ \\
\hline$t=4$ & $\begin{array}{c}-1.434^{* *} \\
(0.122)\end{array}$ & $\begin{array}{c}-1.434^{* *} \\
(0.122)\end{array}$ & $\begin{array}{c}-1.948^{* *} \\
(0.181)\end{array}$ & $\begin{array}{c}-1.955^{* *} \\
(0.181)\end{array}$ & $\begin{array}{c}-2.016^{* *} \\
(0.138)\end{array}$ & $\begin{array}{c}-2.017^{* *} \\
(0.138)\end{array}$ & $\begin{array}{c}-2.260^{* *} \\
(0.129)\end{array}$ & $\begin{array}{c}-2.260^{* *} \\
(0.129)\end{array}$ \\
\hline$t=2 \times$ DOWN & $\begin{array}{c}-1.202^{* *} \\
(0.152)\end{array}$ & $\begin{array}{c}-1.202^{* *} \\
(0.152)\end{array}$ & $\begin{array}{c}-1.555^{* *} \\
(0.210)\end{array}$ & $\begin{array}{c}-1.556^{* *} \\
(0.211)\end{array}$ & $\begin{array}{c}-1.566^{* *} \\
(0.160)\end{array}$ & $\begin{array}{c}-1.565^{* *} \\
(0.161)\end{array}$ & $\begin{array}{c}-1.558^{* *} \\
(0.151)\end{array}$ & $\begin{array}{c}-1.558^{* *} \\
(0.151)\end{array}$ \\
\hline$t=1 \times$ DOWN & $\begin{array}{c}1.081^{* *} \\
(0.154)\end{array}$ & $\begin{array}{c}1.081^{* *} \\
(0.155)\end{array}$ & $\begin{array}{c}1.259^{* *} \\
(0.204)\end{array}$ & $\begin{array}{c}1.261^{* *} \\
(0.204)\end{array}$ & $\begin{array}{c}1.252^{* *} \\
(0.157)\end{array}$ & $\begin{array}{c}1.252^{* *} \\
(0.157)\end{array}$ & $\begin{array}{c}1.037^{* *} \\
(0.145)\end{array}$ & $\begin{array}{c}1.037^{* *} \\
(0.145)\end{array}$ \\
\hline$t=3 \times$ DOWN & $\begin{array}{c}-1.677^{* *} \\
(0.146)\end{array}$ & $\begin{array}{c}-1.677^{* *} \\
(0.146)\end{array}$ & $\begin{array}{c}-1.233^{* *} \\
(0.154)\end{array}$ & $\begin{array}{c}-1.233^{* *} \\
(0.154)\end{array}$ & $\begin{array}{c}-1.674^{* *} \\
(0.134)\end{array}$ & $\begin{array}{c}-1.674^{* *} \\
(0.134)\end{array}$ & $\begin{array}{c}-1.500^{* *} \\
(0.132)\end{array}$ & $\begin{array}{c}-1.500^{* *} \\
(0.133)\end{array}$ \\
\hline$t=4 \times$ DOWN & $\begin{array}{c}0.343^{*} \\
(0.137)\end{array}$ & $\begin{array}{c}0.342^{*} \\
(0.137)\end{array}$ & $\begin{array}{c}0.752^{* *} \\
(0.163)\end{array}$ & $\begin{array}{c}0.753^{* *} \\
(0.164)\end{array}$ & $\begin{array}{c}0.501^{* *} \\
(0.132)\end{array}$ & $\begin{array}{c}0.502^{* *} \\
(0.132)\end{array}$ & $\begin{array}{c}1.347^{* *} \\
(0.115)\end{array}$ & $\begin{array}{c}1.347^{* *} \\
(0.115)\end{array}$ \\
\hline$t=2 \times \mathrm{UP}$ & $\begin{array}{c}-0.788^{* *} \\
(0.139)\end{array}$ & $\begin{array}{c}-0.788^{* *} \\
(0.140)\end{array}$ & $\begin{array}{c}-0.923^{* *} \\
(0.172)\end{array}$ & $\begin{array}{c}-0.925^{* *} \\
(0.172)\end{array}$ & $\begin{array}{c}-1.068^{* *} \\
(0.165)\end{array}$ & $\begin{array}{c}-1.068^{* *} \\
(0.165)\end{array}$ & $\begin{array}{c}-0.907^{* *} \\
(0.144)\end{array}$ & $\begin{array}{c}-0.907^{* *} \\
(0.144)\end{array}$ \\
\hline$t=1 \times \mathrm{UP}$ & $\begin{array}{c}0.960^{* *} \\
(0.157)\end{array}$ & $\begin{array}{c}0.960^{* *} \\
(0.158)\end{array}$ & $\begin{array}{c}0.716^{* *} \\
(0.169)\end{array}$ & $\begin{array}{c}0.716^{* *} \\
(0.170)\end{array}$ & $\begin{array}{c}1.003^{* *} \\
(0.169)\end{array}$ & $\begin{array}{c}1.003^{* *} \\
(0.169)\end{array}$ & $\begin{array}{c}0.826^{* *} \\
(0.134)\end{array}$ & $\begin{array}{c}0.825^{* *} \\
(0.134)\end{array}$ \\
\hline$t=3 \times \mathrm{UP}$ & $\begin{array}{c}2.179^{* *} \\
(0.165)\end{array}$ & $\begin{array}{c}2.181^{* *} \\
(0.165)\end{array}$ & $\begin{array}{c}2.291^{* *} \\
(0.220)\end{array}$ & $\begin{array}{c}2.291^{* *} \\
(0.220)\end{array}$ & $\begin{array}{c}2.682^{* *} \\
(0.198)\end{array}$ & $\begin{array}{c}2.682^{* *} \\
(0.198)\end{array}$ & $\begin{array}{c}2.760^{* *} \\
(0.158)\end{array}$ & $\begin{array}{c}2.761^{* *} \\
(0.158)\end{array}$ \\
\hline$t=4 \times \mathrm{UP}$ & $\begin{array}{c}0.606^{* *} \\
(0.132)\end{array}$ & $\begin{array}{c}0.606^{* *} \\
(0.132)\end{array}$ & $\begin{array}{c}0.595^{* *} \\
(0.139)\end{array}$ & $\begin{array}{c}0.601^{* *} \\
(0.139)\end{array}$ & $\begin{array}{c}0.577^{* *} \\
(0.128)\end{array}$ & $\begin{array}{c}0.578^{* *} \\
(0.128)\end{array}$ & $\begin{array}{c}0.333^{* *} \\
(0.108)\end{array}$ & $\begin{array}{c}0.333^{* *} \\
(0.108)\end{array}$ \\
\hline Constant & $\begin{array}{c}1.061^{* *} \\
(0.102)\end{array}$ & $\begin{array}{c}0.320 \\
(0.532)\end{array}$ & $\begin{array}{c}1.118^{* *} \\
(0.137)\end{array}$ & $\begin{array}{c}1.645^{* *} \\
(0.519)\end{array}$ & $\begin{array}{c}0.902^{* *} \\
(0.092)\end{array}$ & $\begin{array}{c}0.260 \\
(0.396)\end{array}$ & $\begin{array}{c}0.913^{* *} \\
(0.103)\end{array}$ & $\begin{array}{c}0.652 \\
(0.477)\end{array}$ \\
\hline Controls & No & Yes & No & Yes & No & Yes & No & Yes \\
\hline Observations & 1,186 & 1,186 & 1,227 & 1,227 & 1,580 & 1,580 & 1,794 & 1,794 \\
\hline $\mathrm{R}^{2}$ & 0.353 & 0.361 & 0.258 & 0.270 & 0.378 & 0.384 & 0.393 & 0.394 \\
\hline Adjusted $\mathrm{R}^{2}$ & 0.347 & 0.353 & 0.251 & 0.261 & 0.374 & 0.377 & 0.389 & 0.389 \\
\hline
\end{tabular}


Table C7: Ordinary least squares regressions on RISK PERCEPTION for each participant pool (financial professionals and students) and each presentation format (RETURNS or PRICES). $t$ indicates time period and UP and DOWN stand for the direction of the shock in the respective treatment. $t=2$ and the STRAIGHT path act as the reference categories. Controls include a participant's risk tolerance, CRT score, age, and gender. Clustered standard errors on the participant-level are in parentheses. ${ }^{*}$ and ${ }^{* *}$ indicate the 5\%- and the $0.5 \%$-significance levels, respectively.

\begin{tabular}{|c|c|c|c|c|c|c|c|c|}
\hline & \multicolumn{8}{|c|}{ Dependent variable: RISK PERCEPTION } \\
\hline & \multicolumn{4}{|c|}{ Financial Professionals } & \multicolumn{4}{|c|}{ Students } \\
\hline & \multicolumn{2}{|c|}{ PRICES } & \multicolumn{2}{|c|}{ RETURNS } & \multicolumn{2}{|c|}{ PRICES } & \multicolumn{2}{|c|}{ RETURNS } \\
\hline & (1) & (2) & (3) & (4) & (5) & (6) & (7) & (8) \\
\hline$t=1$ & $\begin{array}{c}-0.051 \\
(0.081)\end{array}$ & $\begin{array}{c}-0.046 \\
(0.082)\end{array}$ & $\begin{array}{c}-0.169 \\
(0.092)\end{array}$ & $\begin{array}{c}-0.162 \\
(0.093)\end{array}$ & $\begin{array}{r}0.216^{*} \\
(0.095)\end{array}$ & $\begin{array}{r}0.218^{*} \\
(0.095)\end{array}$ & $\begin{array}{c}0.318^{* *} \\
(0.108)\end{array}$ & $\begin{array}{c}0.322^{* *} \\
(0.107)\end{array}$ \\
\hline$t=3$ & $\begin{array}{c}1.204^{* *} \\
(0.119)\end{array}$ & $\begin{array}{c}1.201^{* *} \\
(0.120)\end{array}$ & $\begin{array}{c}0.912^{* *} \\
(0.116)\end{array}$ & $\begin{array}{c}0.916^{* *} \\
(0.116)\end{array}$ & $\begin{array}{c}1.407^{* *} \\
(0.113)\end{array}$ & $\begin{array}{c}1.407^{* *} \\
(0.114)\end{array}$ & $\begin{array}{c}0.757^{* *} \\
(0.101)\end{array}$ & $\begin{array}{c}0.760^{* *} \\
(0.101)\end{array}$ \\
\hline$t=4$ & $\begin{array}{c}0.482^{* *} \\
(0.106)\end{array}$ & $\begin{array}{c}0.487^{* *} \\
(0.106)\end{array}$ & $\begin{array}{c}-0.053 \\
(0.143)\end{array}$ & $\begin{array}{c}-0.056 \\
(0.144)\end{array}$ & $\begin{array}{c}0.178 \\
(0.128)\end{array}$ & $\begin{array}{c}0.178 \\
(0.128)\end{array}$ & $\begin{array}{c}-0.074 \\
(0.131)\end{array}$ & $\begin{array}{c}-0.073 \\
(0.131)\end{array}$ \\
\hline$t=2 \times$ DOWN & $\begin{array}{c}-0.023 \\
(0.109)\end{array}$ & $\begin{array}{c}-0.019 \\
(0.110)\end{array}$ & $\begin{array}{c}-0.206 \\
(0.144)\end{array}$ & $\begin{array}{c}-0.203 \\
(0.144)\end{array}$ & $\begin{array}{r}-0.334^{*} \\
(0.145)\end{array}$ & $\begin{array}{r}-0.333^{*} \\
(0.145)\end{array}$ & $\begin{array}{c}0.027 \\
(0.116)\end{array}$ & $\begin{array}{c}0.029 \\
(0.116)\end{array}$ \\
\hline$t=1 \times$ DOWN & $\begin{array}{c}-0.112 \\
(0.113)\end{array}$ & $\begin{array}{c}-0.111 \\
(0.113)\end{array}$ & $\begin{array}{c}-0.109 \\
(0.122)\end{array}$ & $\begin{array}{c}-0.113 \\
(0.123)\end{array}$ & $\begin{array}{c}-0.527^{* *} \\
(0.126)\end{array}$ & $\begin{array}{c}-0.528^{* *} \\
(0.126)\end{array}$ & $\begin{array}{c}-0.394^{* *} \\
(0.113)\end{array}$ & $\begin{array}{c}-0.396^{* *} \\
(0.113)\end{array}$ \\
\hline$t=3 \times$ DOWN & $\begin{array}{c}0.256^{*} \\
(0.127)\end{array}$ & $\begin{array}{c}0.257^{*} \\
(0.127)\end{array}$ & $\begin{array}{c}0.118 \\
(0.108)\end{array}$ & $\begin{array}{c}0.121 \\
(0.108)\end{array}$ & $\begin{array}{c}0.175 \\
(0.121)\end{array}$ & $\begin{array}{c}0.174 \\
(0.121)\end{array}$ & $\begin{array}{c}0.541^{* *} \\
(0.120)\end{array}$ & $\begin{array}{c}0.540^{* *} \\
(0.120)\end{array}$ \\
\hline$t=4 \times$ DOWN & $\begin{array}{c}0.150 \\
(0.135)\end{array}$ & $\begin{array}{c}0.155 \\
(0.134)\end{array}$ & $\begin{array}{c}0.073 \\
(0.128)\end{array}$ & $\begin{array}{c}0.081 \\
(0.130)\end{array}$ & $\begin{array}{c}0.450^{* *} \\
(0.119)\end{array}$ & $\begin{array}{c}0.450^{* *} \\
(0.119)\end{array}$ & $\begin{array}{c}0.088 \\
(0.108)\end{array}$ & $\begin{array}{c}0.089 \\
(0.108)\end{array}$ \\
\hline$t=2 \times \mathrm{UP}$ & $\begin{array}{c}0.088 \\
(0.114)\end{array}$ & $\begin{array}{c}0.093 \\
(0.115)\end{array}$ & $\begin{array}{r}-0.251^{*} \\
(0.124)\end{array}$ & $\begin{array}{c}-0.247^{*} \\
(0.125)\end{array}$ & $\begin{array}{c}-0.039 \\
(0.124)\end{array}$ & $\begin{array}{c}-0.038 \\
(0.124)\end{array}$ & $\begin{array}{c}-0.088 \\
(0.117)\end{array}$ & $\begin{array}{c}-0.085 \\
(0.117)\end{array}$ \\
\hline$t=1 \times \mathrm{UP}$ & $\begin{array}{c}0.163 \\
(0.104)\end{array}$ & $\begin{array}{c}0.159 \\
(0.104)\end{array}$ & $\begin{array}{c}0.025 \\
(0.114)\end{array}$ & $\begin{array}{c}0.022 \\
(0.115)\end{array}$ & $\begin{array}{r}-0.265^{*} \\
(0.133)\end{array}$ & $\begin{array}{r}-0.267^{*} \\
(0.133)\end{array}$ & $\begin{array}{r}-0.257^{*} \\
(0.114)\end{array}$ & $\begin{array}{r}-0.259^{*} \\
(0.114)\end{array}$ \\
\hline$t=3 \times \mathrm{UP}$ & $\begin{array}{c}0.098 \\
(0.116)\end{array}$ & $\begin{array}{c}0.101 \\
(0.116)\end{array}$ & $\begin{array}{c}-0.049 \\
(0.113)\end{array}$ & $\begin{array}{c}-0.048 \\
(0.113)\end{array}$ & $\begin{array}{c}-0.918^{* *} \\
(0.137)\end{array}$ & $\begin{array}{c}-0.917^{* *} \\
(0.138)\end{array}$ & $\begin{array}{c}-0.588^{* *} \\
(0.125)\end{array}$ & $\begin{array}{c}-0.588^{* *} \\
(0.125)\end{array}$ \\
\hline$t=4 \times \mathrm{UP}$ & $\begin{array}{c}0.079 \\
(0.103)\end{array}$ & $\begin{array}{c}0.076 \\
(0.102)\end{array}$ & $\begin{array}{c}-0.007 \\
(0.131)\end{array}$ & $\begin{array}{c}0.005 \\
(0.133)\end{array}$ & $\begin{array}{c}-0.188 \\
(0.127)\end{array}$ & $\begin{array}{c}-0.189 \\
(0.127)\end{array}$ & $\begin{array}{c}-0.202 \\
(0.125)\end{array}$ & $\begin{array}{c}-0.201 \\
(0.125)\end{array}$ \\
\hline Constant & $\begin{array}{c}4.276^{* *} \\
(0.115)\end{array}$ & $\begin{array}{c}2.717^{* *} \\
(0.577)\end{array}$ & $\begin{array}{c}4.902^{* *} \\
(0.129)\end{array}$ & $\begin{array}{c}4.470^{* *} \\
(0.644)\end{array}$ & $\begin{array}{c}4.357^{* *} \\
(0.103)\end{array}$ & $\begin{array}{c}4.080^{* *} \\
(0.692)\end{array}$ & $\begin{array}{c}4.736^{* *} \\
(0.106)\end{array}$ & $\begin{array}{c}4.032^{* *} \\
(0.567)\end{array}$ \\
\hline Controls & No & Yes & No & Yes & No & Yes & No & Yes \\
\hline Observations & 1,172 & 1,172 & 1,220 & 1,220 & 1,560 & 1,560 & 1,776 & 1,776 \\
\hline $\mathrm{R}^{2}$ & 0.179 & 0.223 & 0.113 & 0.157 & 0.174 & 0.179 & 0.093 & 0.102 \\
\hline Adjusted $\mathrm{R}^{2}$ & 0.171 & 0.213 & 0.105 & 0.146 & 0.168 & 0.171 & 0.088 & 0.094 \\
\hline
\end{tabular}


Table C8: Ordinary least squares regressions on PRICE FORECAST for each participant pool (financial professionals and students) and each presentation format (RETURNS or PRICES). $t$ indicates time period and UP and DOWN stand for the direction of the shock in the respective treatment. $t=2$ and the STRAIGHT path act as the reference categories. Controls include a participant's risk tolerance, CRT score, age, and gender. Clustered standard errors on the participant-level are in parentheses. ${ }^{*}$ and ${ }^{* *}$ indicate the $5 \%$ - and the $0.5 \%$-significance levels, respectively.

\begin{tabular}{|c|c|c|c|c|c|c|c|c|}
\hline & \multicolumn{8}{|c|}{ Dependent variable: PRICE FORECAST } \\
\hline & \multicolumn{4}{|c|}{ Financial Professionals } & \multicolumn{4}{|c|}{ Students } \\
\hline & \multicolumn{2}{|c|}{ PRICES } & \multicolumn{2}{|c|}{ RETURNS } & \multicolumn{2}{|c|}{ PRICES } & \multicolumn{2}{|c|}{ RETURNS } \\
\hline & (1) & (2) & (3) & (4) & (5) & (6) & (7) & (8) \\
\hline$t=1$ & $\begin{array}{c}-3.576^{* *} \\
(0.814)\end{array}$ & $\begin{array}{c}-3.576^{* *} \\
(0.815)\end{array}$ & $\begin{array}{c}-3.904^{* *} \\
(0.270)\end{array}$ & $\begin{array}{c}-3.904^{* *} \\
(0.271)\end{array}$ & $\begin{array}{c}-2.293 \\
(1.387)\end{array}$ & $\begin{array}{c}-2.293 \\
(1.389)\end{array}$ & $\begin{array}{c}-3.373^{* *} \\
(0.703)\end{array}$ & $\begin{array}{c}-3.373^{* *} \\
(0.704)\end{array}$ \\
\hline$t=3$ & $\begin{array}{c}0.151 \\
(0.487)\end{array}$ & $\begin{array}{c}0.151 \\
(0.488)\end{array}$ & $\begin{array}{c}-1.339^{* *} \\
(0.351)\end{array}$ & $\begin{array}{c}-1.339^{* *} \\
(0.352)\end{array}$ & $\begin{array}{c}1.901 \\
(1.275)\end{array}$ & $\begin{array}{c}1.901 \\
(1.277)\end{array}$ & $\begin{array}{c}-0.567 \\
(0.646)\end{array}$ & $\begin{array}{c}-0.567 \\
(0.647)\end{array}$ \\
\hline$t=4$ & $\begin{array}{c}-0.897 \\
(0.577)\end{array}$ & $\begin{array}{c}-0.897 \\
(0.579)\end{array}$ & $\begin{array}{c}-2.887^{* *} \\
(0.287)\end{array}$ & $\begin{array}{c}-2.887^{* *} \\
(0.288)\end{array}$ & $\begin{array}{c}-0.831 \\
(1.240)\end{array}$ & $\begin{array}{c}-0.831 \\
(1.242)\end{array}$ & $\begin{array}{c}-2.806^{* *} \\
(0.737)\end{array}$ & $\begin{array}{c}-2.806^{* *} \\
(0.738)\end{array}$ \\
\hline$t=2 \times$ DOWN & $\begin{array}{c}-0.444 \\
(1.312)\end{array}$ & $\begin{array}{c}-0.444 \\
(1.314)\end{array}$ & $\begin{array}{c}-1.999^{* *} \\
(0.217)\end{array}$ & $\begin{array}{c}-1.999^{* *} \\
(0.218)\end{array}$ & $\begin{array}{c}-0.241 \\
(1.521)\end{array}$ & $\begin{array}{c}-0.241 \\
(1.523)\end{array}$ & $\begin{array}{c}-1.361 \\
(0.812)\end{array}$ & $\begin{array}{c}-1.361 \\
(0.813)\end{array}$ \\
\hline$t=1 \times$ DOWN & $\begin{array}{c}2.455^{* *} \\
(0.730)\end{array}$ & $\begin{array}{c}2.455^{* *} \\
(0.732)\end{array}$ & $\begin{array}{c}3.442^{* *} \\
(0.269)\end{array}$ & $\begin{array}{c}3.442^{* *} \\
(0.270)\end{array}$ & $\begin{array}{c}2.210 \\
(1.437)\end{array}$ & $\begin{array}{c}2.210 \\
(1.440)\end{array}$ & $\begin{array}{c}3.524^{* *} \\
(0.889)\end{array}$ & $\begin{array}{c}3.524^{* *} \\
(0.890)\end{array}$ \\
\hline$t=3 \times$ DOWN & $\begin{array}{c}-14.235^{* *} \\
(1.530)\end{array}$ & $\begin{array}{c}-14.235^{* *} \\
(1.533)\end{array}$ & $\begin{array}{c}-16.892^{* *} \\
(0.505)\end{array}$ & $\begin{array}{c}-16.892^{* *} \\
(0.506)\end{array}$ & $\begin{array}{c}-15.321^{* *} \\
(1.391)\end{array}$ & $\begin{array}{c}-15.321^{* *} \\
(1.393)\end{array}$ & $\begin{array}{c}-21.874^{* *} \\
(0.909)\end{array}$ & $\begin{array}{r}-21.874^{* *} \\
(0.910)\end{array}$ \\
\hline$t=4 \times$ DOWN & $\begin{array}{c}-13.548^{* *} \\
(1.532)\end{array}$ & $\begin{array}{c}-13.548^{* *} \\
(1.535)\end{array}$ & $\begin{array}{c}-14.552^{* *} \\
(0.385)\end{array}$ & $\begin{array}{c}-14.552^{* *} \\
(0.386)\end{array}$ & $\begin{array}{c}-13.829^{* *} \\
(1.123)\end{array}$ & $\begin{array}{c}-13.829^{* *} \\
(1.125)\end{array}$ & $\begin{array}{c}-16.938^{* *} \\
(0.721)\end{array}$ & $\begin{array}{r}-16.938^{* *} \\
(0.722)\end{array}$ \\
\hline$t=2 \times \mathrm{UP}$ & $\begin{array}{c}0.234 \\
(0.502)\end{array}$ & $\begin{array}{c}0.234 \\
(0.503)\end{array}$ & $\begin{array}{c}-0.757^{* *} \\
(0.255)\end{array}$ & $\begin{array}{c}-0.757^{* *} \\
(0.256)\end{array}$ & $\begin{array}{c}-1.319 \\
(1.303)\end{array}$ & $\begin{array}{r}-1.319 \\
(1.305)\end{array}$ & $\begin{array}{c}-0.076 \\
(0.540)\end{array}$ & $\begin{array}{c}-0.076 \\
(0.541)\end{array}$ \\
\hline$t=1 \times \mathrm{UP}$ & $\begin{array}{c}3.031 \\
(2.154)\end{array}$ & $\begin{array}{c}3.031 \\
(2.159)\end{array}$ & $\begin{array}{c}1.935^{* *} \\
(0.283)\end{array}$ & $\begin{array}{c}1.935^{* *} \\
(0.283)\end{array}$ & $\begin{array}{c}0.203 \\
(1.358)\end{array}$ & $\begin{array}{c}0.203 \\
(1.360)\end{array}$ & $\begin{array}{c}1.031 \\
(0.706)\end{array}$ & $\begin{array}{c}1.031 \\
(0.707)\end{array}$ \\
\hline$t=3 \times \mathrm{UP}$ & $\begin{array}{l}15.969^{* *} \\
(1.243)\end{array}$ & $\begin{array}{l}15.969^{* *} \\
(1.246)\end{array}$ & $\begin{array}{l}16.796^{* *} \\
(0.431)\end{array}$ & $\begin{array}{l}16.796^{* *} \\
(0.432)\end{array}$ & $\begin{array}{l}12.259^{* *} \\
(1.571)\end{array}$ & $\begin{array}{l}12.259^{* *} \\
(1.574)\end{array}$ & $\begin{array}{l}18.987^{* *} \\
(0.830)\end{array}$ & $\begin{array}{l}18.987^{* *} \\
(0.831)\end{array}$ \\
\hline$t=4 \times \mathrm{UP}$ & $\begin{array}{l}14.681^{* *} \\
(0.681)\end{array}$ & $\begin{array}{l}14.681^{* *} \\
(0.682)\end{array}$ & $\begin{array}{l}16.774^{* *} \\
(0.319)\end{array}$ & $\begin{array}{l}16.774^{* *} \\
(0.320)\end{array}$ & $\begin{array}{l}11.825^{* *} \\
(1.286)\end{array}$ & $\begin{array}{l}11.825^{* *} \\
(1.289)\end{array}$ & $\begin{array}{l}16.746^{* *} \\
(0.721)\end{array}$ & $\begin{array}{l}16.746^{* *} \\
(0.722)\end{array}$ \\
\hline Constant & $\begin{array}{c}100.716^{* *} \\
(1.030)\end{array}$ & $\begin{array}{c}101.138^{* *} \\
(3.447)\end{array}$ & $\begin{array}{c}102.815^{* *} \\
(0.238)\end{array}$ & $\begin{array}{c}100.684^{* *} \\
(0.999)\end{array}$ & $\begin{array}{l}99.599^{* *} \\
(1.652)\end{array}$ & $\begin{array}{l}94.194^{* *} \\
(8.283)\end{array}$ & $\begin{array}{c}107.662^{* *} \\
(1.246)\end{array}$ & $\begin{array}{c}121.188^{* *} \\
(9.897)\end{array}$ \\
\hline Controls & No & Yes & No & Yes & No & Yes & No & Yes \\
\hline Observations & 1,188 & 1,188 & 1,236 & 1,236 & 1,584 & 1,584 & 1,800 & 1,800 \\
\hline $\mathrm{R}^{2}$ & 0.316 & 0.349 & 0.911 & 0.917 & 0.211 & 0.242 & 0.319 & 0.360 \\
\hline Adjusted $\mathrm{R}^{2}$ & 0.309 & 0.340 & 0.911 & 0.916 & 0.205 & 0.234 & 0.315 & 0.354 \\
\hline
\end{tabular}


Table C9: Ordinary least squares regressions on RETURN FORECAST for each participant pool (financial professionals and students) and each presentation format (RETURNS or PRICES). $t$ indicates time period and UP and DOWN stand for the direction of the shock in the respective treatment. $t=2$ and the STRAIGHT path act as the reference categories. Controls include a participant's risk tolerance, CRT score, age, and gender. Clustered standard errors on the participant-level are in parentheses. ${ }^{*}$ and ${ }^{* *}$ indicate the 5\%- and the $0.5 \%$-significance levels, respectively.

\begin{tabular}{|c|c|c|c|c|c|c|c|c|}
\hline & \multicolumn{8}{|c|}{ Dependent variable: RETURN FORECAST } \\
\hline & \multicolumn{4}{|c|}{ Financial Professionals } & \multicolumn{4}{|c|}{ Students } \\
\hline & \multicolumn{2}{|c|}{ PRICES } & \multicolumn{2}{|c|}{ RETURNS } & \multicolumn{2}{|c|}{ PRICES } & \multicolumn{2}{|c|}{ RETURNS } \\
\hline & (1) & (2) & (3) & (4) & (5) & (6) & (7) & (8) \\
\hline$t=1$ & $\begin{array}{c}0.192 \\
(0.841)\end{array}$ & $\begin{array}{c}0.192 \\
(0.842)\end{array}$ & $\begin{array}{c}-0.064 \\
(0.271)\end{array}$ & $\begin{array}{c}-0.064 \\
(0.272)\end{array}$ & $\begin{array}{c}1.469 \\
(1.385)\end{array}$ & $\begin{array}{c}1.469 \\
(1.387)\end{array}$ & $\begin{array}{c}0.668 \\
(0.717)\end{array}$ & $\begin{array}{c}0.668 \\
(0.718)\end{array}$ \\
\hline$t=3$ & $\begin{array}{c}1.474^{* *} \\
(0.491)\end{array}$ & $\begin{array}{c}1.474^{* *} \\
(0.492)\end{array}$ & $\begin{array}{c}0.105 \\
(0.331)\end{array}$ & $\begin{array}{c}0.105 \\
(0.332)\end{array}$ & $\begin{array}{c}3.278^{*} \\
(1.272)\end{array}$ & $\begin{array}{c}3.278^{*} \\
(1.274)\end{array}$ & $\begin{array}{c}0.872 \\
(0.623)\end{array}$ & $\begin{array}{c}0.872 \\
(0.624)\end{array}$ \\
\hline$t=4$ & $\begin{array}{c}2.112^{* *} \\
(0.561)\end{array}$ & $\begin{array}{c}2.112^{* *} \\
(0.562)\end{array}$ & $\begin{array}{c}0.252 \\
(0.253)\end{array}$ & $\begin{array}{c}0.252 \\
(0.254)\end{array}$ & $\begin{array}{c}2.229 \\
(1.236)\end{array}$ & $\begin{array}{c}2.229 \\
(1.238)\end{array}$ & $\begin{array}{c}0.395 \\
(0.697)\end{array}$ & $\begin{array}{c}0.395 \\
(0.698)\end{array}$ \\
\hline$t=2 \times$ DOWN & $\begin{array}{c}1.492 \\
(1.316)\end{array}$ & $\begin{array}{c}1.492 \\
(1.318)\end{array}$ & $\begin{array}{c}0.025 \\
(0.215)\end{array}$ & $\begin{array}{c}0.025 \\
(0.216)\end{array}$ & $\begin{array}{c}1.663 \\
(1.517)\end{array}$ & $\begin{array}{c}1.663 \\
(1.519)\end{array}$ & $\begin{array}{c}0.742 \\
(0.815)\end{array}$ & $\begin{array}{c}0.742 \\
(0.816)\end{array}$ \\
\hline$t=1 \times$ DOWN & $\begin{array}{c}-0.596 \\
(0.743)\end{array}$ & $\begin{array}{c}-0.596 \\
(0.745)\end{array}$ & $\begin{array}{c}0.062 \\
(0.178)\end{array}$ & $\begin{array}{c}0.062 \\
(0.178)\end{array}$ & $\begin{array}{c}-0.816 \\
(1.462)\end{array}$ & $\begin{array}{c}-0.816 \\
(1.465)\end{array}$ & $\begin{array}{c}0.039 \\
(0.845)\end{array}$ & $\begin{array}{c}0.039 \\
(0.846)\end{array}$ \\
\hline$t=3 \times$ DOWN & $\begin{array}{c}5.180^{* *} \\
(1.624)\end{array}$ & $\begin{array}{c}5.180^{* *} \\
(1.627)\end{array}$ & $\begin{array}{c}1.736^{* *} \\
(0.533)\end{array}$ & $\begin{array}{c}1.736^{* *} \\
(0.535)\end{array}$ & $\begin{array}{c}3.916^{*} \\
(1.432)\end{array}$ & $\begin{array}{c}3.916^{*} \\
(1.434)\end{array}$ & $\begin{array}{c}-2.937^{* *} \\
(0.968)\end{array}$ & $\begin{array}{c}-2.937^{* *} \\
(0.969)\end{array}$ \\
\hline$t=4 \times$ DOWN & $\begin{array}{c}2.536 \\
(1.651)\end{array}$ & $\begin{array}{c}2.536 \\
(1.655)\end{array}$ & $\begin{array}{c}0.945^{* *} \\
(0.269)\end{array}$ & $\begin{array}{c}0.945^{* *} \\
(0.270)\end{array}$ & $\begin{array}{c}1.910 \\
(1.207)\end{array}$ & $\begin{array}{c}1.910 \\
(1.209)\end{array}$ & $\begin{array}{c}-0.833 \\
(0.638)\end{array}$ & $\begin{array}{c}-0.833 \\
(0.639)\end{array}$ \\
\hline$t=2 \times \mathrm{UP}$ & $\begin{array}{c}0.702 \\
(0.501)\end{array}$ & $\begin{array}{c}0.702 \\
(0.502)\end{array}$ & $\begin{array}{c}-0.250 \\
(0.246)\end{array}$ & $\begin{array}{c}-0.250 \\
(0.247)\end{array}$ & $\begin{array}{c}-0.818 \\
(1.287)\end{array}$ & $\begin{array}{c}-0.818 \\
(1.289)\end{array}$ & $\begin{array}{c}0.464 \\
(0.534)\end{array}$ & $\begin{array}{c}0.464 \\
(0.534)\end{array}$ \\
\hline$t=1 \times \mathrm{UP}$ & $\begin{array}{c}1.081 \\
(2.214)\end{array}$ & $\begin{array}{c}1.081 \\
(2.219)\end{array}$ & $\begin{array}{c}-0.171 \\
(0.214)\end{array}$ & $\begin{array}{c}-0.171 \\
(0.215)\end{array}$ & $\begin{array}{c}-1.906 \\
(1.370)\end{array}$ & $\begin{array}{c}-1.906 \\
(1.372)\end{array}$ & $\begin{array}{c}-1.266 \\
(0.691)\end{array}$ & $\begin{array}{c}-1.266 \\
(0.692)\end{array}$ \\
\hline$t=3 \times \mathrm{UP}$ & $\begin{array}{c}-0.844 \\
(1.019)\end{array}$ & $\begin{array}{c}-0.844 \\
(1.021)\end{array}$ & $\begin{array}{c}-0.349 \\
(0.320)\end{array}$ & $\begin{array}{c}-0.349 \\
(0.320)\end{array}$ & $\begin{array}{c}-4.301^{* *} \\
(1.429)\end{array}$ & $\begin{array}{c}-4.301^{* *} \\
(1.431)\end{array}$ & $\begin{array}{c}0.736 \\
(0.743)\end{array}$ & $\begin{array}{c}0.736 \\
(0.744)\end{array}$ \\
\hline$t=4 \times \mathrm{UP}$ & $\begin{array}{r}-1.727^{*} \\
(0.624)\end{array}$ & $\begin{array}{r}-1.727^{*} \\
(0.625)\end{array}$ & $\begin{array}{c}-0.116 \\
(0.211)\end{array}$ & $\begin{array}{c}-0.116 \\
(0.211)\end{array}$ & $\begin{array}{c}-4.259^{* *} \\
(1.161)\end{array}$ & $\begin{array}{c}-4.259^{* *} \\
(1.163)\end{array}$ & $\begin{array}{c}-0.826 \\
(0.688)\end{array}$ & $\begin{array}{c}-0.826 \\
(0.689)\end{array}$ \\
\hline Constant & $\begin{array}{c}-0.334 \\
(1.020)\end{array}$ & $\begin{array}{c}0.342 \\
(3.527)\end{array}$ & $\begin{array}{c}1.743^{* *} \\
(0.235)\end{array}$ & $\begin{array}{c}0.076 \\
(1.007)\end{array}$ & $\begin{array}{c}-1.439 \\
(1.635)\end{array}$ & $\begin{array}{c}-6.485 \\
(8.385)\end{array}$ & $\begin{array}{c}6.540^{* *} \\
(1.233)\end{array}$ & $\begin{array}{c}20.125^{*} \\
(10.036)\end{array}$ \\
\hline Controls & No & Yes & No & Yes & No & Yes & No & Yes \\
\hline Observations & 1,188 & 1,188 & 1,236 & 1,236 & 1,584 & 1,584 & 1,800 & 1,800 \\
\hline $\mathrm{R}^{2}$ & 0.024 & 0.065 & 0.050 & 0.091 & 0.026 & 0.065 & 0.003 & 0.065 \\
\hline Adjusted $\mathrm{R}^{2}$ & 0.015 & 0.052 & 0.042 & 0.079 & 0.019 & 0.056 & -0.003 & 0.057 \\
\hline
\end{tabular}


Table C10: Ordinary least squares regressions on Optimistic minus Pessimistic Forecasts for each participant pool (financial professionals and students) and each presentation format (RETURNS or PRICES). $t$ indicates time period and UP and DOWN stand for the direction of the shock in the respective treatment. $t=2$ and the STRAIGHT path act as the reference categories. Controls include a participant's risk tolerance, CRT score, age, and gender. Clustered standard errors on the participantlevel are in parentheses. ${ }^{*}$ and ${ }^{* *}$ indicate the $5 \%$ - and the $0.5 \%$-significance levels, respectively.

\begin{tabular}{|c|c|c|c|c|c|c|c|c|}
\hline & \multicolumn{8}{|c|}{ Dependent variable: Optimistic minus Pessimistic Forecast } \\
\hline & \multicolumn{4}{|c|}{ Financial Professionals } & \multicolumn{4}{|c|}{ Students } \\
\hline & \multicolumn{2}{|c|}{ PRICES } & \multicolumn{2}{|c|}{ RETURNS } & \multicolumn{2}{|c|}{ PRICES } & \multicolumn{2}{|c|}{ RETURNS } \\
\hline & (1) & (2) & (3) & (4) & (5) & (6) & (7) & (8) \\
\hline$t=1$ & $\begin{array}{c}0.482 \\
(0.550)\end{array}$ & $\begin{array}{c}0.482 \\
(0.552)\end{array}$ & $\begin{array}{c}0.068 \\
(0.272)\end{array}$ & $\begin{array}{c}0.068 \\
(0.273)\end{array}$ & $\begin{array}{c}1.387 \\
(0.905)\end{array}$ & $\begin{array}{c}1.387 \\
(0.906)\end{array}$ & $\begin{array}{c}0.908 \\
(0.770)\end{array}$ & $\begin{array}{c}0.908 \\
(0.771)\end{array}$ \\
\hline$t=3$ & $\begin{array}{c}3.951^{* *} \\
(0.832)\end{array}$ & $\begin{array}{c}3.951^{* *} \\
(0.834)\end{array}$ & $\begin{array}{r}2.168^{*} \\
(0.794)\end{array}$ & $\begin{array}{c}2.168^{*} \\
(0.796)\end{array}$ & $\begin{array}{c}6.263^{* *} \\
(0.741)\end{array}$ & $\begin{array}{c}6.263^{* *} \\
(0.742)\end{array}$ & $\begin{array}{c}1.533^{*} \\
(0.647)\end{array}$ & $\begin{array}{c}1.533^{*} \\
(0.648)\end{array}$ \\
\hline$t=4$ & $\begin{array}{c}2.179^{*} \\
(0.844)\end{array}$ & $\begin{array}{c}2.179^{*} \\
(0.846)\end{array}$ & $\begin{array}{c}-0.319 \\
(0.474)\end{array}$ & $\begin{array}{c}-0.319 \\
(0.475)\end{array}$ & $\begin{array}{c}3.128^{* *} \\
(0.848)\end{array}$ & $\begin{array}{c}3.128^{* *} \\
(0.850)\end{array}$ & $\begin{array}{c}1.620 \\
(1.160)\end{array}$ & $\begin{array}{c}1.620 \\
(1.161)\end{array}$ \\
\hline$t=2 \times$ DOWN & $\begin{array}{r}-1.526^{*} \\
(0.710)\end{array}$ & $\begin{array}{r}-1.526^{*} \\
(0.712)\end{array}$ & $\begin{array}{c}-0.889 \\
(0.583)\end{array}$ & $\begin{array}{c}-0.889 \\
(0.584)\end{array}$ & $\begin{array}{c}-0.593 \\
(0.899)\end{array}$ & $\begin{array}{c}-0.593 \\
(0.901)\end{array}$ & $\begin{array}{c}1.308 \\
(0.867)\end{array}$ & $\begin{array}{c}1.308 \\
(0.868)\end{array}$ \\
\hline$t=1 \times$ DOWN & $\begin{array}{c}-1.767 \\
(0.963)\end{array}$ & $\begin{array}{c}-1.767 \\
(0.965)\end{array}$ & $\begin{array}{r}-1.222^{*} \\
(0.573)\end{array}$ & $\begin{array}{r}-1.222^{*} \\
(0.575)\end{array}$ & $\begin{array}{c}9.648 \\
(10.143)\end{array}$ & $\begin{array}{c}9.648 \\
(10.159)\end{array}$ & $\begin{array}{c}-0.051 \\
(1.050)\end{array}$ & $\begin{array}{c}-0.051 \\
(1.052)\end{array}$ \\
\hline$t=3 \times$ DOWN & $\begin{array}{c}4.360^{* *} \\
(0.980)\end{array}$ & $\begin{array}{c}4.360^{* *} \\
(0.982)\end{array}$ & $\begin{array}{c}4.673^{* *} \\
(1.117)\end{array}$ & $\begin{array}{c}4.673^{* *} \\
(1.119)\end{array}$ & $\begin{array}{c}5.959^{* *} \\
(1.283)\end{array}$ & $\begin{array}{c}5.959^{* *} \\
(1.285)\end{array}$ & $\begin{array}{c}4.849^{* *} \\
(0.918)\end{array}$ & $\begin{array}{c}4.849^{* *} \\
(0.919)\end{array}$ \\
\hline$t=4 \times$ DOWN & $\begin{array}{c}3.506^{* *} \\
(0.902)\end{array}$ & $\begin{array}{c}3.506^{* *} \\
(0.904)\end{array}$ & $\begin{array}{c}3.907^{* *} \\
(0.759)\end{array}$ & $\begin{array}{c}3.907^{* *} \\
(0.760)\end{array}$ & $\begin{array}{c}3.644^{* *} \\
(1.076)\end{array}$ & $\begin{array}{c}3.644^{* *} \\
(1.078)\end{array}$ & $\begin{array}{c}1.126 \\
(1.029)\end{array}$ & $\begin{array}{c}1.126 \\
(1.030)\end{array}$ \\
\hline$t=2 \times \mathrm{UP}$ & $\begin{array}{c}-1.068 \\
(0.728)\end{array}$ & $\begin{array}{c}-1.068 \\
(0.730)\end{array}$ & $\begin{array}{r}-1.243^{*} \\
(0.599)\end{array}$ & $\begin{array}{r}-1.243^{*} \\
(0.600)\end{array}$ & $\begin{array}{c}0.958 \\
(1.222)\end{array}$ & $\begin{array}{c}0.958 \\
(1.224)\end{array}$ & $\begin{array}{c}0.209 \\
(0.749)\end{array}$ & $\begin{array}{c}0.209 \\
(0.750)\end{array}$ \\
\hline$t=1 \times \mathrm{UP}$ & $\begin{array}{c}-0.865 \\
(0.878)\end{array}$ & $\begin{array}{c}-0.865 \\
(0.880)\end{array}$ & $\begin{array}{c}-0.872 \\
(0.571)\end{array}$ & $\begin{array}{c}-0.872 \\
(0.572)\end{array}$ & $\begin{array}{c}-0.489 \\
(1.255)\end{array}$ & $\begin{array}{c}-0.489 \\
(1.257)\end{array}$ & $\begin{array}{c}-0.886 \\
(0.899)\end{array}$ & $\begin{array}{r}-0.886 \\
(0.900)\end{array}$ \\
\hline$t=3 \times \mathrm{UP}$ & $\begin{array}{c}0.039 \\
(0.859)\end{array}$ & $\begin{array}{c}0.039 \\
(0.861)\end{array}$ & $\begin{array}{c}-0.094 \\
(1.048)\end{array}$ & $\begin{array}{c}-0.094 \\
(1.050)\end{array}$ & $\begin{array}{r}-1.268 \\
(0.988)\end{array}$ & $\begin{array}{c}-1.268 \\
(0.990)\end{array}$ & $\begin{array}{c}2.555^{* *} \\
(0.764)\end{array}$ & $\begin{array}{c}2.555^{* *} \\
(0.765)\end{array}$ \\
\hline$t=4 \times \mathrm{UP}$ & $\begin{array}{c}0.164 \\
(0.702)\end{array}$ & $\begin{array}{c}0.164 \\
(0.704)\end{array}$ & $\begin{array}{c}0.618 \\
(0.769)\end{array}$ & $\begin{array}{c}0.618 \\
(0.771)\end{array}$ & $\begin{array}{c}-0.108 \\
(0.905)\end{array}$ & $\begin{array}{c}-0.108 \\
(0.906)\end{array}$ & $\begin{array}{c}-0.960 \\
(1.142)\end{array}$ & $\begin{array}{c}-0.960 \\
(1.144)\end{array}$ \\
\hline Constant & $\begin{array}{l}13.215^{* *} \\
(1.589)\end{array}$ & $\begin{array}{l}10.574 \\
(8.349)\end{array}$ & $\begin{array}{l}11.347^{* *} \\
(0.920)\end{array}$ & $\begin{array}{c}-1.888 \\
(5.777)\end{array}$ & $\begin{array}{l}11.541^{* *} \\
(1.075)\end{array}$ & $\begin{array}{l}13.874 \\
(8.792)\end{array}$ & $\begin{array}{c}10.844^{* *} \\
(0.957)\end{array}$ & $\begin{array}{l}17.628^{*} \\
(8.163)\end{array}$ \\
\hline Controls & No & Yes & No & Yes & No & Yes & No & Yes \\
\hline Observations & 1,188 & 1,188 & 1,236 & 1,236 & 1,584 & 1,584 & 1,800 & 1,800 \\
\hline $\mathrm{R}^{2}$ & 0.036 & 0.079 & 0.051 & 0.098 & 0.011 & 0.014 & 0.016 & 0.048 \\
\hline Adjusted $\mathrm{R}^{2}$ & 0.027 & 0.066 & 0.043 & 0.086 & 0.004 & 0.004 & 0.010 & 0.039 \\
\hline
\end{tabular}


Table C11: Ordinary least squares regressions on INVESTMENT for each participant pool (financial professionals and students) and each presentation format (RETURNS Or PRICES). POST_SHOCK is a dummy variable taking the value 1 for periods after the volatility shock (i.e., $t=3$ and $t=4$ ), zero otherwise, and PRE_SHOCK stands for a dummy variable taking the value 1 for periods before the shock (i.e., $t=1$ and $t=2$ ), zero otherwise. The interaction terms (e.g., POST_SHOCK $\times$ UP) measure the combined effects of the shock phase (i.e., before or after the shock) and the respective treatment (i.e., UP or DOWN). Controls include a participant's risk tolerance, CRT score, age, and gender. Clustered standard errors on the participant-level are in parentheses. * and ${ }^{* *}$ indicate the $5 \%$ - and the $0.5 \%$ significance levels, respectively.

\begin{tabular}{|c|c|c|c|c|c|c|c|c|}
\hline & \multicolumn{8}{|c|}{ Dependent variable: INVESTMENT } \\
\hline & \multicolumn{4}{|c|}{ Financial Professionals } & \multicolumn{4}{|c|}{ Students } \\
\hline & \multicolumn{2}{|c|}{ PRICES } & \multicolumn{2}{|c|}{ RETURNS } & \multicolumn{2}{|c|}{ PRICES } & \multicolumn{2}{|c|}{ RETURNS } \\
\hline & (1) & (2) & (3) & (4) & (5) & (6) & (7) & (8) \\
\hline POST_SHOCK & $\begin{array}{c}0.630 \\
(1.393)\end{array}$ & $\begin{array}{c}0.630 \\
(1.395)\end{array}$ & $\begin{array}{c}1.015 \\
(1.412)\end{array}$ & $\begin{array}{c}1.015 \\
(1.415)\end{array}$ & $\begin{array}{c}0.988 \\
(1.286)\end{array}$ & $\begin{array}{c}0.988 \\
(1.287)\end{array}$ & $\begin{array}{c}0.542 \\
(1.323)\end{array}$ & $\begin{array}{c}0.542 \\
(1.325)\end{array}$ \\
\hline PRE_SHOCK $\times$ DOWN & $\begin{array}{c}-3.381 \\
(1.878)\end{array}$ & $\begin{array}{c}-3.381 \\
(1.881)\end{array}$ & $\begin{array}{c}2.061 \\
(1.341)\end{array}$ & $\begin{array}{c}2.061 \\
(1.343)\end{array}$ & $\begin{array}{c}2.844 \\
(1.455)\end{array}$ & $\begin{array}{c}2.844 \\
(1.457)\end{array}$ & $\begin{array}{c}0.351 \\
(1.449)\end{array}$ & $\begin{array}{c}0.351 \\
(1.451)\end{array}$ \\
\hline POST_SHOCK $\times$ DOWN & $\begin{array}{c}4.966^{* *} \\
(1.687)\end{array}$ & $\begin{array}{c}4.966^{* *} \\
(1.690)\end{array}$ & $\begin{array}{c}6.462^{* *} \\
(1.906)\end{array}$ & $\begin{array}{c}6.462^{* *} \\
(1.909)\end{array}$ & $\begin{array}{c}2.350 \\
(1.946)\end{array}$ & $\begin{array}{c}2.350 \\
(1.949)\end{array}$ & $\begin{array}{c}0.651 \\
(1.633)\end{array}$ & $\begin{array}{c}0.651 \\
(1.635)\end{array}$ \\
\hline PRE_SHOCK $\times$ UP & $\begin{array}{c}0.581 \\
(1.476)\end{array}$ & $\begin{array}{c}0.581 \\
(1.479)\end{array}$ & $\begin{array}{c}2.421 \\
(1.553)\end{array}$ & $\begin{array}{c}2.421 \\
(1.555)\end{array}$ & $\begin{array}{c}0.190 \\
(1.647)\end{array}$ & $\begin{array}{c}0.190 \\
(1.649)\end{array}$ & $\begin{array}{c}-1.945 \\
(1.458)\end{array}$ & $\begin{array}{r}-1.945 \\
(1.459)\end{array}$ \\
\hline POST_SHOCK $\times$ UP & $\begin{array}{c}-7.694^{* *} \\
(2.388)\end{array}$ & $\begin{array}{c}-7.694^{* *} \\
(2.392)\end{array}$ & $\begin{array}{r}-5.874^{*} \\
(2.243)\end{array}$ & $\begin{array}{c}-5.874^{*} \\
(2.247)\end{array}$ & $\begin{array}{r}-4.514^{*} \\
(2.026)\end{array}$ & $\begin{array}{r}-4.514^{*} \\
(2.028)\end{array}$ & $\begin{array}{r}-3.180^{*} \\
(1.590)\end{array}$ & $\begin{array}{r}-3.180^{*} \\
(1.592)\end{array}$ \\
\hline Constant & $\begin{array}{l}74.937^{* *} \\
(2.271)\end{array}$ & $\begin{array}{c}36.104^{*} \\
(15.213)\end{array}$ & $\begin{array}{l}78.140^{* *} \\
(2.274)\end{array}$ & $\begin{array}{c}58.334^{* *} \\
(16.907)\end{array}$ & $\begin{array}{l}55.451^{* *} \\
(2.115)\end{array}$ & $\begin{array}{c}13.916 \\
(13.977)\end{array}$ & $\begin{array}{l}59.065^{* *} \\
(2.088)\end{array}$ & $\begin{array}{c}41.026^{*} \\
(17.081)\end{array}$ \\
\hline Controls & No & Yes & No & Yes & No & Yes & No & Yes \\
\hline Observations & 1,485 & 1,485 & 1,545 & 1,545 & 1,980 & 1,980 & 2,250 & 2,250 \\
\hline $\mathrm{R}^{2}$ & 0.018 & 0.178 & 0.016 & 0.123 & 0.005 & 0.168 & 0.002 & 0.141 \\
\hline Adjusted $\mathrm{R}^{2}$ & 0.015 & 0.172 & 0.013 & 0.117 & 0.003 & 0.164 & -0.0003 & 0.137 \\
\hline
\end{tabular}


Table C12: Ordinary least squares regressions on RECOMMENDATION for each participant pool (financial professionals and students) and each presentation format (RETURNS or PRICES). POST_SHOCK is a dummy variable taking the value 1 for periods after the volatility shock (i.e., $t=3$ and $t=4$ ), zero otherwise, and PRE_SHOCK stands for a dummy variable taking the value 1 for periods before the shock (i.e., $t=1$ and $t=2$ ), zero otherwise. The interaction terms (e.g., POST_SHOCK $\times$ UP) measure the combined effects of the shock phase (i.e., before or after the shock) and the respective treatment (i.e., UP or DOWN). Controls include a participant's risk tolerance, CRT score, age, and gender. Clustered standard errors on the participant-level are in parentheses. ${ }^{*}$ and ${ }^{* *}$ indicate the $5 \%$ - and the 0.5\%-significance levels, respectively.

\begin{tabular}{|c|c|c|c|c|c|c|c|c|}
\hline & \multicolumn{8}{|c|}{ Dependent variable: RECOMMENDATION } \\
\hline & \multicolumn{4}{|c|}{ Financial Professionals } & \multicolumn{4}{|c|}{ Students } \\
\hline & \multicolumn{2}{|c|}{ PRICES } & \multicolumn{2}{|c|}{ RETURNS } & \multicolumn{2}{|c|}{ PRICES } & \multicolumn{2}{|c|}{ RETURNS } \\
\hline & (1) & (2) & (3) & (4) & (5) & (6) & (7) & (8) \\
\hline POST_SHOCK & $\begin{array}{c}-0.106 \\
(0.062)\end{array}$ & $\begin{array}{c}-0.106 \\
(0.062)\end{array}$ & $\begin{array}{c}-0.204^{* *} \\
(0.070)\end{array}$ & $\begin{array}{c}-0.204^{* *} \\
(0.070)\end{array}$ & $\begin{array}{r}-0.144^{*} \\
(0.060)\end{array}$ & $\begin{array}{r}-0.144^{*} \\
(0.060)\end{array}$ & $\begin{array}{c}-0.240^{* *} \\
(0.064)\end{array}$ & $\begin{array}{c}-0.240^{* *} \\
(0.064)\end{array}$ \\
\hline PRE_SHOCK $\times$ DOWN & $\begin{array}{c}-0.020 \\
(0.052)\end{array}$ & $\begin{array}{c}-0.020 \\
(0.052)\end{array}$ & $\begin{array}{c}0.029 \\
(0.045)\end{array}$ & $\begin{array}{c}0.029 \\
(0.045)\end{array}$ & $\begin{array}{c}-0.008 \\
(0.059)\end{array}$ & $\begin{array}{c}-0.008 \\
(0.059)\end{array}$ & $\begin{array}{c}0.030 \\
(0.053)\end{array}$ & $\begin{array}{c}0.030 \\
(0.053)\end{array}$ \\
\hline POST_SHOCK $\times$ DOWN & $\begin{array}{c}0.369^{* *} \\
(0.076)\end{array}$ & $\begin{array}{c}0.369^{* *} \\
(0.076)\end{array}$ & $\begin{array}{c}0.306^{* *} \\
(0.084)\end{array}$ & $\begin{array}{c}0.306^{* *} \\
(0.084)\end{array}$ & $\begin{array}{c}0.216^{* *} \\
(0.072)\end{array}$ & $\begin{array}{c}0.216^{* *} \\
(0.072)\end{array}$ & $\begin{array}{c}0.067 \\
(0.067)\end{array}$ & $\begin{array}{c}0.067 \\
(0.067)\end{array}$ \\
\hline PRE_SHOCK $\times$ UP & $\begin{array}{r}-0.035 \\
(0.048)\end{array}$ & $\begin{array}{c}-0.035 \\
(0.048)\end{array}$ & $\begin{array}{c}-0.019 \\
(0.051)\end{array}$ & $\begin{array}{c}-0.019 \\
(0.051)\end{array}$ & $\begin{array}{c}-0.095 \\
(0.059)\end{array}$ & $\begin{array}{c}-0.095 \\
(0.059)\end{array}$ & $\begin{array}{c}0.027 \\
(0.056)\end{array}$ & $\begin{array}{c}0.027 \\
(0.056)\end{array}$ \\
\hline POST_SHOCK $\times$ UP & $\begin{array}{r}-0.157^{*} \\
(0.073)\end{array}$ & $\begin{array}{r}-0.157^{*} \\
(0.073)\end{array}$ & $\begin{array}{c}0.019 \\
(0.092)\end{array}$ & $\begin{array}{c}0.019 \\
(0.092)\end{array}$ & $\begin{array}{r}-0.205^{*} \\
(0.074)\end{array}$ & $\begin{array}{r}-0.205^{*} \\
(0.075)\end{array}$ & $\begin{array}{c}0.260^{* *} \\
(0.075)\end{array}$ & $\begin{array}{c}0.260^{* *} \\
(0.075)\end{array}$ \\
\hline Constant & $\begin{array}{l}3.222^{* *} \\
(0.052)\end{array}$ & $\begin{array}{c}3.106^{* *} \\
(0.262)\end{array}$ & $\begin{array}{l}3.204^{* *} \\
(0.051)\end{array}$ & $\begin{array}{c}3.063^{\text {** }} \\
(0.279)\end{array}$ & $\begin{array}{c}3.008^{* *} \\
(0.045)\end{array}$ & $\begin{array}{c}2.761^{* *} \\
(0.167)\end{array}$ & $\begin{array}{c}2.797^{* *} \\
(0.050)\end{array}$ & $\begin{array}{c}2.551^{* *} \\
(0.308)\end{array}$ \\
\hline Controls & No & Yes & No & Yes & No & Yes & No & Yes \\
\hline Observations & 1,188 & 1,188 & 1,236 & 1,236 & 1,584 & 1,584 & 1,800 & 1,800 \\
\hline $\mathrm{R}^{2}$ & 0.050 & 0.070 & 0.020 & 0.050 & 0.028 & 0.037 & 0.015 & 0.031 \\
\hline Adjusted $\mathrm{R}^{2}$ & 0.046 & 0.062 & 0.016 & 0.042 & 0.025 & 0.031 & 0.012 & 0.026 \\
\hline
\end{tabular}


Table C13: Ordinary least squares regressions on SATISFACTION for each participant pool (financial professionals and students) and each presentation format (RETURNS or PRICES). POST_SHOCK is a dummy variable taking the value 1 for periods after the volatility shock (i.e., $t=3$ and $t=4$ ), zero otherwise, and PRE_SHOCK stands for a dummy variable taking the value 1 for periods before the shock (i.e., $t=1$ and $t=2$ ), zero otherwise. The interaction terms (e.g., POST_SHOcK $\times$ UP) measure the combined effects of the shock phase (i.e., before or after the shock) and the respective treatment (i.e., UP or DOWN). Controls include a participant's risk tolerance, CRT score, age, and gender. Clustered standard errors on the participant-level are in parentheses. * and ${ }^{* *}$ indicate the $5 \%$ - and the $0.5 \%$ significance levels, respectively.

\begin{tabular}{|c|c|c|c|c|c|c|c|c|}
\hline & \multicolumn{8}{|c|}{ Dependent variable: SATISFACTION } \\
\hline & \multicolumn{4}{|c|}{ Financial Professionals } & \multicolumn{4}{|c|}{ Students } \\
\hline & \multicolumn{2}{|c|}{ PRICES } & \multicolumn{2}{|c|}{ RETURNS } & \multicolumn{2}{|c|}{ PRICES } & \multicolumn{2}{|c|}{ RETURNS } \\
\hline & (1) & (2) & (3) & (4) & (5) & (6) & (7) & (8) \\
\hline POST_SHOCK & $\begin{array}{c}-0.490^{* *} \\
(0.075)\end{array}$ & $\begin{array}{c}-0.490^{* *} \\
(0.075)\end{array}$ & $\begin{array}{c}-0.896^{* *} \\
(0.117)\end{array}$ & $\begin{array}{c}-0.899^{* *} \\
(0.117)\end{array}$ & $\begin{array}{c}-0.738^{* *} \\
(0.096)\end{array}$ & $\begin{array}{c}-0.738^{* *} \\
(0.096)\end{array}$ & $\begin{array}{c}-0.929^{* *} \\
(0.080)\end{array}$ & $\begin{array}{c}-0.929^{* *} \\
(0.080)\end{array}$ \\
\hline PRE_SHOCK $\times$ DOWN & $\begin{array}{c}-0.061 \\
(0.069)\end{array}$ & $\begin{array}{c}-0.061 \\
(0.069)\end{array}$ & $\begin{array}{c}-0.147 \\
(0.080)\end{array}$ & $\begin{array}{c}-0.147 \\
(0.080)\end{array}$ & $\begin{array}{r}-0.161^{*} \\
(0.082)\end{array}$ & $\begin{array}{c}-0.161 \\
(0.082)\end{array}$ & $\begin{array}{c}-0.264^{* *} \\
(0.085)\end{array}$ & $\begin{array}{c}-0.264^{* *} \\
(0.085)\end{array}$ \\
\hline POST_SHOCK $\times$ DOWN & $\begin{array}{c}-0.672^{* *} \\
(0.094)\end{array}$ & $\begin{array}{c}-0.673^{* *} \\
(0.094)\end{array}$ & $\begin{array}{r}-0.246^{*} \\
(0.112)\end{array}$ & $\begin{array}{r}-0.245^{*} \\
(0.113)\end{array}$ & $\begin{array}{c}-0.587^{* *} \\
(0.098)\end{array}$ & $\begin{array}{c}-0.587^{* *} \\
(0.098)\end{array}$ & $\begin{array}{c}-0.077 \\
(0.083)\end{array}$ & $\begin{array}{r}-0.077 \\
(0.083)\end{array}$ \\
\hline PRE_SHOCK $\times$ UP & $\begin{array}{c}0.086 \\
(0.061)\end{array}$ & $\begin{array}{c}0.086 \\
(0.061)\end{array}$ & $\begin{array}{c}-0.098 \\
(0.086)\end{array}$ & $\begin{array}{c}-0.099 \\
(0.086)\end{array}$ & $\begin{array}{c}-0.037 \\
(0.091)\end{array}$ & $\begin{array}{r}-0.037 \\
(0.091)\end{array}$ & $\begin{array}{c}-0.043 \\
(0.064)\end{array}$ & $\begin{array}{r}-0.044 \\
(0.065)\end{array}$ \\
\hline POST_SHOCK $\times$ UP & $\begin{array}{l}1.389^{* *} \\
(0.117)\end{array}$ & $\begin{array}{l}1.390^{\text {*** }} \\
(0.117)\end{array}$ & $\begin{array}{c}1.447^{* *} \\
(0.129)\end{array}$ & $\begin{array}{c}1.450^{* *} \\
(0.129)\end{array}$ & $\begin{array}{c}1.629^{* *} \\
(0.130)\end{array}$ & $\begin{array}{l}1.629^{* *} \\
(0.130)\end{array}$ & $\begin{array}{l}1.533^{* *} \\
(0.100)\end{array}$ & $\begin{array}{c}1.533^{* *} \\
(0.100)\end{array}$ \\
\hline Constant & $\begin{array}{c}0.076 \\
(0.082)\end{array}$ & $\begin{array}{r}-0.660 \\
(0.521)\end{array}$ & $\begin{array}{c}0.093 \\
(0.101)\end{array}$ & $\begin{array}{c}0.628 \\
(0.523)\end{array}$ & $\begin{array}{c}-0.274^{* *} \\
(0.056)\end{array}$ & $\begin{array}{r}-0.911^{*} \\
(0.371)\end{array}$ & $\begin{array}{c}-0.281^{* *} \\
(0.070)\end{array}$ & $\begin{array}{r}-0.501 \\
(0.476)\end{array}$ \\
\hline Controls & No & Yes & No & Yes & No & Yes & No & Yes \\
\hline Observations & 1,186 & 1,186 & 1,227 & 1,227 & 1,580 & 1,580 & 1,794 & 1,794 \\
\hline $\mathrm{R}^{2}$ & 0.164 & 0.173 & 0.103 & 0.115 & 0.161 & 0.167 & 0.106 & 0.107 \\
\hline Adjusted $\mathrm{R}^{2}$ & 0.160 & 0.165 & 0.099 & 0.108 & 0.159 & 0.161 & 0.103 & 0.102 \\
\hline
\end{tabular}


Table C14: Ordinary least squares regressions on RISK PERCEPTION for each participant pool (financial professionals and students) and each presentation format (RETURNS or PRICES). POST_SHOCK is a dummy variable taking the value 1 for periods after the volatility shock (i.e., $t=3$ and $t=4$ ), zero otherwise, and PRE_SHOCK stands for a dummy variable taking the value 1 for periods before the shock (i.e., $t=1$ and $t=2$ ), zero otherwise. The interaction terms (e.g., POST_SHOcK $\times$ UP) measure the combined effects of the shock phase (i.e., before or after the shock) and the respective treatment (i.e., UP or DOWN). Controls include a participant's risk tolerance, CRT score, age, and gender. Clustered standard errors on the participant-level are in parentheses. * and ${ }^{* *}$ indicate the $5 \%$ - and the $0.5 \%$ significance levels, respectively.

\begin{tabular}{|c|c|c|c|c|c|c|c|c|}
\hline & \multicolumn{8}{|c|}{ Dependent variable: RISK PERCEPTION } \\
\hline & \multicolumn{4}{|c|}{ Financial Professionals } & \multicolumn{4}{|c|}{ Students } \\
\hline & \multicolumn{2}{|c|}{ PRICES } & \multicolumn{2}{|c|}{ RETURNS } & \multicolumn{2}{|c|}{ PRICES } & \multicolumn{2}{|c|}{ RETURNS } \\
\hline & (1) & (2) & (3) & (4) & (5) & (6) & (7) & (8) \\
\hline POST_SHOCK & $\begin{array}{c}0.870^{* *} \\
(0.085)\end{array}$ & $\begin{array}{c}0.868^{* *} \\
(0.085)\end{array}$ & $\begin{array}{c}0.521^{* *} \\
(0.100)\end{array}$ & $\begin{array}{l}0.518^{* *} \\
(0.101)\end{array}$ & $\begin{array}{c}0.683^{* *} \\
(0.093)\end{array}$ & $\begin{array}{c}0.683^{* *} \\
(0.093)\end{array}$ & $\begin{array}{c}0.183^{*} \\
(0.088)\end{array}$ & $\begin{array}{c}0.183^{*} \\
(0.088)\end{array}$ \\
\hline PRE_SHOCK $\times$ DOWN & $\begin{array}{c}-0.067 \\
(0.095)\end{array}$ & $\begin{array}{c}-0.064 \\
(0.096)\end{array}$ & $\begin{array}{r}-0.158 \\
(0.113)\end{array}$ & $\begin{array}{c}-0.158 \\
(0.113)\end{array}$ & $\begin{array}{c}-0.431^{* *} \\
(0.114)\end{array}$ & $\begin{array}{c}-0.432^{* *} \\
(0.114)\end{array}$ & $\begin{array}{r}-0.184^{*} \\
(0.083)\end{array}$ & $\begin{array}{r}-0.183^{*} \\
(0.083)\end{array}$ \\
\hline POST_SHOCK $\times$ DOWN & $\begin{array}{c}0.201 \\
(0.112)\end{array}$ & $\begin{array}{c}0.204 \\
(0.110)\end{array}$ & $\begin{array}{c}0.088 \\
(0.099)\end{array}$ & $\begin{array}{c}0.094 \\
(0.099)\end{array}$ & $\begin{array}{c}0.311^{* *} \\
(0.098)\end{array}$ & $\begin{array}{c}0.310^{* *} \\
(0.098)\end{array}$ & $\begin{array}{c}0.310^{* *} \\
(0.090)\end{array}$ & $\begin{array}{c}0.310^{* *} \\
(0.090)\end{array}$ \\
\hline PRE_SHOCK $\times$ UP & $\begin{array}{c}0.126 \\
(0.092)\end{array}$ & $\begin{array}{c}0.126 \\
(0.092)\end{array}$ & $\begin{array}{c}-0.114 \\
(0.097)\end{array}$ & $\begin{array}{c}-0.113 \\
(0.098)\end{array}$ & $\begin{array}{c}-0.153 \\
(0.110)\end{array}$ & $\begin{array}{c}-0.154 \\
(0.110)\end{array}$ & $\begin{array}{r}-0.172 \\
(0.088)\end{array}$ & $\begin{array}{c}-0.171 \\
(0.089)\end{array}$ \\
\hline POST_SHOCK $\times$ UP & $\begin{array}{c}0.085 \\
(0.093)\end{array}$ & $\begin{array}{c}0.085 \\
(0.092)\end{array}$ & $\begin{array}{c}-0.033 \\
(0.103)\end{array}$ & $\begin{array}{c}-0.026 \\
(0.104)\end{array}$ & $\begin{array}{c}-0.551^{* *} \\
(0.111)\end{array}$ & $\begin{array}{c}-0.551^{* *} \\
(0.111)\end{array}$ & $\begin{array}{c}-0.398^{* *} \\
(0.099)\end{array}$ & $\begin{array}{c}-0.396^{* *} \\
(0.099)\end{array}$ \\
\hline Constant & $\begin{array}{l}4.250^{* *} \\
(0.109)\end{array}$ & $\begin{array}{c}2.676^{* *} \\
(0.569)\end{array}$ & $\begin{array}{c}4.818^{* *} \\
(0.120)\end{array}$ & $\begin{array}{c}4.387^{* *} \\
(0.636)\end{array}$ & $\begin{array}{c}4.465^{\text {** }} \\
(0.091)\end{array}$ & $\begin{array}{c}4.188^{* *} \\
(0.683)\end{array}$ & $\begin{array}{c}4.895^{* *} \\
(0.089)\end{array}$ & $\begin{array}{c}4.199^{* *} \\
(0.563)\end{array}$ \\
\hline Controls & No & Yes & No & Yes & No & Yes & No & Yes \\
\hline Observations & 1,172 & 1,172 & 1,220 & 1,220 & 1,560 & 1,560 & 1,776 & 1,776 \\
\hline $\mathrm{R}^{2}$ & 0.136 & 0.181 & 0.053 & 0.096 & 0.118 & 0.123 & 0.034 & 0.043 \\
\hline Adjusted $\mathrm{R}^{2}$ & 0.132 & 0.174 & 0.049 & 0.089 & 0.115 & 0.118 & 0.031 & 0.037 \\
\hline
\end{tabular}


Table C15: Ordinary least squares regressions on PRICE FORECAST for each participant pool (financial professionals and students) and each presentation format (RETURNS or PRICES). POST_SHOCK is a dummy variable taking the value 1 for periods after the volatility shock (i.e., $t=3$ and $t=4$ ), zero otherwise, and PRE_SHOCK stands for a dummy variable taking the value 1 for periods before the shock (i.e., $t=1$ and $t=2$ ), zero otherwise. The interaction terms (e.g., POST_SHOCK $\times$ UP) measure the combined effects of the shock phase (i.e., before or after the shock) and the respective treatment (i.e., UP or DOWN). Controls include a participant's risk tolerance, CRT score, age, and gender. Clustered standard errors on the participant-level are in parentheses. * and ${ }^{* *}$ indicate the $5 \%$ - and the $0.5 \%$ significance levels, respectively.

\begin{tabular}{|c|c|c|c|c|c|c|c|c|}
\hline & \multicolumn{8}{|c|}{ Dependent variable: PRICE FORECAST } \\
\hline & \multicolumn{4}{|c|}{ Financial Professionals } & \multicolumn{4}{|c|}{ Students } \\
\hline & \multicolumn{2}{|c|}{ PRICES } & \multicolumn{2}{|c|}{ RETURNS } & \multicolumn{2}{|c|}{ PRICES } & \multicolumn{2}{|c|}{ RETURNS } \\
\hline & (1) & (2) & (3) & (4) & (5) & (6) & (7) & (8) \\
\hline POST_SHOCK & $\begin{array}{c}1.415 \\
(0.722)\end{array}$ & $\begin{array}{c}1.415 \\
(0.724)\end{array}$ & $\begin{array}{c}-0.161 \\
(0.236)\end{array}$ & $\begin{array}{c}-0.161 \\
(0.237)\end{array}$ & $\begin{array}{c}1.681^{*} \\
(0.740)\end{array}$ & $\begin{array}{c}1.681^{*} \\
(0.741)\end{array}$ & $\begin{array}{c}-0.0003 \\
(0.454)\end{array}$ & $\begin{array}{c}-0.0003 \\
(0.455)\end{array}$ \\
\hline PRE_SHOCK $\times$ DOWN & $\begin{array}{c}1.006 \\
(0.872)\end{array}$ & $\begin{array}{c}1.006 \\
(0.874)\end{array}$ & $\begin{array}{l}0.721^{* *} \\
(0.165)\end{array}$ & $\begin{array}{l}0.721^{* *} \\
(0.166)\end{array}$ & $\begin{array}{c}0.984 \\
(1.138)\end{array}$ & $\begin{array}{c}0.984 \\
(1.140)\end{array}$ & $\begin{array}{c}1.081 \\
(0.677)\end{array}$ & $\begin{array}{c}1.081 \\
(0.678)\end{array}$ \\
\hline POST_SHOCK $\times$ DOWN & $\begin{array}{c}-13.892^{* *} \\
(1.457)\end{array}$ & $\begin{array}{c}-13.892^{* *} \\
(1.460)\end{array}$ & $\begin{array}{c}-15.722^{* *} \\
(0.388)\end{array}$ & $\begin{array}{c}-15.722^{* *} \\
(0.389)\end{array}$ & $\begin{array}{c}-14.575^{* *} \\
(1.037)\end{array}$ & $\begin{array}{c}-14.575^{* *} \\
(1.039)\end{array}$ & $\begin{array}{c}-19.406^{* *} \\
(0.619)\end{array}$ & $\begin{array}{c}-19.406^{* *} \\
(0.620)\end{array}$ \\
\hline PRE_SHOCK $\times$ UP & $\begin{array}{c}1.632 \\
(1.202)\end{array}$ & $\begin{array}{c}1.632 \\
(1.204)\end{array}$ & $\begin{array}{l}0.589^{* *} \\
(0.163)\end{array}$ & $\begin{array}{l}0.589^{* *} \\
(0.164)\end{array}$ & $\begin{array}{c}-0.558 \\
(0.971)\end{array}$ & $\begin{array}{c}-0.558 \\
(0.972)\end{array}$ & $\begin{array}{c}0.478 \\
(0.472)\end{array}$ & $\begin{array}{c}0.478 \\
(0.473)\end{array}$ \\
\hline POST_SHOCK $\times$ UP & $\begin{array}{l}15.325^{* *} \\
(0.835)\end{array}$ & $\begin{array}{l}15.325^{* *} \\
(0.837)\end{array}$ & $\begin{array}{l}16.785^{* *} \\
(0.338)\end{array}$ & $\begin{array}{l}16.785^{* *} \\
(0.338)\end{array}$ & $\begin{array}{l}12.042^{* *} \\
(1.114)\end{array}$ & $\begin{array}{l}12.042^{* *} \\
(1.115)\end{array}$ & $\begin{array}{l}17.867^{* *} \\
(0.583)\end{array}$ & $\begin{array}{l}17.867^{* *} \\
(0.584)\end{array}$ \\
\hline Constant & $\begin{array}{l}98.928^{* *} \\
(1.135)\end{array}$ & $\begin{array}{l}99.350^{* *} \\
(3.420)\end{array}$ & $\begin{array}{c}100.863^{* *} \\
(0.167)\end{array}$ & $\begin{array}{l}98.732^{* *} \\
(0.990)\end{array}$ & $\begin{array}{l}98.453^{* *} \\
(1.305)\end{array}$ & $\begin{array}{l}93.048^{* *} \\
(8.098)\end{array}$ & $\begin{array}{c}105.975^{* *} \\
(1.237)\end{array}$ & $\begin{array}{c}119.501^{* *} \\
(9.964)\end{array}$ \\
\hline Controls & No & Yes & No & Yes & No & Yes & No & Yes \\
\hline Observations & 1,188 & 1,188 & 1,236 & 1,236 & 1,584 & 1,584 & 1,800 & 1,800 \\
\hline $\mathrm{R}^{2}$ & 0.312 & 0.345 & 0.901 & 0.906 & 0.207 & 0.238 & 0.314 & 0.354 \\
\hline Adjusted $\mathrm{R}^{2}$ & 0.309 & 0.340 & 0.901 & 0.905 & 0.205 & 0.234 & 0.312 & 0.350 \\
\hline
\end{tabular}


Table C16: Ordinary least squares regressions on RETURN FORECAST for each participant pool (financial professionals and students) and each presentation format (RETURNS or PRICES). POST_SHOCK is a dummy variable taking the value 1 for periods after the volatility shock (i.e., $t=3$ and $t=4$ ), zero otherwise, and PRE_SHOCK stands for a dummy variable taking the value 1 for periods before the shock (i.e., $t=1$ and $t=2$ ), zero otherwise. The interaction terms (e.g., POST_SHOCK $\times$ UP) measure the combined effects of the shock phase (i.e., before or after the shock) and the respective treatment (i.e., UP or DOWN). Controls include a participant's risk tolerance, CRT score, age, and gender. Clustered standard errors on the participant-level are in parentheses. * and ${ }^{* *}$ indicate the $5 \%$ - and the $0.5 \%$-significance levels, respectively.

\begin{tabular}{|c|c|c|c|c|c|c|c|c|}
\hline & \multicolumn{8}{|c|}{ Dependent variable: RETURN FORECAST } \\
\hline & \multicolumn{4}{|c|}{ Financial Professionals } & \multicolumn{4}{|c|}{ Students } \\
\hline & \multicolumn{2}{|c|}{ PRICES } & \multicolumn{2}{|c|}{ RETURNS } & \multicolumn{2}{|c|}{ PRICES } & \multicolumn{2}{|c|}{ RETURNS } \\
\hline & (1) & (2) & (3) & (4) & (5) & (6) & (7) & (8) \\
\hline POST_SHOCK & $\begin{array}{c}1.697^{*} \\
(0.728)\end{array}$ & $\begin{array}{c}1.697^{*} \\
(0.729)\end{array}$ & $\begin{array}{c}0.211 \\
(0.186)\end{array}$ & $\begin{array}{c}0.211 \\
(0.186)\end{array}$ & $\begin{array}{c}2.019^{*} \\
(0.746)\end{array}$ & $\begin{array}{c}2.019^{*} \\
(0.747)\end{array}$ & $\begin{array}{c}0.300 \\
(0.437)\end{array}$ & $\begin{array}{c}0.300 \\
(0.437)\end{array}$ \\
\hline PRE_SHOCK $\times$ DOWN & $\begin{array}{c}0.448 \\
(0.880)\end{array}$ & $\begin{array}{c}0.448 \\
(0.881)\end{array}$ & $\begin{array}{c}0.044 \\
(0.141)\end{array}$ & $\begin{array}{c}0.044 \\
(0.141)\end{array}$ & $\begin{array}{c}0.423 \\
(1.140)\end{array}$ & $\begin{array}{c}0.423 \\
(1.142)\end{array}$ & $\begin{array}{c}0.390 \\
(0.672)\end{array}$ & $\begin{array}{c}0.390 \\
(0.673)\end{array}$ \\
\hline POST_SHOCK $\times$ DOWN & $\begin{array}{c}3.858^{*} \\
(1.547)\end{array}$ & $\begin{array}{c}3.858^{*} \\
(1.550)\end{array}$ & $\begin{array}{c}1.341^{* *} \\
(0.330)\end{array}$ & $\begin{array}{c}1.341^{* *} \\
(0.331)\end{array}$ & $\begin{array}{r}2.913^{*} \\
(1.067)\end{array}$ & $\begin{array}{c}2.913^{*} \\
(1.069)\end{array}$ & $\begin{array}{c}-1.885^{* *} \\
(0.575)\end{array}$ & $\begin{array}{c}-1.885^{* *} \\
(0.576)\end{array}$ \\
\hline PRE_SHOCK $\times$ UP & $\begin{array}{c}0.891 \\
(1.228)\end{array}$ & $\begin{array}{c}0.891 \\
(1.231)\end{array}$ & $\begin{array}{c}-0.211 \\
(0.150)\end{array}$ & $\begin{array}{c}-0.211 \\
(0.151)\end{array}$ & $\begin{array}{c}-1.362 \\
(0.980)\end{array}$ & $\begin{array}{c}-1.362 \\
(0.981)\end{array}$ & $\begin{array}{c}-0.401 \\
(0.470)\end{array}$ & $\begin{array}{c}-0.401 \\
(0.470)\end{array}$ \\
\hline POST_SHOCK $\times$ UP & $\begin{array}{c}-1.286 \\
(0.690)\end{array}$ & $\begin{array}{c}-1.286 \\
(0.691)\end{array}$ & $\begin{array}{c}-0.232 \\
(0.221)\end{array}$ & $\begin{array}{c}-0.232 \\
(0.222)\end{array}$ & $\begin{array}{c}-4.280^{* *} \\
(0.996)\end{array}$ & $\begin{array}{c}-4.280^{* *} \\
(0.997)\end{array}$ & $\begin{array}{c}-0.045 \\
(0.515)\end{array}$ & $\begin{array}{c}-0.045 \\
(0.516)\end{array}$ \\
\hline Constant & $\begin{array}{c}-0.237 \\
(1.149)\end{array}$ & $\begin{array}{c}0.439 \\
(3.492)\end{array}$ & $\begin{array}{l}1.711^{* *} \\
(0.168)\end{array}$ & $\begin{array}{c}0.044 \\
(0.995)\end{array}$ & $\begin{array}{c}-0.704 \\
(1.313)\end{array}$ & $\begin{array}{c}-5.751 \\
(8.203)\end{array}$ & $\begin{array}{c}6.874^{* *} \\
(1.249)\end{array}$ & $\begin{array}{c}20.459^{*} \\
(10.113)\end{array}$ \\
\hline Controls & No & Yes & No & Yes & No & Yes & No & Yes \\
\hline Observations & 1,188 & 1,188 & 1,236 & 1,236 & 1,584 & 1,584 & 1,800 & 1,800 \\
\hline $\mathrm{R}^{2}$ & 0.022 & 0.063 & 0.047 & 0.087 & 0.024 & 0.063 & 0.002 & 0.064 \\
\hline Adjusted $\mathrm{R}^{2}$ & 0.018 & 0.055 & 0.043 & 0.080 & 0.020 & 0.057 & -0.001 & 0.059 \\
\hline
\end{tabular}


Table C17: Ordinary least squares regressions on Optimistic minus Pessimistic Forecasts for each participant pool (financial professionals and students) and each presentation format (RETURNS or PRICES). POST_SHOCK is a dummy variable taking the value 1 for periods after the volatility shock (i.e., $t=3$ and $t=4$ ), zero otherwise, and PRE_SHOCK stands for a dummy variable taking the value 1 for periods before the shock (i.e., $t=1$ and $t=2$ ), zero otherwise. The interaction terms (e.g., POST_SHOCK $\times$ UP) measure the combined effects of the shock phase (i.e., before or after the shock) and the respective treatment (i.e., UP or DOWN). Controls include a participant's risk tolerance, CRT score, age, and gender. Clustered standard errors on the participant-level are in parentheses. ${ }^{*}$ and ${ }^{* *}$ indicate the $5 \%$ - and the $0.5 \%$-significance levels, respectively.

\begin{tabular}{|c|c|c|c|c|c|c|c|c|}
\hline & \multicolumn{8}{|c|}{ Dependent variable: Optimistic minus Pessimistic Forecast } \\
\hline & \multicolumn{4}{|c|}{ Financial Professionals } & \multicolumn{4}{|c|}{ Students } \\
\hline & \multicolumn{2}{|c|}{ PRICES } & \multicolumn{2}{|c|}{ RETURNS } & \multicolumn{2}{|c|}{ PRICES } & \multicolumn{2}{|c|}{ RETURNS } \\
\hline & (1) & $(2)$ & (3) & (4) & (5) & (6) & (7) & (8) \\
\hline POST_SHOCK & $\begin{array}{l}2.824^{* *} \\
(0.768)\end{array}$ & $\begin{array}{c}2.824^{* *} \\
(0.769)\end{array}$ & $\begin{array}{c}0.891 \\
(0.508)\end{array}$ & $\begin{array}{c}0.891 \\
(0.509)\end{array}$ & $\begin{array}{l}4.002^{* *} \\
(0.699)\end{array}$ & $\begin{array}{l}4.002^{* *} \\
(0.700)\end{array}$ & $\begin{array}{c}1.123 \\
(0.826)\end{array}$ & $\begin{array}{c}1.123 \\
(0.827)\end{array}$ \\
\hline PRE_SHOCK $\times$ DOWN & $\begin{array}{r}-1.647^{*} \\
(0.761)\end{array}$ & $\begin{array}{r}-1.647^{*} \\
(0.762)\end{array}$ & $\begin{array}{c}-1.055 \\
(0.551)\end{array}$ & $\begin{array}{c}-1.055 \\
(0.552)\end{array}$ & $\begin{array}{c}4.528 \\
(5.296)\end{array}$ & $\begin{array}{c}4.528 \\
(5.304)\end{array}$ & $\begin{array}{c}0.629 \\
(0.825)\end{array}$ & $\begin{array}{c}0.629 \\
(0.826)\end{array}$ \\
\hline POST_SHOCK $\times$ DOWN & $\begin{array}{l}3.933^{* *} \\
(0.830)\end{array}$ & $\begin{array}{c}3.933^{* *} \\
(0.832)\end{array}$ & $\begin{array}{c}4.290^{* *} \\
(0.815)\end{array}$ & $\begin{array}{c}4.290^{* *} \\
(0.816)\end{array}$ & $\begin{array}{l}4.802^{* *} \\
(1.004)\end{array}$ & $\begin{array}{c}4.802^{* *} \\
(1.005)\end{array}$ & $\begin{array}{c}2.987^{* *} \\
(0.790)\end{array}$ & $\begin{array}{c}2.987^{* *} \\
(0.791)\end{array}$ \\
\hline PRE_SHOCK $\times$ UP & $\begin{array}{c}-0.966 \\
(0.733)\end{array}$ & $\begin{array}{c}-0.966 \\
(0.735)\end{array}$ & $\begin{array}{c}-1.058 \\
(0.556)\end{array}$ & $\begin{array}{c}-1.058 \\
(0.557)\end{array}$ & $\begin{array}{c}0.234 \\
(1.107)\end{array}$ & $\begin{array}{c}0.234 \\
(1.108)\end{array}$ & $\begin{array}{c}-0.338 \\
(0.715)\end{array}$ & $\begin{array}{c}-0.338 \\
(0.716)\end{array}$ \\
\hline POST_SHOCK $\times$ UP & $\begin{array}{c}0.102 \\
(0.662)\end{array}$ & $\begin{array}{c}0.102 \\
(0.664)\end{array}$ & $\begin{array}{c}0.262 \\
(0.808)\end{array}$ & $\begin{array}{c}0.262 \\
(0.810)\end{array}$ & $\begin{array}{c}-0.688 \\
(0.800)\end{array}$ & $\begin{array}{c}-0.688 \\
(0.801)\end{array}$ & $\begin{array}{c}0.798 \\
(0.743)\end{array}$ & $\begin{array}{c}0.798 \\
(0.744)\end{array}$ \\
\hline Constant & $\begin{array}{l}13.456^{* *} \\
(1.611)\end{array}$ & $\begin{array}{l}10.815 \\
(8.285)\end{array}$ & $\begin{array}{l}11.381^{* *} \\
(0.922)\end{array}$ & $\begin{array}{c}-1.854 \\
(5.781)\end{array}$ & $\begin{array}{l}12.234^{* *} \\
(1.074)\end{array}$ & $\begin{array}{l}14.567 \\
(8.681)\end{array}$ & $\begin{array}{l}11.298^{* *} \\
(0.966)\end{array}$ & $\begin{array}{l}18.082^{*} \\
(8.185)\end{array}$ \\
\hline Controls & No & Yes & No & Yes & No & Yes & No & Yes \\
\hline Observations & 1,188 & 1,188 & 1,236 & 1,236 & 1,584 & 1,584 & 1,800 & 1,800 \\
\hline $\mathrm{R}^{2}$ & 0.034 & 0.077 & 0.043 & 0.090 & 0.006 & 0.009 & 0.010 & 0.043 \\
\hline Adjusted $\mathrm{R}^{2}$ & 0.030 & 0.069 & 0.039 & 0.082 & 0.003 & 0.002 & 0.008 & 0.037 \\
\hline
\end{tabular}

Table C18: Ordinary least squares regressions on INVESTMENT for each participant pool (financial professionals and students) and each shock type. POST_SHOCK is a dummy variable taking the value 1 for periods after the volatility shock (i.e., decision at $t=3$ and $t=4$ ), zero otherwise, and PRE_SHOCK stands for a dummy variable taking the value 1 for periods before the shock (i.e., decision at $t=1$ and $t=2$ ), zero otherwise. The interaction terms (e.g., POST_SHOCK $\times$ RETURNS) measure the combined effects of the shock phase (i.e., before or after the shock) and the respective treatment (i.e., RETURNS). PRE_SHOCK and the presentation format PRICES act as the reference categories. Controls include a participant's risk tolerance, CRT score, age, and gender. Clustered standard errors on the participantlevel are in parentheses. ${ }^{*}$ and ${ }^{* *}$ indicate the $5 \%$ - and the $0.5 \%$-significance levels, respectively.

\begin{tabular}{|c|c|c|c|c|c|c|c|c|c|c|c|c|}
\hline & \multicolumn{12}{|c|}{ Dependent variable: INVESTMENT } \\
\hline & \multicolumn{6}{|c|}{ Financial Professionals } & \multicolumn{6}{|c|}{ Students } \\
\hline & \multicolumn{2}{|c|}{ Down } & \multicolumn{2}{|c|}{ STRAIGHT } & \multicolumn{2}{|c|}{ UP } & \multicolumn{2}{|c|}{ Down } & \multicolumn{2}{|c|}{ STRAIGHT } & \multicolumn{2}{|c|}{ UP } \\
\hline & (1) & (2) & (3) & (4) & (5) & (6) & (7) & (8) & (9) & (10) & (11) & (12) \\
\hline POST_SHOCK & $\begin{array}{l}8.977^{* *} \\
(1.779)\end{array}$ & $\begin{array}{l}8.977^{* * *} \\
(1.784)\end{array}$ & $\begin{array}{c}0.630 \\
(1.389)\end{array}$ & $\begin{array}{c}0.630 \\
(1.393)\end{array}$ & $\begin{array}{c}-7.645^{* *} \\
(2.124)\end{array}$ & $\begin{array}{c}-7.645^{* *} \\
(2.130)\end{array}$ & $\begin{array}{c}0.494 \\
(1.644)\end{array}$ & $\begin{array}{c}0.494 \\
(1.647)\end{array}$ & $\begin{array}{c}0.988 \\
(1.283)\end{array}$ & $\begin{array}{c}0.988 \\
(1.285)\end{array}$ & $\begin{array}{c}-3.715^{*} \\
(1.842)\end{array}$ & $\begin{array}{r}-3.715^{*} \\
(1.845)\end{array}$ \\
\hline PRE_SHOCK $\times$ RETURNS & $\begin{array}{r}8.645^{*} \\
(3.145)\end{array}$ & $\begin{array}{l}9.696^{* *} \\
(2.880)\end{array}$ & $\begin{array}{c}3.202 \\
(3.205)\end{array}$ & $\begin{array}{c}4.203 \\
(3.036)\end{array}$ & $\begin{array}{c}5.042 \\
(3.063)\end{array}$ & $\begin{array}{r}6.052^{*} \\
(2.872)\end{array}$ & $\begin{array}{c}1.121 \\
(3.040)\end{array}$ & $\begin{array}{c}0.156 \\
(2.728)\end{array}$ & $\begin{array}{c}3.614 \\
(2.967)\end{array}$ & $\begin{array}{c}2.640 \\
(2.707)\end{array}$ & $\begin{array}{c}1.479 \\
(3.045)\end{array}$ & $\begin{array}{c}0.749 \\
(2.769)\end{array}$ \\
\hline POST_SHOCK $\times$ RETURNS & $\begin{array}{c}5.083 \\
(2.987)\end{array}$ & $\begin{array}{r}6.134^{*} \\
(2.794)\end{array}$ & $\begin{array}{c}3.587 \\
(3.485)\end{array}$ & $\begin{array}{c}4.588 \\
(3.308)\end{array}$ & $\begin{array}{c}5.407 \\
(3.900)\end{array}$ & $\begin{array}{c}6.416 \\
(3.706)\end{array}$ & $\begin{array}{c}1.469 \\
(3.602)\end{array}$ & $\begin{array}{c}0.505 \\
(3.119)\end{array}$ & $\begin{array}{c}3.168 \\
(3.406)\end{array}$ & $\begin{array}{c}2.195 \\
(3.066)\end{array}$ & $\begin{array}{c}4.502 \\
(3.405)\end{array}$ & $\begin{array}{c}3.772 \\
(3.081)\end{array}$ \\
\hline Constant & $\begin{array}{l}71.556^{* * *} \\
(2.255)\end{array}$ & $\begin{array}{c}41.395^{* *} \\
(10.705)\end{array}$ & $\begin{array}{l}74.937^{* * *} \\
(2.264)\end{array}$ & $\begin{array}{l}43.183^{* *} \\
(11.444)\end{array}$ & $\begin{array}{l}75.518^{* *} \\
(2.283)\end{array}$ & $\begin{array}{c}46.997^{5 \times} \\
(12.062)\end{array}$ & $\begin{array}{l}58.295^{* *} \\
(2.210)\end{array}$ & $\begin{array}{c}25.293^{*} \\
(12.589)\end{array}$ & $\begin{array}{l}55.451^{* *} \\
(2.111)\end{array}$ & $\begin{array}{c}29.916^{*} \\
(11.093)\end{array}$ & $\begin{array}{l}55.640^{\text {*** }} \\
(2.207)\end{array}$ & $\begin{array}{c}20.027 \\
(11.968)\end{array}$ \\
\hline Controls & No & Yes & No & Yes & No & Yes & No & Yes & No & Yes & No & Yes \\
\hline Observations & 1,010 & 1,010 & 1,010 & 1,010 & 1,010 & 1,010 & 1,410 & 1,410 & 1,410 & 1,410 & 1,410 & 1,410 \\
\hline $\mathrm{R}^{2}$ & 0.042 & 0.176 & 0.004 & 0.134 & 0.027 & 0.134 & 0.001 & 0.171 & 0.004 & 0.150 & 0.004 & 0.134 \\
\hline Adjusted $\mathrm{R}^{2}$ & 0.039 & 0.169 & 0.001 & 0.127 & 0.024 & 0.127 & -0.002 & 0.166 & 0.002 & 0.145 & 0.002 & 0.129 \\
\hline
\end{tabular}


Table C19: Ordinary least squares regressions on RECOMMENDATION for each participant pool (financial professionals and students) and each shock type (DOWN, STRAIGHT, and UP). POST_SHOCK is a dummy variable taking the value 1 for periods after the volatility shock (i.e., decision at $t=3$ and $\mathrm{t}=4$ ), zero otherwise, and PRE_SHOCK stands for a dummy variable taking the value 1 for periods before the shock (i.e., decision at $t=1$ and $\mathrm{t}=2$ ), zero otherwise. The interaction terms (e.g., POST_SHOCK $\times$ RETURNS) measure the combined effects of the shock phase (i.e., before or after the shock) and the respective treatment (i.e., RETURNS). PRE_SHOCK and the presentation format PRICES act as the reference categories. Controls include a participant's risk tolerance, CRT score, age, and gender. Clustered standard errors on the participant-level are in parentheses. ${ }^{*}$ and ${ }^{* *}$ indicate the $5 \%$ - and the $0.5 \%$-significance levels, respectively.

\begin{tabular}{|c|c|c|c|c|c|c|c|c|c|c|c|c|}
\hline & \multicolumn{12}{|c|}{ Dependent variable: RECOMMENDATION } \\
\hline & \multicolumn{6}{|c|}{ Financial Professionals } & \multicolumn{6}{|c|}{ Students } \\
\hline & \multicolumn{2}{|c|}{ Down } & \multicolumn{2}{|c|}{ STRAIGHT } & \multicolumn{2}{|c|}{ up } & \multicolumn{2}{|c|}{ Down } & \multicolumn{2}{|c|}{ STRAIGHT } & \multicolumn{2}{|c|}{ UP } \\
\hline & (1) & (2) & (3) & (4) & (5) & (6) & (7) & (8) & (9) & (10) & (11) & (12) \\
\hline POST_SHOCK & $\begin{array}{l}0.283^{* * *} \\
(0.066)\end{array}$ & $\begin{array}{c}0.283^{* *} \\
(0.066)\end{array}$ & $\begin{array}{c}-0.106 \\
(0.062)\end{array}$ & $\begin{array}{c}-0.106 \\
(0.062)\end{array}$ & $\begin{array}{l}-0.227^{* *} \\
(0.060)\end{array}$ & $\begin{array}{l}-0.227^{* *} \\
(0.060)\end{array}$ & $\begin{array}{c}0.080 \\
(0.074)\end{array}$ & $\begin{array}{c}0.080 \\
(0.074)\end{array}$ & $\begin{array}{l}-0.144^{*} \\
(0.060)\end{array}$ & $\begin{array}{c}-0.144^{*} \\
(0.060)\end{array}$ & $\begin{array}{l}-0.254^{* * *} \\
(0.066)\end{array}$ & $\begin{array}{c}-0.254^{* *} \\
(0.066)\end{array}$ \\
\hline PRE_SHOCK $\times$ RETURNS & $\begin{array}{c}0.031 \\
(0.069)\end{array}$ & $\begin{array}{c}0.037 \\
(0.069)\end{array}$ & $\begin{array}{c}-0.018 \\
(0.072)\end{array}$ & $\begin{array}{c}-0.007 \\
(0.071)\end{array}$ & $\begin{array}{c}-0.002 \\
(0.072)\end{array}$ & $\begin{array}{c}0.011 \\
(0.071)\end{array}$ & $\begin{array}{c}-0.173^{*} \\
(0.063)\end{array}$ & $\begin{array}{l}-0.185^{* *} \\
(0.065)\end{array}$ & $\begin{array}{l}-0.211^{* *} \\
(0.068)\end{array}$ & $\begin{array}{c}-0.213^{* *} \\
(0.069)\end{array}$ & $\begin{array}{l}-0.090 \\
(0.063)\end{array}$ & $\begin{array}{c}-0.088 \\
(0.063)\end{array}$ \\
\hline POST_SHOCK $\times$ RETURNS & $\begin{array}{c}-0.179 \\
(0.113)\end{array}$ & $\begin{array}{l}-0.173 \\
(0.113)\end{array}$ & $\begin{array}{l}-0.116 \\
(0.097)\end{array}$ & $\begin{array}{c}-0.105 \\
(0.096)\end{array}$ & $\begin{array}{c}0.060 \\
(0.085)\end{array}$ & $\begin{array}{c}0.073 \\
(0.083)\end{array}$ & $\begin{array}{c}-0.456^{* *} \\
(0.100)\end{array}$ & $\begin{array}{l}-0.467^{* *} \\
(0.094)\end{array}$ & $\begin{array}{l}-0.307^{* *} \\
(0.076)\end{array}$ & $\begin{array}{l}-0.309^{* *} \\
(0.075)\end{array}$ & $\begin{array}{c}0.158^{*} \\
(0.075)\end{array}$ & $\begin{array}{c}0.159^{*} \\
(0.075)\end{array}$ \\
\hline Constant & $\begin{array}{l}3.202^{* *} \\
(0.049)\end{array}$ & $\begin{array}{l}2.933^{* *} \\
(0.296)\end{array}$ & $\begin{array}{c}3.222^{* * *} \\
(0.052)\end{array}$ & $\begin{array}{c}3.040^{* * *} \\
(0.223)\end{array}$ & $\begin{array}{l}3.187^{* *} \\
(0.045)\end{array}$ & $\begin{array}{c}3.196^{* *} \\
(0.192)\end{array}$ & $\begin{array}{l}3.000^{* *} \\
(0.042)\end{array}$ & $\begin{array}{c}2.629^{* * *} \\
(0.245)\end{array}$ & $\begin{array}{l}3.008^{* *} \\
(0.045)\end{array}$ & $\begin{array}{c}2.709^{* *} \\
(0.243)\end{array}$ & $\begin{array}{l}2.913^{* * *} \\
(0.044)\end{array}$ & $\begin{array}{c}2.839^{* * *} \\
(0.244)\end{array}$ \\
\hline Controls & No & Yes & No & Yes & No & Yes & No & Yes & No & Yes & No & Yes \\
\hline Observations & 808 & 808 & 808 & 808 & 808 & 808 & 1,128 & 1,128 & 1,128 & 1,128 & 1,128 & 1,128 \\
\hline $\mathrm{R}^{2}$ & 0.018 & 0.034 & 0.016 & 0.044 & 0.021 & 0.058 & 0.037 & 0.083 & 0.041 & 0.052 & 0.011 & 0.012 \\
\hline Adjusted $R^{2}$ & 0.014 & 0.024 & 0.012 & 0.034 & 0.017 & 0.049 & 0.034 & 0.077 & 0.039 & 0.045 & 0.008 & 0.005 \\
\hline
\end{tabular}

Table C20: Ordinary least squares regressions on SATISFACTION for each participant pool (financial professionals and students) and each shock type (DOWN, STRAIGHT, and UP). POST_SHOCK is a dummy variable taking the value 1 for periods after the volatility shock (i.e., decision at $t=3$ and $\mathrm{t}=4$ ), zero otherwise, and PRE_SHOCK stands for a dummy variable taking the value 1 for periods before the shock (i.e., decision at $t=1$ and $\mathrm{t}=2$ ), zero otherwise. The interaction terms (e.g., POST_SHOCK $\times$ RETURNS) measure the combined effects of the shock phase (i.e., before or after the shock) and the respective treatment (i.e., RETURNS). PRE_SHOCK and the presentation format PRICES act as the reference categories. Controls include a participant's risk tolerance, CRT score, age, and gender. Clustered standard errors on the participant-level are in parentheses. ${ }^{*}$ and ${ }^{* *}$ indicate the $5 \%$ - and the $0.5 \%$-significance levels, respectively.

\begin{tabular}{|c|c|c|c|c|c|c|c|c|c|c|c|c|}
\hline & \multicolumn{12}{|c|}{ Dependent variable: SATISFACTION } \\
\hline & \multicolumn{6}{|c|}{ Financial Professionals } & \multicolumn{6}{|c|}{ Students } \\
\hline & \multicolumn{2}{|c|}{ Down } & \multicolumn{2}{|c|}{ STRAIGHT } & \multicolumn{2}{|c|}{ uP } & \multicolumn{2}{|c|}{ Down } & \multicolumn{2}{|c|}{ STRAIGHT } & \multicolumn{2}{|c|}{ UP } \\
\hline & (1) & (2) & (3) & (4) & (5) & (6) & (7) & (8) & (9) & (10) & (11) & (12) \\
\hline POST_SHOCK & $\begin{array}{c}-1.101^{* *} \\
(0.076)\end{array}$ & $\begin{array}{c}-1.102^{* * *} \\
(0.076)\end{array}$ & $\begin{array}{c}-0.490^{* *} \\
(0.075)\end{array}$ & $\begin{array}{c}-0.490^{* *} \\
(0.075)\end{array}$ & $\begin{array}{c}0.813^{* *} \\
(0.086)\end{array}$ & $\begin{array}{c}0.813^{* *} \\
(0.086)\end{array}$ & $\begin{array}{c}-1.163^{* * *} \\
(0.091)\end{array}$ & $\begin{array}{c}-1.163^{* * *} \\
(0.091)\end{array}$ & $\begin{array}{c}-0.738^{* *} \\
(0.096)\end{array}$ & $\begin{array}{c}-0.738^{* * *} \\
(0.096)\end{array}$ & $\begin{array}{c}0.928^{* *} \\
(0.095)\end{array}$ & $\begin{array}{c}0.928^{* *} \\
(0.096)\end{array}$ \\
\hline PRE_SHOCK $\times$ RETURNS & $\begin{array}{c}-0.069 \\
(0.116)\end{array}$ & $\begin{array}{c}-0.062 \\
(0.121)\end{array}$ & $\begin{array}{c}0.017 \\
(0.130)\end{array}$ & $\begin{array}{c}0.022 \\
(0.136)\end{array}$ & $\begin{array}{c}-0.166 \\
(0.125)\end{array}$ & $\begin{array}{c}-0.147 \\
(0.126)\end{array}$ & $\begin{array}{c}-0.110 \\
(0.098)\end{array}$ & $\begin{array}{c}-0.095 \\
(0.099)\end{array}$ & $\begin{array}{c}-0.007 \\
(0.090)\end{array}$ & $\begin{array}{c}-0.004 \\
(0.091)\end{array}$ & $\begin{array}{c}-0.014 \\
(0.101)\end{array}$ & $\begin{array}{c}-0.023 \\
(0.102)\end{array}$ \\
\hline POST_SHOCK $\times$ RETURNS & $\begin{array}{c}0.038 \\
(0.155)\end{array}$ & $\begin{array}{c}0.045 \\
(0.160)\end{array}$ & $\begin{array}{c}-0.389^{*} \\
(0.166)\end{array}$ & $\begin{array}{c}-0.385^{*} \\
(0.174)\end{array}$ & $\begin{array}{c}-0.331^{*} \\
(0.138)\end{array}$ & $\begin{array}{c}-0.310^{*} \\
(0.140)\end{array}$ & $\begin{array}{c}0.312^{* *} \\
(0.097)\end{array}$ & $\begin{array}{c}0.327^{* *} \\
(0.096)\end{array}$ & $\begin{array}{c}-0.199 \\
(0.129)\end{array}$ & $\begin{array}{c}-0.195 \\
(0.129)\end{array}$ & $\begin{array}{r}-0.294^{*} \\
(0.124)\end{array}$ & $\begin{array}{c}-0.302^{*} \\
(0.123)\end{array}$ \\
\hline Constant & $\begin{array}{c}0.015 \\
(0.072)\end{array}$ & $\begin{array}{c}-0.155 \\
(0.450)\end{array}$ & $\begin{array}{c}0.076 \\
(0.081)\end{array}$ & $\begin{array}{c}-0.167 \\
(0.456)\end{array}$ & $\begin{array}{r}0.162^{*} \\
(0.074)\end{array}$ & $\begin{array}{c}0.238 \\
(0.350)\end{array}$ & $\begin{array}{c}-0.435^{* *} \\
(0.066)\end{array}$ & $\begin{array}{c}-0.681^{*} \\
(0.315)\end{array}$ & $\begin{array}{c}-0.274^{* *} \\
(0.056)\end{array}$ & $\begin{array}{c}-0.707 \\
(0.432)\end{array}$ & $\begin{array}{c}-0.311^{* *} \\
(0.077)\end{array}$ & $\begin{array}{c}-1.074^{* *} \\
(0.365)\end{array}$ \\
\hline Controls & No & Yes & No & Yes & No & Yes & No & Yes & No & Yes & No & Yes \\
\hline Observations & 804 & 804 & 804 & 804 & 805 & 805 & 1,125 & 1,125 & 1,125 & 1,125 & 1,124 & 1,124 \\
\hline $\mathrm{R}^{2}$ & 0.094 & 0.098 & 0.060 & 0.065 & 0.059 & 0.067 & 0.089 & 0.092 & 0.079 & 0.081 & 0.050 & 0.058 \\
\hline Adjusted $\mathrm{R}^{2}$ & 0.091 & 0.089 & 0.057 & 0.056 & 0.056 & 0.058 & 0.087 & 0.085 & 0.076 & 0.075 & 0.047 & 0.051 \\
\hline
\end{tabular}


Table C21: Ordinary least squares regressions on RISK PERCEPTION for each participant pool (financial professionals and students) and each shock type (DOWN, STRAIGHT, and UP). POST_SHOCK is a dummy variable taking the value 1 for periods after the volatility shock (i.e., decision at $t=3$ and $t=4$ ), zero otherwise, and PRE_SHOCK stands for a dummy variable taking the value 1 for periods before the shock (i.e., decision at $t=1$ and $t=2$ ), zero otherwise. The interaction terms (e.g., POST_SHOCK $\times$ RETURNS) measure the combined effects of the shock phase (i.e., before or after the shock) and the respective treatment (i.e., RETURNS). PRE_SHOCK and the presentation format PRICES act as the reference categories. Controls include a participant's risk tolerance, CRT score, age, and gender. Clustered standard errors on the participant-level are in parentheses. ${ }^{*}$ and ${ }^{* *}$ indicate the $5 \%$ - and the $0.5 \%$-significance levels, respectively.

\begin{tabular}{|c|c|c|c|c|c|c|c|c|c|c|c|c|}
\hline & \multicolumn{12}{|c|}{ Dependent variable: RISK PERCEPTION } \\
\hline & \multicolumn{6}{|c|}{ Financial Professionals } & \multicolumn{6}{|c|}{ Students } \\
\hline & \multicolumn{2}{|c|}{ Down } & \multicolumn{2}{|c|}{ STRAIGHT } & \multicolumn{2}{|c|}{ uP } & \multicolumn{2}{|c|}{ Down } & \multicolumn{2}{|c|}{ STRAIGHT } & \multicolumn{2}{|c|}{ UP } \\
\hline & (1) & (2) & (3) & (4) & (5) & (6) & (7) & (8) & (9) & (10) & (11) & (12) \\
\hline POST_SHOCK & $\begin{array}{c}1.139^{* *} \\
(0.115)\end{array}$ & $\begin{array}{l}1.136^{* *} \\
(0.115)\end{array}$ & $\begin{array}{c}0.870^{* *} \\
(0.085)\end{array}$ & $\begin{array}{c}0.870^{* *} \\
(0.085)\end{array}$ & $\begin{array}{c}0.829^{* *} \\
(0.095)\end{array}$ & $\begin{array}{c}0.828^{* *} \\
(0.095)\end{array}$ & $\begin{array}{c}1.425^{* *} \\
(0.102)\end{array}$ & $\begin{array}{c}1.426^{* *} \\
(0.102)\end{array}$ & $\begin{array}{c}0.683^{* * *} \\
(0.092)\end{array}$ & $\begin{array}{c}0.683^{* *} \\
(0.093)\end{array}$ & $\begin{array}{c}0.285^{*} \\
(0.103)\end{array}$ & $\begin{array}{c}0.288^{*} \\
(0.103)\end{array}$ \\
\hline PRE_SHOCK $\times$ RETURNS & $\begin{array}{c}0.477^{* *} \\
(0.167)\end{array}$ & $\begin{array}{c}0.463^{*} \\
(0.166)\end{array}$ & $\begin{array}{c}0.568^{* *} \\
(0.161)\end{array}$ & $\begin{array}{c}0.533^{* *} \\
(0.160)\end{array}$ & $\begin{array}{c}0.328 \\
(0.168)\end{array}$ & $\begin{array}{c}0.292 \\
(0.168)\end{array}$ & $\begin{array}{c}0.677^{* *} \\
(0.129)\end{array}$ & $\begin{array}{c}0.673^{* *} \\
(0.129)\end{array}$ & $\begin{array}{c}0.430^{* *} \\
(0.127)\end{array}$ & $\begin{array}{c}0.429^{* *} \\
(0.128)\end{array}$ & $\begin{array}{c}0.410^{* *} \\
(0.131)\end{array}$ & $\begin{array}{c}0.434^{* *} \\
(0.132)\end{array}$ \\
\hline POST_SHOCK $\times$ RETURNS & $\begin{array}{c}0.105 \\
(0.155)\end{array}$ & $\begin{array}{c}0.096 \\
(0.154)\end{array}$ & $\begin{array}{c}0.218 \\
(0.156)\end{array}$ & $\begin{array}{c}0.179 \\
(0.155)\end{array}$ & $\begin{array}{c}0.100 \\
(0.147)\end{array}$ & $\begin{array}{c}0.068 \\
(0.145)\end{array}$ & $\begin{array}{c}-0.072 \\
(0.133)\end{array}$ & $\begin{array}{c}-0.076 \\
(0.133)\end{array}$ & $\begin{array}{c}-0.071 \\
(0.127)\end{array}$ & $\begin{array}{c}-0.071 \\
(0.128)\end{array}$ & $\begin{array}{c}0.082 \\
(0.142)\end{array}$ & $\begin{array}{c}0.105 \\
(0.141)\end{array}$ \\
\hline Constant & $\begin{array}{c}4.183^{* *} \\
(0.110)\end{array}$ & $\begin{array}{c}3.197^{* *} \\
(0.488)\end{array}$ & $\begin{array}{c}4.250^{* *} \\
(0.108)\end{array}$ & $\begin{array}{l}3.194^{* *} \\
(0.467)\end{array}$ & $\begin{array}{l}4.376^{* *} \\
(0.115)\end{array}$ & $\begin{array}{c}2.888^{* *} \\
(0.509)\end{array}$ & $\begin{array}{l}4.034^{* *} \\
(0.102)\end{array}$ & $\begin{array}{c}3.638^{* * *} \\
(0.546)\end{array}$ & $\begin{array}{c}4.465^{* *} \\
(0.091)\end{array}$ & $\begin{array}{c}4.088^{* *} \\
(0.502)\end{array}$ & $\begin{array}{c}4.313^{* *} \\
(0.105)\end{array}$ & $\begin{array}{c}3.682^{* *} \\
(0.541)\end{array}$ \\
\hline Controls & No & Yes & No & Yes & No & Yes & No & Yes & No & Yes & No & Yes \\
\hline Observations & 800 & 800 & 791 & 791 & 801 & 801 & 1,115 & 1,115 & 1,113 & 1,113 & 1,108 & 1,108 \\
\hline $\mathrm{R}^{2}$ & 0.128 & 0.157 & 0.092 & 0.114 & 0.081 & 0.119 & 0.147 & 0.150 & 0.037 & 0.045 & 0.014 & 0.025 \\
\hline Adjusted $R^{2}$ & 0.125 & 0.148 & 0.089 & 0.105 & 0.077 & 0.110 & 0.145 & 0.144 & 0.035 & 0.038 & 0.011 & 0.018 \\
\hline
\end{tabular}

Table C22: Ordinary least squares regressions on DIFF_PRICES for each participant pool (financial professionals and students) and each shock type (DOWN, STRAIGHT, and UP). POST_SHOCK is a dummy variable taking the value 1 for periods after the volatility shock (i.e., decision at $t=3$ and $\mathrm{t}=4$ ), zero otherwise, and PRE_SHOCK stands for a dummy variable taking the value 1 for periods before the shock (i.e., decision at $t=1$ and $\mathrm{t}=2$ ), zero otherwise. The interaction terms (e.g., POST_SHOCK $\times$ RETURNS) measure the combined effects of the shock phase (i.e., before or after the shock) and the respective treatment (i.e., RETURNS). PRE_SHOCK and the presentation format PRICES act as the reference categories. Controls include a participant's risk tolerance, CRT score, age, and gender. Clustered standard errors on the participant-level are in parentheses. ${ }^{*}$ and ${ }^{* *}$ indicate the $5 \%$ - and the $0.5 \%$-significance levels, respectively.

\begin{tabular}{|c|c|c|c|c|c|c|c|c|c|c|c|c|}
\hline & \multicolumn{12}{|c|}{ Dependent variable: PRICE FORECAST } \\
\hline & \multicolumn{6}{|c|}{ Financial Professionals } & \multicolumn{6}{|c|}{ Students } \\
\hline & \multicolumn{2}{|c|}{ Down } & \multicolumn{2}{|c|}{ STRAIGHT } & \multicolumn{2}{|c|}{ up } & \multicolumn{2}{|c|}{ Down } & \multicolumn{2}{|c|}{ STRAIGHT } & \multicolumn{2}{|c|}{ up } \\
\hline & (1) & (2) & (3) & (4) & (5) & (6) & (7) & (8) & (9) & (10) & (11) & (12) \\
\hline POST_SHOCK & $\begin{array}{c}-13.482^{* *} \\
(0.828)\end{array}$ & $\begin{array}{c}-13.482^{* *} \\
(0.830)\end{array}$ & $\begin{array}{c}1.415^{*} \\
(0.720)\end{array}$ & $\begin{array}{c}1.415 \\
(0.723)\end{array}$ & $\begin{array}{l}15.108^{* *} \\
(1.016)\end{array}$ & $\begin{array}{l}15.108^{* * *} \\
(1.019)\end{array}$ & $\begin{array}{c}-13.878^{* *} \\
(1.167)\end{array}$ & $\begin{array}{c}-13.878^{* *} \\
(1.170)\end{array}$ & $\begin{array}{c}1.681^{*} \\
(0.739)\end{array}$ & $\begin{array}{c}1.681^{*} \\
(0.740)\end{array}$ & $\begin{array}{l}14.281^{* *} \\
(0.944)\end{array}$ & $\begin{array}{l}14.281^{* *} \\
(0.946)\end{array}$ \\
\hline PRE_SHOCK $\times$ RETURNS & $\begin{array}{c}1.650 \\
(1.159)\end{array}$ & $\begin{array}{c}1.738 \\
(1.302)\end{array}$ & $\begin{array}{c}1.934 \\
(1.144)\end{array}$ & $\begin{array}{c}2.314 \\
(1.365)\end{array}$ & $\begin{array}{c}0.891 \\
(1.366)\end{array}$ & $\begin{array}{c}1.106 \\
(1.617)\end{array}$ & $\begin{array}{l}7.620^{\text {** }} \\
(1.756)\end{array}$ & $\begin{array}{l}7.318^{* *} \\
(1.684)\end{array}$ & $\begin{array}{c}7.522^{* *} \\
(1.795)\end{array}$ & $\begin{array}{l}7.097^{* *} \\
(1.714)\end{array}$ & $\begin{array}{l}8.558^{* *} \\
(1.722)\end{array}$ & $\begin{array}{l}8.171^{* * *} \\
(1.618)\end{array}$ \\
\hline POST_SHOCK $\times$ RETURNS & $\begin{array}{c}-1.472 \\
(0.987)\end{array}$ & $\begin{array}{l}-1.384 \\
(1.080)\end{array}$ & $\begin{array}{c}0.358 \\
(1.090)\end{array}$ & $\begin{array}{c}0.738 \\
(1.290)\end{array}$ & $\begin{array}{c}1.819 \\
(1.309)\end{array}$ & $\begin{array}{c}2.034 \\
(1.530)\end{array}$ & $\begin{array}{c}1.010 \\
(1.453)\end{array}$ & $\begin{array}{c}0.709 \\
(1.375)\end{array}$ & $\begin{array}{l}5.841^{* *} \\
(1.705)\end{array}$ & $\begin{array}{l}5.415^{* *} \\
(1.595)\end{array}$ & $\begin{array}{l}11.666^{* *} \\
(1.814)\end{array}$ & $\begin{array}{l}11.279^{* *} \\
(1.699)\end{array}$ \\
\hline Constant & $\begin{array}{l}99.934^{* *} \\
(1.146)\end{array}$ & $\begin{array}{c}100.471^{* *} \\
(1.631)\end{array}$ & $\begin{array}{l}98.928^{* *} \\
(1.132)\end{array}$ & $\begin{array}{l}99.221^{* *} \\
(1.852)\end{array}$ & $\begin{array}{c}100.560^{* *} \\
(1.356)\end{array}$ & $\begin{array}{l}99.445^{* *} \\
(2.383)\end{array}$ & $\begin{array}{l}99.437^{* *} \\
(1.064)\end{array}$ & $\begin{array}{c}101.015^{* *} \\
(6.232)\end{array}$ & $\begin{array}{l}98.453^{* * *} \\
(1.302)\end{array}$ & $\begin{array}{c}108.440^{* *} \\
(7.716)\end{array}$ & $\begin{array}{l}97.895^{* *} \\
(1.176)\end{array}$ & $\begin{array}{c}100.284^{* *} \\
(7.468)\end{array}$ \\
\hline Controls & No & Yes & No & Yes & No & Yes & No & Yes & No & Yes & No & Yes \\
\hline Observations & 808 & 808 & 808 & 808 & 808 & 808 & 1,128 & 1,128 & 1,128 & 1,128 & 1,128 & 1,128 \\
\hline $\mathrm{R}^{2}$ & 0.466 & 0.474 & 0.008 & 0.079 & 0.351 & 0.377 & 0.278 & 0.296 & 0.043 & 0.071 & 0.260 & 0.277 \\
\hline Adjusted $\mathrm{R}^{2}$ & 0.464 & 0.469 & 0.005 & 0.069 & 0.349 & 0.370 & 0.276 & 0.291 & 0.040 & 0.064 & 0.258 & 0.272 \\
\hline
\end{tabular}


Table C23: Ordinary least squares regressions on RETURN FORECAST for each participant pool (financial professionals and students) and each shock type (DOWN, STRAIGHT, and UP). POST_SHOCK is a dummy variable taking the value 1 for periods after the volatility shock (i.e., decision at $t=3$ and $\mathrm{t}=4$ ), zero otherwise, and PRE_SHOCK stands for a dummy variable taking the value 1 for periods before the shock (i.e., decision at $t=1$ and $\mathrm{t}=2$ ), zero otherwise. The interaction terms (e.g., POST_SHOCK $\times$ RETURNS) measure the combined effects of the shock phase (i.e., before or after the shock) and the respective treatment (i.e., RETURNS). PRE_SHOCK and the presentation format PRICES act as the reference categories. Controls include a participant's risk tolerance, CRT score, age, and gender. Clustered standard errors on the participant-level are in parentheses. ${ }^{*}$ and ${ }^{* *}$ indicate the $5 \%$ - and the $0.5 \%$-significance levels, respectively.

\begin{tabular}{|c|c|c|c|c|c|c|c|c|c|c|c|c|}
\hline & \multicolumn{12}{|c|}{ Dependent variable: RETURN FORECAST } \\
\hline & \multicolumn{6}{|c|}{ Financial Professionals } & \multicolumn{6}{|c|}{ Students } \\
\hline & \multicolumn{2}{|c|}{ Down } & \multicolumn{2}{|c|}{ STRAIGHT } & \multicolumn{2}{|c|}{ UP } & \multicolumn{2}{|c|}{ Down } & \multicolumn{2}{|c|}{ STRAIGHT } & \multicolumn{2}{|c|}{ UP } \\
\hline & (1) & (2) & (3) & (4) & (5) & (6) & (7) & (8) & (9) & (10) & (11) & (12) \\
\hline POST_SHOCK & $\begin{array}{c}5.106^{* * *} \\
(0.843)\end{array}$ & $\begin{array}{l}5.106^{* * *} \\
(0.845)\end{array}$ & $\begin{array}{c}1.697^{*} \\
(0.725)\end{array}$ & $\begin{array}{c}1.697^{*} \\
(0.728)\end{array}$ & $\begin{array}{c}-0.481 \\
(0.973)\end{array}$ & $\begin{array}{c}-0.481 \\
(0.976)\end{array}$ & $\begin{array}{c}4.509^{* * *} \\
(1.300)\end{array}$ & $\begin{array}{c}4.509^{* *} \\
(1.303)\end{array}$ & $\begin{array}{c}2.019^{*} \\
(0.744)\end{array}$ & $\begin{array}{c}2.019^{*} \\
(0.746)\end{array}$ & $\begin{array}{c}-0.899 \\
(0.873)\end{array}$ & $\begin{array}{c}-0.899 \\
(0.875)\end{array}$ \\
\hline PRE_SHOCK $\times$ RETURNS & $\begin{array}{c}1.544 \\
(1.155)\end{array}$ & $\begin{array}{c}1.615 \\
(1.312)\end{array}$ & $\begin{array}{c}1.948 \\
(1.157)\end{array}$ & $\begin{array}{c}2.315 \\
(1.382)\end{array}$ & $\begin{array}{c}0.846 \\
(1.378)\end{array}$ & $\begin{array}{c}1.069 \\
(1.615)\end{array}$ & $\begin{array}{l}7.545^{* *} \\
(1.751)\end{array}$ & $\begin{array}{c}7.197^{\text {*** }} \\
(1.677)\end{array}$ & $\begin{array}{c}7.578^{* * *} \\
(1.808)\end{array}$ & $\begin{array}{c}7.145^{* * *} \\
(1.728)\end{array}$ & $\begin{array}{c}8.539^{* *} \\
(1.723)\end{array}$ & $\begin{array}{l}8.168^{* *} \\
(1.621)\end{array}$ \\
\hline POST_SHOCK $\times$ RETURNS & $\begin{array}{c}-2.055 \\
(1.149)\end{array}$ & $\begin{array}{c}-1.983 \\
(1.257)\end{array}$ & $\begin{array}{c}0.462 \\
(1.096)\end{array}$ & $\begin{array}{c}0.829 \\
(1.300)\end{array}$ & $\begin{array}{c}1.516 \\
(1.075)\end{array}$ & $\begin{array}{c}1.739 \\
(1.301)\end{array}$ & $\begin{array}{c}1.061 \\
(1.721)\end{array}$ & $\begin{array}{c}0.712 \\
(1.629)\end{array}$ & $\begin{array}{c}5.859^{* * *} \\
(1.703)\end{array}$ & $\begin{array}{c}5.426^{* * *} \\
(1.591)\end{array}$ & $\begin{array}{l}10.094^{* *} \\
(1.550)\end{array}$ & $\begin{array}{c}9.723^{* * *} \\
(1.440)\end{array}$ \\
\hline Constant & $\begin{array}{c}0.211 \\
(1.145)\end{array}$ & $\begin{array}{c}0.210 \\
(1.592)\end{array}$ & $\begin{array}{c}-0.237 \\
(1.145)\end{array}$ & $\begin{array}{c}0.398 \\
(1.805)\end{array}$ & $\begin{array}{c}0.654 \\
(1.370)\end{array}$ & $\begin{array}{c}0.184 \\
(2.170)\end{array}$ & $\begin{array}{c}-0.281 \\
(1.069)\end{array}$ & $\begin{array}{c}2.610 \\
(6.758)\end{array}$ & $\begin{array}{c}-0.704 \\
(1.310)\end{array}$ & $\begin{array}{c}8.763 \\
(7.774)\end{array}$ & $\begin{array}{c}-2.066 \\
(1.177)\end{array}$ & $\begin{array}{c}0.043 \\
(6.918)\end{array}$ \\
\hline Controls & No & Yes & No & Yes & No & Yes & No & Yes & No & Yes & No & Yes \\
\hline Observations & 808 & 808 & 808 & 808 & 808 & 808 & 1,128 & 1,128 & 1,128 & 1,128 & 1,128 & 1,128 \\
\hline $\mathrm{R}^{2}$ & 0.044 & 0.059 & 0.011 & 0.083 & 0.004 & 0.040 & 0.029 & 0.055 & 0.044 & 0.072 & 0.092 & 0.115 \\
\hline Adjusted $\mathrm{R}^{2}$ & 0.041 & 0.049 & 0.007 & 0.073 & 0.0002 & 0.031 & 0.027 & 0.048 & 0.041 & 0.066 & 0.089 & 0.108 \\
\hline
\end{tabular}

Table C24: Ordinary least squares regressions on Optimistic minus Pessimistic Forecasts for each participant pool (financial professionals and students) and each shock type (DOWN, STRAIGHT, and UP). POST_SHOCK is a dummy variable taking the value 1 for periods after the volatility shock (i.e., decision at $t=3$ and $\mathrm{t}=4$ ), zero otherwise, and PRE_SHOCK stands for a dummy variable taking the value 1 for periods before the shock (i.e., decision at $t=1$ and $\mathrm{t}=2$ ), zero otherwise. The interaction terms (e.g., POST_SHOCK $\times$ RETURNS) measure the combined effects of the shock phase (i.e., before or after the shock) and the respective treatment (i.e., RETURNS). PRE_SHOCK and the presentation format PRICES act as the reference categories. Controls include a participant's risk tolerance, CRT score, age, and gender. Clustered standard errors on the participant-level are in parentheses. ${ }^{*}$ and ${ }^{* *}$ indicate the $5 \%$ - and the $0.5 \%$-significance levels, respectively.

\begin{tabular}{|c|c|c|c|c|c|c|c|c|c|c|c|c|}
\hline & \multicolumn{12}{|c|}{ Dependent variable: Optimistic minus Pessimistic Forecast } \\
\hline & \multicolumn{6}{|c|}{ Financial Professionals } & \multicolumn{6}{|c|}{ Students } \\
\hline & \multicolumn{2}{|c|}{ Down } & \multicolumn{2}{|c|}{ STRAIGHT } & \multicolumn{2}{|c|}{ UP } & \multicolumn{2}{|c|}{ Down } & \multicolumn{2}{|c|}{ STRAIGHT } & \multicolumn{2}{|c|}{ UP } \\
\hline & (1) & (2) & (3) & (4) & (5) & (6) & (7) & (8) & (9) & (10) & (11) & (12) \\
\hline POST_SHOCK & $\begin{array}{l}8.403^{* *} \\
(0.779)\end{array}$ & $\begin{array}{l}8.403^{* *} \\
(0.781)\end{array}$ & $\begin{array}{l}2.824^{* * *} \\
(0.766)\end{array}$ & $\begin{array}{l}2.824^{* * *} \\
(0.768)\end{array}$ & $\begin{array}{c}3.892^{* *} \\
(0.688)\end{array}$ & $\begin{array}{c}3.892^{* *} \\
(0.690)\end{array}$ & $\begin{array}{c}4.276 \\
(5.306)\end{array}$ & $\begin{array}{c}4.276 \\
(5.318)\end{array}$ & $\begin{array}{l}4.002^{* *} \\
(0.697)\end{array}$ & $\begin{array}{l}4.002^{* *} \\
(0.699)\end{array}$ & $\begin{array}{l}3.079^{* * *} \\
(0.748)\end{array}$ & $\begin{array}{l}3.079^{* *} \\
(0.750)\end{array}$ \\
\hline PRE_SHOCK $\times$ RETURNS & $\begin{array}{c}-1.484 \\
(1.600)\end{array}$ & $\begin{array}{c}-1.469 \\
(1.586)\end{array}$ & $\begin{array}{c}-2.075 \\
(1.851)\end{array}$ & $\begin{array}{l}-2.092 \\
(1.847)\end{array}$ & $\begin{array}{c}-2.167 \\
(1.763)\end{array}$ & $\begin{array}{l}-2.199 \\
(1.787)\end{array}$ & $\begin{array}{c}-4.835 \\
(5.912)\end{array}$ & $\begin{array}{c}-4.832 \\
(5.716)\end{array}$ & $\begin{array}{c}-0.936 \\
(1.442)\end{array}$ & $\begin{array}{c}-1.219 \\
(1.428)\end{array}$ & $\begin{array}{l}-1.509 \\
(1.796)\end{array}$ & $\begin{array}{c}-1.755 \\
(1.807)\end{array}$ \\
\hline POST_SHOCK $\times$ RETURNS & $\begin{array}{c}-3.652 \\
(2.074)\end{array}$ & $\begin{array}{l}-3.636 \\
(2.046)\end{array}$ & $\begin{array}{c}-4.009^{*} \\
(1.733)\end{array}$ & $\begin{array}{c}-4.026^{*} \\
(1.720)\end{array}$ & $\begin{array}{r}-3.848^{*} \\
(1.692)\end{array}$ & $\begin{array}{c}-3.880^{*} \\
(1.725)\end{array}$ & $\begin{array}{c}-5.630^{* *} \\
(1.782)\end{array}$ & $\begin{array}{c}-5.627^{* *} \\
(1.792)\end{array}$ & $\begin{array}{c}-3.815^{*} \\
(1.745)\end{array}$ & $\begin{array}{c}-4.098^{*} \\
(1.739)\end{array}$ & $\begin{array}{l}-2.329 \\
(1.481)\end{array}$ & $\begin{array}{l}-2.575 \\
(1.482)\end{array}$ \\
\hline Constant & $\begin{array}{l}11.809^{* * *} \\
(1.349)\end{array}$ & $\begin{array}{c}2.946 \\
(5.250)\end{array}$ & $\begin{array}{l}13.456^{* *} \\
(1.607)\end{array}$ & $\begin{array}{l}6.725 \\
(5.603)\end{array}$ & $\begin{array}{l}12.490^{* *} \\
(1.566)\end{array}$ & $\begin{array}{c}6.328 \\
(4.772)\end{array}$ & $\begin{array}{l}16.762^{* *} \\
(5.781)\end{array}$ & $\begin{array}{l}16.043^{*} \\
(7.472)\end{array}$ & $\begin{array}{l}12.234^{* *} \\
(1.072)\end{array}$ & $\begin{array}{l}20.342^{* *} \\
(5.392)\end{array}$ & $\begin{array}{l}12.469^{\text {s** }} \\
(1.436)\end{array}$ & $\begin{array}{l}16.093^{*} \\
(6.766)\end{array}$ \\
\hline Controls & No & Yes & No & Yes & No & Yes & No & Yes & No & Yes & No & Yes \\
\hline Observations & 808 & 808 & 808 & 808 & 808 & 808 & 1,128 & 1,128 & 1,128 & 1,128 & 1,128 & 1,128 \\
\hline $\mathrm{R}^{2}$ & 0.079 & 0.114 & 0.020 & 0.054 & 0.030 & 0.056 & 0.005 & 0.014 & 0.016 & 0.030 & 0.013 & 0.024 \\
\hline Adjusted $\mathrm{R}^{2}$ & 0.075 & 0.105 & 0.016 & 0.044 & 0.027 & 0.046 & 0.003 & 0.007 & 0.014 & 0.023 & 0.011 & 0.017 \\
\hline
\end{tabular}


Table C25: Ordinary least squares regressions on INVESTMENT for each participant pool (financial professionals and students) and each shock type (DOWN, STRAIGHT, and UP). POST_SHOCK is a dummy variable taking the value 1 for periods after the volatility shock (i.e., decision at $t=3$ and $\mathrm{t}=4$ ), zero otherwise, and PRE_SHOCK stands for a dummy variable taking the value 1 for periods before the shock (i.e., decision at $t=1$ and $\mathrm{t}=2$ ), zero otherwise. The interaction terms (e.g., POST_SHOCK $\times$ RETURNS) measure the combined effects of the shock phase (i.e., before or after the shock) and the respective treatment (i.e., RETURNS). PRE_SHOCK and the presentation format PRICES act as the reference categories. Controls include a participant's risk tolerance, CRT score, age, and gender. Clustered standard errors on the participant-level are in parentheses. ${ }^{*}$ and ${ }^{*}$ indicate the $5 \%$ - and the $0.5 \%$-significance levels, respectively.

\begin{tabular}{|c|c|c|c|c|c|c|c|c|c|c|c|c|}
\hline & \multicolumn{12}{|c|}{ Dependent variable: INVESTMENT } \\
\hline & \multicolumn{6}{|c|}{ Financial Professionals } & \multicolumn{6}{|c|}{ Students } \\
\hline & \multicolumn{2}{|c|}{ Down } & \multicolumn{2}{|c|}{ STRAIGHT } & \multicolumn{2}{|c|}{ UP } & \multicolumn{2}{|c|}{ Down } & \multicolumn{2}{|c|}{ STRAIGHT } & \multicolumn{2}{|c|}{ UP } \\
\hline & (1) & (2) & (3) & (4) & (5) & (6) & (7) & (8) & (9) & (10) & (11) & (12) \\
\hline$t=1$ & $\begin{array}{c}1.563 \\
(1.521)\end{array}$ & $\begin{array}{c}1.563 \\
(1.526)\end{array}$ & $\begin{array}{c}-0.324 \\
(2.074)\end{array}$ & $\begin{array}{c}-0.324 \\
(2.080)\end{array}$ & $\begin{array}{c}1.749 \\
(2.252)\end{array}$ & $\begin{array}{l}1.749 \\
(2.260)\end{array}$ & $\begin{array}{r}-3.967^{*} \\
(1.616)\end{array}$ & $\begin{array}{c}-3.967^{*} \\
(1.620)\end{array}$ & $\begin{array}{c}-4.259^{*} \\
(1.617)\end{array}$ & $\begin{array}{r}-4.259^{*} \\
(1.620)\end{array}$ & $\begin{array}{l}1.600 \\
(1.979)\end{array}$ & $\begin{array}{c}1.600 \\
(1.983)\end{array}$ \\
\hline$t=3$ & $\begin{array}{l}9.725^{* *} \\
(2.172)\end{array}$ & $\begin{array}{l}9.725^{* *} \\
(2.179)\end{array}$ & $\begin{array}{c}0.575 \\
(2.104)\end{array}$ & $\begin{array}{c}0.575 \\
(2.110)\end{array}$ & $\begin{array}{c}-8.766^{* *} \\
(2.709)\end{array}$ & $\begin{array}{c}-8.766^{* *} \\
(2.717)\end{array}$ & $\begin{array}{c}-1.870 \\
(2.143)\end{array}$ & $\begin{array}{c}-1.870 \\
(2.148)\end{array}$ & $\begin{array}{c}-0.876 \\
(1.295)\end{array}$ & $\begin{array}{c}-0.876 \\
(1.298)\end{array}$ & $\begin{array}{c}-2.030 \\
(2.571)\end{array}$ & $\begin{array}{c}-2.030 \\
(2.577)\end{array}$ \\
\hline$t=4$ & $\begin{array}{c}9.640^{\text {*** }} \\
(2.523)\end{array}$ & $\begin{array}{l}9.640^{* * *} \\
(2.531)\end{array}$ & $\begin{array}{l}1.104 \\
(2.544)\end{array}$ & $\begin{array}{l}1.104 \\
(2.552)\end{array}$ & $\begin{array}{c}-4.313 \\
(2.879)\end{array}$ & $\begin{array}{c}-4.313 \\
(2.888)\end{array}$ & $\begin{array}{c}-0.272 \\
(1.812)\end{array}$ & $\begin{array}{c}-0.272 \\
(1.816)\end{array}$ & $\begin{array}{c}-0.140 \\
(1.727)\end{array}$ & $\begin{array}{c}-0.140 \\
(1.731)\end{array}$ & $\begin{array}{c}-2.213 \\
(2.343)\end{array}$ & $\begin{array}{c}-2.213 \\
(2.348)\end{array}$ \\
\hline$t=2 \times$ RETURNS & $\begin{array}{l}10.673^{\text {k* }} \\
(3.537)\end{array}$ & $\begin{array}{l}11.842^{* *} \\
(3.246)\end{array}$ & $\begin{array}{c}2.811 \\
(3.765)\end{array}$ & $\begin{array}{c}4.063 \\
(3.609)\end{array}$ & $\begin{array}{c}5.423 \\
(3.574)\end{array}$ & $\begin{array}{c}6.498 \\
(3.493)\end{array}$ & $\begin{array}{c}0.485 \\
(3.447)\end{array}$ & $\begin{array}{c}-0.480 \\
(3.079)\end{array}$ & $\begin{array}{c}1.088 \\
(3.447)\end{array}$ & $\begin{array}{c}0.129 \\
(3.219)\end{array}$ & $\begin{array}{c}2.131 \\
(3.703)\end{array}$ & $\begin{array}{c}1.320 \\
(3.540)\end{array}$ \\
\hline$t=1 \times$ RETURNS & $\begin{array}{c}6.926 \\
(3.609)\end{array}$ & $\begin{array}{c}8.094^{*} \\
(3.395)\end{array}$ & $\begin{array}{c}6.082 \\
(3.521)\end{array}$ & $\begin{array}{r}7.334^{*} \\
(3.363)\end{array}$ & $\begin{array}{c}4.994 \\
(3.454)\end{array}$ & $\begin{array}{c}6.069 \\
(3.218)\end{array}$ & $\begin{array}{c}1.564 \\
(3.430)\end{array}$ & $\begin{array}{c}0.598 \\
(3.218)\end{array}$ & $\begin{array}{c}5.353 \\
(3.357)\end{array}$ & $\begin{array}{c}4.394 \\
(3.118)\end{array}$ & $\begin{array}{c}2.481 \\
(3.398)\end{array}$ & $\begin{array}{c}1.670 \\
(3.075)\end{array}$ \\
\hline$t=3 \times$ RETURNS & $\begin{array}{c}4.823 \\
(3.265)\end{array}$ & $\begin{array}{c}5.991 \\
(3.077)\end{array}$ & $\begin{array}{c}2.866 \\
(3.771)\end{array}$ & $\begin{array}{c}4.118 \\
(3.614)\end{array}$ & $\begin{array}{c}3.898 \\
(4.400)\end{array}$ & $\begin{array}{c}4.973 \\
(4.271)\end{array}$ & $\begin{array}{c}1.210 \\
(3.870)\end{array}$ & $\begin{array}{c}0.245 \\
(3.366)\end{array}$ & $\begin{array}{c}1.063 \\
(3.635)\end{array}$ & $\begin{array}{c}0.104 \\
(3.338)\end{array}$ & $\begin{array}{c}0.683 \\
(3.588)\end{array}$ & $\begin{array}{c}-0.128 \\
(3.303)\end{array}$ \\
\hline$t=4 \times$ RETURNS & $\begin{array}{c}5.344 \\
(3.203)\end{array}$ & $\begin{array}{c}6.512^{*} \\
(3.031)\end{array}$ & $\begin{array}{c}4.308 \\
(3.778)\end{array}$ & $\begin{array}{c}5.560 \\
(3.622)\end{array}$ & $\begin{array}{c}6.916 \\
(4.078)\end{array}$ & $\begin{array}{c}7.991^{*} \\
(3.855)\end{array}$ & $\begin{array}{c}1.729 \\
(3.810)\end{array}$ & $\begin{array}{c}0.763 \\
(3.406)\end{array}$ & $\begin{array}{c}5.273 \\
(3.684)\end{array}$ & $\begin{array}{c}4.314 \\
(3.351)\end{array}$ & $\begin{array}{c}8.320^{*} \\
(3.703)\end{array}$ & $\begin{array}{r}7.510^{*} \\
(3.395)\end{array}$ \\
\hline Constant & $\begin{array}{l}70.850^{\text {** }} \\
(2.658)\end{array}$ & $\begin{array}{c}43.078^{* *} \\
(11.063)\end{array}$ & $\begin{array}{l}74.727^{* * *} \\
(2.662)\end{array}$ & $\begin{array}{l}46.219^{* *} \\
(11.476)\end{array}$ & $\begin{array}{l}74.412^{* *} \\
(2.645)\end{array}$ & $\begin{array}{c}46.628^{* *} \\
(12.323)\end{array}$ & $\begin{array}{l}59.859^{* * *} \\
(2.452)\end{array}$ & $\begin{array}{c}24.220 \\
(12.980)\end{array}$ & $\begin{array}{l}56.946^{* *} \\
(2.419)\end{array}$ & $\begin{array}{r}29.430^{*} \\
(11.956)\end{array}$ & $\begin{array}{l}54.046^{* *} \\
(2.690)\end{array}$ & $\begin{array}{c}19.543 \\
(12.825)\end{array}$ \\
\hline Controls & No & Yes & No & Yes & No & Yes & No & Yes & No & Yes & No & Yes \\
\hline Observations & 808 & 808 & 808 & 808 & 808 & 808 & 1,128 & 1,128 & 1,128 & 1,128 & 1,128 & 1,128 \\
\hline $\mathrm{R}^{2}$ & 0.043 & 0.180 & 0.007 & 0.142 & 0.033 & 0.138 & 0.003 & 0.185 & 0.007 & 0.159 & 0.009 & 0.143 \\
\hline Adjusted $\mathrm{R}^{2}$ & 0.034 & 0.167 & -0.001 & 0.129 & 0.024 & 0.125 & -0.003 & 0.176 & 0.0005 & 0.150 & 0.003 & 0.133 \\
\hline
\end{tabular}


Table C26: Ordinary least squares regressions on RECOMMENDATION for each participant pool (financial professionals and students) and each shock type (DOWN, STRAIGHT, and UP). POST_SHOCK is a dummy variable taking the value 1 for periods after the volatility shock (i.e., decision at $t=3$ and $\mathrm{t}=4$ ), zero otherwise, and PRE_SHOCK stands for a dummy variable taking the value 1 for periods before the shock (i.e., decision at $t=1$ and $\mathrm{t}=2$ ), zero otherwise. The interaction terms (e.g., POST_SHOCK $\times$ RETURNS) measure the combined effects of the shock phase (i.e., before or after the shock) and the respective treatment (i.e., RETURNS). PRE_SHOCK and the presentation format PRICES act as the reference categories. Controls include a participant's risk tolerance, CRT score, age, and gender. Clustered standard errors on the participant-level are in parentheses. ${ }^{*}$ and ${ }^{* *}$ indicate the $5 \%$ - and the $0.5 \%$-significance levels, respectively.

\begin{tabular}{|c|c|c|c|c|c|c|c|c|c|c|c|c|}
\hline & \multicolumn{12}{|c|}{ Dependent variable: RECOMMENDATION } \\
\hline & \multicolumn{6}{|c|}{ Financial Professionals } & \multicolumn{6}{|c|}{ Students } \\
\hline & \multicolumn{2}{|c|}{ DOWN } & \multicolumn{2}{|c|}{ STRAight } & \multicolumn{2}{|c|}{ UP } & \multicolumn{2}{|c|}{ DOWN } & \multicolumn{2}{|c|}{ STRAIGHT } & \multicolumn{2}{|c|}{ UP } \\
\hline & (1) & (2) & (3) & (4) & $(5)$ & (6) & (7) & (8) & (9) & (10) & (11) & (12) \\
\hline$t=1$ & $\begin{array}{c}0.040 \\
(0.064)\end{array}$ & $\begin{array}{c}0.040 \\
(0.064)\end{array}$ & $\begin{array}{c}-0.061 \\
(0.076)\end{array}$ & $\begin{array}{l}-0.061 \\
(0.076)\end{array}$ & $\begin{array}{l}-0.030 \\
(0.084)\end{array}$ & $\begin{array}{c}-0.030 \\
(0.085)\end{array}$ & $\begin{array}{c}-0.030 \\
(0.082)\end{array}$ & $\begin{array}{c}-0.030 \\
(0.082)\end{array}$ & $\begin{array}{c}0.015 \\
(0.085)\end{array}$ & $\begin{array}{c}0.015 \\
(0.086)\end{array}$ & $\begin{array}{c}0.205^{*} \\
(0.096)\end{array}$ & $\begin{array}{c}0.205^{*} \\
(0.096)\end{array}$ \\
\hline$t=3$ & $\begin{array}{c}0.354^{* *} \\
(0.089)\end{array}$ & $\begin{array}{c}0.354^{* * *} \\
(0.089)\end{array}$ & $\begin{array}{r}-0.152^{*} \\
(0.077)\end{array}$ & $\begin{array}{l}-0.152^{*} \\
(0.077)\end{array}$ & $\begin{array}{l}-0.273^{* *} \\
(0.082)\end{array}$ & $\begin{array}{c}-0.273^{* * *} \\
(0.083)\end{array}$ & $\begin{array}{c}0.159 \\
(0.106)\end{array}$ & $\begin{array}{c}0.159 \\
(0.107)\end{array}$ & $\begin{array}{c}-0.114 \\
(0.085)\end{array}$ & $\begin{array}{c}-0.114 \\
(0.085)\end{array}$ & $\begin{array}{c}-0.318^{* * *} \\
(0.111)\end{array}$ & $\begin{array}{r}-0.318^{* * *} \\
(0.111)\end{array}$ \\
\hline$t=4$ & $\begin{array}{c}0.253^{* *} \\
(0.077)\end{array}$ & $\begin{array}{l}0.253^{* * *} \\
(0.077)\end{array}$ & $\begin{array}{c}-0.121 \\
(0.072)\end{array}$ & $\begin{array}{l}-0.121 \\
(0.073)\end{array}$ & $\begin{array}{l}-0.212^{* *} \\
(0.069)\end{array}$ & $\begin{array}{c}-0.212^{* * *} \\
(0.070)\end{array}$ & $\begin{array}{l}-0.030 \\
(0.079)\end{array}$ & $\begin{array}{c}-0.030 \\
(0.079)\end{array}$ & $\begin{array}{c}-0.159^{*} \\
(0.080)\end{array}$ & $\begin{array}{r}-0.159^{*} \\
(0.081)\end{array}$ & $\begin{array}{c}0.015 \\
(0.073)\end{array}$ & $\begin{array}{c}0.015 \\
(0.073)\end{array}$ \\
\hline$t=2 \times$ RETURNS & $\begin{array}{c}0.003 \\
(0.089)\end{array}$ & $\begin{array}{c}0.009 \\
(0.087)\end{array}$ & $\begin{array}{c}0.039 \\
(0.077)\end{array}$ & $\begin{array}{c}0.050 \\
(0.077)\end{array}$ & $\begin{array}{c}0.012 \\
(0.089)\end{array}$ & $\begin{array}{c}0.025 \\
(0.089)\end{array}$ & $\begin{array}{c}-0.148 \\
(0.091)\end{array}$ & $\begin{array}{c}-0.160 \\
(0.091)\end{array}$ & $\begin{array}{c}-0.133 \\
(0.089)\end{array}$ & $\begin{array}{c}-0.135 \\
(0.091)\end{array}$ & $\begin{array}{c}-0.057 \\
(0.089)\end{array}$ & $\begin{array}{c}-0.056 \\
(0.089)\end{array}$ \\
\hline$t=1 \times$ RETURNS & $\begin{array}{c}0.059 \\
(0.087)\end{array}$ & $\begin{array}{c}0.066 \\
(0.089)\end{array}$ & $\begin{array}{c}-0.075 \\
(0.098)\end{array}$ & $\begin{array}{c}-0.064 \\
(0.096)\end{array}$ & $\begin{array}{l}-0.016 \\
(0.094)\end{array}$ & $\begin{array}{c}-0.003 \\
(0.092)\end{array}$ & $\begin{array}{r}-0.198^{*} \\
(0.083)\end{array}$ & $\begin{array}{c}-0.209^{*} \\
(0.086)\end{array}$ & $\begin{array}{c}-0.288^{* *} \\
(0.099)\end{array}$ & $\begin{array}{c}-0.290^{* *} \\
(0.099)\end{array}$ & $\begin{array}{c}-0.122 \\
(0.089)\end{array}$ & $\begin{array}{c}-0.120 \\
(0.090)\end{array}$ \\
\hline$t=3 \times$ RETURNS & $\begin{array}{r}-0.322^{*} \\
(0.153)\end{array}$ & $\begin{array}{c}-0.315^{*} \\
(0.153)\end{array}$ & $\begin{array}{c}-0.198 \\
(0.111)\end{array}$ & $\begin{array}{l}-0.187 \\
(0.110)\end{array}$ & $\begin{array}{l}-0.007 \\
(0.118)\end{array}$ & $\begin{array}{c}0.006 \\
(0.117)\end{array}$ & $\begin{array}{c}-0.768^{* *} \\
(0.150)\end{array}$ & $\begin{array}{c}-0.779^{* *} \\
(0.143)\end{array}$ & $\begin{array}{c}-0.346^{* *} \\
(0.094)\end{array}$ & $\begin{array}{c}-0.348^{* *} \\
(0.093)\end{array}$ & $\begin{array}{c}0.348^{*} \\
(0.132)\end{array}$ & $\begin{array}{c}0.349^{*} \\
(0.131)\end{array}$ \\
\hline$t=4 \times$ RETURNS & $\begin{array}{c}-0.036 \\
(0.109)\end{array}$ & $\begin{array}{c}-0.030 \\
(0.109)\end{array}$ & $\begin{array}{c}-0.034 \\
(0.106)\end{array}$ & $\begin{array}{l}-0.023 \\
(0.105)\end{array}$ & $\begin{array}{c}0.127 \\
(0.081)\end{array}$ & $\begin{array}{c}0.140 \\
(0.079)\end{array}$ & $\begin{array}{c}-0.145 \\
(0.088)\end{array}$ & $\begin{array}{c}-0.156 \\
(0.088)\end{array}$ & $\begin{array}{c}-0.268^{* * *} \\
(0.090)\end{array}$ & $\begin{array}{c}-0.269^{* *} \\
(0.089)\end{array}$ & $\begin{array}{c}-0.032 \\
(0.080)\end{array}$ & $\begin{array}{c}-0.031 \\
(0.081)\end{array}$ \\
\hline Constant & $\begin{array}{l}3.182^{* *} \\
(0.053)\end{array}$ & $\begin{array}{l}2.913^{* * *} \\
(0.299)\end{array}$ & $\begin{array}{c}3.253^{* * *} \\
(0.056)\end{array}$ & $\begin{array}{c}3.070^{* *} \\
(0.225)\end{array}$ & $\begin{array}{c}3.202^{* * *} \\
(0.061)\end{array}$ & $\begin{array}{l}3.211^{* *} \\
(0.193)\end{array}$ & $\begin{array}{c}3.015^{* *} \\
(0.061)\end{array}$ & $\begin{array}{l}2.644^{* * *} \\
(0.250)\end{array}$ & $\begin{array}{l}3.000^{* * *} \\
(0.058)\end{array}$ & $\begin{array}{c}2.702^{* *} \\
(0.248)\end{array}$ & $\begin{array}{l}2.811^{* * *} \\
(0.060)\end{array}$ & $\begin{array}{c}2.737^{\text {**t }} \\
(0.244)\end{array}$ \\
\hline Controls & No & Yes & No & Yes & No & Yes & No & Yes & No & Yes & No & Yes \\
\hline Observations & 808 & 808 & 808 & 808 & 808 & 808 & 1,128 & 1,128 & 1,128 & 1,128 & 1,128 & 1,128 \\
\hline $\mathrm{R}^{2}$ & 0.023 & 0.039 & 0.025 & 0.053 & 0.027 & 0.064 & 0.055 & 0.101 & 0.044 & 0.054 & 0.026 & 0.027 \\
\hline Adjusted $\mathrm{R}^{2}$ & 0.015 & 0.025 & 0.016 & 0.039 & 0.019 & 0.050 & 0.049 & 0.091 & 0.038 & 0.044 & 0.019 & 0.016 \\
\hline
\end{tabular}


Table C27: Ordinary least squares regressions on SATISFACTION for each participant pool (financial professionals and students) and each shock type (DOWN, STRAIGHT, and UP). POST_SHOCK is a dummy variable taking the value 1 for periods after the volatility shock (i.e., decision at $t=3$ and $\mathrm{t}=4$ ), zero otherwise, and PRE_SHOCK stands for a dummy variable taking the value 1 for periods before the shock (i.e., decision at $t=1$ and $\mathrm{t}=2$ ), zero otherwise. The interaction terms (e.g., POST_SHOCK $\times$ RETURNS) measure the combined effects of the shock phase (i.e., before or after the shock) and the respective treatment (i.e., RETURNS). PRE_SHOCK and the presentation format PRICES act as the reference categories. Controls include a participant's risk tolerance, CRT score, age, and gender. Clustered standard errors on the participant-level are in parentheses. * and ${ }^{* *}$ indicate the $5 \%$ - and the $0.5 \%$-significance levels, respectively.

\begin{tabular}{|c|c|c|c|c|c|c|c|c|c|c|c|c|}
\hline & \multicolumn{12}{|c|}{ Dependent variable: SATISFACTION } \\
\hline & \multicolumn{6}{|c|}{ Financial Professionals } & \multicolumn{6}{|c|}{ Students } \\
\hline & \multicolumn{2}{|c|}{ Down } & \multicolumn{2}{|c|}{ STRAIGHT } & \multicolumn{2}{|c|}{ UP } & \multicolumn{2}{|c|}{ Down } & \multicolumn{2}{|c|}{ STRAIGHT } & \multicolumn{2}{|c|}{ UP } \\
\hline & (1) & (2) & (3) & (4) & (5) & (6) & (7) & (8) & (9) & (10) & (11) & (12) \\
\hline$t=1$ & $\begin{array}{c}0.313 \\
(0.221)\end{array}$ & $\begin{array}{c}0.313 \\
(0.221)\end{array}$ & $\begin{array}{c}-1.970^{* * *} \\
(0.138)\end{array}$ & $\begin{array}{c}-1.970^{* *} \\
(0.138)\end{array}$ & $\begin{array}{c}-0.222 \\
(0.229)\end{array}$ & $\begin{array}{c}-0.222 \\
(0.229)\end{array}$ & $\begin{array}{c}0.458^{*} \\
(0.220)\end{array}$ & $\begin{array}{r}0.457^{*} \\
(0.221)\end{array}$ & $\begin{array}{l}-2.360^{* * *} \\
(0.134)\end{array}$ & $\begin{array}{c}-2.360^{* *} \\
(0.135)\end{array}$ & $\begin{array}{c}-0.288 \\
(0.242)\end{array}$ & $\begin{array}{l}-0.288 \\
(0.242)\end{array}$ \\
\hline$t=3$ & $\begin{array}{c}-1.990^{* *} \\
(0.150)\end{array}$ & $\begin{array}{c}-1.990^{\text {*** }} \\
(0.150)\end{array}$ & $\begin{array}{c}-1.515^{* *} \\
(0.132)\end{array}$ & $\begin{array}{c}-1.515^{* *} \\
(0.133)\end{array}$ & $\begin{array}{l}1.452^{* *} \\
(0.174)\end{array}$ & $\begin{array}{l}1.451^{* * *} \\
(0.174)\end{array}$ & $\begin{array}{c}-1.919^{* * *} \\
(0.149)\end{array}$ & $\begin{array}{c}-1.920^{* *} \\
(0.149)\end{array}$ & $\begin{array}{l}-1.811^{* * *} \\
(0.147)\end{array}$ & $\begin{array}{c}-1.811^{* *} \\
(0.147)\end{array}$ & $\begin{array}{l}1.939^{* *} \\
(0.191)\end{array}$ & $\begin{array}{l}1.939^{* * *} \\
(0.191)\end{array}$ \\
\hline$t=4$ & $\begin{array}{c}0.111 \\
(0.161)\end{array}$ & $\begin{array}{c}0.111 \\
(0.161)\end{array}$ & $\begin{array}{c}-1.434^{* * *} \\
(0.121)\end{array}$ & $\begin{array}{c}-1.434^{* *} \\
(0.122)\end{array}$ & $\begin{array}{c}-0.040 \\
(0.151)\end{array}$ & $\begin{array}{c}-0.040 \\
(0.151)\end{array}$ & $\begin{array}{c}0.050 \\
(0.156)\end{array}$ & $\begin{array}{c}0.050 \\
(0.157)\end{array}$ & $\begin{array}{l}-2.016^{* * *} \\
(0.138)\end{array}$ & $\begin{array}{c}-2.017^{* *} \\
(0.138)\end{array}$ & $\begin{array}{c}-0.371^{*} \\
(0.162)\end{array}$ & $\begin{array}{c}-0.371^{*} \\
(0.163)\end{array}$ \\
\hline$t=2 \times$ RETURNS & $\begin{array}{c}-0.295 \\
(0.211)\end{array}$ & $\begin{array}{c}-0.288 \\
(0.215)\end{array}$ & $\begin{array}{c}0.057 \\
(0.170)\end{array}$ & $\begin{array}{c}0.064 \\
(0.174)\end{array}$ & $\begin{array}{c}-0.079 \\
(0.203)\end{array}$ & $\begin{array}{c}-0.059 \\
(0.207)\end{array}$ & $\begin{array}{c}0.020 \\
(0.182)\end{array}$ & $\begin{array}{c}0.034 \\
(0.182)\end{array}$ & $\begin{array}{c}0.012 \\
(0.138)\end{array}$ & $\begin{array}{c}0.015 \\
(0.139)\end{array}$ & $\begin{array}{c}0.173 \\
(0.198)\end{array}$ & $\begin{array}{c}0.165 \\
(0.198)\end{array}$ \\
\hline$t=1 \times$ RETURNS & $\begin{array}{c}0.165 \\
(0.215)\end{array}$ & $\begin{array}{c}0.172 \\
(0.218)\end{array}$ & $\begin{array}{c}-0.013 \\
(0.183)\end{array}$ & $\begin{array}{c}-0.008 \\
(0.189)\end{array}$ & $\begin{array}{c}-0.256 \\
(0.219)\end{array}$ & $\begin{array}{c}-0.237 \\
(0.217)\end{array}$ & $\begin{array}{c}-0.241 \\
(0.177)\end{array}$ & $\begin{array}{l}-0.225 \\
(0.178)\end{array}$ & $\begin{array}{l}-0.025 \\
(0.121)\end{array}$ & $\begin{array}{c}-0.022 \\
(0.122)\end{array}$ & $\begin{array}{c}-0.203 \\
(0.187)\end{array}$ & $\begin{array}{c}-0.212 \\
(0.188)\end{array}$ \\
\hline$t=3 \times$ RETURNS & $\begin{array}{c}0.122 \\
(0.192)\end{array}$ & $\begin{array}{c}0.129 \\
(0.197)\end{array}$ & $\begin{array}{c}-0.322 \\
(0.202)\end{array}$ & $\begin{array}{c}-0.317 \\
(0.209)\end{array}$ & $\begin{array}{c}-0.210 \\
(0.209)\end{array}$ & $\begin{array}{c}-0.190 \\
(0.210)\end{array}$ & $\begin{array}{c}0.010 \\
(0.125)\end{array}$ & $\begin{array}{c}0.025 \\
(0.124)\end{array}$ & $\begin{array}{c}-0.164 \\
(0.165)\end{array}$ & $\begin{array}{l}-0.161 \\
(0.166)\end{array}$ & $\begin{array}{c}-0.086 \\
(0.190)\end{array}$ & $\begin{array}{l}-0.090 \\
(0.186)\end{array}$ \\
\hline$t=4 \times$ RETURNS & $\begin{array}{c}-0.048 \\
(0.199)\end{array}$ & $\begin{array}{c}-0.041 \\
(0.204)\end{array}$ & $\begin{array}{r}-0.456^{*} \\
(0.177)\end{array}$ & $\begin{array}{c}-0.453^{*} \\
(0.184)\end{array}$ & $\begin{array}{r}-0.468^{*} \\
(0.175)\end{array}$ & $\begin{array}{c}-0.448^{*} \\
(0.178)\end{array}$ & $\begin{array}{l}0.614^{* *} \\
(0.137)\end{array}$ & $\begin{array}{c}0.628^{* * *} \\
(0.137)\end{array}$ & $\begin{array}{c}-0.232 \\
(0.141)\end{array}$ & $\begin{array}{l}-0.228 \\
(0.141)\end{array}$ & $\begin{array}{c}-0.475^{* *} \\
(0.146)\end{array}$ & $\begin{array}{l}-0.484^{* * *} \\
(0.148)\end{array}$ \\
\hline Constant & $\begin{array}{c}-0.141 \\
(0.133) \\
\end{array}$ & $\begin{array}{c}-0.324 \\
(0.463) \\
\end{array}$ & $\begin{array}{c}1.061^{* *} \\
(0.102)\end{array}$ & $\begin{array}{c}0.819 \\
(0.471) \\
\end{array}$ & $\begin{array}{r}0.273^{*} \\
(0.124) \\
\end{array}$ & $\begin{array}{c}0.339 \\
(0.360) \\
\end{array}$ & $\begin{array}{c}-0.664^{* * *} \\
(0.125)\end{array}$ & $\begin{array}{c}-0.911^{*} \\
(0.333) \\
\end{array}$ & $\begin{array}{c}0.902^{* * *} \\
(0.092)\end{array}$ & $\begin{array}{c}0.464 \\
(0.449) \\
\end{array}$ & $\begin{array}{c}-0.167 \\
(0.141) \\
\end{array}$ & $\begin{array}{r}-0.982^{*} \\
(0.393) \\
\end{array}$ \\
\hline Controls & No & Yes & No & Yes & No & Yes & No & Yes & No & Yes & No & Yes \\
\hline Observations & 804 & 804 & 804 & 804 & 805 & 805 & 1,125 & 1,125 & 1,125 & 1,125 & 1,124 & 1,124 \\
\hline $\mathrm{R}^{2}$ & 0.284 & 0.287 & 0.277 & 0.282 & 0.195 & 0.203 & 0.350 & 0.352 & 0.389 & 0.391 & 0.305 & 0.314 \\
\hline Adjusted $\mathrm{R}^{2}$ & 0.278 & 0.276 & 0.271 & 0.271 & 0.188 & 0.190 & 0.345 & 0.345 & 0.385 & 0.385 & 0.301 & 0.306 \\
\hline
\end{tabular}


Table C28: Ordinary least squares regressions on RISK PERCEPTION for each participant pool (financial professionals and students) and each shock type (DOWN, STRAIGHT, and UP). POST_SHOCK is a dummy variable taking the value 1 for periods after the volatility shock (i.e., decision at $t=3$ and $\mathrm{t}=4$ ), zero otherwise, and PRE_SHOCK stands for a dummy variable taking the value 1 for periods before the shock (i.e., decision at $t=1$ and $\mathrm{t}=2$ ), zero otherwise. The interaction terms (e.g., POST_SHOCK $\times$ RETURNS) measure the combined effects of the shock phase (i.e., before or after the shock) and the respective treatment (i.e., RETURNS). PRE_SHOCK and the presentation format PRICES act as the reference categories. Controls include a participant's risk tolerance, CRT score, age, and gender. Clustered standard errors on the participant-level are in parentheses. * and ${ }^{* *}$ indicate the $5 \%$ - and the $0.5 \%$-significance levels, respectively.

\begin{tabular}{|c|c|c|c|c|c|c|c|c|c|c|c|c|}
\hline & \multicolumn{12}{|c|}{ Dependent variable: RISK PERCEPTION } \\
\hline & \multicolumn{6}{|c|}{ Financial Professionals } & \multicolumn{6}{|c|}{ Students } \\
\hline & \multicolumn{2}{|c|}{ Down } & \multicolumn{2}{|c|}{ STRAIGHT } & \multicolumn{2}{|c|}{ UP } & \multicolumn{2}{|c|}{ Down } & \multicolumn{2}{|c|}{ STRAIGHT } & \multicolumn{2}{|c|}{ UP } \\
\hline & (1) & (2) & (3) & (4) & (5) & (6) & (7) & (8) & (9) & (10) & $(11)$ & $(12)$ \\
\hline$t=1$ & $\begin{array}{c}-0.140 \\
(0.090)\end{array}$ & $\begin{array}{c}-0.137 \\
(0.089)\end{array}$ & $\begin{array}{c}-0.051 \\
(0.081)\end{array}$ & $\begin{array}{c}-0.051 \\
(0.082)\end{array}$ & $\begin{array}{c}0.024 \\
(0.078)\end{array}$ & $\begin{array}{c}0.021 \\
(0.078)\end{array}$ & $\begin{array}{c}0.023 \\
(0.108)\end{array}$ & $\begin{array}{c}0.023 \\
(0.108)\end{array}$ & $\begin{array}{c}0.216^{*} \\
(0.095)\end{array}$ & $\begin{array}{r}0.218^{*} \\
(0.095)\end{array}$ & $\begin{array}{c}-0.010 \\
(0.104)\end{array}$ & $\begin{array}{c}-0.011 \\
(0.104)\end{array}$ \\
\hline$t=3$ & $\begin{array}{c}1.482^{* *} \\
(0.134)\end{array}$ & $\begin{array}{l}1.478^{* *} \\
(0.134)\end{array}$ & $\begin{array}{c}1.204^{* *} \\
(0.119)\end{array}$ & $\begin{array}{l}1.201^{* * *} \\
(0.120)\end{array}$ & $\begin{array}{c}1.214^{* *} \\
(0.110)\end{array}$ & $\begin{array}{c}1.212^{* *} \\
(0.111)\end{array}$ & $\begin{array}{l}1.915^{* *} \\
(0.127)\end{array}$ & $\begin{array}{c}1.916^{* *} \\
(0.127)\end{array}$ & $\begin{array}{c}1.407^{* *} \\
(0.113)\end{array}$ & $\begin{array}{l}1.406^{* *} \\
(0.113)\end{array}$ & $\begin{array}{c}0.527^{* *} \\
(0.127)\end{array}$ & $\begin{array}{c}0.529^{* * *} \\
(0.127)\end{array}$ \\
\hline$t=4$ & $\begin{array}{c}0.656^{* *} \\
(0.154)\end{array}$ & $\begin{array}{c}0.659^{* *} \\
(0.154)\end{array}$ & $\begin{array}{c}0.482^{* *} \\
(0.106)\end{array}$ & $\begin{array}{c}0.486^{\text {** }} \\
(0.106)\end{array}$ & $\begin{array}{c}0.473^{* *} \\
(0.108)\end{array}$ & $\begin{array}{c}0.469^{* *} \\
(0.107)\end{array}$ & $\begin{array}{c}0.962^{* *} \\
(0.144)\end{array}$ & $\begin{array}{c}0.963^{* *} \\
(0.144)\end{array}$ & $\begin{array}{c}0.178 \\
(0.128)\end{array}$ & $\begin{array}{c}0.179 \\
(0.128)\end{array}$ & $\begin{array}{c}0.029 \\
(0.130)\end{array}$ & $\begin{array}{c}0.031 \\
(0.130)\end{array}$ \\
\hline$t=2 \times$ RETURNS & $\begin{array}{c}0.444^{*} \\
(0.187)\end{array}$ & $\begin{array}{c}0.431^{*} \\
(0.187)\end{array}$ & $\begin{array}{c}0.626^{* *} \\
(0.173)\end{array}$ & $\begin{array}{c}0.591^{* *} \\
(0.171)\end{array}$ & $\begin{array}{c}0.287 \\
(0.179)\end{array}$ & $\begin{array}{c}0.249 \\
(0.178)\end{array}$ & $\begin{array}{c}0.741^{* *} \\
(0.160)\end{array}$ & $\begin{array}{c}0.737^{\text {k* }} \\
(0.159)\end{array}$ & $\begin{array}{c}0.380^{*} \\
(0.148)\end{array}$ & $\begin{array}{c}0.379^{*} \\
(0.149)\end{array}$ & $\begin{array}{c}0.331^{*} \\
(0.157)\end{array}$ & $\begin{array}{c}0.355^{*} \\
(0.157)\end{array}$ \\
\hline$t=1 \times$ RETURNS & $\begin{array}{c}0.512^{* *} \\
(0.173)\end{array}$ & $\begin{array}{c}0.495^{* *} \\
(0.171)\end{array}$ & $\begin{array}{c}0.508^{* *} \\
(0.172)\end{array}$ & $\begin{array}{c}0.475^{*} \\
(0.172)\end{array}$ & $\begin{array}{c}0.370^{*} \\
(0.181)\end{array}$ & $\begin{array}{c}0.335 \\
(0.180)\end{array}$ & $\begin{array}{c}0.615^{* *} \\
(0.141)\end{array}$ & $\begin{array}{c}0.609^{* *} \\
(0.142)\end{array}$ & $\begin{array}{c}0.482^{* *} \\
(0.144)\end{array}$ & $\begin{array}{c}0.481^{* *} \\
(0.145)\end{array}$ & $\begin{array}{c}0.490^{* *} \\
(0.143)\end{array}$ & $\begin{array}{c}0.514^{* *} \\
(0.144)\end{array}$ \\
\hline$t=3 \times$ RETURNS & $\begin{array}{c}0.197 \\
(0.165)\end{array}$ & $\begin{array}{c}0.191 \\
(0.163)\end{array}$ & $\begin{array}{c}0.335^{*} \\
(0.166)\end{array}$ & $\begin{array}{c}0.300 \\
(0.165)\end{array}$ & $\begin{array}{c}0.187 \\
(0.165)\end{array}$ & $\begin{array}{c}0.153 \\
(0.161)\end{array}$ & $\begin{array}{c}0.096 \\
(0.157)\end{array}$ & $\begin{array}{c}0.093 \\
(0.158)\end{array}$ & $\begin{array}{c}-0.270 \\
(0.143)\end{array}$ & $\begin{array}{c}-0.270 \\
(0.144)\end{array}$ & $\begin{array}{c}0.060 \\
(0.174)\end{array}$ & $\begin{array}{c}0.083 \\
(0.173)\end{array}$ \\
\hline$t=4 \times$ RETURNS & $\begin{array}{c}0.013 \\
(0.199)\end{array}$ & $\begin{array}{r}0.0003 \\
(0.199)\end{array}$ & $\begin{array}{c}0.091 \\
(0.199)\end{array}$ & $\begin{array}{c}0.047 \\
(0.199)\end{array}$ & $\begin{array}{c}0.005 \\
(0.176)\end{array}$ & $\begin{array}{c}-0.025 \\
(0.176)\end{array}$ & $\begin{array}{c}-0.235 \\
(0.170)\end{array}$ & $\begin{array}{c}-0.241 \\
(0.170)\end{array}$ & $\begin{array}{c}0.128 \\
(0.169)\end{array}$ & $\begin{array}{c}0.127 \\
(0.169)\end{array}$ & $\begin{array}{c}0.114 \\
(0.169)\end{array}$ & $\begin{array}{c}0.134 \\
(0.169)\end{array}$ \\
\hline Constant & $\begin{array}{c}4.253^{* *} \\
(0.123)\end{array}$ & $\begin{array}{c}3.286^{* *} \\
(0.497)\end{array}$ & $\begin{array}{c}4.276^{* * *} \\
(0.115)\end{array}$ & $\begin{array}{l}3.220^{* *} \\
(0.471)\end{array}$ & $\begin{array}{c}4.364^{* *} \\
(0.121)\end{array}$ & $\begin{array}{c}2.887^{* *} \\
(0.512)\end{array}$ & $\begin{array}{c}4.023^{* *} \\
(0.124)\end{array}$ & $\begin{array}{c}3.628^{* *} \\
(0.546)\end{array}$ & $\begin{array}{c}4.357^{* * *} \\
(0.103)\end{array}$ & $\begin{array}{c}3.970^{* *} \\
(0.509)\end{array}$ & $\begin{array}{l}4.318^{* *} \\
(0.120)\end{array}$ & $\begin{array}{c}3.688^{* * *} \\
(0.545)\end{array}$ \\
\hline Controls & No & Yes & No & Yes & No & Yes & No & Yes & No & Yes & No & Yes \\
\hline Observations & 800 & 800 & 791 & 791 & 801 & 801 & 1,115 & 1,115 & 1,113 & 1,113 & 1,108 & 1,108 \\
\hline $\mathrm{R}^{2}$ & 0.183 & 0.211 & 0.144 & 0.166 & 0.131 & 0.169 & 0.221 & 0.224 & 0.118 & 0.126 & 0.030 & 0.041 \\
\hline Adjusted $\mathrm{R}^{2}$ & 0.175 & 0.199 & 0.136 & 0.153 & 0.123 & 0.156 & 0.216 & 0.216 & 0.112 & 0.116 & 0.024 & 0.031 \\
\hline
\end{tabular}


Table C29: Ordinary least squares regressions on PRICE FORECAST for each participant pool (financial professionals and students) and each shock type (DOWN, STRAIGHT, and UP). POST_SHOCK is a dummy variable taking the value 1 for periods after the volatility shock (i.e., decision at $t=3$ and $\mathrm{t}=4$ ), zero otherwise, and PRE_SHOCK stands for a dummy variable taking the value 1 for periods before the shock (i.e., decision at $t=1$ and $\mathrm{t}=2$ ), zero otherwise. The interaction terms (e.g., POST_SHOCK $\times$ RETURNS) measure the combined effects of the shock phase (i.e., before or after the shock) and the respective treatment (i.e., RETURNS). PRE_SHOCK and the presentation format PRICES act as the reference categories. Controls include a participant's risk tolerance, CRT score, age, and gender. Clustered standard errors on the participant-level are in parentheses. * and ${ }^{* *}$ indicate the $5 \%$ - and the $0.5 \%$-significance levels, respectively.

\begin{tabular}{|c|c|c|c|c|c|c|c|c|c|c|c|c|}
\hline & \multicolumn{12}{|c|}{ Dependent variable: PRICE FORECAST } \\
\hline & \multicolumn{6}{|c|}{ Financial Professionals } & \multicolumn{6}{|c|}{ Students } \\
\hline & \multicolumn{2}{|c|}{ Down } & \multicolumn{2}{|c|}{ STRAIGHT } & \multicolumn{2}{|c|}{ UP } & \multicolumn{2}{|c|}{ Down } & \multicolumn{2}{|c|}{ STRAIGHT } & \multicolumn{2}{|c|}{ UP } \\
\hline & (1) & (2) & (3) & (4) & (5) & (6) & (7) & (8) & (9) & (10) & (11) & (12) \\
\hline$t=1$ & $\begin{array}{l}-0.678 \\
(0.941)\end{array}$ & $\begin{array}{l}-0.678 \\
(0.944)\end{array}$ & $\begin{array}{c}-3.576^{* *} \\
(0.811)\end{array}$ & $\begin{array}{c}-3.576^{* *} \\
(0.814)\end{array}$ & $\begin{array}{c}-0.779 \\
(1.752)\end{array}$ & $\begin{array}{c}-0.779 \\
(1.757)\end{array}$ & $\begin{array}{c}0.158 \\
(1.408)\end{array}$ & $\begin{array}{c}0.158 \\
(1.411)\end{array}$ & $\begin{array}{l}-2.293 \\
(1.384)\end{array}$ & $\begin{array}{l}-2.293 \\
(1.387)\end{array}$ & $\begin{array}{c}-0.771 \\
(1.186)\end{array}$ & $\begin{array}{c}-0.771 \\
(1.189)\end{array}$ \\
\hline$t=3$ & $\begin{array}{c}-13.641^{* *} \\
(0.855)\end{array}$ & $\begin{array}{c}-13.641^{* *} \\
(0.858)\end{array}$ & $\begin{array}{c}0.151 \\
(0.486)\end{array}$ & $\begin{array}{c}0.151 \\
(0.488)\end{array}$ & $\begin{array}{l}15.886^{* * *} \\
(1.085)\end{array}$ & $\begin{array}{l}15.886^{* *} \\
(1.089)\end{array}$ & $\begin{array}{c}-13.178^{* *} \\
(1.503)\end{array}$ & $\begin{array}{c}-13.178^{* *} \\
(1.506)\end{array}$ & $\begin{array}{c}1.901 \\
(1.272)\end{array}$ & $\begin{array}{c}1.901 \\
(1.275)\end{array}$ & $\begin{array}{l}15.478^{* *} \\
(1.311)\end{array}$ & $\begin{array}{l}15.478^{* * *} \\
(1.314)\end{array}$ \\
\hline$t=4$ & $\begin{array}{c}-14.002^{* *} \\
(0.617)\end{array}$ & $\begin{array}{c}-14.002^{* *} \\
(0.619)\end{array}$ & $\begin{array}{l}-0.897 \\
(0.576)\end{array}$ & $\begin{array}{c}-0.897 \\
(0.577)\end{array}$ & $\begin{array}{l}13.551^{* *} \\
(0.493)\end{array}$ & $\begin{array}{l}13.551^{* *} \\
(0.494)\end{array}$ & $\begin{array}{c}-14.419^{* *} \\
(1.218)\end{array}$ & $\begin{array}{c}-14.419^{* *} \\
(1.220)\end{array}$ & $\begin{array}{c}-0.831 \\
(1.237)\end{array}$ & $\begin{array}{l}-0.831 \\
(1.240)\end{array}$ & $\begin{array}{l}12.313^{* * *} \\
(0.700)\end{array}$ & $\begin{array}{l}12.313^{* *} \\
(0.702)\end{array}$ \\
\hline$t=2 \times$ RETURNS & $\begin{array}{c}0.542 \\
(1.095)\end{array}$ & $\begin{array}{c}0.630 \\
(1.227)\end{array}$ & $\begin{array}{c}2.098^{*} \\
(1.054)\end{array}$ & $\begin{array}{c}2.478 \\
(1.281)\end{array}$ & $\begin{array}{c}1.108 \\
(1.056)\end{array}$ & $\begin{array}{c}1.323 \\
(1.326)\end{array}$ & $\begin{array}{l}6.943^{* *} \\
(1.901)\end{array}$ & $\begin{array}{l}6.641^{* *} \\
(1.815)\end{array}$ & $\begin{array}{l}8.062^{* *} \\
(2.065)\end{array}$ & $\begin{array}{l}7.636^{* *} \\
(1.977)\end{array}$ & $\begin{array}{l}9.305^{\text {*** }} \\
(1.864)\end{array}$ & $\begin{array}{l}8.919^{* * *} \\
(1.759)\end{array}$ \\
\hline$t=1 \times$ RETURNS & $\begin{array}{c}2.758 \\
(1.409)\end{array}$ & $\begin{array}{c}2.846 \\
(1.546)\end{array}$ & $\begin{array}{c}1.770 \\
(1.373)\end{array}$ & $\begin{array}{c}2.150 \\
(1.572)\end{array}$ & $\begin{array}{c}0.675 \\
(2.057)\end{array}$ & $\begin{array}{c}0.890 \\
(2.259)\end{array}$ & $\begin{array}{l}8.296^{* *} \\
(1.941)\end{array}$ & $\begin{array}{l}7.995^{* *} \\
(1.897)\end{array}$ & $\begin{array}{l}6.983^{* *} \\
(1.846)\end{array}$ & $\begin{array}{c}6.557^{\text {*** }} \\
(1.789)\end{array}$ & $\begin{array}{l}7.811^{* * *} \\
(1.841)\end{array}$ & $\begin{array}{c}7.424^{* * *} \\
(1.754)\end{array}$ \\
\hline$t=3 \times$ RETURNS & $\begin{array}{l}-2.048 \\
(1.151)\end{array}$ & $\begin{array}{l}-1.960 \\
(1.224)\end{array}$ & $\begin{array}{c}0.608 \\
(1.132)\end{array}$ & $\begin{array}{c}0.988 \\
(1.331)\end{array}$ & $\begin{array}{c}1.436 \\
(1.637)\end{array}$ & $\begin{array}{c}1.651 \\
(1.814)\end{array}$ & $\begin{array}{c}-0.959 \\
(1.642)\end{array}$ & $\begin{array}{l}-1.260 \\
(1.566)\end{array}$ & $\begin{array}{l}5.594^{* *} \\
(1.973)\end{array}$ & $\begin{array}{r}5.168^{*} \\
(1.855)\end{array}$ & $\begin{array}{l}12.322^{* * *} \\
(1.965)\end{array}$ & $\begin{array}{l}11.936^{* *} \\
(1.869)\end{array}$ \\
\hline$t=4 \times$ RETURNS & $\begin{array}{l}-0.895 \\
(0.969)\end{array}$ & $\begin{array}{l}-0.808 \\
(1.074)\end{array}$ & $\begin{array}{c}0.108 \\
(1.122)\end{array}$ & $\begin{array}{c}0.488 \\
(1.314)\end{array}$ & $\begin{array}{c}2.201 \\
(1.154)\end{array}$ & $\begin{array}{c}2.417 \\
(1.409)\end{array}$ & $\begin{array}{c}2.979^{*} \\
(1.474)\end{array}$ & $\begin{array}{c}2.678 \\
(1.406)\end{array}$ & $\begin{array}{l}6.088^{* *} \\
(1.736)\end{array}$ & $\begin{array}{c}5.662^{* *} \\
(1.655)\end{array}$ & $\begin{array}{l}11.009^{* *} \\
(1.909)\end{array}$ & $\begin{array}{l}10.622^{* *} \\
(1.789)\end{array}$ \\
\hline Constant & $\begin{array}{c}100.273^{* *} \\
(1.080)\end{array}$ & $\begin{array}{c}100.809^{* *} \\
(1.645)\end{array}$ & $\begin{array}{c}100.716^{* *} \\
(1.027)\end{array}$ & $\begin{array}{c}101.009^{* *} \\
(1.812)\end{array}$ & $\begin{array}{c}100.950^{* * *} \\
(1.035)\end{array}$ & $\begin{array}{l}99.834^{* *} \\
(2.692)\end{array}$ & $\begin{array}{l}99.358^{* *} \\
(1.304)\end{array}$ & $\begin{array}{c}100.936^{* * *} \\
(6.224)\end{array}$ & $\begin{array}{l}99.599^{* * *} \\
(1.648)\end{array}$ & $\begin{array}{c}109.587^{* *} \\
(7.833)\end{array}$ & $\begin{array}{l}98.281^{* *} \\
(1.160)\end{array}$ & $\begin{array}{c}100.670^{* * *} \\
(7.553)\end{array}$ \\
\hline Controls & No & Yes & No & Yes & No & Yes & No & Yes & No & Yes & No & Yes \\
\hline Observations & 808 & 808 & 808 & 808 & 808 & 808 & 1,128 & 1,128 & 1,128 & 1,128 & 1,128 & 1,128 \\
\hline $\mathrm{R}^{2}$ & 0.468 & 0.476 & 0.037 & 0.107 & 0.355 & 0.380 & 0.281 & 0.299 & 0.050 & 0.078 & 0.267 & 0.284 \\
\hline Adjusted $\mathrm{R}^{2}$ & 0.463 & 0.468 & 0.029 & 0.094 & 0.349 & 0.371 & 0.276 & 0.291 & 0.044 & 0.068 & 0.262 & 0.276 \\
\hline
\end{tabular}


Table C30: Ordinary least squares regressions on RETURN FORECAST for each participant pool (financial professionals and students) and each shock type (DOWN, STRAIGHT, and UP). POST_SHOCK is a dummy variable taking the value 1 for periods after the volatility shock (i.e., decision at $t=3$ and $t=4$ ), zero otherwise, and PRE_SHOCK stands for a dummy variable taking the value 1 for periods before the shock (i.e., decision at $t=1$ and $\mathrm{t}=2$ ), zero otherwise. The interaction terms (e.g., POST_SHOCK $\times$ RETURNS) measure the combined effects of the shock phase (i.e., before or after the shock) and the respective treatment (i.e., RETURNS). PRE_SHOCK and the presentation format PRICES act as the reference categories. Controls include a participant's risk tolerance, CRT score, age, and gender. Clustered standard errors on the participant-level are in parentheses. ${ }^{*}$ and ${ }^{* *}$ indicate the $5 \%$ - and the $0.5 \%$-significance levels, respectively.

\begin{tabular}{|c|c|c|c|c|c|c|c|c|c|c|c|c|}
\hline & \multicolumn{12}{|c|}{ Dependent variable: RETURN FORECAST } \\
\hline & \multicolumn{6}{|c|}{ Financial Professionals } & \multicolumn{6}{|c|}{ Students } \\
\hline & \multicolumn{2}{|c|}{ DOWN } & \multicolumn{2}{|c|}{ STRAIGHT } & \multicolumn{2}{|c|}{ UP } & \multicolumn{2}{|c|}{ DOWN } & \multicolumn{2}{|c|}{ STRAIGHT } & \multicolumn{2}{|c|}{ UP } \\
\hline & (1) & (2) & (3) & (4) & (5) & (6) & (7) & (8) & (9) & (10) & (11) & (12) \\
\hline$t=1$ & $\begin{array}{r}-1.896^{*} \\
(0.939)\end{array}$ & $\begin{array}{r}-1.896^{*} \\
(0.942)\end{array}$ & $\begin{array}{c}0.192 \\
(0.838)\end{array}$ & $\begin{array}{c}0.192 \\
(0.841)\end{array}$ & $\begin{array}{c}0.571 \\
(1.789)\end{array}$ & $\begin{array}{c}0.571 \\
(1.795)\end{array}$ & $\begin{array}{l}-1.011 \\
(1.420)\end{array}$ & $\begin{array}{l}-1.011 \\
(1.423)\end{array}$ & $\begin{array}{c}1.469 \\
(1.382)\end{array}$ & $\begin{array}{c}1.469 \\
(1.385)\end{array}$ & $\begin{array}{c}0.380 \\
(1.173)\end{array}$ & $\begin{array}{c}0.380 \\
(1.176)\end{array}$ \\
\hline$t=3$ & $\begin{array}{l}5.162^{* *} \\
(0.880)\end{array}$ & $\begin{array}{l}5.162^{* * *} \\
(0.883)\end{array}$ & $\begin{array}{l}1.474^{* *} \\
(0.489)\end{array}$ & $\begin{array}{l}1.474^{* *} \\
(0.491)\end{array}$ & $\begin{array}{l}-0.073 \\
(0.800)\end{array}$ & $\begin{array}{l}-0.073 \\
(0.802)\end{array}$ & $\begin{array}{c}5.531^{* * *} \\
(1.626)\end{array}$ & $\begin{array}{l}5.531^{* * *} \\
(1.630)\end{array}$ & $\begin{array}{r}3.278^{*} \\
(1.269)\end{array}$ & $\begin{array}{l}3.278^{*} \\
(1.271)\end{array}$ & $\begin{array}{c}-0.205 \\
(1.138)\end{array}$ & $\begin{array}{l}-0.205 \\
(1.141)\end{array}$ \\
\hline$t=4$ & $\begin{array}{l}3.156^{* *} \\
(0.665)\end{array}$ & $\begin{array}{l}3.156^{* * *} \\
(0.667)\end{array}$ & $\begin{array}{l}2.112^{* *} \\
(0.559)\end{array}$ & $\begin{array}{l}2.112^{* *} \\
(0.561)\end{array}$ & $\begin{array}{l}-0.318 \\
(0.434)\end{array}$ & $\begin{array}{l}-0.318 \\
(0.436)\end{array}$ & $\begin{array}{c}2.476 \\
(1.302)\end{array}$ & $\begin{array}{c}2.476 \\
(1.305)\end{array}$ & $\begin{array}{c}2.229 \\
(1.233)\end{array}$ & $\begin{array}{c}2.229 \\
(1.236)\end{array}$ & $\begin{array}{r}-1.212^{*} \\
(0.598)\end{array}$ & $\begin{array}{r}-1.212^{*} \\
(0.600)\end{array}$ \\
\hline$t=2 \times$ RETURNS & $\begin{array}{c}0.610 \\
(1.106)\end{array}$ & $\begin{array}{c}0.681 \\
(1.247)\end{array}$ & $\begin{array}{r}2.076^{*} \\
(1.043)\end{array}$ & $\begin{array}{c}2.443 \\
(1.275)\end{array}$ & $\begin{array}{c}1.124 \\
(1.049)\end{array}$ & $\begin{array}{c}1.347 \\
(1.300)\end{array}$ & $\begin{array}{c}7.057^{* * *} \\
(1.922)\end{array}$ & $\begin{array}{l}6.709^{* * *} \\
(1.829)\end{array}$ & $\begin{array}{c}7.978^{* *} \\
(2.043)\end{array}$ & $\begin{array}{l}7.545^{* * *} \\
(1.955)\end{array}$ & $\begin{array}{l}9.260^{* *} \\
(1.851)\end{array}$ & $\begin{array}{l}8.889^{* *} \\
(1.751)\end{array}$ \\
\hline$t=1 \times$ RETURNS & $\begin{array}{c}2.477 \\
(1.382)\end{array}$ & $\begin{array}{c}2.549 \\
(1.537)\end{array}$ & $\begin{array}{c}1.820 \\
(1.411)\end{array}$ & $\begin{array}{c}2.187 \\
(1.614)\end{array}$ & $\begin{array}{c}0.568 \\
(2.084)\end{array}$ & $\begin{array}{c}0.791 \\
(2.278)\end{array}$ & $\begin{array}{l}8.033^{* *} \\
(1.905)\end{array}$ & $\begin{array}{l}7.685^{* * *} \\
(1.864)\end{array}$ & $\begin{array}{l}7.178^{* *} \\
(1.897)\end{array}$ & $\begin{array}{l}6.745^{* *} \\
(1.839)\end{array}$ & $\begin{array}{l}7.818^{* *} \\
(1.836)\end{array}$ & $\begin{array}{l}7.447^{* *} \\
(1.748)\end{array}$ \\
\hline$t=3 \times$ RETURNS & $\begin{array}{r}-2.736^{*} \\
(1.341)\end{array}$ & $\begin{array}{l}-2.664 \\
(1.426)\end{array}$ & $\begin{array}{c}0.708 \\
(1.136)\end{array}$ & $\begin{array}{c}1.075 \\
(1.339)\end{array}$ & $\begin{array}{c}1.204 \\
(1.327)\end{array}$ & $\begin{array}{c}1.426 \\
(1.512)\end{array}$ & $\begin{array}{l}-1.281 \\
(1.966)\end{array}$ & $\begin{array}{l}-1.629 \\
(1.877)\end{array}$ & $\begin{array}{l}5.572^{* *} \\
(1.960)\end{array}$ & $\begin{array}{l}5.140^{*} \\
(1.841)\end{array}$ & $\begin{array}{l}10.610^{* *} \\
(1.649)\end{array}$ & $\begin{array}{l}10.239^{* *} \\
(1.556)\end{array}$ \\
\hline$t=4 \times$ RETURNS & $\begin{array}{c}-1.374 \\
(1.147)\end{array}$ & $\begin{array}{c}-1.302 \\
(1.267)\end{array}$ & $\begin{array}{c}0.217 \\
(1.130)\end{array}$ & $\begin{array}{c}0.584 \\
(1.326)\end{array}$ & $\begin{array}{l}1.829 \\
(0.984)\end{array}$ & $\begin{array}{c}2.051 \\
(1.236)\end{array}$ & $\begin{array}{r}3.402^{*} \\
(1.735)\end{array}$ & $\begin{array}{c}3.054 \\
(1.655)\end{array}$ & $\begin{array}{c}6.145^{* *} \\
(1.748)\end{array}$ & $\begin{array}{l}5.712^{* *} \\
(1.665)\end{array}$ & $\begin{array}{c}9.578^{* *} \\
(1.662)\end{array}$ & $\begin{array}{l}9.207^{* * *} \\
(1.549)\end{array}$ \\
\hline Constant & $\begin{array}{c}1.159 \\
(1.091)\end{array}$ & $\begin{array}{c}1.158 \\
(1.633)\end{array}$ & $\begin{array}{c}-0.334 \\
(1.017)\end{array}$ & $\begin{array}{c}0.302 \\
(1.764)\end{array}$ & $\begin{array}{c}0.369 \\
(1.030)\end{array}$ & $\begin{array}{l}-0.101 \\
(2.540)\end{array}$ & $\begin{array}{c}0.224 \\
(1.313)\end{array}$ & $\begin{array}{c}3.115 \\
(6.755)\end{array}$ & $\begin{array}{l}-1.439 \\
(1.631)\end{array}$ & $\begin{array}{c}8.029 \\
(7.886)\end{array}$ & $\begin{array}{l}-2.257 \\
(1.154)\end{array}$ & $\begin{array}{c}-0.147 \\
(6.994)\end{array}$ \\
\hline Controls & No & Yes & No & Yes & No & Yes & No & Yes & No & Yes & No & Yes \\
\hline Observations & 808 & 808 & 808 & 808 & 808 & 808 & 1,128 & 1,128 & 1,128 & 1,128 & 1,128 & 1,128 \\
\hline $\mathrm{R}^{2}$ & 0.050 & 0.065 & 0.011 & 0.083 & 0.004 & 0.041 & 0.032 & 0.058 & 0.045 & 0.073 & 0.093 & 0.116 \\
\hline Adjusted $\mathrm{R}^{2}$ & 0.042 & 0.051 & 0.002 & 0.069 & -0.005 & 0.026 & 0.026 & 0.048 & 0.039 & 0.063 & 0.088 & 0.107 \\
\hline
\end{tabular}


Table C31: Ordinary least squares regressions on Optimistic minus Pessimistic Forecasts for each participant pool (financial professionals and students) and each shock type (DOWN, STRAIGHT, and UP). POST_SHOCK is a dummy variable taking the value 1 for periods after the volatility shock (i.e., decision at $t=3$ and $\mathrm{t}=4$ ), zero otherwise, and PRE_SHOCK stands for a dummy variable taking the value 1 for periods before the shock (i.e., decision at $t=1$ and $\mathrm{t}=2$ ), zero otherwise. The interaction terms (e.g., POST_SHOCK $\times$ RETURNS) measure the combined effects of the shock phase (i.e., before or after the shock) and the respective treatment (i.e., RETURNS). PRE_SHOCK and the presentation format PRICES act as the reference categories. Controls include a participant's risk tolerance, CRT score, age, and gender. Clustered standard errors on the participant-level are in parentheses. ${ }^{*}$ and ${ }^{* *}$ indicate the $5 \%$ - and the $0.5 \%$-significance levels, respectively.

\begin{tabular}{|c|c|c|c|c|c|c|c|c|c|c|c|c|}
\hline & \multicolumn{12}{|c|}{ Dependent variable: Optimistic minus Pessimistic Forecast } \\
\hline & \multicolumn{6}{|c|}{ Financial Professionals } & \multicolumn{6}{|c|}{ Students } \\
\hline & \multicolumn{2}{|c|}{ Down } & \multicolumn{2}{|c|}{ STRAIGHT } & \multicolumn{2}{|c|}{ UP } & \multicolumn{2}{|c|}{ Down } & \multicolumn{2}{|c|}{ STRAIGHT } & \multicolumn{2}{|c|}{ UP } \\
\hline & (1) & (2) & (3) & (4) & (5) & (6) & (7) & (8) & (9) & (10) & (11) & $(12)$ \\
\hline$t=1$ & $\begin{array}{c}0.241 \\
(0.483)\end{array}$ & $\begin{array}{c}0.241 \\
(0.484)\end{array}$ & $\begin{array}{c}0.482 \\
(0.549)\end{array}$ & $\begin{array}{c}0.482 \\
(0.551)\end{array}$ & $\begin{array}{c}0.684 \\
(0.422)\end{array}$ & $\begin{array}{c}0.684 \\
(0.424)\end{array}$ & $\begin{array}{l}11.628 \\
(9.736)\end{array}$ & $\begin{array}{l}11.628 \\
(9.757)\end{array}$ & $\begin{array}{c}1.387 \\
(0.903)\end{array}$ & $\begin{array}{l}1.387 \\
(0.905)\end{array}$ & $\begin{array}{c}-0.061 \\
(0.684)\end{array}$ & $\begin{array}{l}-0.061 \\
(0.686)\end{array}$ \\
\hline$t=3$ & $\begin{array}{l}9.837^{* *} \\
(0.864)\end{array}$ & $\begin{array}{l}9.837^{\text {*** }} \\
(0.867)\end{array}$ & $\begin{array}{l}3.951^{* *} \\
(0.830)\end{array}$ & $\begin{array}{l}3.951^{* *} \\
(0.832)\end{array}$ & $\begin{array}{l}5.057^{\text {k* }} \\
(0.912)\end{array}$ & $\begin{array}{l}5.057^{* *} \\
(0.915)\end{array}$ & $\begin{array}{l}12.815^{* *} \\
(1.304)\end{array}$ & $\begin{array}{l}12.815^{* *} \\
(1.307)\end{array}$ & $\begin{array}{l}6.263^{* *} \\
(0.739)\end{array}$ & $\begin{array}{l}6.263^{* *} \\
(0.741)\end{array}$ & $\begin{array}{l}4.036^{* *} \\
(1.031)\end{array}$ & $\begin{array}{l}4.036^{* * *} \\
(1.033)\end{array}$ \\
\hline$t=4$ & $\begin{array}{l}7.211^{* *} \\
(0.837)\end{array}$ & $\begin{array}{l}7.211^{* *} \\
(0.840)\end{array}$ & $\begin{array}{c}2.179^{*} \\
(0.841)\end{array}$ & $\begin{array}{c}2.179^{*} \\
(0.844)\end{array}$ & $\begin{array}{l}3.411^{* * *} \\
(0.608)\end{array}$ & $\begin{array}{l}3.411^{* *} \\
(0.610)\end{array}$ & $\begin{array}{l}7.365^{* *} \\
(0.856)\end{array}$ & $\begin{array}{l}7.365^{* *} \\
(0.858)\end{array}$ & $\begin{array}{l}3.128^{* *} \\
(0.846)\end{array}$ & $\begin{array}{l}3.128^{* *} \\
(0.848)\end{array}$ & $\begin{array}{c}2.062^{*} \\
(0.841)\end{array}$ & $\begin{array}{r}2.062^{*} \\
(0.843)\end{array}$ \\
\hline$t=2 \times$ RETURNS & $\begin{array}{c}-1.231 \\
(1.664)\end{array}$ & $\begin{array}{c}-1.216 \\
(1.651)\end{array}$ & $\begin{array}{c}-1.868 \\
(1.831)\end{array}$ & $\begin{array}{l}-1.885 \\
(1.818)\end{array}$ & $\begin{array}{l}-2.044 \\
(1.724)\end{array}$ & $\begin{array}{c}-2.076 \\
(1.748)\end{array}$ & $\begin{array}{c}1.204 \\
(1.729)\end{array}$ & $\begin{array}{c}1.207 \\
(1.671)\end{array}$ & $\begin{array}{l}-0.696 \\
(1.436)\end{array}$ & $\begin{array}{c}-0.979 \\
(1.421)\end{array}$ & $\begin{array}{c}-1.445 \\
(1.996)\end{array}$ & $\begin{array}{l}-1.691 \\
(2.011)\end{array}$ \\
\hline$t=1 \times$ RETURNS & $\begin{array}{c}-1.737 \\
(1.589)\end{array}$ & $\begin{array}{c}-1.722 \\
(1.575)\end{array}$ & $\begin{array}{c}-2.282 \\
(1.929)\end{array}$ & $\begin{array}{l}-2.299 \\
(1.933)\end{array}$ & $\begin{array}{c}-2.289 \\
(1.843)\end{array}$ & $\begin{array}{c}-2.321 \\
(1.867)\end{array}$ & $\begin{array}{c}-10.875 \\
(10.708)\end{array}$ & $\begin{array}{c}-10.872 \\
(10.512)\end{array}$ & $\begin{array}{c}-1.176 \\
(1.677)\end{array}$ & $\begin{array}{c}-1.458 \\
(1.667)\end{array}$ & $\begin{array}{c}-1.572 \\
(1.686)\end{array}$ & $\begin{array}{c}-1.818 \\
(1.692)\end{array}$ \\
\hline$t=3 \times$ RETURNS & $\begin{array}{c}-3.338 \\
(2.179)\end{array}$ & $\begin{array}{c}-3.323 \\
(2.147)\end{array}$ & $\begin{array}{c}-3.652 \\
(1.894)\end{array}$ & $\begin{array}{c}-3.668^{*} \\
(1.867)\end{array}$ & $\begin{array}{c}-3.784^{*} \\
(1.788)\end{array}$ & $\begin{array}{c}-3.816^{*} \\
(1.811)\end{array}$ & $\begin{array}{c}-6.537^{* * *} \\
(2.124)\end{array}$ & $\begin{array}{l}-6.535^{* *} \\
(2.120)\end{array}$ & $\begin{array}{l}-5.427^{* * *} \\
(1.655)\end{array}$ & $\begin{array}{c}-5.709^{* *} \\
(1.651)\end{array}$ & $\begin{array}{c}-1.603 \\
(1.563)\end{array}$ & $\begin{array}{c}-1.849 \\
(1.565)\end{array}$ \\
\hline$t=4 \times$ RETURNS & $\begin{array}{c}-3.965 \\
(2.093)\end{array}$ & $\begin{array}{c}-3.950 \\
(2.070)\end{array}$ & $\begin{array}{l}-4.366^{*} \\
(1.736)\end{array}$ & $\begin{array}{c}-4.383^{*} \\
(1.741)\end{array}$ & $\begin{array}{c}-3.912^{*} \\
(1.694)\end{array}$ & $\begin{array}{c}-3.944^{*} \\
(1.736)\end{array}$ & $\begin{array}{c}-4.722^{* *} \\
(1.628)\end{array}$ & $\begin{array}{c}-4.720^{* *} \\
(1.657)\end{array}$ & $\begin{array}{l}-2.204 \\
(2.030)\end{array}$ & $\begin{array}{l}-2.486 \\
(2.024)\end{array}$ & $\begin{array}{c}-3.056^{*} \\
(1.544)\end{array}$ & $\begin{array}{c}-3.302^{*} \\
(1.545)\end{array}$ \\
\hline Constant & $\begin{array}{l}11.689^{* *} \\
(1.427)\end{array}$ & $\begin{array}{c}2.826 \\
(5.278)\end{array}$ & $\begin{array}{l}13.215^{* *} \\
(1.585)\end{array}$ & $\begin{array}{l}6.484 \\
(5.618)\end{array}$ & $\begin{array}{l}12.148^{\text {*** }} \\
(1.527)\end{array}$ & $\begin{array}{c}5.986 \\
(4.782)\end{array}$ & $\begin{array}{l}10.948^{* *} \\
(1.180)\end{array}$ & $\begin{array}{c}10.229 \\
(10.123)\end{array}$ & $\begin{array}{l}11.541^{* * *} \\
(1.073)\end{array}$ & $\begin{array}{l}19.648^{* *} \\
(5.427)\end{array}$ & $\begin{array}{l}12.499^{* *} \\
(1.631)\end{array}$ & $\begin{array}{l}16.123^{*} \\
(6.955)\end{array}$ \\
\hline Controls & No & Yes & No & Yes & No & Yes & No & Yes & No & Yes & No & Yes \\
\hline Observations & 808 & 808 & 808 & 808 & 808 & 808 & 1,128 & 1,128 & 1,128 & 1,128 & 1,128 & 1,128 \\
\hline $\mathrm{R}^{2}$ & 0.085 & 0.119 & 0.023 & 0.057 & 0.033 & 0.058 & 0.011 & 0.019 & 0.020 & 0.033 & 0.018 & 0.029 \\
\hline Adjusted $\mathrm{R}^{2}$ & 0.077 & 0.106 & 0.015 & 0.043 & 0.024 & 0.044 & 0.005 & 0.008 & 0.014 & 0.023 & 0.012 & 0.019 \\
\hline
\end{tabular}


Table C32: WAVE 2. Ordinary least squares regressions on INVESTMENT, RECOMMENDATION, and SATISFACTION, for each participant pool (financial professionals and students) and each presentation format (RETURNS Or PRICES). POST_SHOCK is a dummy variable taking the value 1 for periods after the volatility shock (i.e., $t=3$ and $t=4$ ), zero otherwise, and PRE_SHOCK stands for a dummy variable taking the value 1 for periods before the shock (i.e., $t=1$ and $t=2$ ), zero otherwise. The interaction terms (e.g., POST_SHOCK $\times$ UP) measure the combined effects of the shock phase (i.e., before or after the shock) and the respective treatment (i.e., UP or DOWN). All specifications are run with a participant's risk attitude, CRT score, age, and gender as control variables. Clustered standard errors at the participant-level are in parentheses. ${ }^{*}$ and ${ }^{* *}$ indicate the $5 \%$ - and $0.5 \%$-significance levels, respectively.

\begin{tabular}{|c|c|c|c|c|c|c|}
\hline \multirow[b]{2}{*}{ Finance Professionals } & \multicolumn{2}{|c|}{ Investment } & \multicolumn{2}{|c|}{ Recommendation } & \multicolumn{2}{|c|}{ Satisfaction } \\
\hline & $\begin{array}{l}\text { Prices } \\
\text { (1) }\end{array}$ & $\begin{array}{c}\text { Returns } \\
\text { (2) }\end{array}$ & $\begin{array}{l}\text { Prices } \\
\text { (3) }\end{array}$ & $\begin{array}{c}\text { Returns } \\
\text { (4) }\end{array}$ & $\begin{array}{l}\text { Prices } \\
(5)\end{array}$ & $\begin{array}{c}\text { Returns } \\
\text { (6) }\end{array}$ \\
\hline POST_SHOCK & $\begin{array}{c}-1.612 \\
(2.323)\end{array}$ & $\begin{array}{c}-1.765 \\
(2.561)\end{array}$ & $\begin{array}{r}-0.177^{*} \\
(0.064)\end{array}$ & $\begin{array}{r}-0.236^{*} \\
(0.108)\end{array}$ & $\begin{array}{c}-0.627^{* *} \\
(0.123)\end{array}$ & $\begin{array}{c}-0.815^{\text {** }} \\
(0.140)\end{array}$ \\
\hline PRE_SHOCK $\times$ DOWN & $\begin{array}{c}-2.043 \\
(2.638)\end{array}$ & $\begin{array}{c}0.398 \\
(2.402)\end{array}$ & $\begin{array}{c}-0.065 \\
(0.055)\end{array}$ & $\begin{array}{c}-0.064 \\
(0.091)\end{array}$ & $\begin{array}{c}-0.084 \\
(0.107)\end{array}$ & $\begin{array}{r}-0.272^{*} \\
(0.111)\end{array}$ \\
\hline POST_SHOCK $\times$ DOWN & $\begin{array}{c}9.664^{* *} \\
(2.847)\end{array}$ & $\begin{array}{c}8.444^{* *} \\
(2.818)\end{array}$ & $\begin{array}{c}0.310^{* *} \\
(0.099)\end{array}$ & $\begin{array}{c}0.336^{*} \\
(0.124)\end{array}$ & $\begin{array}{c}-0.501^{* *} \\
(0.122)\end{array}$ & $\begin{array}{r}-0.354^{*} \\
(0.149)\end{array}$ \\
\hline PRE_SHOCK $\times$ UP & $\begin{array}{c}2.011 \\
(2.116)\end{array}$ & $\begin{array}{c}-0.670 \\
(2.217)\end{array}$ & $\begin{array}{c}-0.056 \\
(0.056)\end{array}$ & $\begin{array}{c}0.027 \\
(0.089)\end{array}$ & $\begin{array}{c}-0.050 \\
(0.112)\end{array}$ & $\begin{array}{r}-0.126 \\
(0.117)\end{array}$ \\
\hline POST_SHOCK $\times$ UP & $\begin{array}{c}-3.804 \\
(2.485)\end{array}$ & $\begin{array}{c}-4.306 \\
(2.498)\end{array}$ & $\begin{array}{c}-0.138 \\
(0.086)\end{array}$ & $\begin{array}{c}0.027 \\
(0.105)\end{array}$ & $\begin{array}{c}1.388^{* *} \\
(0.132)\end{array}$ & $\begin{array}{c}1.334^{* *} \\
(0.153)\end{array}$ \\
\hline Constant & $\begin{array}{c}13.183 \\
(15.785)\end{array}$ & $\begin{array}{c}25.857 \\
(25.798)\end{array}$ & $\begin{array}{c}3.366^{* *} \\
(0.215)\end{array}$ & $\begin{array}{c}3.154^{* *} \\
(0.429)\end{array}$ & $\begin{array}{c}0.679 \\
(0.438)\end{array}$ & $\begin{array}{c}-0.830 \\
(0.529)\end{array}$ \\
\hline Observations & 695 & 660 & 695 & 660 & 686 & 653 \\
\hline $\mathrm{R}^{2}$ & 0.236 & 0.292 & 0.107 & 0.028 & 0.193 & 0.137 \\
\hline Adjusted $\mathrm{R}^{2}$ & 0.224 & 0.281 & 0.094 & 0.013 & 0.181 & 0.124 \\
\hline Students & (7) & (8) & (9) & (10) & (11) & (12) \\
\hline POST_SHOCK & $\begin{array}{c}-0.223 \\
(1.529)\end{array}$ & $\begin{array}{c}0.619 \\
(1.676)\end{array}$ & $\begin{array}{c}-0.086 \\
(0.049)\end{array}$ & $\begin{array}{c}-0.059 \\
(0.072)\end{array}$ & $\begin{array}{c}-0.667^{* *} \\
(0.092)\end{array}$ & $\begin{array}{c}-0.926^{* *} \\
(0.092)\end{array}$ \\
\hline PRE_SHOCK $\times$ DOWN & $\begin{array}{c}0.111 \\
(1.801)\end{array}$ & $\begin{array}{c}1.077 \\
(1.799)\end{array}$ & $\begin{array}{c}-0.047 \\
(0.061)\end{array}$ & $\begin{array}{c}0.031 \\
(0.070)\end{array}$ & $\begin{array}{r}-0.194^{*} \\
(0.080)\end{array}$ & $\begin{array}{c}-0.306^{* *} \\
(0.089)\end{array}$ \\
\hline POST_SHOCK $\times$ DOWN & $\begin{array}{c}3.383 \\
(2.178)\end{array}$ & $\begin{array}{c}0.208 \\
(1.613)\end{array}$ & $\begin{array}{c}0.232^{*} \\
(0.084)\end{array}$ & $\begin{array}{c}-0.027 \\
(0.078)\end{array}$ & $\begin{array}{c}-0.647^{* *} \\
(0.110)\end{array}$ & $\begin{array}{c}-0.079 \\
(0.093)\end{array}$ \\
\hline PRE_SHOCK $\times$ UP & $\begin{array}{c}-0.742 \\
(1.634)\end{array}$ & $\begin{array}{c}-0.734 \\
(1.778)\end{array}$ & $\begin{array}{c}-0.057 \\
(0.058)\end{array}$ & $\begin{array}{c}0.036 \\
(0.066)\end{array}$ & $\begin{array}{c}-0.081 \\
(0.087)\end{array}$ & $\begin{array}{c}-0.176 \\
(0.092)\end{array}$ \\
\hline POST_SHOCK $\times$ UP & $\begin{array}{c}-2.970 \\
(1.988)\end{array}$ & $\begin{array}{c}-1.495 \\
(2.038)\end{array}$ & $\begin{array}{c}-0.250^{* *} \\
(0.070)\end{array}$ & $\begin{array}{c}0.095 \\
(0.083)\end{array}$ & $\begin{array}{c}1.874^{* *} \\
(0.115)\end{array}$ & $\begin{array}{c}1.599^{* *} \\
(0.108)\end{array}$ \\
\hline Constant & $\begin{array}{c}3.447 \\
(26.306)\end{array}$ & $\begin{array}{c}2.019 \\
(15.953)\end{array}$ & $\begin{array}{c}3.131^{* *} \\
(0.194)\end{array}$ & $\begin{array}{c}2.747^{* *} \\
(0.301)\end{array}$ & $\begin{array}{c}0.076 \\
(0.362)\end{array}$ & $\begin{array}{c}-0.310 \\
(0.385)\end{array}$ \\
\hline Observations & 1,248 & 1,321 & 1,248 & 1,321 & 1,246 & 1,315 \\
\hline $\mathrm{R}^{2}$ & 0.166 & 0.215 & 0.051 & 0.043 & 0.217 & 0.117 \\
\hline Adjusted $\mathrm{R}^{2}$ & 0.159 & 0.209 & 0.043 & 0.035 & 0.210 & 0.111 \\
\hline
\end{tabular}


Table C33: WAVE 2. Ordinary least squares regressions on RISK PERCEPTION, PRICE FORECAST, and RETURN FORECAST, for each participant pool (financial professionals and students) and each presentation format (RETURNS or PRICES). POST_SHOCK is a dummy variable taking the value 1 for periods after the volatility shock (i.e., $t=3$ and $t=4$ ), zero otherwise, and PRE_SHOCK stands for a dummy variable taking the value 1 for periods before the shock (i.e., $t=1$ and $t=2$ ), zero otherwise. The interaction terms (e.g., POST_SHOCK $\times$ UP) measure the combined effects of the shock phase (i.e., before or after the shock) and the respective treatment (i.e., UP or DOWN). All specifications are run with a participant's risk attitude, CRT score, age, and gender as control variables. Clustered standard errors at the participant-level are in parentheses. ${ }^{*}$ and ${ }^{* *}$ indicate the $5 \%$ - and $0.5 \%$-significance levels, respectively.

\begin{tabular}{|c|c|c|c|c|c|c|}
\hline \multirow[b]{2}{*}{ Finance Professionals } & \multicolumn{2}{|c|}{ Risk perception } & \multicolumn{2}{|c|}{ Price forecast } & \multicolumn{2}{|c|}{ Return forecast } \\
\hline & $\begin{array}{l}\text { Prices } \\
\text { (1) }\end{array}$ & $\begin{array}{l}\text { Returns } \\
\text { (2) }\end{array}$ & $\begin{array}{l}\text { Prices } \\
\text { (3) }\end{array}$ & $\begin{array}{l}\text { Returns } \\
\text { (4) }\end{array}$ & $\begin{array}{l}\text { Prices } \\
(5)\end{array}$ & $\begin{array}{l}\text { Returns } \\
\text { (6) }\end{array}$ \\
\hline POST_SHOCK & $\begin{array}{c}0.934^{* *} \\
(0.144)\end{array}$ & $\begin{array}{c}0.271^{*} \\
(0.122)\end{array}$ & $\begin{array}{c}0.838 \\
(0.833)\end{array}$ & $\begin{array}{c}-0.363 \\
(0.333)\end{array}$ & $\begin{array}{c}1.312 \\
(0.853)\end{array}$ & $\begin{array}{c}-0.134 \\
(0.285)\end{array}$ \\
\hline PRE_SHOCK $\times$ DOWN & $\begin{array}{c}0.030 \\
(0.129)\end{array}$ & $\begin{array}{r}-0.134 \\
(0.108)\end{array}$ & $\begin{array}{c}0.382 \\
(0.647)\end{array}$ & $\begin{array}{c}0.720 \\
(0.563)\end{array}$ & $\begin{array}{c}-0.387 \\
(0.644)\end{array}$ & $\begin{array}{c}0.030 \\
(0.567)\end{array}$ \\
\hline POST_SHOCK $\times$ DOWN & $\begin{array}{c}0.175 \\
(0.115)\end{array}$ & $\begin{array}{c}0.160 \\
(0.111)\end{array}$ & $\begin{array}{c}-13.180^{* *} \\
(1.051)\end{array}$ & $\begin{array}{c}-14.958^{* *} \\
(0.636)\end{array}$ & $\begin{array}{c}3.695^{* *} \\
(1.028)\end{array}$ & $\begin{array}{c}2.440^{* *} \\
(0.787)\end{array}$ \\
\hline PRE_SHOCK $\times$ UP & $\begin{array}{c}0.125 \\
(0.143)\end{array}$ & $\begin{array}{c}0.055 \\
(0.083)\end{array}$ & $\begin{array}{c}2.628 \\
(2.497)\end{array}$ & $\begin{array}{c}0.341 \\
(0.406)\end{array}$ & $\begin{array}{c}1.868 \\
(2.540)\end{array}$ & $\begin{array}{c}-0.434 \\
(0.397)\end{array}$ \\
\hline POST_SHOCK $\times$ UP & $\begin{array}{c}-0.103 \\
(0.127)\end{array}$ & $\begin{array}{c}0.120 \\
(0.084)\end{array}$ & $\begin{array}{l}13.655^{* *} \\
(1.019)\end{array}$ & $\begin{array}{l}16.218^{* *} \\
(0.499)\end{array}$ & $\begin{array}{c}-2.934^{* *} \\
(0.885)\end{array}$ & $\begin{array}{c}-0.595 \\
(0.441)\end{array}$ \\
\hline Constant & $\begin{array}{c}3.307^{* *} \\
(0.606)\end{array}$ & $\begin{array}{c}5.752^{* *} \\
(0.961)\end{array}$ & $\begin{array}{l}90.113^{* *} \\
(9.119)\end{array}$ & $\begin{array}{c}102.148^{* *} \\
(3.060)\end{array}$ & $\begin{array}{r}-10.389 \\
(9.154)\end{array}$ & $\begin{array}{c}3.005 \\
(3.189)\end{array}$ \\
\hline Observations & 676 & 651 & 695 & 660 & 695 & 660 \\
\hline $\begin{array}{l}\mathrm{R}^{2} \\
\text { Adjusted } \mathrm{R}^{2}\end{array}$ & $\begin{array}{l}0.162 \\
0.149\end{array}$ & $\begin{array}{l}0.075 \\
0.060\end{array}$ & $\begin{array}{l}0.222 \\
0.211\end{array}$ & $\begin{array}{l}0.719 \\
0.714\end{array}$ & $\begin{array}{l}0.071 \\
0.057\end{array}$ & $\begin{array}{l}0.097 \\
0.083\end{array}$ \\
\hline Students & (7) & (8) & (9) & (10) & (11) & (12) \\
\hline POST_SHOCK & $\begin{array}{c}0.877^{* *} \\
(0.104)\end{array}$ & $\begin{array}{c}0.373^{* *} \\
(0.087)\end{array}$ & $\begin{array}{c}1.018 \\
(0.891)\end{array}$ & $\begin{array}{c}-0.970 \\
(0.546)\end{array}$ & $\begin{array}{c}1.159 \\
(0.907)\end{array}$ & $\begin{array}{r}-0.925 \\
(0.535)\end{array}$ \\
\hline PRE_SHOCK $\times$ DOWN & $\begin{array}{c}0.085 \\
(0.131)\end{array}$ & $\begin{array}{c}0.080 \\
(0.110)\end{array}$ & $\begin{array}{c}-0.097 \\
(1.187)\end{array}$ & $\begin{array}{c}0.612 \\
(1.221)\end{array}$ & $\begin{array}{c}-0.732 \\
(1.185)\end{array}$ & $\begin{array}{r}-0.149 \\
(1.225)\end{array}$ \\
\hline POST_SHOCK $\times$ DOWN & $\begin{array}{c}0.523^{* *} \\
(0.126)\end{array}$ & $\begin{array}{c}0.400^{* *} \\
(0.090)\end{array}$ & $\begin{array}{c}-13.871^{* *} \\
(0.991)\end{array}$ & $\begin{array}{c}-18.178^{* *} \\
(1.044)\end{array}$ & $\begin{array}{c}3.410^{* *} \\
(0.998)\end{array}$ & $\begin{array}{c}-0.242 \\
(1.081)\end{array}$ \\
\hline PRE_SHOCK $\times$ UP & $\begin{array}{c}0.215 \\
(0.112)\end{array}$ & $\begin{array}{c}0.206 \\
(0.117)\end{array}$ & $\begin{array}{c}-0.525 \\
(1.000)\end{array}$ & $\begin{array}{c}-0.247 \\
(1.378)\end{array}$ & $\begin{array}{c}-1.391 \\
(1.025)\end{array}$ & $\begin{array}{c}-1.199 \\
(1.367)\end{array}$ \\
\hline POST_SHOCK $\times$ UP & $\begin{array}{c}-0.339^{* *} \\
(0.110)\end{array}$ & $\begin{array}{c}-0.119 \\
(0.105)\end{array}$ & $\begin{array}{l}13.923^{* *} \\
(1.447)\end{array}$ & $\begin{array}{l}18.660^{* *} \\
(1.045)\end{array}$ & $\begin{array}{c}-2.389 \\
(1.361)\end{array}$ & $\begin{array}{c}0.626 \\
(0.937)\end{array}$ \\
\hline Constant & $\begin{array}{c}3.997^{* *} \\
(0.702)\end{array}$ & $\begin{array}{l}5.660^{* *} \\
(0.732)\end{array}$ & $\begin{array}{l}118.027^{* *} \\
(24.873)\end{array}$ & $\begin{array}{c}98.055^{* *} \\
(15.157)\end{array}$ & $\begin{array}{c}18.433 \\
(25.185)\end{array}$ & $\begin{array}{c}0.004 \\
(14.940)\end{array}$ \\
\hline Observations & 1,222 & 1,309 & 1,248 & 1,321 & 1,248 & 1,321 \\
\hline $\mathrm{R}^{2}$ & 0.129 & 0.090 & 0.174 & 0.256 & 0.062 & 0.031 \\
\hline Adjusted $\mathrm{R}^{2}$ & 0.122 & 0.083 & 0.168 & 0.250 & 0.054 & 0.024 \\
\hline
\end{tabular}

